UNIVERSIDADE DE SÃO PAULO

FACULDADE DE FILOSOFIA, LETRAS E CIÊNCIAS HUMANAS

DEPARTAMENTO DE LETRAS CLÁSSICAS E VERNÁCULAS

PROGRAMA DE ESTUDOS COMPARADOS DE LITERATURAS DE LÍNGUA PORTUGUESA

Edison de Abreu Rodrigues

O fogão, o quintal e a escrivaninha: estudo comparativo entre a literatura de Cora Coralina e a de Manoel de Barros 
Edison de Abreu Rodrigues

\section{O fogão, o quintal e a escrivaninha: estudo comparativo entre a literatura de Cora Coralina e a de Manoel de Barros}

\section{Versão Revisada}

Tese apresentada à Banca Examinadora da Faculdade de Filosofia, Letras e Ciências Humanas da Universidade de São Paulo, como requisito parcial para obtenção do título de DOUTOR em Letras.

Área de concentração: Literatura infantil e juvenil.

Orientador: Prof. Dr. José Nicolau Gregorin Filho. 
Autorizo a reprodução e divulgação total ou parcial deste trabalho, por qualquer meio convencional ou eletrônico, para fins de estudo e pesquisa, desde que citada a fonte.

Catalogação na Publicação

Serviço de Biblioteca e Documentação

Faculdade de Filosofia, Letras e Ciências Humanas da Universidade de São Paulo

R696f

Rodrigues, Edison de Abreu

O fogão, o quintal e a escrivaninha: estudo comparativo entre a literatura de Cora Coralina e a de Manoel de Barros / Edison de Abreu Rodrigues; orientador José Nicolau Gregorin Filho. - São Paulo, 2020.

$200 \mathrm{f}$.

Tese (Doutorado)- Faculdade de Filosofia, Letras e Ciências Humanas da Universidade de São Paulo. Departamento de Letras Clássicas e Vernáculas. Área de concentração: Estudos Comparados de Literaturas de Língua Portuguesa.

1. Cora Coralina - Manoel de Barros - infância poesia - cultura. I. Gregorin Filho, José Nicolau, orient. II. Título. 


\section{ENTREGA DO EXEMPLAR CORRIGIDO DA DISSERTAÇÃO/TESE \\ Termo de Ciência e Concordância do (a) orientador (a)}

Nome do (a) aluno (a): Edison de Abreu Rodrigues

Data da defesa: 13/03/2020

Nome do Prof. (a) orientador (a): José Nicolau Gregorin Filho

Nos termos da legislação vigente, declaro ESTAR CIENTE do conteúdo deste EXEMPLAR CORRIGIDO elaborado em atenção às sugestões dos membros da comissão Julgadora na sessão de defesa do trabalho, manifestando-me plenamente favorável ao seu encaminhamento e publicação no Portal Digital de Teses da USP.

São Paulo, 15/05/2020

Jose Nicolau Gregorin Filho

(Assinatura do (a) orientador (a)

Foi aprovada a autorização de Ciência e Concordância da Versão corrigida via e-mail no dia 13/05/2020. 
RODRIGUES, Edison de Abreu. O fogão, o quintal e a escrivaninha: estudo comparativo entre a literatura de Cora Coralina e a de Manoel de Barros. Tese de Doutorado. Programa de Estudos Comparados de Literaturas de Língua Portuguesa. Universidade de São Paulo, SP, Brasil, p. 200. 2020.

Aprovado em: 13 / 03 / 2020

\section{Banca examinadora}

Prof. Dr. José Nicolau Gregorin Filho

Instituição: Universidade de São Paulo

Julgamento: Aprovado

Prof ${ }^{\text {a }}$. Dr ${ }^{\text {a }}$. Maria Aparecida Junqueira

Instituição: Pontifícia Universidade Católica de São Paulo

Julgamento: Aprovado

Prof ${ }^{a}$. Dr ${ }^{a}$. Nágila Euclides da Silva Polido

Instituição: Secretaria Municipal de Educação de São Paulo

Julgamento: Aprovado

Prof. Dr. Ricardo lannace

Instituição: Universidade de São Paulo

Julgamento: Aprovado 


\section{DEDICATÓRIA}

À minha esposa, Luciana, aos meus filhos, Bernardo e Benício, com amor, admiração e gratidão por sua compreensão, carinho, presença e incansável apoio ao longo do período de elaboração deste trabalho.

À minha mãe, Raquel, à minha irmã, Maria do Carmo, que, com amor, compreenderam minhas faltas, em todos os sentidos.

Ao meu pai, Joaquim (in memoriam), onde quer que ele esteja, gostaria de abraçá-lo e poder lhe dizer que este trabalho é por ele e para ele. 


\section{AGRADECIMENTOS}

São tantos a agradecer que o medo de esquecer algum nome certamente fundamental para a realização deste misto de sonho e pesquisa toma conta de mim, assim humildemente ouso fazer minhas as palavras de Cora Coralina em seu poema "Oração de Aninha" (p. 197-198) publicado no livro Vintém de cobre: meias confissões de Aninha:

Pela manhã, abre a janela de tua casa

e faze a prece de gratidão.

Levanta teu coração para o Alto.

É a hora solene da oração.

(...)

"Quem chama por Deus

não cansa nunca"

e Ele se fará presente.

Muito pedimos e pouco agradecemos.

Sentimento raro de se encontrar no coração

humano: Gratidão.

Muitos se ufanam:

"Não devo nada a ninguém".

Engano: devemos muito a todos. (...)

Em regra, aquele que acredita

nada dever a alguém,

também nada faz por ninguém.

É o egoísta: macula

os bens da vida, a alegria de viver.

Já a linguagem dos humildes:

"Abaixo de Deus devo tudo o que tenho

a fulano". É sempre este o homem

solidário, feito para ajudar

e com ele está a benevolência,

capacidade de servir, e a paz social,

- Espírito de Deus está na sua casa

E sua tulha estará sempre derramando. 
Palavra poética tem que chegar ao grau de brinquedo para ser séria. Manoel de Barros in Livro sobre nada, página 71, 1996. 


\section{RESUMO}

O objetivo do presente trabalho é apresentar um estudo comparativo que põe em diálogo poemas de Cora Coralina, reeditados como obras de literatura infantil, com poemas que figuram nas obras infantis de Manoel de Barros, com o intuito de verificar representações literárias de experiências infantis construídas por ambos, e - quanto tais construções podem representar poeticamente vivências que reverberam elementos culturais e identitários dos interiores do país. Além disso, pretende-se também demonstrar o quanto as especificidades presentes nos poemas de ambos dialogam no que concerne à representação poética, cultural e identitária de experiências infantis vividas nos interiores de Goiás e Mato Grosso e, por fim, verificar em que medida tais textos devem ser levados à sala de aula de todo país para que os alunos possam entrar, simultaneamente, em contato com a poesia de Cora Coralina e Manoel de Barros, experimentando esteticamente representações culturais e identitárias do interior do Brasil. Para tanto, a metodologia buscou a fundamentação nos estudos comparatistas, apresentando representações estéticas nesse diálogo entre as obras, bem como das representações contidas nos textos literários relacionados universo cultural dos quais esses textos surgiram e com os quais procuram dialogar. Tal trabalho se justifica pela inédita aproximação entre a literatura desses dois emblemáticos nomes da poesia brasileira, bem como em razão do pequeno número de pesquisas acadêmicas realizadas em nível de pósgraduação envolvendo especialmente a obra de Cora Coralina nas universidades brasileiras.

PALAVRAS-CHAVE: Cora Coralina - Manoel de Barros - infância - poesia cultura 


\begin{abstract}
This research aims to presente a comparative study that promotes the dialogue between the poems of Cora Coralina, republished as children's literature, to Manoel de Barros children's poems, in order to verify the literary representations of infant experiences constructed by booth authors, and how much these constructions can poetically represent the livingness that reverberate cultural and identity elements from inland áreas of the country. Furthermore this study intends to demonstrate how the specificities present in their poems dialogue when it comes to the poetic, cultural and identity representation of childhood experiences lived in the countryside of Goiás and Mato Grosso and, to top it off, verify in which means those texts may be used in the regular classes in the whole country so that students can be in contact simultaneously with both authors'poetry, Cora Coralina e Manoel de Barros, experiencing aesthetically cultural and identity representations from the countyside of Brazil. To reach that, the methodology was based in comparative studies, showing the aesthetic representations in the dialogue between the literary works, as well as the representations found in the literary texts related to the cultural universe from where these texts emerged and which one those texts try dialogue with. This research justified by the original approximation between these two emblematic names from Brazilian poetry, as weel as because of the small number of academic researches in the post-graduation level, specially dedicated to Cora Coralina in Brazilian universities.
\end{abstract}

KEY-WORDS: Cora Coralina - Manoel de Barros - childhood - poetry - culture 


\section{LISTA DE ILUSTRAÇÕES}

Figura 1: A escrivaninha de Cora Coralina ……….............................................. 20

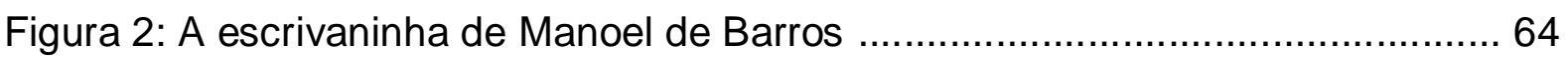

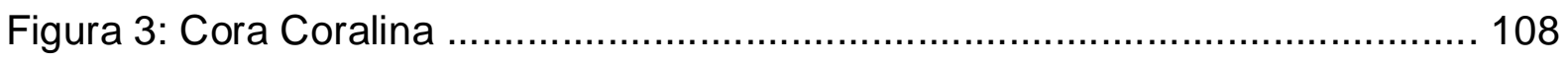

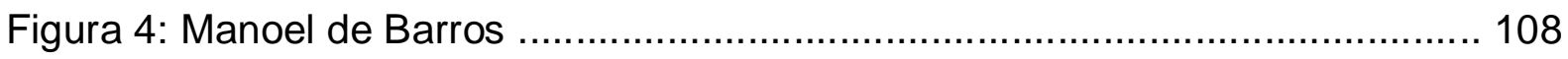




\section{SUMÁRIO}

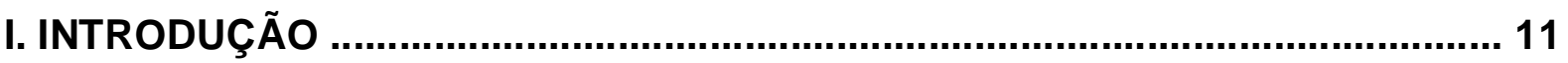

CAPÍTULO I: CORA CORALINA: ENTRE O FOGÃO E A ESCRIVANINHA ........ 21

1.1 - Poesia, ancestralidade e infância no prato azul-pombinho .......................... 26

1.2 - O Poema do milho: retrato poético-identitário de um Brasil profundo ............ 37

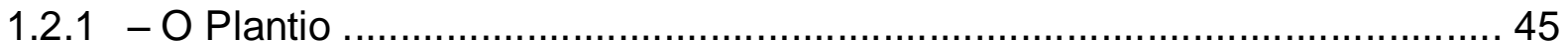

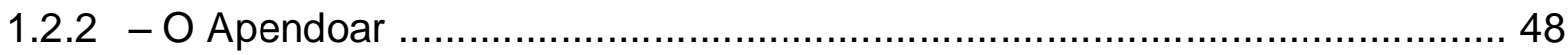

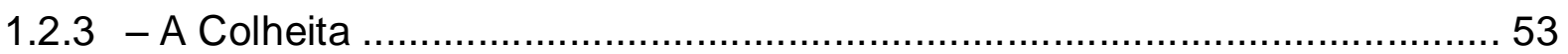

1.3 - Um "acontecido" sobre natureza e acolhimento: Os meninos verdes ........... 55

CAPÍTULO II: MANOEL DE BARROS: ENTRE O QUINTAL E OS POEMAS ...... 65

2.1 - O quintal-mundo do Menino do mato .................................................... 69

2.2 - Fantasia em Prosa e Poesia nas Memórias Inventadas: As Infâncias de Manoel

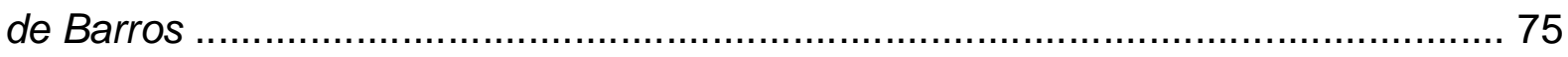

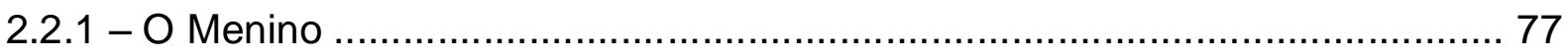

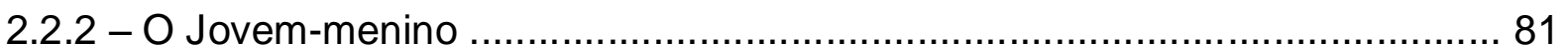

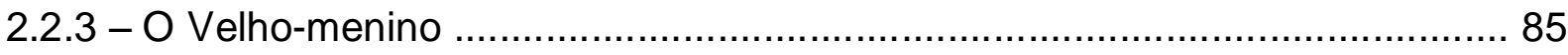

2.3 - Palavra-brinquedo: infância poética entre as Ignorãças e o Nada .................. 90

2.3.1 - Poesia do (des)aprender ......................................................... 93

2.3.2 - O nada e suas transbordâncias .......................................................... 99

CAPÍTULO III: COZINHA E QUINTAL: LETRAS DA ESCRIVANINHA .............. 109

3.1 - (Des)limites da palavra em Cora Coralina e Manoel de Barros ................... 114

3.2 - Por uma infância poética: entre doces na cozinha e brincadeiras no quintal 125

3.3 - Essência identitária brasileira: para além da periferia e do centro ................ 129

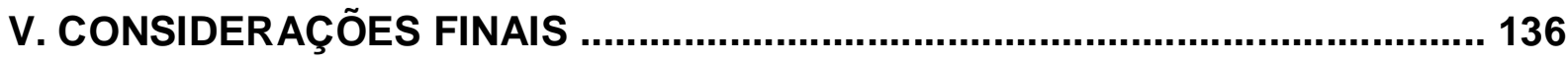

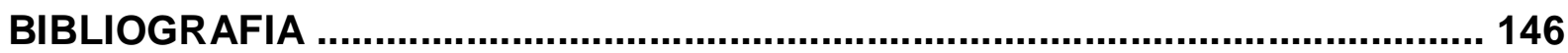

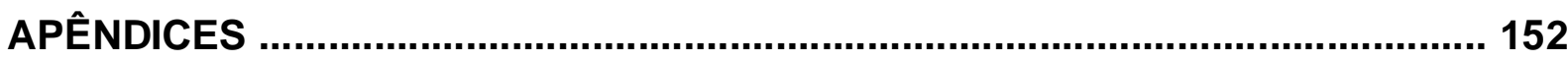

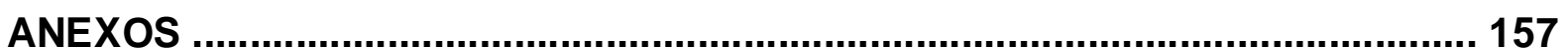




\section{INTRODUÇÃO}

A poesia é conhecimento, salvação, poder, abandono. (...) A poesia revela este mundo; cria outro. (...) regresso à terra natal. (...) Expressão histórica de raças, nações, classes. (...) em seu seio resolvem-se todos os conflitos objetivos e o homem adquire, afinal, a consciência de ser algo mais que passagem. (...) Regresso à infância (...)

Octavio Paz, in O Arco e a Lira. São Paulo: Cosac Naify, página 13, 2012

Há muita poesia nos interiores do Brasil. Neles, há uma misteriosa e serena morosidade no tempo. Quintais, com suas hortas, jardins, pomares, tornam-se terrenos férteis para um sem fim de brincadeiras; mangueiras, jabuticabeiras e goiabeiras tornam-se facilmente castelos; jardins são ingenuamente mutilados em nome do sorriso nos lábios de princesas, espantalhos tornam-se inimigos a serem vencidos, mas é preciso ter cuidado, afinal estão protegidos por canteiros de onde brota o alimento sagrado e que, portanto, não podem ser profanados.

Nas casas dos interiores, as cozinhas são templos mágicos, lugares de onde fadas-mães-avós preparam toda sorte de compotas, doces de leite e bolos. A cozinha exala aromas que se tornam a memória afetiva da infância. Nelas, famílias se reúnem no período da colheita do milho, num ritual de recriação que ocorre desde tempos imemoriais, e que faz brotar, em meio a um trabalho coletivo e fraternal, pamonhas, curaus, bolos de todos os tamanhos.

As ruas nos interiores são largas, ideais para todo tipo de brincadeiras, de bolinhas de gude a queimadas, passando pelo pião e pelas pipas, que irremediavelmente invadem as casas dos vizinhos, o que não é necessariamente um problema. Afinal, nos interiores, todos se conhecem, crianças tratam adultos de "tio" e "tia", no caso dos mais velhos, "vô" e "vó", sem necessariamente possuírem quaisquer graus de parentesco; a proximidade entre as pessoas torna-as membros de uma única família.

A natureza nos interiores é de recôndita exuberância: cachoeiras, nascentes, riachos, se revelam apenas aos que ousam se aventurar nas matas, atravessando milharais, canaviais, resquícios de mata virgem. Nos interiores a relação com a natureza é visceral, harmônica, dotada de tamanha pureza, garantida pelos pés, sempre descalços, das crianças. 
É de alguém que viveu nesse contexto que nasce esta tese, um menino que se aproximou da poesia e desde cedo colhera o fruir da linguagem poética na companhia de Drummond, Bandeira, Quintana, Thiago de Melo. A prosa passou a ser quase uma obrigação, um pretexto para procurar a poesia. Na adolescência, apaixonou-se perdidamente pela poesia de Cecília Meireles, deixou-se inebriar, e pelas mãos dela viajou, primeiro para Minas do século XVIII através do Romanceiro da Inconfidência na graduação, de lá para Holanda dos Doze Noturnos na especialização e então para o Oriente. A Índia fora o último destino dos amantes que, sob as bênçãos do Ganges, se separaram carinhosamente após o Mestrado.

Todavia, era preciso regressar ao Brasil, e assim o agora homem das letras é novamente arrebatado pela poesia. Contudo não se tratava de uma poesia estranha a ele, ao contrário, remete-o às suas mais profundas raízes, leituras adormecidas na memória pela paixão anterior, mas que retornaram com mais desejos de descobertas, com mais perguntas.

Por meio deste estudo, as obras de Cora Coralina e Manoel de Barros se fizeram presentes, proporcionando-Ihe reviver poeticamente a sensação de brincar no quintal, de sentir o aroma da cozinha, de tocar a terra de pés descalços, permitindo-lhe (re)encontrar-se com o menino de outrora. Não havia dúvidas: estavam escolhidos os autores cujas obras compõem os corpora desta tese. Era apenas o primeiro passo de uma longa jornada, repleta de desafios e questões.

Afinal, como propor uma análise comparativa inédita entre duas obras cuja construção poética - aparentemente díspar -, ao apresentar reminiscências de infâncias ocorridas em diferentes regiões do Brasil - uma no interior do Mato Grosso, outra no de Goiás - valem-se de elementos, contextos e temas que, por meio da linguagem poética, parecem transcender fatores regionais, dialogando significativamente com experiências infantis que, do ponto de vista cultural e identitário, podem permear todo país, não deixando também de abarcar, do ponto de vista temático, questões universais?

De um lado, o renomado poeta mato-grossense, estabelecido popular e academicamente, de outro a escritora goiana, que se autonomeava rapsoda ${ }^{1}$, e cujo

\footnotetext{
${ }^{1}$ Modo como a própria autora costumava referir-se a ela mesma em seus poemas, como pode ser verificado no poema "Sou Raiz" (Anexo XIII). O termo se refere a um tipo de poeta popular, ou cantor, que ia de cidade em cidade recitando poemas épicos.
} 
tardio reconhecimento pendeu, em muitos momentos, mais para o folclórico do que para o literário, ficando muito aquém de sua real contribuição artística e cultural.

Com motivação em tais pensamentos, foram traçados para a pesquisa os seguintes objetivos:

a) averiguar como tanto textos poéticos de Cora Coralina - editados como obras de literatura infantil - quanto de Manoel de Barros desenham uma infância cujas experiências retratadas, embora figurem em ambientes bucólicos dos interiores de Goiás e do Mato Grosso, podem dialogar, ainda na contemporaneidade, com vivências infantis ao redor do país;

b) estabelecer um diálogo entre as obras de Cora Coralina e Manoel de Barros, a fim de demonstrar 0 quanto as especificidades das literaturas de ambos se complementam esteticamente no que concerne à representação poética, cultural e identitária das experiências infantis do interior do Brasil;

c) verificar em que medida as literaturas de Cora Coralina e Manoel de Barros, uma vez levadas às salas de aula, especialmente aos alunos do Ensino Fundamental I e II, podem proporcionar possibilidades de contato com representações poéticas capazes de tocá-los, auxiliando-os tanto no processo de formação leitora, cultural e identitária, quanto no de sensibilização acerca da compreensão da pluralidade artístico-literária do país, independentemente do espaço histórico-geográfico a que pertençam.

Para tanto, a metodologia baseou-se nos estudos comparatistas, sendo que se buscam na literatura as representações para os diálogos entre as obras, bem como se compararam representações contidas nos textos literários com o universo cultural dos quais esses textos surgiram e com os quais procuram dialogar.

Além disso, era preciso escolher as obras que comporiam os corpora da pesquisa propriamente ditos. Eis outro desafio, pois, ao contrário de Manoel de Barros, originalmente Cora Coralina não produzira livros especificamente voltados para o público infantil; os livros lançados pela escritora em vida são apenas quatro, a saber: Poemas dos Becos de Goiás e estórias mais (1965); Meu Livro de Cordel (1976); Vintém de Cobre - Meias confissões de Aninha (1983); Estórias da Casa Velha da Ponte (1985).

Tal fato não quer dizer que a autora não escrevera para crianças, haja vista que muitos de seus poemas e alguns contos tornaram-se, ainda que adaptadas, obras infantis de grande sucesso popular. Ademais, longe de querer minimizar a 
importância das ilustrações no contexto editorial da produção de obras para crianças e jovens, esta pesquisa objetiva abordar o texto poético em sua essência.

Já o poeta mato-grossense construiu sua obra tendo a infância como cenário principal, o que também, de certa forma, tornava complexa a escolha. Daí a necessidade de se estabelecerem critérios que norteiem um recorte capaz de possibilitar um diálogo profícuo entre os autores, uma vez que seria impossível abarcar em uma única tese toda a obra literária de Cora Coralina e Manoel de Barros.

Assim, o que garantiu produzir esta tese a partir de uma metodologia comparativista fora a profunda relação temática dos poetas com as questões ligadas a elementos familiares a regiões pertencentes aos interiores do Brasil, como a vida rural e o apego à natureza. Privilegiou-se a temática, sem evidentemente se desconsiderarem as especificidades entre a construção estética do texto poético na literatura de ambos, cujas diferenças poderiam até tornar, num primeiro momento, desaconselhável essa aproximação.

Observou-se ainda que, além de uma temática que realça a vivência em comunhão com a natureza, a necessidade de harmonia e empatia na relação entre adultos e crianças e a beleza e a simplicidade do olhar da criança diante das circunstâncias da vida, ainda os autores manifestam também grande preocupação com a formação da criança e do jovem, o que é um assunto muito caro à pesquisa de literatura infantil e juvenil no país.

Selecionaram-se dois exemplos dessa postura artística dos autores. Cora Coralina, por exemplo, no início do livro Poemas dos becos de Goiás e estórias mais - primeira obra publicada pela poeta - explicita no breve texto "Ao leitor" o propósito mencionado acima e que permeará toda a sua obra:

\footnotetext{
Alguém deve rever, escrever e assinar os autos do Passado antes que o Tempo passe tudo a raso.

É o que procuro fazer para a geração nova, sempre atenta e enlevada nas estórias, lendas, tradições, sociologia e folclore de nossa terra.

Para a gente moça, pois, escrevi este livro de estórias. Sei que serei lida e entendida. (CORALINA, 2014, p. 25)
}

Por sua vez, Manoel de Barros, no texto "Manoel por Manoel", publicado no início do livro Memórias Inventadas - As Infâncias de Manoel de Barros, ao escrever 
sobre si mesmo, também acaba por apontar traços que perpassam toda a sua literatura:

\begin{abstract}
(...)
Porque se a gente fala a partir de ser criança, a gente faz comunhão: de um orvalho e sua aranha, de uma tarde e suas garças, de um pássaro e sua árvore. Então eu trago das minhas raízes crianceiras a visão comungante e oblíqua das coisas. Eu sei dizer sem pudor que o escuro me ilumina. É um paradoxo que ajuda a poesia e que eu falo sem pudor. Eu tenho que essa visão oblíqua vem de eu ter sido criança em algum lugar perdido onde havia transfusão da natureza e comunhão com ela. Era o menino e os bichinhos. Era o menino e o sol. O menino e o rio. Era o menino e as árvores. (BARROS, 2008, p. 11)
\end{abstract}

Observada tal questão, o passo seguinte foi fazer um recorte nas obras que permitisse o desenvolvimento da tese de modo coerente e honesto, que pudesse atender às demandas da contemporaneidade. Nesse sentido, a ideia era selecionar obras capazes de representar, ao mesmo tempo, além da já mencionada preocupação dos poetas para com a formação do leitor, o modo como desenham poética e culturalmente a infância nos interiores do país, considerando o trabalho estético de ambos.

Aqui vale um adendo: no caso das obras de Cora Coralina, escolheram-se livros que não foram concebidos originalmente como infantis. $\mathrm{Na}$ verdade, trata-se de poemas que, embora abordem intimamente a infância, receberam uma "roupagem", do ponto de vista da forma, que os travestiu de livros infantis. Todos os textos foram primeiramente publicados nas quatro obras mencionadas no início desta Introdução, fato que constitui a principal razão pela qual será privilegiada, sem querer desmerecer e ou minimizar a importância da ilustração, a palavra poética.

Assim, pode-se dizer que, no caso de Cora Coralina, selecionaram-se textos que procuravam atender, do ponto de vista editorial e mercadológico, às demandas da contemporaneidade, sendo concebidos como livros para crianças num segundo momento. Entretanto não se pode deixar de mencionar que tal concepção só foi possível porque a construção original dos poemas permitiu o que é, evidentemente, mérito do talento da escritora.

Não é o caso das obras de Manoel de Barros, que, embora voltadas para todos os públicos, mantiveram sua forma editorial original, ou seja, sem serem submetidas a quaisquer adequações e ou "roupagens". Possuem, do ponto de vista da ilustração, ora alguns traços do próprio poeta - como, por exemplo, o 
emblemático desenho de "Felismundo" -, ora algumas "iluminuras" produzidas pela filha do poeta, Martha Barros, que acompanham os poemas nas obras, sem necessariamente estabelecerem uma relação dialógica com elas.

Dessa forma, procurou-se fazer um recorte, envolvendo livros cujas edições e reedições avançaram o século XXI, consubstanciando-se como títulos emblemáticos da bibliografia voltada para o público infantil e juvenil de ambos os autores, o que inseriu tanto Cora Coralina quanto Manoel de Barros no cenário contemporâneo da literatura infantil e juvenil.

Considera-se relevante mencionar a questão da importância da presença dos autores no cenário não só da literatura infantil e juvenil, mas, sobretudo, da literatura brasileira, porque, apesar de terem passado quase despercebidamente pelos seus pares e pela crítica literária de um modo geral, Cora Coralina e Manoel de Barros gozam de considerável aceitação popular em pleno início de século XXI.

Embora produzam uma poesia que contemple elementos notadamente distantes das tendências digitais, ambos resgatam situações e elementos subjacentes aos interiores do país, capazes de estabelecer diálogo com uma gama de infâncias que parecem residir no cerne da constituição do imaginário infantil cultural brasileiro, a despeito de todas as questões que envolvem as mídias digitais.

Organizou-se esta tese em três capítulos, a saber: o primeiro dedicado a Cora Coralina, o segundo a Manoel de Barros e o terceiro ao estabelecimento do diálogo entre ambos no cenário brasileiro da literatura infantil e juvenil e às questões que envolvem a relevância do texto poético no processo de formação identitária e cultural do leitor, chegando então às considerações finais.

O primeiro capítulo é composto pelas obras O prato azul-pombinho, Poema do milho e Os meninos verdes. Lembrando que, exceto a última obra, os poemas que figuram nas duas primeiras pertencem, originalmente, ao primeiro livro da autora - Poemas dos becos de Goiás e estórias mais.

Além disso, no caso do poema "O prato azul-pombinho", trata-se de um desdobramento do poema "Estória do Aparelho azul-pombinho" (Anexo I). Ele foi concebido como obra para crianças em 2002. Sua nova "roupagem" contou com a ilustração de Lúcia Hiratsuka e já conta com quatro edições sendo a última em 2011, com a 3를 reimpressão em 2015.

Em relação ao "Poema do milho", embora não seja um desdobramento, dialoga profundamente com o poema "Oração do milho". Talvez por tal 
profundidade, ambos compuseram a obra Poema do milho, cuja primeira edição, ilustrada por Marcelo Eduardo Lélis de Oliveira, fora lançada em 2006, tendo a terceira edição lançada em 2011, com a 2ª reimpressão em 2015.

Já o livro Os meninos verdes se destaca em nossa pesquisa, em primeiro lugar, pelo sucesso editorial do conto que, publicado originalmente em $1968^{2}$, se tornou livro em 1980 e, desde então conta doze edições, a última em 2007, ilustrada por Cláudia Scatamacchia, cuja 7ª reimpressão ocorrera em 2017; em segundo lugar, porque privilegiou, no tocante à estética coralineana, a prosa ao invés da poesia; e por último, por conta da contemporaneidade da temática, voltada para questões que envolvem visceralmente a relação entre o homem e a natureza.

O segundo capítulo reúne as obras Menino do mato, Memórias inventadas: as infâncias de Manoel de Barros, Livro sobre nada, O livro das ignorãças. Houve considerável complexidade em tal recorte, primeiro pela quantidade considerável de obras do autor, desde seu primeiro livro - Face imóvel - publicado em 1942 até o último - Portas de Pedro Vieira - em 2013, foram mais de vinte títulos.

Segundo porque embora quase todas as obras de Manoel de Barros tragam em sua construção questões intimamente relacionadas ao universo infantil e juvenil, seus livros são catalogados simplesmente como "Poesia brasileira" e não como "Poesia infantil" e ou "Poesia juvenil", o que potencializa o grau de complexidade para o estabelecimento de critérios de escolha das obras abordadas.

Optamos então pelas obras que marcam, cronologicamente, a transição do século XX para o século XXI, selecionando os dois últimos livros lançados naquele e dois dos primeiros livros publicados na primeira década deste, sendo os representantes do final do século XX: O livro das ignorãças e o Livro sobre nada, publicados respectivamente em 1993 e 1996, ambos tiveram suas terceiras edições em 2016. E Memórias inventadas: as infâncias de Manoel de Barros e Menino do Mato, ambos publicados na primeira década do século XXI - 2008 e 2010 respectivamente - cujas segundas edições também foram produzidas em 2016.

Ressalta-se que todas as obras de Manoel de Barros foram reeditadas em 2016 por questões comerciais, ou seja, os direitos autorais de sua obra deixaram de

\footnotetext{
${ }^{2}$ A referência de 1968, observada no acervo do Museu Cora Coralina, sugere considerá-lo como período de sua produção. Os manuscritos indicam que a poeta se encontrava na cidade de Aruanã quando o escreveu e que o Presidente da República citado no conto seria o militar Arthur da Costa e Silva cuja esposa Yolanda B. da Costa e Silva possuía familiares em Goiás e mantinha amizade com a escritora através de cartas e visitas. (BRITTO, 2006, p. 86)
} 
pertencer ao grupo lusitano LeYa Brasil e passaram a pertencer à editora carioca Alfaguara. Todavia, o que interessa a nós nesta tese é a notória pujança com que a literatura de Manoel de Barros é recebida na contemporaneidade.

No terceiro capítulo são tecidas reflexões acerca das obras dos autores em relação à dinâmica artística, cultural e histórica da literatura infantil e juvenil brasileira, bem como a relevância do diálogo entre poesia, imaginário, cultura, identidade no processo de formação humana da criança e do jovem. Para tecer tais reflexões, evidenciaram-se três aspectos considerados fundamentais no processo dialógico proposto entre a poesia de Cora Coralina e Manoel de Barros.

Primeiro, a presença do elemento "simplicidade" na concepção da linguagem poética de ambos os autores. Segundo, o modo como ambos constroem poeticamente os espaços da "cozinha" e do "quintal" na dinâmica cultural brasileira e sua relevância no universo infantil dos interiores; a linguagem poética em ambos trata a relação entre o adulto e a criança. E por último, mas não menos importante, o modo como a obra de Cora Coralina e Manoel de Barros representa a essência identitária brasileira, constituindo-se imprescindível no processo de formação de leitores, dada a sua concepção de infância.

Ao final da tese espera-se:

a) sinalizar no texto poético a capacidade de construir, fortalecer e ou solidificar no imaginário infantil e juvenil aspectos ligados ao aguçamento da sensibilidade e consequente percepção estética e às dimensões culturais e identitárias que os acompanharão ao longo de sua existência;

b) ampliar a pesquisa acadêmica acerca da literatura de Cora Coralina, não apenas por se entender que ela está aquém da contribuição dessa autora para a literatura brasileira, mas, sobretudo, por se reconhecerem em sua poesia elementos culturais brasileiros que remetem a um Brasil ancestral e que podem contribuir profundamente para o fortalecimento da compreensão identitária e artística. $\mathrm{Na}$ Universidade de São Paulo, por exemplo, após pesquisa no banco digital de dados, foi encontrada apenas uma tese sobre a autora, e não pertence à área de Letras (Apêndice A);

c) enriquecer ainda mais a seara da pesquisa acadêmica no tocante à obra de Manoel de Barros, um poeta estabelecido tanto para o grande público quanto para a academia de um modo geral, sendo objeto de muitos artigos, dissertações e teses (alguns exemplos constam no Apêndice B), entretanto não se pode deixar de notar 
que, quando se trata de trabalhos voltados para questões envolvendo literatura infantil e juvenil, a pesquisa envolvendo o poeta também fica aquém da grandeza de sua obra.

d) colaborar minimamente para com a pesquisa científico-acadêmica voltada para a importância do texto poético na literatura infantil e juvenil, por se acreditar que a quantidade de trabalhos que contemplam poesia, particularmente aquela destinada e ou associada à criança e ao jovem, está ainda muito aquém do necessário, visto que, num sentido amplo, "a poesia é a mal-amada dos leitores em geral" (Coelho, 1982, p. 148).

Apresentadas as veredas desta tese, deseja-se que o leitor tenha adiante, seja pelo retrato da infância recheada de compotas, tradições familiares ancestrais e histórias da bisavó da obra de Cora Coralina, seja pelo desenho de uma infância de pés descalços, em comunhão com a natureza, que extrai da observação das miudezas o sentido da vida, da obra de Manoel de Barros, um caminho mais terno, sublime, poético, como toda infância deveria ser: cheia de sonhos. 
Figura 1: A escrivaninha de Cora Coralina

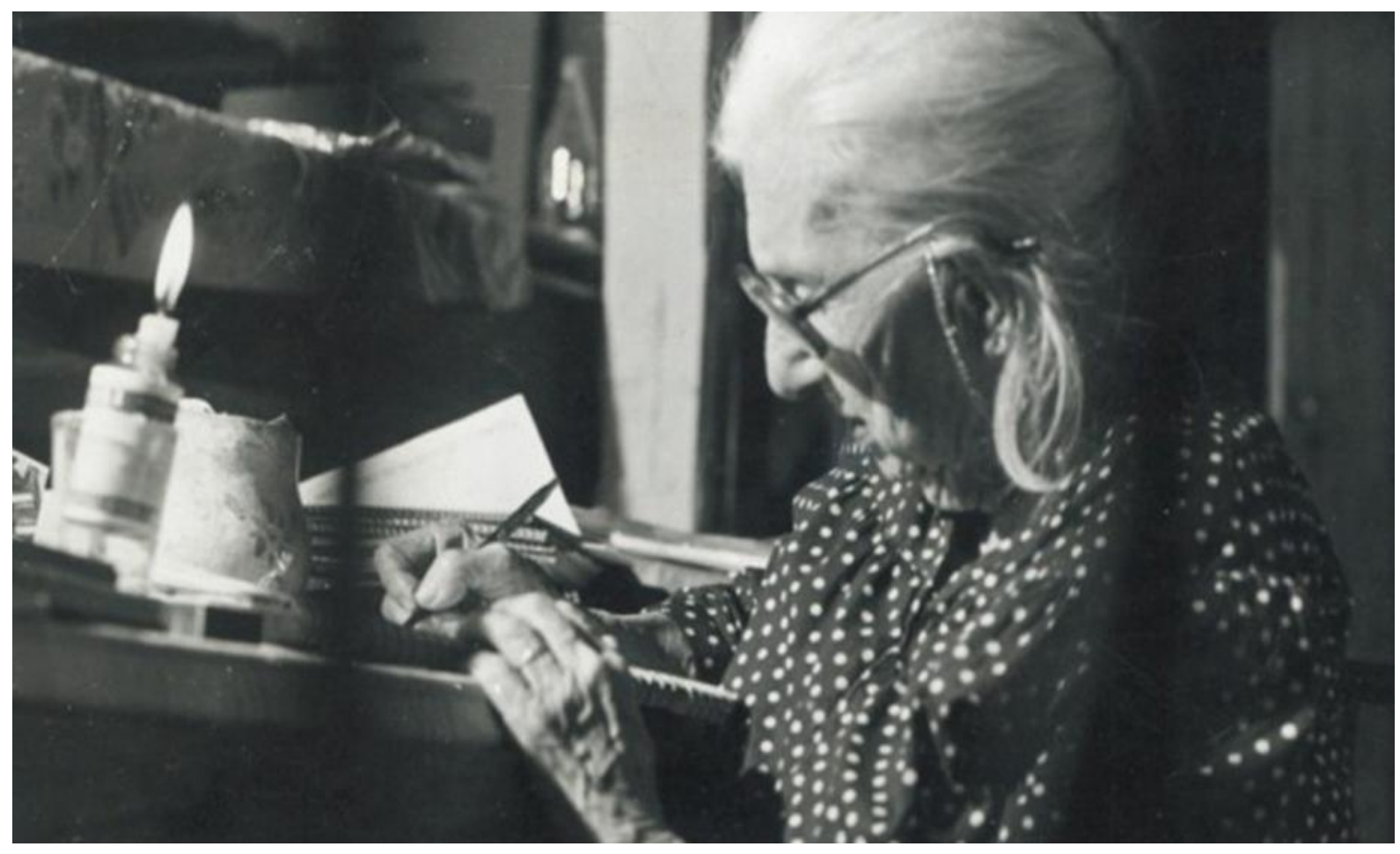

Fonte: https://www.recantodasletras.com.br/poesias/5366680, acesso em: 18/11/2019. 


\section{CAPÍTULO I: CORA CORALINA: ENTRE O FOGÃO E A ESCRIVANINHA}

Já não faz mais doces e segredava: sou doceira, a poesia é só o acaso. Tinham pouco açúcar e eram doces e esse, dizia, é o meu segredo.

Carlos Rodrigues Brandão, in Cora Coralina: raízes de Aninha, 2009, p.10.

Anna Lins dos Guimarães Peixoto Brêtas, nascida no final do século XIX (20/08/1889), falecida quase no final do século XX (10/04/1985) em Goiás, filha de pai nordestino - Francisco Lins dos Guimarães Peixoto - e de mãe goiana Jacyntha Luiza do Couto Brandão -, foi terceira filha de quatro irmãos. Viveu sua infância entre a Casa Velha da Ponte, às margens do rio Vermelho - centro de Goiás, então capital do estado -, passeando entre becos da cidade e a propriedade rural da família - Fazenda Paraíso -, lugares que mais tarde compuseram cenários poéticos fulcrais em sua obra.

Quanto ao nome Cora Coralina, segundo ela própria anos mais tarde, em entrevista ${ }^{3}$ à TVE, fora inventado e adotado para diferenciar-se de outras "Annas" nome muito comum na região naquela época, que tinha por padroeira Sant'Anna além disso, vale ressaltar que era prática corriqueira a adoção de pseudônimos no início do século XX, principalmente por mulheres que se aventuravam a escrever.

Ocorre que, nesse caso, o codinome sobrepujou o nome, de modo que Anna Lins dos Guimarães Peixoto Brêtas acabou, intencionalmente ou não, sendo obliterada por Cora Coralina tanto na vida quanto na arte, e esta, por sua vez, numa profunda relação de alteridade, devolveria a gentileza, dando vida e voz ao "eu" poético "Aninha", aquela menina cujas aventuras, sufocadas até então, desabrocharam.

Pois é assim, na última estrofe de um dos primeiros poemas - "Minha cidade" -, do primeiro livro publicado pela poeta, Poemas dos becos de Goiás e estórias mais; aos seus 76 anos, que ela se apresenta aos leitores: “(..) Eu sou a menina feia / da ponte da Lapa. / Eu sou Aninha.” (CORALINA, 2014, p. 36).

Entretanto, antes de mergulhar mais profundamente no universo coralineano, entre o fogão e a escrivaninha, é preciso entender, ainda que panoramicamente,

\footnotetext{
${ }^{3}$ Entrevista para o "Especial Literatura” - TVE, n.14, 29 de janeiro de 1985.
} 
quem foi essa mulher que ao, peregrinar pela vida, acabou regressando para o lugar onde residiam suas raízes, (re)encontrando na sua velhice aquelas que the devolveriam as suas asas, as memórias adormecidas de sua meninice.

Mesmo dedicando-se à maternidade, às questões do lar e ao marido - que não necessariamente incentivava sua atividade literária -, Cora Coralina não deixou de produzir seus textos e enviar para os jornais ${ }^{4}$. Tal postura ajuda-nos a desconstruir a imagem puramente mercadológica da mulher que se tornara escritora apenas na velhice, apesar de a autora já figurar com seus escritos nos jornais, desde os 16 anos, tanto em Goiás ${ }^{5}$ quanto no estado de São Paulo.

Dessa forma, cabe evidenciar que, apesar de não ser considerada pertencente a nenhum movimento literário e tampouco tenha seu nome reconhecido pela crítica especializada na primeira metade do século $X X$ - e por que não dizer também pela contemporânea -, é possível enxergar na estética da poesia de Cora Coralina traços das principais reivindicações das três gerações modernistas, tais como: o verso livre, a utilização de recursos da oralidade ou a temática cotidiana, próprios da primeira geração; o regionalismo da segunda e o universalismo da terceira.

Ela mesma chegou a declarar no artigo "A vitória de Cora", publicado na Revista Análise de Goiânia, em 1984, o modo como pensava poesia:

Eu só me libertei da dificuldade poética depois do modernismo de 22, mas não acompanhei o movimento. Não sei como - não posso explicar como me achei dentro daquela mudança. Em primeiro lugar, poesia para mim é comunicação; em segundo lugar é invenção, porque só o gênio cria. Hoje nós temos que achar a poesia na realidade da vida e a vida toda é poesia. Porque onde há vida, há poesia. Poesia para mim é um ato visceral. É um impulso que vem de dentro e, se eu não obedecê-lo, me sinto angustiada. (p. 10-12)

Voltando à peregrinação da escritora pelo estado de São Paulo, em 1929 a autora, a fim de proporcionar melhor educação para os filhos, mudou-se para a

\footnotetext{
${ }^{4}$ Mais uma vez destaca-se a postura autônoma da escritora. Na biografia Cora Coralina: Raízes de Aninha consta que em Jaboticabal "foi limitada em seus escritos por falta de tempo." Entretanto, "Ela conseguia driblar os afazeres e, nas dobras do tempo, escrevia. (...) Para A Informação Goyana, enviava suas reminiscências sobre Goiás. Para o jornal $O$ Democrata, coisas sobre Jaboticabal. No Estado de São Paulo, crônicas pertinentes a um jornal com ampla área de leitores. (...) Mesmo sem incentivo de Cantídio, (...) Cora Coralina nunca deixou a escritora adormecer (...)" (p. 127)

${ }^{5}$ Jornal literário $A$ Rosa que, segundo consta na biografia Cora Coralina: Raízes de Aninha, era "(...) considerado pela crítica como veículo das ideias da intelectualidade goiana da época." (p. 71).
} 
capital paulista, afastando-se um pouco de seu marido - que fora transferido para Salto Grande. Lá trabalhou como vendedora de livros para a Editora José Olympio de 1931 a 1936 - o marido veio a falecer em abril de 1934 - e Cora Coralina, para acompanhar a filha Jacyntha, nomeada professora no então Ginásio Estadual de Penápolis, hoje Escola Estadual Dr. Carlos Sampaio Filho, voltou para o interior do estado.

Permaneceu por aproximadamente cinco anos em Penápolis, onde, como em Jaboticabal, participou ativamente da vida social da cidade, escreveu no jornal local, abriu uma casa comercial de tecidos, ingressou na Venerável Ordem Terceira Franciscana, designada atualmente Ordem Franciscana Secular e, sempre engajada, ajudou a fundar a Associação Comercial de Penápolis ${ }^{6}$, sendo a única mulher a integrá-la naquela ocasião.

Em 1941, com 52 anos de idade, aproveitando-se do processo de desbravamento do Oeste Paulista, migrou para a então recém inaugurada cidade de Andradina, levando consigo seu comércio de tecidos e sua capacidade de se reinventar. Nessa época seus filhos já estavam estabelecidos: "Vicência estudando em Penápolis, morando na casa da irmã Jacyntha, Cantídio Brêtas Filho residente em Campo Grande, Paraguassu e Guajajarina casadas e com filhos." (BRITTO; SEDA, 2009, p. 205)

Além da casa comercial, Cora Coralina adquiriu um sítio em Andradina - Sítio "Casinha Branca" - de 25 alqueires, por sete contos de réis. Surgia então a Cora sitiante, ou, como se tornara conhecida em Andradina, Cora Brêtas, ou ainda simplesmente dona Cora. Estabeleceu-se como comerciante e agricultora, cultivando, sobretudo, milho.

Nessa época escreveu dois de seus textos mais emblemáticos ${ }^{7}$ : "Oração do Milho" e "Poema do Milho", ambos figuraram no primeiro livro da poeta - Poemas dos Becos de Goiás e estórias mais. Depois, já no século XXI, mais precisamente no ano de 2006, foram republicados como obra de literatura infantil - que será contemplada de modo mais detalhado ainda neste capítulo -, ganhando forma e ilustrações próprias.

\footnotetext{
${ }^{6}$ Ata da reunião da Associação Comercial de Penápolis. Acervo do Museu Histórico e Pedagógico Glaucia Maria de Castilho Muçouçah Brandão.

${ }^{7}$ Informação extraída da obra biográfica: Cora Coralina: Raízes de Aninha, 2009, página 208.
} 
No final das contas, Cora Coralina tornou-se uma personalidade em Andradina, ganhando notoriedade cultural, social e política. Em 12 de abril de 1985, o principal jornal da cidade - O Jornal da Região - publicou o artigo "Cântico de Andradina: imortal herança de Cora Coralina", afirmando que ela:

Com essa intimidade nos meios sociais, cívicos e culturais, na gleba como na cidade, (...) viveu 15 anos em Andradina, onde escreveu e publicou na imprensa local grande parte da sua produção literária, que reuniu mais tarde em livros e publicou em Goiás. Aqui ela se fez ídolo antes que em sua própria terra.

A volta à sua terra natal se deu em 1956, 45 anos depois de sua partida. Retornou sozinha para tratar de demandas jurídicas que envolviam o inventário e, consequentemente, a posse da Casa Velha da Ponte, entretanto não se desfez, num primeiro momento, de suas conquistas no estado de São Paulo: a casa comercial e o sítio em Andradina. Voltou algumas vezes à cidade, ora para receber homenagens, ora para cuidar de assuntos particulares ${ }^{8}$.

Entretanto sua permanência em Goiás fora inevitável, não apenas porque as questões judiciais envolvendo a Casa Velha da Ponte se estenderam além do previsto, mas, sobretudo, porque, mesmo com todos os seus permanecendo no estado de São Paulo, decidira ficar.

Em entrevista a Vicente Fonseca e Armando Lacerda, durante a fase de prospecção do documentário "Cora Doce Coralina”, em 1982, declarou:

\begin{abstract}
O meu local é aqui. O meu estado é aqui. A minha vida é aqui, porque aqui eu tenho as minhas raízes. (...) Eu vivi em cidades ótimas no estado de São Paulo e deixei mais do que cidades, deixei filhos, netos, bisnetos, nora e genros, gente que me queria bem e me quer bem e me respeita e voltei para minha terra chamada pelas raízes, as minhas raízes ancestrais. Eu ouvi um chamado das pedras da minha cidade. E eu acabei voltando. E aqui estou integrada. Não quero nada mais do que esta casa velha, estas pobrezas que me cercam e que eu me liguei de novo. (...) Quando eu me afastei da família eu tinha dado a essa família 45 anos de minha vida, portanto nenhum sentimento de culpa, apenas um sentimento de quem cumpriu um dever. Eu tinha me dado aos meus filhos durante 45 anos. Chega. Tinha também o direito de viver a minha vida. (BRITTO; SEDA, 2009, p. 251)
\end{abstract}

Embora tenha voltado, segundo ela mesma, "chamada pelas raízes", tal ato representava para Cora Coralina o ápice de sua libertação, como reforçara,

\footnotetext{
${ }^{8}$ Informação extraída da obra biográfica: Cora Coralina: Raízes de Aninha, 2009, página 238.
} 
afirmando: "(...) Fui limitada na primeira infância, fui limitada de menina, fui limitada de adolescente, fui limitada de casada e não quero ser limitada depois de velha. (...) Não há nada que valha para mim a minha libertação" 9 .

A breve abordagem biográfica inicial deste capítulo deseja ilustrar o quão não seria incorreto dizer que em Goiás as raízes e as asas de Cora Coralina, ainda que aparentemente de modo paradoxal, confluíram, como uma grande árvore de raízes profundas, fincadas nas pedras da Casa Velha da Ponte, às margens do Rio Vermelho, mas de copa frondosa.

Tal metáfora possibilita entender que, embora seja comum associar a obra da autora às suas raízes, esta tese pretende abordar as asas da literatura de Cora Coralina, especialmente em sua obra infantil. Da mulher que, regressando para o lugar mais ancestral do imaginário de sua infância, fez ecoar a plenitude de sua liberdade, dando voz àquelas memórias até então recônditas pelas várias circunstâncias da vida.

Nesse cenário, como citado anteriormente, Cora Coralina faz desabrochar o "eu" poético "Aninha" que, por meio de poemas-narrativos e ou narrativas-poéticas, carregam em si toda a vivacidade de outrora, uma vez que permitem ao leitor passear, de mãos dadas com a criança Aninha, ora pelos becos da velha Goiás, ora pela Fazenda Paraíso.

Todavia, dialogando com o título deste capítulo, não se pode deixar de mencionar que, antes da poeta, fez-se a doceira. A menina que muito cedo auxiliava as mulheres da família nos afazeres culinários, desde a cuidadosa colheita e seleção de frutas no quintal-pomar, até a preparação de ingredientes e utensílios da cozinha.

Nesse contexto, é preciso ressaltar que a autora viveu sua infância numa atmosfera em que trabalho, brincadeira, estudos (quando possível), duros castigos e rodas de histórias se entrelaçavam, pois não se pode desconsiderar que estamos nos referindo a Goiás no final do século $\mathrm{XIX}$ e início do $\mathrm{XX}$, tempo em que as crianças ainda eram enxergadas como adultos em miniatura.

Talvez por isso seja difícil enxergar na literatura de Cora Coralina algum estranhamento no tratamento que lhe era dispensado quando menina. Ao contrário, todas as circunstâncias retratadas por ela, referentes ao seu tempo de menina,

\footnotetext{
${ }^{9}$ In: BOTASSI, M. Cora Coralina conta um pouco de sua história, p. 9.
} 
desde o trabalho na cozinha e os severos castigos e reprimendas, até as lições transmitidas rispidamente na escola, foram feitas de forma saudosista e por que não dizer romântica.

Em se tratando do trabalho na cozinha, por exemplo, uma das possíveis explicações capazes de justificá-lo, talvez resida no fato de que o ofício de doceira, além de ser o maior motivo de orgulho para Cora Coralina, foi o que garantiu sua sobrevivência no processo de retorno a Goiás, fazendo-a olhar com gratidão a tudo que Ihe fora transmitido, desde a infância, pelas mulheres de sua família, doces cuja fama, assim como os poemas, transcendeu as fronteiras de Goiás ${ }^{10}$.

Assim, é possível dizer seguramente que o legado da artista Cora Coralina permeia a culinária e a literatura, ambas produzidas sob a perspectiva de uma relação simbiótica: na obra coralineana, a poesia é doce e o doce é poesia.

\section{1 - Poesia, ancestralidade e infância n'O Prato Azul-Pombinho}

O Prato Azul-Pombinho é uma das obras mais emblemáticas de Cora Coralina destinada ao público infantil, composta por um poema de mesmo nome, fruto de um desdobramento do poema "Estória do Aparelho azul-pombinho", ambos publicados originalmente no primeiro livro da autora: Poemas dos becos de Goiás e estórias mais.

O primeiro elemento a ser abordado na análise dO Prato Azul-Pombinho diz respeito à arquitetura poética coralineana, e sob tal aspecto tocar-se-á inicialmente num ponto capaz de suscitar profícuas reflexões: sua narrativa poética e ou seu poema narrativo.

Em diversas ocasiões, Cora Coralina autodenominou-se "rapsoda goiana", termo que dialoga profundamente com seu desejo, manifestado no início do livro Poemas dos becos de Goiás e estórias mais (1965), e já mencionado na Introdução desta tese, em que a autora, e não o "eu" poético, dirige-se diretamente ao leitor.

\footnotetext{
${ }^{10}$ Além do Papa (Pio XII), vários políticos e intelectuais brasileiros apreciaram seus doces. Muitos foram até Goiás e conheceram a poeta doceira de perto, como a Primeira Dama da Nação, dona Yolanda Costa e Silva, o médium Chico Xavier, as escritoras Rachel de Queiroz e Dinah Silveira de Queiroz. Os doces também motivaram o primeiro contato entre Cora Coralina e Jorge Amado (...) (BRITTO; SEDA, 2009, p. 289)
} 
Tal característica revela dois traços peculiares da obra de Cora Coralina: a preocupação com o resgate histórico da memória e, com a mesma intensidade, a valorização das questões culturais ligadas, essencialmente, ao folclore e às tradições populares.

Entretanto, apesar de manifestar preocupações que direcionaria o leitor, até com certa facilidade, para o texto em prosa, Cora Coralina escolhe (ou é escolhida) o texto poético. E não se trata simplesmente de questões de forma, pois tanto as estórias exalam poesia quanto os poemas exalam estórias, presentificando, assim, situações, lugares, pessoas e objetos de outrora. Dessa forma, do ponto de vista da estética coralineana, entende-se também

\footnotetext{
O ritmo de sua poesia, que combina versos longos modalizados na prosa com versos entrecortados, duros e secos. Seus procedimentos retóricodiscursivos são simples, têm na coloquialidade fonte prodigiosa, com recorrência de metáforas praesentia e comparações. Elementos da oralidade estão presentes na organização dos poemas, na forma agregativa dos versos, no tom de conversa e extensão. O modus operandi, baseado no vai e vem, fluxo e refluxo da fala, assenta-se na repetição, no paralelismo, nos adjetivos que vão se acumulando e dando volume aos poemas. (...) A mescla do épico e do lírico é outra característica de sua poética. (CAMARGO, 2006, p. 66-67)
}

A definição sobre a construção estética de Cora Coralina, feita por Goiandira Ortiz de Camargo diz muito acerca da postura da autora diante de sua própria produção, escapando prontamente de quaisquer rótulos que possam remeter a questões de forma ou ainda de gênero.

A própria autora, no primeiro texto poético de sua primeira obra publicada, demonstra desejar deixar claro o modo como se posiciona esteticamente. O título Ressalva - já diz muito a respeito disso, e não seria incorreto inferir que, por meio da última estrofe, Cora Coralina corrobora definitivamente a postura de "rapsoda goiana", que permeará toda a sua obra:

\section{(...)}

Este livro:

Versos... Não.

Poesia... Não.

Um modo diferente de contar velhas estórias.

(CORALINA, 2014, p. 27) 
O "modo diferente de contar velhas estórias" de Cora Coralina está presente nO Prato Azul-Pombinho e denota, além da tentativa de fugir de quaisquer engessamentos de sua obra, uma busca consciente pelo deslimite na composição de sua produção textual.

Não se trata, portanto, de poesia ou prosa - conto, crônica, fábula, romance, etc. - mas, sobretudo, de produzir o texto com poeticidade, entendendo "a poesia não apenas como um modo de expressão literária, mas como um estado segundo do ser que advém da participação, do fervor, da admiração, da comunhão, da embriaguez, da exaltação e, obviamente, do amor, que contém em si todas as expressões desse segundo estado." (MORIN, 2008, p. 09)

E é por meio desse amor, que contém em si todas as expressões desse estado de transcendência do ser, que Cora Coralina (re)constrói em seu texto poético o imaginário cultural dela e, por consequência, o do leitor, permitindo-Ihe reconhecer a presença do outro em si e vice-versa, não apenas do ponto de vista cultural, mas também, e acima de tudo, humano.

Isso porque a obra $O$ Prato Azul-Pombinho traz uma narrativa poética de amor, não só entre as personagens - a princesinha Lui e o príncipe $\mathrm{Li}$ - mas também e, sobretudo, entre uma bisneta e sua bisavó, entre uma menina e o prato que a remetia a um tempo áureo, que, embora às vezes severo, era dotado de profunda beleza. Esses elementos dialogam profundamente com a afirmação de Edgar Morin, em sua breve e intensa obra Amor, Poesia, Sabedoria:

Se o amor expressa o ápice supremo da sabedoria e da loucura, é preciso assumir o amor.

Se a poesia transcende sabedoria e loucura, é necessário aspirarmos a viver o estado poético e assim evitar que o estado prosaico engula nossas vidas, necessariamente tecidas de prosa e poesia. (MORIN, 2008, p. 09 e 10)

O caráter amoroso mencionado acima sobrepõe-se ao caráter técnico propriamente dito da arquitetura poética, o que, no caso da literatura infantil e mais especificamente da referida obra, constitui uma característica extremamente positiva, primeiro porque "não se pode esquecer que toda técnica "é neutra; que não é a presença de determinado recurso expressivo que dá o valor definitivo de um texto ou uma obra" (COELHO, 1982, p. 152), segundo porque "a mensagem poética 
deve atuar muito mais sobre as sensações da criança do que sobre seu entendimento" (COELHO, 1982, p. 152).

Daí também considerar a presença de um caráter ancestral capaz de tocar crianças, jovens e adultos não apenas nO Prato Azul-Pombinho, mas em toda a obra coralineana, mesmo que o poema narrativo não seja considerado "dos mais aconselháveis para despertar o gosto da criança pelo poético" (COELHO, 1982, p. 152) num primeiro momento, como destaca a professora Nelly Novaes Coelho.

Todavia, mais adiante, ela mesma não deixa de reconhecer que "há inúmeros poemas narrativos que "falam" de perto" (COELHO, 1982, p. 152) ao público infantil. É a essa seara que se defende pertencer toda a obra de Cora Coralina voltada para o público infantil.

Nesse contexto, o que torna O Prato Azul-Pombinho especial é a atmosfera metaforicamente criada pelo "eu" poético de uma infância em que a casa da avó no caso do "eu" poético, a casa da bisavó - é apresentada quase como um templo sagrado, ou ainda sob uma atmosfera onírica de onde as histórias parecem misteriosamente brotar, desde tempos imemoriais, por meio da recorrente expressão: "Minha bisavó (...) sempre contava e recontava (...)" (CORALINA, 2015, p. 05).

Daí a relação simbiótica mencionada anteriormente, que não poderia ser diferente, uma vez que Cora Coralina fez da sua vida açúcar, poesia, causos do seu Goiás, elementos capazes de nos remeter a um Brasil tão distante e, ao mesmo tempo, tão familiar, dada sua proximidade do nosso imaginário cultural.

Sob esse prisma, a poesia de Cora Coralina é capaz de despertar no leitor situações guardadas nos recônditos de sua alma, reminiscências profundas que, na maioria das vezes, roubam um sorriso dos lábios, como quando se prova aquele doce que se costumava comer na infância. Interessante pensar que parece ser exatamente esse o desejo dela.

Na concepção da obra O Prato Azul-Pombinho, Cora Coralina antecipara o valor que atribuía às questões ligadas à constituição do imaginário infantil. A primeira estrofe do poema exemplifica o apontamento inicial:

Minha bisavó - que Deus a tenha em glória sempre contava e recontava

em sentidas recordações

de outros tempos 
a estória de saudade

daquele prato azul-pombinho.

Era uma estória minuciosa.

Comprida, detalhada.

Sentimental.

Puxada em suspiros saudosistas

e ais presentes.

E terminava, invariavelmente,

depois do caso esmiuçado:

"- Nem gosto de lembrar disso..."

É que a estória se prendia

aos tempos idos em que vivia

minha bisavó

que fizera deles seu presente e seu futuro.

(CORALINA, 2011, p. 05)

A evocação da bisavó, contadora e fonte inesgotável de histórias impregnadas de História, todas inspiradas num passado permeado de aventuras e personagens de toda sorte que, em tempos idos, fizeram parte não apenas do cotidiano da infância da autora, mas também do cotidiano de um país.

Verso a verso, no decorrer das duas primeiras estrofes, o "eu" poético, ao resgatar uma gama de sentimentalidades ligadas à performance da bisavó - Puxada em suspiros saudosistas / e ais presentes. - captada pela criança ali presente, instiga nossa memória a resgatar a ancestralidade que compõe nossa essência, contribuindo, subjetivamente, para com a formação de nossa identidade.

Evidentemente que nesse e nos próximos casos, a referência é feita ao contato de um jovem ou mesmo de um adulto com a obra, cujas memórias da infância já existem. Entretanto, em se tratando da criança, como se mencionou na Introdução, por se defender que a linguagem poética pode contribuir significativamente para sua formação cultural e identitária, coaduna-se com a afirmação de Alfredo Bosi. Segundo ele,

A linguagem indica os seres ou os evoca. (...) o que importa apreender é a diferença específica dos modos imagético e linguístico de acesso ao real; diversidade que se impõe apesar da semelhança do fim: presentificar o mundo. (BOSI, 1977, p. 22)

Outro adendo que não poderia deixar de ser mencionado, antes de se progredir com a análise, diz respeito ao fato de que a escola ainda se configura como principal espaço de acesso de crianças e jovens à literatura infantil e juvenil. Sob esse prisma, não se deve ignorar que "(...) a educação formal deve partir de um 
lugar cultural conhecido pelo aluno para que se possam inserir novas possibilidades de uso da linguagem e ampliar sua competência discursiva e textual." (GREGORIN FILHO, 2009, p. 57).

Para que o ambiente escolar possa de fato atender ao que se espera de um espaço onde crianças e jovens tenham a possibilidade de se desenvolver, o primeiro passo deve ser o reconhecimento da relevância da poesia no processo de formação cultural do aluno; apenas assim será possível extrair do texto poético sua máxima potência artística, estética, simbólica.

É importante reconhecer ainda que, para a obra poética destinada a crianças e jovens atender ao que esta pesquisa propõe, é preciso que a escritura literária, especialmente na Literatura infantil e juvenil, seja compreendida por aqueles que a manuseiam, segundo a concepção de Roland Barthes, ou seja, como "uma imaginação ávida de felicidade das palavras; precipita-se para uma linguagem sonhada cujo frescor, por uma espécie de antecipação ideal, representaria a perfeição de um novo mundo adâmico, em que a linguagem não mais seria alienada" (BARTHES, 1971, p. 106)

Postas tais questões, dando continuidade à análise da obra $O$ prato azulpombinho destaca-se a opção que Cora Coralina faz pelo texto poético para contar uma história de sua infância. A essência da linguagem, da vida e do tempo reside na voz que o "eu" poético dá à sua bisavó. Esta, apesar de se referir a um passado distante na primeira estrofe, destaca, na estrofe seguinte, que, por meio desse mesmo passado, era dada a ela a possibilidade de construir o presente e o futuro.

Interessante que o exercício da bisavó de (re)contar a própria história para o "eu" poético, de modo esmiuçado e minucioso, garantia a ela - bisavó - não apenas a atemporalidade da história, como também a atemporalidade de si mesma, uma vez que seu imaginário a levava a reviver com intensidade similar todos aqueles acontecimentos.

Nada é mais contemporâneo do que o recurso utilizado pelo "eu" poético coralineano, uma vez que o leitor, ao se deparar com a obra, ainda em seu início, tem a possibilidade de experimentar um presente que

(...) não é outra coisa senão a parte de não-vivido em todo vivido, e aquilo que impede o acesso ao presente é precisamente a massa daquilo que, por alguma razão (o seu caráter traumático, a sua extrema proximidade), neste não conseguimos viver. $A$ atenção dirigida a esse não-vivido é a vida do 
contemporâneo. E ser contemporâneo significa, nesse sentido, voltar a um presente em que jamais estivemos. (AGAMBEN, 2009, p. 70)

Tal definição mostra que o cenário construído pelo "eu" poético já no início da obra pode proporcionar ao leitor uma viagem metafórica, independentemente da realidade em que ele esteja inserido, ou seja, mesmo uma criança, na era digital, em pleno século $\mathrm{XXI}$, pode ser transportada poeticamente para o lugar ocupado pelo "eu" poético, ou seja, diante de sua bisavó.

Segue-se a este relato inicial uma descrição do prato azul-pombinho exatamente como o "eu" poético dissera que seria nos cinco primeiros versos da segunda estrofe: (...) estória minuciosa / Comprida, detalhada. / Sentimental. / Puxada em suspiros saudosistas / e ais presentes.

Cora Coralina transcende a descrição pura e simples de um objeto, porque, além de utilizar-se dos recursos linguísticos e literários propriamente ditos que, de certa forma, são comuns e aplicáveis a qualquer estrutura poética (metáforas, sinestesias, metonímias, etc.).

Dessa forma, não seria incorreto inferir que a poeta "trabalha o signo verbal" (2005, p.10), de modo a proporcionar porções sentimentais de ilimitada grandeza a história, seja pela manifestação do saudosismo da bisavó, seja pelo relato do amor proibido dos amantes, seja ainda pelo sentimento que o "eu" poético nutria pelo prato azul-pombinho.

Há, nO Prato Azul-Pombinho, e por que não dizer na obra coralineana, a presença de uma das principais características necessárias para que uma obra esteja inserida no novo milênio. É a referência à Leveza na escrita que, segundo Ítalo Calvino, "(...) é algo que se cria no processo de escrever, com os meios linguísticos próprios do poeta, independentemente da doutrina filosófica que este pretenda seguir." (1990, p. 22).

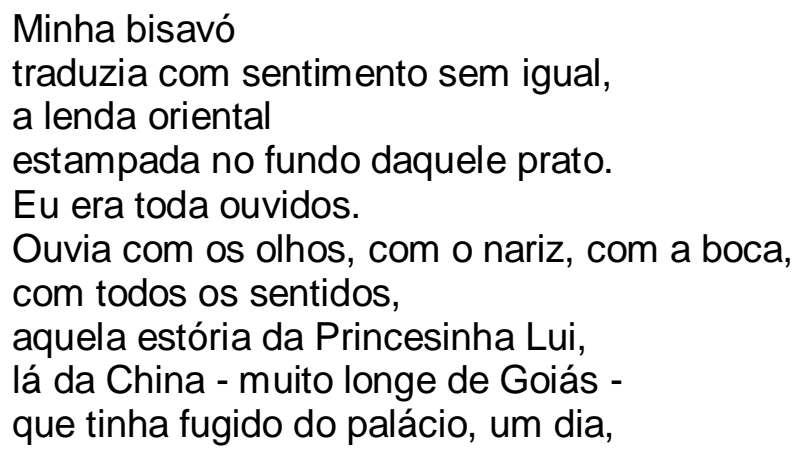


com um plebeu do seu agrado

e se refugiado num quiosque muito lindo

com aquele a quem queria,

enquanto o velho mandarim - seu pai -

concertava, com outro mandarim de nobre casta,

detalhes complicados e cerimoniosos

do seu casamento com um príncipe todo-poderoso,

chamado Li. (CORALINA, 2011, p. 10)

Nesse sentido, ao privilegiar o amor, a poeta proporciona uma leitura do texto muito mais apetecível ao leitor, pois com tais doses de sentimentos potencializadas pela estética da descrição, privilégio do texto poético, é possível abrandar o peso da realidade, tornando-a suportável, afinal não nos esqueçamos de que

\begin{abstract}
Escreve-se "sobre" a realidade ou se escreve "a" realidade? Se admitirmos que se escreve "a", que dizer da sua leitura - a leitura, por exemplo, de um poema? O que, nela, nos toca? Não mais que a "escrita" da realidade? Mas que é mesmo a "realidade"? A "realidade" é alguma coisa posta entre aspas. (BRASILEIRO, 2002, p. 151)
\end{abstract}

Com o arrebatamento provocado pela atmosfera poético-narrativa visualizase, quase no final da história, a destruição física do prato azul-pombinho seguida da confirmação de que ele já residia no imaginário infantil, na essência, na identidade não mais apenas do "eu" poético, mas também de todos os leitores, que a essa altura já aprenderam a amar, com o mesmo fervor, o prato azul-pombinho.

É preciso destacar também que a poeta insere nas estrofes acima dois aspectos relevantes que permearão toda a obra. O primeiro aponta o modo como o "eu" poético, enquanto interlocutor da bisavó, recebe as informações. Tal recepção mais intuitiva, sensorial do que racional, intelectual, simboliza grandemente o modo como a criança percebe o mundo ao seu redor: Eu era toda ouvidos. / Ouvia com os olhos, com o nariz, com a boca, / com todos os sentidos.

O segundo aspecto, também relacionado a essa maneira de "ouvir" descrita pelo "eu" poético, dialoga fortemente com o modo como a poesia deve ser oferecida à criança - explorando a concretude da palavra poética -, potencializando na contemporaneidade a percepção desta acerca do mundo a sua volta. Nesse sentido, a construção poética dO Prato Azul-Pombinho oferece ao leitor, no interior do processo narrativo, elementos essencialmente poéticos, dotados de sonoridade, ritmo, musicalidade e sinestesias.

José Nicolau Gregorin Filho sinaliza tal importância, salientando que 
Quando oferecemos um poema para a criança ler, é importante fazê-la tomar contato com a concretude da palavra poética, isto é, primeiro observa-se o trabalho com a palavra, sua sonoridade, seu ritmo e toda a musicalidade que o poema pode proporcionar. E aqui não se diz apenas de textos rimados como eram oferecidos antigamente; é importante que a criança perceba a musicalidade do verso livre, a escolha precisa das palavras para que se tenha um sentido único em determinado texto, a liberdade de criar, seja o criador o produtor do texto propriamente dito ou 0 leitor. (GREGORIN FILHO, 2011, p. 75)

Além de atender esteticamente às especificidades do público a que se destina, do ponto de vista temático, como se mencionou anteriormente, Cora Coralina, ao abordar uma história de amor proibido entre uma princesa e um príncipe, aproxima-se significativamente dos enredos dos contos de fadas, por exemplo, evidenciando também a existência do que há de universal na obra, isto é, a aproximação, ou melhor, o entrelaçamento de culturas distantes por meio da arte.

A distância geográfica, sinalizada pelos versos - aquela estória da Princesinha Lui, / lá da China / muito longe de Goiás - é trabalhada poeticamente de modo a importar muito pouco para a criança. Cora Coralina articula o texto valorizando o que une o ser humano e não o que o separa: a necessidade ancestral de contar e ouvir histórias. O que é perfeitamente apreendido pela criança, mesmo intuitivamente, uma vez que

O inconsciente humano encerra todas as formas de vida e de funções herdadas da ascendência ancestral, de forma que a criança já nasce com uma disposição psíquica funcional, adequada, anterior à consciência. Portanto, não é uma tabula rasa. (Almeida, 2018, p. 70)

Uma vez mergulhados no texto, o "eu" poético apresenta a sua dor, e os leitores são submetidos, verso a verso, àquela emoção minuciosamente exposta, que os incita a chorar, ficando com os argumentos embargados, e, ao se solidarizarem, como cúmplices, são condenados...

Eu (emocionada) vendo o pranto de minha bisavó, lembrando só da princesinha Lui -

que já tinha passado a viver no meu inconsciente

como ser presente,

comecei a chorar

- que chorona sempre fui.

Foi o bastante para ser apontada e acusada

de ter quebrado o prato. 
Chorei mais alto, na maior tristeza,

comprometendo qualquer tentativa de defesa.

De nada valeu minha fraca negativa.

Fez-se o levantamento de minha vida pregressa

de menina

e a revisão de uns tantos processos arquivados.

Tinha já quebrado - em tempos alternados,

três pratos, uma compoteira de estimação,

uma tigela, vários pires e a tampa de uma terrina. (CORALINA, 2011, p. 26)

Interessante pensar que a decisão acerca da punição a ser aplicada à ré é ponderada pela mesma bisavó, a outra personagem que, juntamente com o "eu" poético, era a que mais amava o prato azul-pombinho. Fora um castigo aplicado por quem possuía a prerrogativa de amar primeiro, decisão matriarcal, que objetivava condenar e expor a falta, para que servisse de lição a todos.

Entretanto o que era para ser doloroso para a vida inteira cristalizou-se numa doce lembrança "no armarinho da memória (...)" (CORALINA, 2011, p. 33). Esse final traduz, com grande beleza, o quanto o imaginário infantil, aquele que está guardado no mais íntimo do ser, pode ser despertado pela poesia, materializando impressões, lembranças, sensações, constituindo assim identidades, entendendo-se aqui como beleza "(...) a face pela qual a natureza se torna admirável; o meio da ratificação do real pela sensibilidade." (LE SENNE, p. 215, 1965).

\footnotetext{
Chorei sozinha minhas mágoas de criança.

Depois me acostumei com aquilo.

No fim, até brincava com o caco pendurado.

$E$ foi assim que guardei

no armarinho da memória, bem guardado,

e posso contar aos meus leitores,

direitinho,

a estória, tão singela,

do prato azul-pombinho. (CORALINA, 2011, p. 33)
}

Destaca-se no final dessa narrativa poética a vivacidade presente na riqueza dos detalhes e sobretudo na ternura construída pelo "eu" poético, ainda que por meio de uma linguagem coloquial, simples, às vezes com palavras no diminutivo armarinho, direitinho - como faziam as avós, com versos livres, sem rima, mas costurados por um enredo capaz de permitir privilegiada visibilidade de uma época ancestral que, ainda no século XXI, reside em todos, pois 
(...) diversos elementos concorrem para formar a parte visual da imaginação literária: a observação direta do mundo real, a transfiguração fantasmática e onírica, o mundo figurativo transmitido pela cultura em seus vários níveis, e um processo de abstração, condensação e interiorização da experiência sensível, de importância decisiva tanto na visualização quanto na verbalização do pensamento. (CALVINO, 1990, p.110)

Não se poderia deixar de mencionar a NOTA final da obra: "De como acabou, em Goiás, o castigo dos cacos quebrados no pescoço" (Anexo II). Nela, Cora Coralina tece uma narrativa poética impregnada de história, beleza e tristeza, simultaneamente, isto porque não objetiva apenas informar, o que é próprio das notas, mas aguçar o imaginário do leitor, provocando-Ihe sensação de que ainda estão inseridos naquele universo literário.

A referida história é quase um continuum. Diz-se quase porque ela retomará a história do prato azul-pombinho apenas na sua parte final; até então, a autora esclarece a história do castigo aplicado ao "eu" poético.

A NOTA funciona como uma matryoshka no contexto geral da obra e surpreende pelos seguintes fatores: a) pela estética, ou seja, uma construção puramente narrativa depois de uma narrativa poética; b) pela temática mais voltada para o social, com destaque para a riqueza nos detalhes da relação escravagista; c) por tocar na questão pedagógica, seja por meio da busca pela educação formal por parte da personagem Jesuína, seja pela postura de aprovação das famílias no que concerne à aplicação de castigos severos.

Pode-se afirmar ainda, no tocante ao último item, que Cora Coralina conhecia de perto o mecanismo de funcionamento das questões ligadas à formação do indivíduo, até porque havia um diálogo profundo entre a severidade com que se tratava a personagem principal e a dinâmica escolar da época, pois a "história da escola é marcada por influências religiosas/moralizantes, e passa-se a reservar a essa instituição a incumbência de preparar a criança para o convívio com os adultos. (MAGNANI, 2001, p. 71)". A NOTA é encerrada com a aproximação entre Aninha e o "eu" poético, permitindo ao leitor uma relação intertextual imediata.

Cora Coralina encerra a obra O Prato Azul-Pombinho posicionando as duas histórias, criando uma unidade literária, proporcionando assim uma viagem estética, simbólica, sinestésica, entre China e Goiás, entre o amor de uma bisneta e sua bisavó, entre o amor de uma criança por uma história, gravada num prato cuja 
significação transcendeu o objeto propriamente dito, metamorfoseando um simples caco em pura poesia.

\section{2 - O Poema do milho: retrato poético-identitário de um Brasil profundo}

O Brasil é um país rural. Independentemente da abordagem e ou da área de pesquisa - Antropologia, Artes Plásticas, Economia, Filosofia, História, Sociologia, etc. - que se escolha, sempre se vai esbarrar com questões referentes a um contexto, via de regra, bucólico. A realidade campestre está intimamente ligada, até hoje, à constituição identitária do país.

No campo da Arte e, mais especificamente, da Literatura não é diferente, ao longo da história do país e, independentemente do movimento a que pertenciam, escritores produziram obras, desenharam cenários, criaram personagens e construíram poemas cujas temáticas ligadas a questões rurais, direta ou indiretamente, sempre se fizeram presentes.

A Literatura infantil e juvenil brasileira não fugiu a essa característica, pois desde Monteiro Lobato, com seu Sítio do pica-pau amarelo por exemplo, inúmeras obras trazem, em sua arquitetura verbal, elementos capazes de evocar culturalmente um Brasil que, embora pareça distante do contexto das grandes metrópoles do país na contemporaneidade, está muito próximo do Brasil denominado nesta tese de profundo, longe das capitais e das experiências urbanas a elas subjacentes, onde ainda ecoam costumes, símbolos e valores que remontam ao século XIX.

É preciso lembrar que a obra Poema do Milho é composta por dois poemas: "Oração do Milho" e "Poema do Milho"; ambos publicados originalmente na obra Poemas dos Becos de Goiás e estórias mais em 1964. A clara relação temática e o fato de o primeiro poema ser colocado como "Introdução ao Poema do Milho" justificam a posterior reunião desses poemas na obra infantil.

Embora publicado no início do século XXI, pode-se perceber nitidamente que, em Poema do milho, Cora Coralina atende às questões que ecoam nesse Brasil profundo, desde a influência religiosa, herança de nossa formação judaico-cristã devida aos jesuítas, até o desenho poético do processo de plantio e colheita do milho, comum nos interiores do Brasil. 
A presença de questões religiosas e rurais na poesia de Cora Coralina pode ser atribuída à íntima relação biográfica que a autora possui, desde sua infância na Fazenda Paraíso, em Goiás, até o período em que viveu no interior de São Paulo, mais especificamente nas cidades de Penápolis ${ }^{11}$ e Andradina ${ }^{12}$. Isso explica como nO Prato Azul-Pombinho, as reminiscências de outrora influíram diretamente na produção poética coralineana.

Tal propagação de "um maniqueísmo fortemente marcado e dos valores de um país que lutava pela busca de sua identidade, que procurava ser valorizado enquanto nação" (GREGORIN FILHO, 2009, p. 25), traçados nessa obra, foi comum no Brasil do início do século XX nas casas e nas escolas, graças à distribuição de obras como Coração ${ }^{13}$ do italiano Edmundo de Amicis ${ }^{14}$.

Nesse sentido, considerando que no "homem de hoje, perduram lado a lado o mágico e o lógico, fazendo ver que, ao menos sob esse aspecto, as mentalidades de todos os homens têm a mesma base essencial" (CÂNDIDO, 1985, p. 43), não seria incorreto inferir que, por meio da obra Poema do Milho, Cora Coralina colabora significativamente para a construção e ou consolidação do retrato poético-identitário de um Brasil profundo.

Sob esse prisma, quando se pensa em Literatura infantil e juvenil oferecida, ou não, nas escolas, entende-se que tal colaboração artística transcende o caráter pedagógico propriamente dito. Não se trata apenas de formar 0 aluno academicamente, do ponto de vista do aguçamento da percepção estética, e ou dos

\footnotetext{
${ }^{11}$ A cidade propiciou que Cora Brêtas entrasse em contato com os franciscanos. Mesmo sendo leiga, ela quis vivenciar os ensinamentos do Irmão Francisco. Todos que ingressam nessa cristantade perseguem um ideal de santidade. Foi nesse intuito que Cora, em 19 de novembro de 1937, fez parte da Venerável Ordem Terceira da Penitência Franciscana (...) recebeu o nome de Irmã Conceição. (...) passou a ser penitente. Ela, que já mostrava amor à irmã pobreza, decidiu-se tornar uma franciscana. (...) depois de entrar para a Ordem, passou a utilizar roupas que haviam sido usadas e, em casa, vestia as roupas mais surradas. (BRITTO; SEDA, 2009, p. 192, 193)

${ }^{12}$ No dia de seu 52을 aniversário, 20 de agosto de 1941, Cora Brêtas adquiriu do amigo Manoel Francisco dos Santos um pedaço de terra: 25 alqueires paulistas, pela quantia de sete contos de réis. Surgia a Cora Coralina sitiante... a mulher Terra! Chamada pelos mais íntimos de dona Cora Brêtas, ou somente dona Cora. (...) A terra era limpa e, no tempo certo, arada e semeada. Tempo das águas. Plantou milho e, ali, colheu dois de seus poemas mais celebrados: "Oração do Milho" e "Poema do Milho". (BRITTO; SEDA, 2009, p. 206 e 208)

${ }^{13}$ Escrita em 1886, a obra foi divulgada pelo mundo em milhares de edições, conquistando leitores de todas as idades e classes sociais. Só na Itália, conta com mais de um milhão de exemplares vendidos. (...) No Brasil, Valentim Magalhães, em 1891, elabora sua tradução (...) Dessa data em diante, Coração invade as escolas brasileiras e os lares nacionais, passando a ser lido por todos, independentemente da faixa etária e condição social. (GREGORIN FILHO, 2009, p. 23)

${ }_{14}$ Edmundo de Amicis foi um escritor italiano mundialmente conhecido. Natural de Oneglia, nasceu em 1846 e faleceu em 1908, deixando variada obra em que se destacam narrativas de viagens, crítica literária, novelas, livros de temas sociais e políticos. (GREGORIN FILHO, 2009, p. 23)
} 
aspectos formais da obra, ou ainda de sua análise semântica e contextual; mas de inseri-lo humana e culturalmente no universo identitário de seu país, valendo-se da linguagem poética para nutrir o seu imaginário.

Diante de tais questões, defende-se nesta tese que, no Poema do Milho, Cora Coralina atende, entre outros aspectos abordados mais adiante, uma das mais nobres funções do poeta segundo Décio Pignatari. Para ele, o poeta:

(...) é aquele que ajuda a fundar culturas inteiras. Não dá para entender a cultura portuguesa sem Camões; a inglesa sem Shakespeare; a italiana sem Dante; a alemã sem Goethe; a grega sem Homero; a irlandesa sem Joyce. (PIGNATARI, 2005, p. 10)

A poesia de Cora Coralina, nesse processo de "ajudar a fundar culturas inteiras" pode, por meio da obra Poema do Milho, proporcionar ao leitor a possibilidade de compreensão de sua cultura, começando pela observação do primeiro poema do livro - Oração do Milho - que, como fora citado anteriormente, é colocado na obra como uma "Introdução ao Poema do Milho".

Nela, de modo sintético, o "eu" poético é o próprio milho dirigindo-se ao divino, adotando uma postura de gratidão acerca de sua origem, entretanto há nessa oração elementos que resplandecem a ancestralidade da formação cultural do Brasil.

\section{Oração do Milho}

Senhor, nada valho.

Sou a planta humilde dos quintais pequenos e das lavouras pobres.

Meu grão, perdido por acaso,

nasce e cresce na terra descuidada.

Ponho folhas e haste, e se me ajudardes, Senhor, mesmo planta de acaso, solitária, dou espigas e devolvo em muitos grãos o grão perdido inicial, salvo por milagre, que a terra fecundou.

Sou a planta primária da lavoura.

Não me pertence a hierarquia tradicional do trigo e de mim não se faz o pão alvo universal. O Justo não me consagrou Pão da Vida, nem lugar me foi dado nos altares. Sou apenas o alimento forte e substancial dos que trabalham a terra, onde não vinga o trigo nobre. Sou de origem obscura e de ascendência pobre, alimento de rústicos e animais do jugo.

Quando os deuses da Hélade corriam pelos bosques, coroados de rosas e de espigas, quando os hebreus iam em longas caravanas 
buscar na terra do Egito o trigo dos faraós, quando Rute respigava cantando nas searas de Booz e Jesus abençoava os trigais maduros, eu era apenas o bró nativo das tabas ameríndias.

Fui o angu pesado e constante do escravo na exaustão do eito. Sou a broa grosseira e modesta do pequeno sitiante.

Sou a farinha econômica do proletário.

Sou a polenta do imigrante e a miga dos que começam a vida em terra estranha.

Alimento dos porcos e do triste mu de carga.

O que me planta não levanta comércio, nem avantaja dinheiro.

Sou apenas fartura generosa e despreocupada dos paióis.

Sou o cocho abastecido donde rumina o gado.

Sou o canto festivo dos galos na glória do dia que amanhece.

Sou o cacarejo alegre das poedeiras à volta dos seus ninhos.

Sou a pobreza vegetal agradecida a Vós, Senhor,

que me fizeste necessário e humilde.

Sou o milho.

(CORALINA, Cora, 2011, p. 04-06-07)

Numa obra para leitura da criança, a presença de seres e elementos maravilhosos, místicos, míticos, folclóricos não são novidade; constituem inclusive, na maioria dos casos, o fio condutor das histórias, independentemente do gênero em que são produzidas - romances, novelas, contos, cantigas, poesias, entre outros - e ou do período histórico a que pertençam.

Em se tratando da história da Literatura infantil no Brasil, temos, de modo marcante, desde o Brasil-Colônia até o início do século XX, a presença direta e ou indireta de preceitos religiosos judaico-cristãos, com o intuito de, por meio da religiosidade e do moralismo, educar pela exemplaridade e doutrinação aquele ser humano em formação, enxergado até então como um adulto em miniatura.

De certa forma, a "Oração do Milho" não foge a esse viés histórico, o "eu" poético coralineano faz claras referências ao cristianismo já na primeira estrofe, não só pelo tom confessional adotado desde o início pelo "eu" poético, mas também ao se colocar em posição inferior ao trigo, por exemplo: Não me pertence a hierarquia tradicional do trigo / e de mim não se faz o pão alvo universal. / o Justo não me consagrou Pão da Vida, / nem lugar me foi dado nos altares.

Entretanto trata-se de uma oração cujos valores manifestados são a humildade, a simplicidade e a gratidão, ecoando uma cultura popular muito comum nos interiores do Brasil, a de se colocar diante do Divino como aquele que, desprovido de toda e qualquer nobreza e ou sofisticação, apenas reconhece sua pequenez e agradece ou mesmo pede, ainda que se achando indigno. Há exemplos 
similares na música popular brasileira, como na música "Romaria" de Renato Teixeira ou "Súplica cearense" de Gordurinha e Nelinho.

Além disso, Cora Coralina evoca ainda outro aspecto comum na cultura popular dos interiores do país, uma vez que

Uma oração precede ou finaliza um acontecimento. Ora-se para pedir ou para agradecer. E dona Cora antecedeu o "Poema do Milho" com a "Oração do Milho", relembrando a irmã franciscana que vivia dentro dela (...). (BRITTO; SEDA, 2009, p. 208)

O que se quer dizer é que, ao preterir os moldes solenes, comumente utilizados no tom da composição das orações, em favor da estrutura poética e da temática mais popular, com uma abordagem mais cultural do que religiosa propriamente dita, Cora Coralina acaba dialogando - ainda que intuitivamente - com

“(...) o processo de mudança sofrido na concepção de literatura infantil, ou seja, de instrumento pedagógico de concepção moralizante do passado, ela passa a espelhar a sociedade com suas relações, necessidades, questionamentos e padrões estéticos. (GREGORIN FILHO, 2009, p. 36)

Outro adendo importante diz respeito ao fato de a poeta abrir mão, por assim dizer, da nobreza histórica que o milho possui, não remetendo nem de longe ao simples “(...) bró nativo das tabas ameríndias”. Ao contrário, segundo o Dicionário de Símbolos:

\begin{abstract}
Nas culturas mexicanas e relacionadas, o milho é ao mesmo tempo a expressão do Sol, do Mundo e o do Homem. No Popol Vuh, a criação do homem só é atingida depois de três tentativas: o primeiro homem, destruído por uma inundação, era feito de argila; o segundo, disperso por uma grande chuva, era feito de madeira; somente o terceiro é nosso pai: ele é feito de milho (ALEC, 116). Ele é o símbolo da prosperidade, considerada em sua origem: a semente. (CHEVALIER, GHEERBRANT, 2007, p. 610-611)
\end{abstract}

No caso do Brasil, tal importância não é minimizada; ao contrário, o milho até hoje representa não apenas fonte de sustento para pequenos produtores, como também movimenta fortunas no cenário agrícola nacional, sem contar que não pode ser desconsiderado seu valor simbólico, não apenas por sua raiz indígena, mas, sobretudo, por constituir historicamente uma das principais fontes de alimento de nosso país, saciando a fome das pessoas, independentemente da classe social a que pertençam. 
Ao optar pela não abordagem da riqueza simbólica e cultural do milho para os povos ameríndios, de modo a valorizar a nobreza desse vegetal, Cora Coralina, ao contrário, insere-o num contexto utilitário de simples serviços, de pobreza, de humildade, praticamente de subserviência, estabelecendo assim um rico diálogo com o universo histórico e cultural do interior do Brasil, constituído em grande parte de economias rurais de pequeno porte, talhado pelo trabalho rural intenso, desenhando poeticamente, na última estrofe, um retrato panorâmico - mas breve e intenso - de parte substancial da construção da história do Brasil sob o viés dos mais pobres.

Tal construção remete a um movimento espiralado centrípeto por meio das imagens, ou seja, a partir das metáforas, da personificação do cereal, pode-se evidenciar que 0 aspecto humano presente no "eu" poético coralineano, ao permitir a um cereal se dirigir ao divino em oração, atribui a ele, cereal, a mais humana das características: a de se conectar com o sagrado.

Nesse movimento e, apesar de toda riqueza simbólica em torno do milho, ao colocá-lo numa posição de subserviência e de humildade, Cora Coralina o aproxima do ideal cristão do homem que, apesar de concebido à imagem e semelhança do Altíssimo, quando diante deste, prostra-se reconhecendo sua pequenez, suas restrições e sua efemeridade, limitando-se apenas a agradecer e a se apresentar, desnudando-se:

\footnotetext{
Senhor, nada valho.

Sou a planta humilde dos quintais pequenos e das lavouras pobres.

(...)

Sou a pobreza vegetal agradecida a Vós, Senhor,

que me fizeste necessário e humilde.

Sou o milho. (CORALINA, Cora, 2011, p. 04-07)
}

Levando em consideração tais questões, defende-se que a "Oração do Milho", por passar, como mencionado acima, "a espelhar a sociedade com suas relações, necessidades, questionamentos e padrões estéticos. (GREGORIN FILHO, 2009, p. 36)", contribui grandemente para a formação cultural, humana e poética da criança.

Terminada a oração, Cora Coralina continua desenhando um retrato históricocultural-poético no poema que se segue na obra: "Poema do Milho"15. Contudo, dessa vez, não está mais em evidência a relação desse vegetal com o sagrado, mas

\footnotetext{
${ }^{15} \mathrm{O}$ poema na íntegra consta em anexo, mais especificamente no Anexo III.
} 
com o próprio interior do Brasil, onde o processo envolve, em síntese, a harmonia construída poeticamente entre o ritual do plantio e da colheita do milho e o processo de formação do homem.

A partir do desvelamento estético de circunstâncias ritualísticas e corriqueiras nos interiores do Brasil, a escritora oferece ao leitor a possibilidade de acessar elementos fulcrais na concepção identitária do país. O ritual de plantio e colheita do milho vivido pelo povo da roça se metamorfoseia numa experiência de caráter existencial que, de certa forma, paira em nosso inconsciente coletivo, como arquétipo de um contexto, ainda que distante, familiar, trazendo também a possibilidade de refletir sobre questões sociais, entre elas, o uso da terra.

Dessa forma, aceita-se que, em seu imaginário, cada criança

(...) traz ao nascer, sob a forma de estruturas mentais esboçadas a integralidade dos meios de que a humanidade dispõe por toda a eternidade para definir as suas relações com o mundo. Os valores culturais incidem sobre tais meios e, a partir dessa interação, os sujeitos constroem formas de ação e de pensamento. (GRANATO, 2000, p. 60)

A análise que se segue sinaliza que a composição poética de Cora Coralina em "Poema do Milho" pode instigar a criança, suscitando valores culturais e identitários presentes no imaginário coletivo do país e que, de certa forma, ecoam no imaginário individual.

Os primeiros versos do poema apresentam ao leitor, gradativamente, as várias possibilidades de cultivo desse valioso vegetal. O "eu" poético, atribuindo ao milho tamanha flexibilidade de cultivo - desde os quintais, roças e lavouras, até as divisas do país - evidencia sua presença e, consequente importância na concepção histórica, cultural e identitária do país, destacando, nos versos subsequentes, o milho e sua profusão de cores, tão diversa quanto a do nosso povo:

Milho...

Punhado plantado nos quintais.

Talhões fechados pelas roças.

Entremeado nas lavouras,

Baliza marcante nas divisas.

Milho verde. Milho seco.

Bem granado, cor de ouro.

Alvo. Às vezes varia,

- espiga roxa, vermelha, salpintada. (CORALINA, 2015, p. 08)

$(\ldots)$ 
As estrofes seguintes - apoiadas fortemente pelas ilustrações da obra darão conta de toda abundância contemplada pela produção do milho, especialmente nos pequenos roçados, onde, além do milho, ainda são cultivados costumes de outrora, como a celebração das colheitas e a reciprocidade entre os vizinhos no que concerne à troca de alimentos:

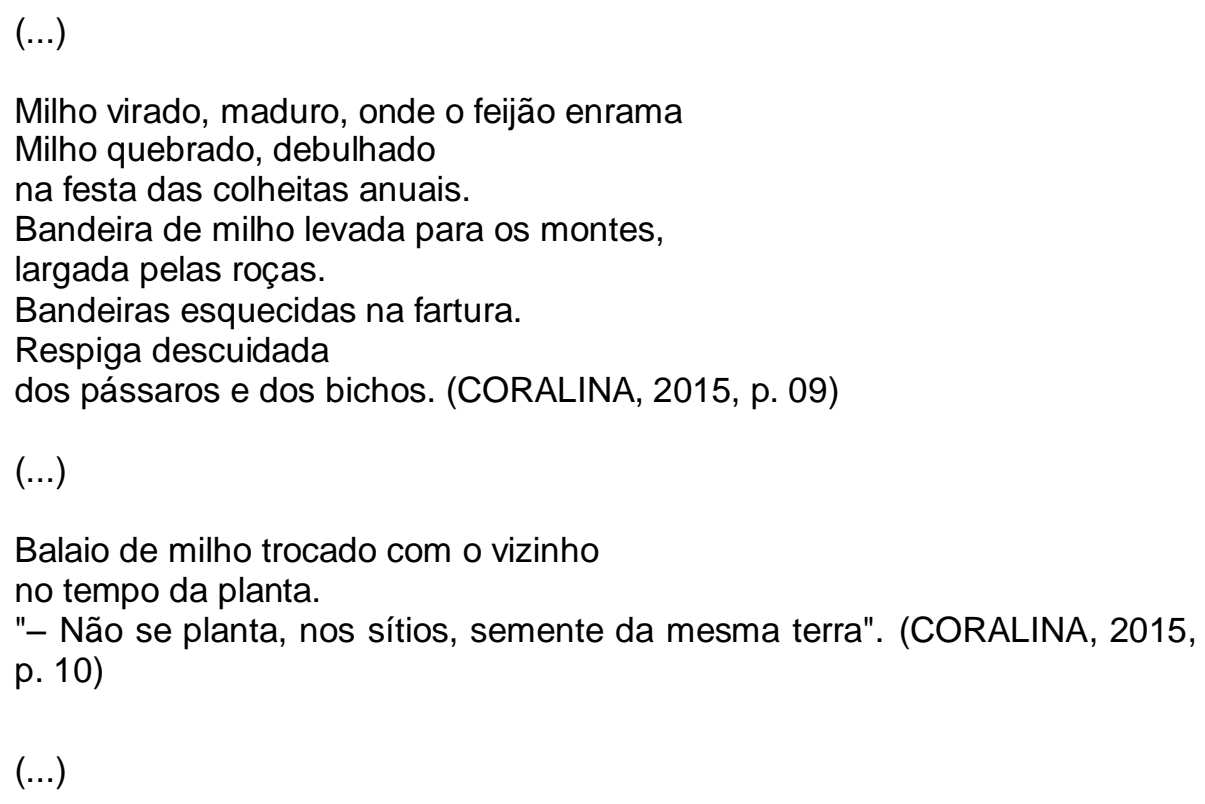

Elementos que evocam um Brasil ancestral, "profundo", como se mencionou no início da abordagem, não faltam ao "Poema do Milho". Cora Coralina, valendo-se de imagens que desenham o processo de manejo do milho - ultrapassado para o agronegócio contemporâneo, mas vivo nos pequenos roçados - oferece ao leitor uma experimentação poética, quase romântica, dessa vivência.

Defende-se que a vivência proporcionada pela experimentação poética à qual já houve referência no parágrafo anterior pode suscitar na criança mais do que o interesse pela cultura de seu país. O conjunto metafórico, sinestésico, polifônico presente na arquitetura verbal da obra permite ao leitor estabelecer contato com as raízes daqueles que, desde tempos imemoriais, constituíram e constituem a sociedade brasileira.

Por meio do "Poema do Milho", Cora Coralina transmite história, cultura, identidade e, por que não dizer, prazer. Assim, por se entender que a poesia opera por construções imagéticas, harmoniza-se com a afirmação de Maurice Blanchot. Segundo ele: 
(...) o que fala em nome da imagem, "ora" fala ainda do mundo, "ora" nos introduz no meio indeterminado da fascinação, "ora" nos concede o poder de dispor das coisas em sua ausência e pela ficção, retendo-nos assim num horizonte rico de sentido, "ora" nos faz resvalar para onde talvez estejam presentes, mas em suas imagens; (...) o sentido não é mais uma aparência, a aparência faz com que o sentido se torne infinitamente rico (...). (BLANCHOT, 1987, p. 265)

Com o intuito de ilustrar a teoria defendida nesta tese, subdividi-se o restante da análise do "Poema do Milho" em três partes, a saber: a) O plantio; b) O pendoar; c) A colheita.

\subsection{1 - O plantio}

Observar os fenômenos da natureza (relâmpagos, trovões, chuvas, etc.) e a posição dos astros, em especial da lua, considerando-os manifestações divinas, responsáveis pela manutenção da lavoura - qualquer que seja - remonta aos primórdios da história da agricultura na humanidade. Exigia sensibilidade do homem para perceber as nuances do tempo ao seu redor.

Barrufo de chuva.

Cheiro de terra; cheiro de mato,

Terra molhada, Terra saroia.

Noite chuvada, relampeada.

Dia sombrio. Tempo mudado, dando sinais.

Observatório: lua virada. Lua pendida...

Circo amarelo, distanciado,

marcando chuva.

Calendário, Astronomia do lavrador. (CORALINA, 2015, p. 12)

Além da apurada capacidade de percepção dos sinais emitidos pela natureza, era preciso, em respeito à Terra, obedecer aos rituais de plantio. O sistema velho colonial exige que o homem esteja em estado de comunhão com o meio ambiente que o cerca. Considera-se tal estado como poético à medida que "(...) pode ser produzido pela dança, pelo canto, pelo culto, pelas cerimônias e, evidentemente, pelo poema." (MORIN, 2008, p. 36).

Nesse aspecto, ao recorrer a uma abordagem ancestral em relação ao modo como o alimento é tratado, o "eu" poético de Cora Coralina atribui ao plantio do milho uma função redentora, aproximando-se mais do homem primitivo que do civilizado. 
Nesse cenário, o Homem é parte da Natureza e ela retribui a deferência com que é tratada fornecendo vida através do alimento, daí sua condição sagrada.

Assim, no "Poema do Milho", "o alimento pode desempenhar um papel genérico de "inspirador", de motor de outras emoções, - papel que, para o civilizado, é atribuído a outras realidades, como o amor, a natureza, Deus." (CÂNDIDO, 1985, p. 67-68), daí seu plantio ser descrito esteticamente pela poeta como um ritual sagrado:

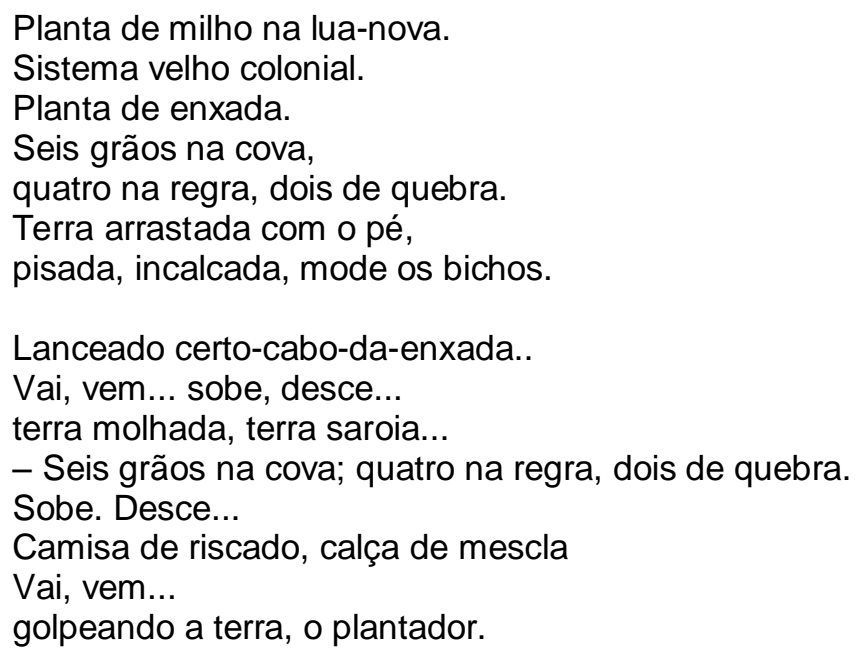

Na sombra da moita, na volta do toco - o ancorote - d'água. (CORALINA, 2015, p. 12-13)

Observando o ritual do plantio desenhado pelo "eu" poético no "Poema do Milho", defende-se que Cora Coralina, ao mesmo tempo que ressalta a identidade histórico-cultural cristã-católica, como se verá de modo explícito em versos apresentados mais à frente - talvez por seu tardio, mas relevante, ingresso na irmandade de São Francisco de Assis - não deixa de valorizar também a herança histórico-cultural indígena, de deferência à natureza, mais do que isso, de comunhão com ela.

Isso porque se entende que Cora Coralina, por destacar não só o valor simbólico, subjetivo do milho, mas, sobretudo, o valor físico, objetivo do alimento que nutre o corpo, atribui assim certa dose emocional ao poema, reforçando ainda mais o caráter primitivo mencionado anteriormente, e corroborando as considerações de Antônio Cândido. Este afirma que, enquanto

“(...) para o primitivo a emoção é condicionada por uma referência aos alimentos básicos (...) para o civilizado estes só vinculam ao universo da 
emoção estética se passarem por um processo de perda da sua realidade nutritiva." (CÂNDIDO, 1985, p. 68)

Nas três últimas estrofes que compõem o que se entende pertencer ao plantio, o "eu" poético, dirigindo-se ao cavador de milho, como se este fora o cavador de si mesmo, desvela o caráter ancestral da Terra. Entretanto, diferentemente do início, Cora Coralina prima pelo caráter filosófico, não desconsiderando o sagrado, salientando a ciclicidade da vida no ato contínuo de plantar e replantar, daí eclodir o estado poético - função última da poesia - segundo Edgar Morin.

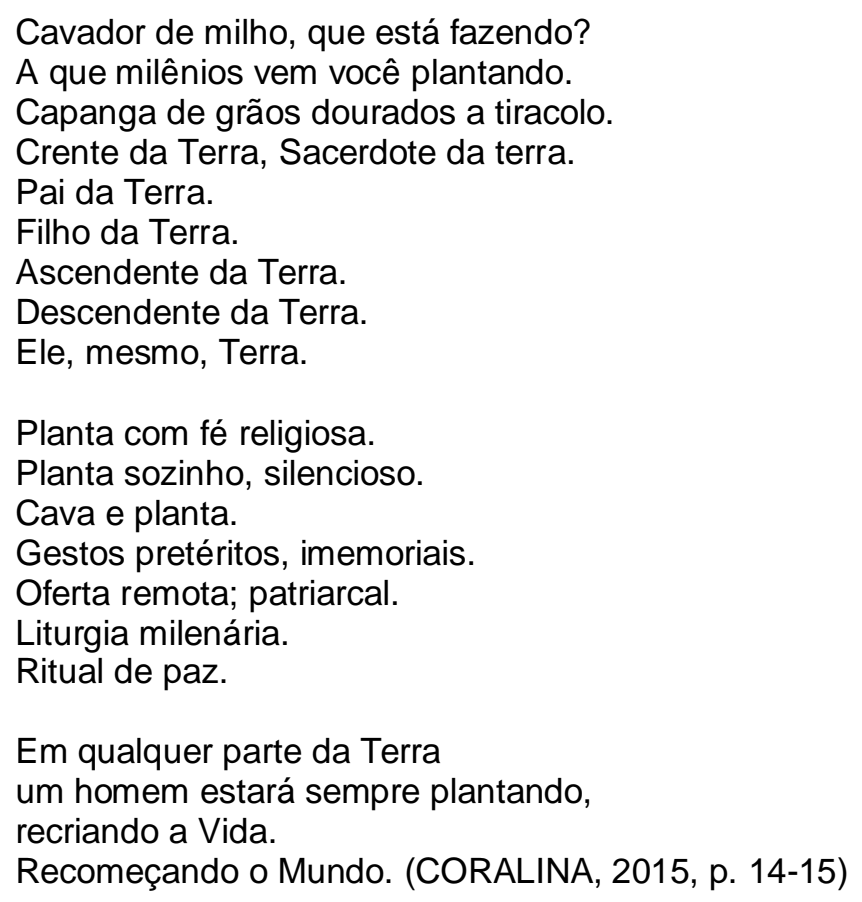

A criança do século XXI tem ao seu alcance uma infinidade de recursos proporcionados pela tecnologia digital à qual ela é apresentada cada vez mais cedo. Talvez por esse motivo sejamos levados a pensar que a temática filosófica contemplativa presente no "Poema do Milho" não pareça, num primeiro momento, condizente com as demandas do mercado editorial para crianças na contemporaneidade.

Destaca-se ainda que a última estrofe do trecho supracitado nos remete ao caráter universal da poesia de Cora Coralina, uma vez que ao associar a metáfora do plantio à recriação da vida e ao recomeço do mundo, a poeta aborda questões essencialmente humanas, que transcendem implicações geográficas, históricas e até de níveis de leitura, sendo compreensíveis mesmo ao leitor mais jovem. 
Todavia não se pode deixar de mencionar que, tomando por base a definição de Giorgio Agamben acerca do que é o contemporâneo, é exatamente o resgate de questões de outrora presente na obra coralineana o responsável por fazer dela plenamente contemporânea, pois há:

(...) uma singular relação com o próprio tempo, que adere a este e, ao mesmo tempo, dele toma distâncias; mais precisamente, essa é a relação com o tempo que a este adere através de uma dissociação e um anacronismo. Aqueles que coincidem muito plenamente com a época, que em todos os aspectos a esta aderem perfeitamente, não são contemporâneos porque, exatamente por isso, não conseguem vê-la, não podem manter fixo o olhar sobre ela. (AGAMBEN, 2009, p. 59)

Dessa forma, embora seja difícil conceber que ainda se recorra, no interior do país, à pura e simples observação do tempo, somada a técnicas ancestrais utilizadas ao longo da história da humanidade, é fundamental que a criança, em paralelo às toda tecnologia digital que Ihe é oferecida, tenha acesso a esse Brasil mais próximo da terra, do homem e, consequentemente, dela mesma.

\subsection{2 - O apendoar}

Cumprido o ritual de plantio do milho, nas estrofes que se seguem - a maior parte do poema -, o "eu" poético dedica-se ao ciclo de vida dessa planta comum, rude, sagrada. Desde o germinar, passando pelo pendão, pela flor, pela boneca e chegando à espiga, Cora Coralina proporciona ao leitor uma viagem por costumes, palavras, sotaques e circunstâncias de fé que, abordadas poeticamente, transcendem à simples institucionalização religiosa.

Neste momento evidencia-se o modo como o "eu" poético coralineano concebe tal viagem pelos mistérios da Natureza, valendo-se do uso meticuloso de descrições sinestésicas, que por sua vez são capazes de aguçar ainda mais a competência sensorial subjacente à percepção da criança em relação ao mundo.

Além de valer-se de uma construção poética abundante de sinestesias, Cora Coralina atribui ações ao milho, personificando-o, tornando-o protagonista de seu próprio brotar; e ele, numa constante batalha contra toda sorte de intempéries, como em uma grande aventura, luta pela vida.

Antes de avançar para a análise das estrofes, objetivando ilustrar os aspectos mencionados acima, convém acentuar que além da contemporaneidade do "Poema 
do Milho" defendida anteriormente, neste subtítulo, intenta-se advogar que Cora Coralina alça-o a uma dimensão atemporal, proporcionando ao seu leitor a consagração do instante poético, assim definido por Octavio Paz:

\begin{abstract}
O poema é mediação entre uma experiência original e um conjunto de atos e experiências posteriores, que só adquirem coerência e sentido e referência a essa primeira experiência que o poema consagra. $E$ isto é aplicável tanto ao poema épico como ao lírico e dramático. Em todos eles o tempo cronológico (...) sofre uma transformação decisiva: cessa de fluir, deixa de ser sucessão, instante que vem depois e antes de outros idênticos e se converte em começo de outra coisa. (...) Esse instante é ungido com uma luz especial: foi consagrado pela poesia, no melhor sentido da palavra consagração. Ao inverso do que ocorre com os axiomas dos matemáticos, as verdades dos físicos ou as ideias dos filósofos, o poema não abstrai a experiência: esse tempo está vivo, é um instante pleno de toda a sua particularidade irredutível e é perpetuamente suscetível de repetir-se em outro instante, de reengendrar-se e iluminar com sua luz novos instantes, novas experiências. (PAZ, 2006, p. 53)
\end{abstract}

Postas essas questões, inicia-se a análise observando que, a partir da estrofe abaixo, o "eu" poético atribui ao milho, uma vez plantado, características humanas. A presença da prosopopeia, exemplificada pelos verbos de ação - dormindo, realiza, vence e aponta - ao mesmo tempo que dá ao milho o status humanizador, permite que ele transcenda o caráter nutritivo puro e simples.

Dessa forma, caberá ao milho, diante de toda sorte de intempéries impostas pela natureza, lutar pela sua existência, contando, como se verá num segundo momento, com o auxílio do sagrado:

Milho plantado; dormindo no chão, aconchegados seis grãos na cova.

Quatro na regra, dois de quebra.

Vida inerte que a terra vai multiplicar

Evém a perseguição:

o bichinho anônimo que espia, pressente.

A formiga-cortadeira - quem-quem.

A ratinha do chão, exploradeira.

A rosca vigilante na rodilha,

O passo-preto vagabundo, galhofeiro, vaiando, sorrindo...

aos gritos arrancando, mal aponta.

O cupim clandestino

roendo, minando,

só de ruindade.

E o milho realiza o milagre genético de nascer.

Germina. Vence os inimigos.

Aponta aos milhares. (CORALINA, 2015, p. 16) 
O sagrado, sob o olhar do "eu" poético coralineano, adquire tamanha humanização capaz de tocar de modo sublime a percepção da criança, tornando-se um símbolo de libertação e não uma amarra dogmática.

A estrofe a seguir, é marcada inicialmente pela personificação do divino masculino - Jesus e São João - herança cultural cristã-católica. Mas é através da bênção em forma de chuva, simbolizada pelos cabelos brancos de uma chuva velhinha, dotada da capacidade criadora do feminino, que se pode ver a relação entre o sagrado e o milho carregada de uma ternura ancestral.

É o arquétipo funcionando como intermediário "entre os esquemas subjetivos e as imagens produzidas pelo ambiente perceptivo. Aqui se dá o ponto de articulação entre o imaginário e a razão." (SCOFANO; MAIA. 2018, p. 103):

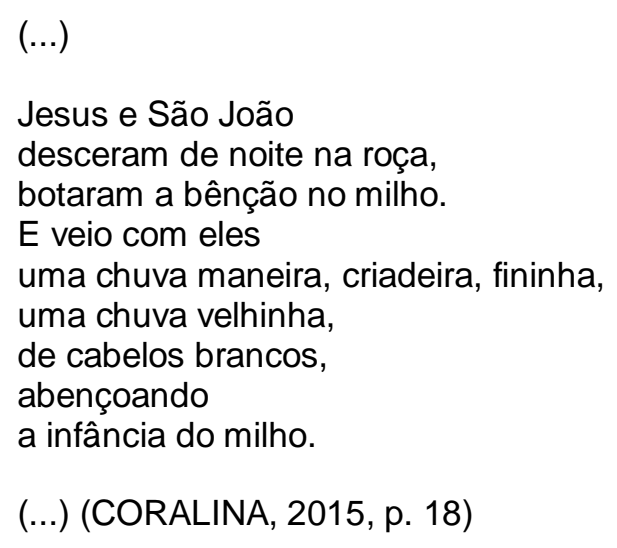

Além da bênção divina, as mãos humanas também se fazem necessárias na saga poética do milho. Contudo, a presença humana é minimizada pela apresentação onomatopeica e metonímica, obliterando a imagem do homem propriamente dita, o que, por outro lado, potencializa o protagonismo do milho em sua batalha contra as pragas:

As pragas todas, conluiadas.

Carrapicho. Amargoso. Picão.

Marianinha. Caruru-de-espinho.

Pé-de-galinha. Colchão.

Alcança, não alcança.

Competição.

Pac... Pac... Pac...

a enxada canta.

Bota o mato abaixo.

arrasta uma terrinha para o pé da planta.

"- Carpa bem feita vale por duas..."

quando pode. Quando não... sarobeia.

Chega terra. O milho avoa. 
Cresce na vista dos olhos.

Aumenta de dia. Pula de noite.

Verde. Entonado, disciplinado, sadio. (CORALINA, 2015, p. 19)

Embora passando muitas vezes despercebida pela crítica literária da época, Cora Coralina é contemporânea do Modernismo brasileiro, pois tece sua poesia valorizando circunstâncias do cotidiano, palavras de uso coloquial, questões regionais que aspiram ao universal.

Tais aspectos podem ser claramente percebidos na estrofe a seguir. Nela, compadres e vizinhos conversam despretensiosamente, numa conexão humana cada vez mais rara nas grandes metrópoles. As palavras utilizadas, carregadas de expressividade e de oralidade, remetem aos interiores do Brasil, mais especificamente ao interior de São Paulo, região significativa em sua biografia.

Outro ponto que dialoga profundamente com o universo da criança é a percepção intuitiva da gente da roça cujas analogias apresentam, segundo o "eu" poético, misteriosa coerência. É explícita a confluência linguística, cultural, religiosa que vai eclodir metaforicamente no fortalecimento do milho, ilustrado pela expressão de vislumbre do "eu" poético diante da roça, marcada pelo vocativo no último verso.

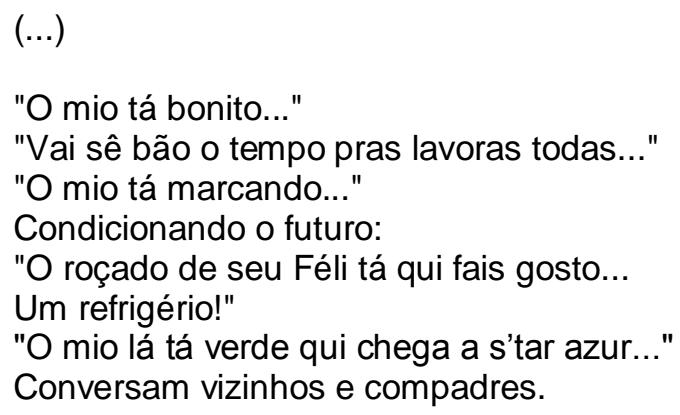


A última parte deste subitem abarca a fecundação do milho propriamente dita. Cora Coralina desenha metáforas que permitem ao leitor inúmeras analogias acerca do feminino e do masculino. O milho, fruto do amor e da harmonia vegetal, eclode como expressão máxima da beleza, da abundância e da pujança da vida.

Apesar da aparente complexidade do tema, aproxima-se do pensamento de Maria José Gordo Palo e Maria Rosa Duarte de Oliveira:

(...) o pensamento infantil está apto para responder à motivação do signo artístico, é uma literatura que se esteie sobre esse modo de ver a criança torna-a indivíduo com desejos e pensamentos próprios, agente de seu próprio aprendizado. A criança sob esse ponto de vista, não é nenhum ser dependente, nenhum "adulto em miniatura", mas é o que é, na especificidade de sua linguagem que privilegia o lado espontâneo, intuitivo, analógico e concreto da natureza humana." (PALO, OLIVEIRA, 1986, p.08)

Sendo assim, entende-se que a construção poética do "Poema do Milho", mesmo possuindo metáforas cujas analogias possam remeter a um processo de sedução entre o caráter feminino e masculino do milho - não há pretensão em abordar esse tema de modo mais profundo -, por redundar na geração e, portanto, na vida, é absolutamente inteligível pela criança. Seguem algumas estrofes para ilustrar esse pensamento:

Flor de milho, travessa e festiva.

Flor feminina, esvoaçante, faceira.

Flor masculina - lúbrica, desgraciosa.

$(\ldots)$

A boneca fecundada vira espiga.

Amortece a grande exaltação.

Já não importam as verdes cabeleiras rebeladas.

A espiga cheia salta da haste.

O pendão fálico vira ressecado, esmorecido,

no sagrado rito da fecundação. (CORALINA, 2015, p. 26-29)

Cora Coralina, ao construir poeticamente o sagrado rito da fecundação fazendo dele a expressão máxima da abundância da vida -, permite ao leitor experimentar a vivacidade imanente ao texto poético. Tal experiência é imprescindível na formação da criança, pois permitirá a ela conceber tanto o seu imaginário quanto compreender o mundo ao seu redor de forma mais humana. 
Assim, a autora leva o leitor para a colheita, apresentada pelo "eu" poético como o último, mas não menos importante, estágio do ciclo desse vegetal tão singular, que não deixa de ser generoso, abundante, substancial, necessário para a continuidade da vida. E é essa percepção de continuidade que será oferecida à criança, como se verá a seguir.

\subsection{3 - A colheita}

A partir da acepção da palavra "colheita" presente no Dicionário de Símbolos, pode-se compreender perfeitamente a simbologia da referida palavra, ainda hoje, a partir das metáforas bíblicas: "(...) colher-se-á o que se tiver semeado (Provérbios, 22, 8). A colheita como imagem do trabalho proposto (Mateus, 9, 37) etc." (CHEVALIER, GHEERBRANT, 2007, p. 264).

Interessante pensar que, assim como o Dicionário de Símbolos, o "eu" poético coralineano recorre igualmente ao sagrado, mais especificamente também aos preceitos bíblicos, para apresentar ao leitor as últimas estrofes do "Poema do Milho". Entretanto o traço poético de Cora Coralina evidencia uma colheita que transcende a ideia capital da subsistência pura e simples, ou seja, não se trata apenas de se colher o que se plantou, mas de se entender que, como tudo se volta para a terramãe, todos os que nela habitam têm direito ao seu quinhão.

Sob esse prisma, prevalecem os ideais de partilha, de solidariedade, de fraternidade, uma vez que todos os seres, filhos da mãe-terra, são unidos por um mistério cósmico ancestral, imemorial e por isso atemporal, que deve ser transmitido sempre e cada vez mais às nossas crianças, não como valor moral, mas, sobretudo, como valor ético, estético e humano.

Tons maduros de amarelo.

Tudo se volta para a terra-mãe.

O tronco seco é um suporte, agora,

onde o feijão verde trança, enrama, enflora.

Montes de milho novo, esquecidos, marcando claros no verde que domina a roça.

Bandeiras perdidas na fartura das colheitas.

Bandeiras largadas, restolhadas.

E os bandos de passo-pretos galhofeiros

gritam e cantam na respiga das palhadas.

"Não andeis a respigar" - diz o preceito bíblico. 
O grão que cai é o direito da terra.

A espiga perdida - pertence às aves

que têm seus ninhos e filhotes a cuidar.

Basta para ti, lavrador,

o monte alto e a tulha cheia.

Deixa a respiga para os que não plantam nem colhem.

- O pobrezinho que passa.

- Os bichos da terra e os pássaros do céu. (CORALINA, 2015, p. 29-30)

Tzvetan Todorov, em sua obra $A$ Literatura em perigo, ao falar da responsabilidade dos adultos diante da formação da criança no que tange à literatura, afirma: "A nós, adultos, nos cabe transmitir às novas gerações essa herança frágil, essas palavras que ajudam a viver melhor." (2010, p. 94)

Entende-se não ser necessário mencionar a importância do milho na constituição da cultura brasileira e mais, o quanto ele está intrinsecamente presente no imaginário coletivo do país, de modo muito especial por meio da memória gustativa. E Cora Coralina, como boa doceira que era, sabia disso. Bolos, doces, pamonhas, curais, entre tantas outras delícias que têm como ingrediente primordial esse cereal alimentaram e alimentam o Brasil desde os seus tempos mais remotos.

Talvez por isso ela tenha produzido um poema em que o milho, como "eu" poético, extrapole os limites de simples nutriente corpóreo, para metaforizar-se como alimento da alma e que, apesar de toda sua reconhecida importância históricocultural, adota uma postura de humildade - que deveria ser de todos.

Estrutura-se assim uma obra capaz de transcender as vicissitudes da contemporaneidade, oferecendo ao leitor uma oportunidade de se conectar poeticamente com o que há de mais profundo na concepção do país.

Por isso acredita-se que, no "Poema do Milho", Cora Coralina não apenas traça um retrato poético-identitário dos interiores do Brasil; ela nos ajuda o leitor a viver melhor, sobretudo mostrando artisticamente - por meio do ciclo da vida dessa planta comum, rude, que a todos alimenta - a vida no campo, a fé, os costumes, um jeito singular de olhar o mundo, ressaltando a beleza de se viver no simples ritmo da terra-mãe. 
$\mathrm{Na}$ introdução desta pesquisa, elencaram-se três fatores responsáveis pela presença da obra Os meninos verdes. São aspectos fundamentais e relevantes que merecem ser recapitulados.

O primeiro deles é o sucesso editorial desse conto, pois, embora escrito em 1968 e editado como livro apenas nos anos $1980^{16}$, mais precisamente em 1986 (um ano após a morte de Cora Coralina), conta, desde seu primeiro lançamento, com doze edições e sete reimpressões, sendo a última edição em 2007 e a última reimpressão em 2017.

O segundo diz respeito à estética coralineana, pois nessa obra, diferentemente de outras, privilegiou-se a prosa ao invés da poesia, evidenciando para o público a habilidade de Cora Coralina também em relação ao gênero narrativo por meio de um conto.

O terceiro trata da contemporaneidade da temática abordada na obra, voltada para questões que envolvem a relação entre o homem e a natureza, especialmente quando esta lhe oferece algo extraordinário.

Antes de prosseguir com a análise, é importante ressaltar as observações que constam na obra biográfica Cora Coralina: raízes de Aninha, escrita por Clóvis Carvalho Britto e Rita Elisa Seda. Nela, os autores abordam não apenas as circunstâncias sob as quais Cora Coralina escreveu o conto, como um breve comentário que será de extrema importância para se entender o cenário histórico dessa obra.

Salienta-se ainda que entre a primeira edição, cuja concepção visual e narrativa ficou a cargo dos cartunistas José Roberto Maia e Haroldo Gepp e realização do estúdio Gepp e Maia, e as edições subsequentes, concebidas por Claudia Scatamachia, houve uma substituição das ilustrações - que ficaram mais coladas ao texto - e um processo de adequação textual que mereceria um estudo à parte, mas basicamente busca atender mais a questões mercadológicas do que culturais e ou identitárias, por exemplo.

\footnotetext{
${ }^{16}$ Na década de 1980 havia o Programa Salas de Leitura do MEC/FAE e Os meninos verdes foi um dos selecionados e distribuídos para escolas públicas de todo o país.
} 
Postas tais questões, é importante ler os apontamentos do texto de Clóvis Carvalho Britto e Rita Elisa Seda:

\begin{abstract}
Cora escreveu "Os meninos verdes" em 1968: "'A história eu a rascunhei quando fui descansar no Araguaia. Eu peguei aqui em casa sete meninos verdes', informa Cora, com as mãos indicando uma medida aproximada de uns quinze centímetros, 'deste tamainho. Escrevi a história deles, que é real, autêntica, que ainda estou burilando, depois mando para o suplemento de O Popular publicar. É uma promessa formal que lhe faço. Os meninos verdes estão agora em Brasília, sob os cuidados de dona Scyla, mas quem os levou para lá foi dona Yolanda Costa e Silva, que os mandara buscar aqui. Dona Scyla vai mandar construir um local próprio, no jardim do Planalto" ${ }^{\prime 17}$. Os meninos verdes são filhos da terra e, como a Mãe Natureza, Cora se tornou mãe dos meninos, dos seres responsáveis pela perpetuação de uma mensagem de esperança e da crença de que o futuro será sempre melhor: "Posso adiantar que será uma estória maravilhosa de verde esperança no amanhecer do Novo Milênio, que vamos denominar 'Milênio da Paz Universal'. A Terra estará verde, renovada da força contagiante do trabalho e semeada até seus confins de Meninos Verdes. Serão eles mensageiros de bênçãos e aleluias, paióis acalculados, tulhas derramando na festa alegre das colheitas". ${ }^{18}$ (BRITTO; SEDA. 2009, p. 299)
\end{abstract}

Pode-se inferir, diante desse contexto, que a obra de Cora Coralina apresenta intrínseca relação com a natureza, já contemplada na supracitada em sua biografia $^{19}$, talvez inspirada pela infância na Fazenda Paraíso, tenha se dedicado de alguma forma, por onde passou, a questões ligadas à natureza: plantou árvores e flores em Jaboticabal e Penápolis, possuiu um sítio em Andradina e, voltando à Casa Velha da Ponte, cultivou junto ao pomar - para a feitura dos seus doces hortaliças e flores.

O conto é construído sob a égide da simplicidade estrutural e linguística, e é justamente por meio dessa singeleza no processo comunicacional que Cora Coralina toca seu leitor, talvez por aproximar-se daquela linguagem cúmplice que só as avós possuem. Ravel Giordano Paz, em seu artigo "D. Cora, a mucilagem e a herança das (outras) cores", abordou tais questões. Segundo ele:

\footnotetext{
${ }^{17}$ In RAMOS, Anatole. Cora Coralina: o tesouro da casa velha de Vila Boa, 1971.

${ }^{18}$ CORALINA, Cora. Os meninos Verdes / Cora Coralina; ilustrações de Gepp e Maia. - $1^{\underline{a}}$ ed. - São Paulo: Global, 1986, p. 15.

${ }^{19}$ Passou infância e adolescência na fazenda Paraíso, foi a sitiante de Andradina: etapas da sua vida relativas à gleba. Quando regressou a Goiás, Cora estreitou seu contato com a Grande Mãe Universal, recuperou o extenso quintal, tornando-o produtivo, cultivou hortaliças e árvores frutíferas, cuidou de suas rosas, com a ajuda de seu Vicente. Também manipulou as frutas, presentes da terra, transformando-as em doces. Além disso, estreitou o contato com os agricultores e sitiantes, os que vendiam frutas na Casa Velha da Ponte e os que comercializavam verduras no mercado da cidade. Teve amigos sitiantes e lavradores em Goiás. Utilizou sua pena e suas palavras para dignificar o trabalho. (BRITO, SEDA, 2009, p. 297)
} 
Em primeiro lugar, evidentemente, na qualidade do texto, de registro fortemente oralizado e uma fluidez que lhe conferem um sensível efeito de naturalidade e intimidade. E também, sem dúvida, no encanto simples, pouco original, mas por isso mesmo tão facilmente comunicável - um pouco como uma história nova que reconforta por já ser, de alguma forma, conhecida (...) (2006, p. 362)

Nesse contexto, pode-se dizer que, nOs meninos verdes, Cora Coralina oferece ao leitor, ainda que por meio de linguagem simples, uma experiência vegetal instigada pela inserção do insólito, que brota exatamente daquilo que a natureza pode proporcionar de mágico, de extraordinário, quando se permite, como a personagem Dona Cora, que ela brote.

Além da questão da linguagem e da forma, a opção pelo gênero textual conto permitiu a Cora Coralina criar uma história em que pessoas de seu convívio pudessem figurar também no universo ficcional da autora de uma maneira terna, sublime, leve, como só os contos podem propiciar, como afirmara André Jolles:

\begin{abstract}
As personagens e as aventuras do Conto não nos propiciam, pois, a impressão de serem verdadeiramente morais; mas é inegável que nos proporcionam certa satisfação. Por quê? Porque satisfazem, ao mesmo tempo, o nosso pendor para o maravilhoso e o nosso amor ao natural e ao verdadeiro mas, sobretudo, porque as coisas se passam nessas histórias como gostaríamos que acontecessem no universo, como deveriam acontecer. (JOLLES, 1976, p. 198).
\end{abstract}

Cora Coralina faz brotar, de uma desconhecida planta, criaturinhas verdes igualmente desconhecidas, sendo batizados pela narradora de "meninos verdes". Tornam-se frutos da junção entre a infância e a simbologia da cor verde, à medida que metaforizam a vida em sua plenitude, uma vez que o "verde é a cor do reino vegetal se reafirmando, graças às águas regeneradoras e lustrais nas quais o batismo tem todo seu significado simbólico. O verde é o despertar das águas primordiais, o verde é o despertar da vida." (CHEVALIER; GHEERBRANT, 2007, p. 939).

Além disso, a contextura poética da narrativa traz à tona, explicitamente, traços autobiográficos de uma das etapas mais importantes de sua vida: seu retorno à Casa Velha da Ponte; daí a relevância da presença de personagens que de fato fazem parte de sua vida, como seus netos, o empregado-amigo "seu Vicente", a 
vizinha "muito boa" que prontamente atendeu ao pedido de dona Cora de coser uma roupa para os meninos verdes.

Todos compõem um cenário que demonstra verossimilhança tamanha com a vida da autora, que justificaria o fato de a personagem Dona Cora enfatizar, já nas primeiras linhas, ter sido um "acontecido" e não mais uma estória qualquer. Tal afirmação, associada ao caráter secreto da informação, potencializa o tom de cumplicidade entre a avó e seus netinhos:

- E a estória dos Meninos Verdes, vovó?

- Então vocês querem saber a estória dos Meninos Verdes? Mas não é uma estória, é um acontecido. Me pediram para não divulgar o assunto, esperando para ver o que acontece, porque o caso é muito sério! Vou contar só pra vocês. (CORALINA, Cora, 2007, p. 03)

Interessante pensar que, se fosse possível conceber um paralelo entre $O$ Prato Azul-Pombinho e Os Meninos Verdes, não seria incorreto inferir o fechamento de um ciclo na vida da autora. Aquela que na primeira obra fora a bisneta de outrora, ouvindo atentamente a história da bisavó, tornara-se a avó contadora de histórias na segunda obra. Tal observação visa reassegurar a preocupação da autora no que diz respeito à formação do leitor e mais, à importância de se contar histórias.

Voltando ao "acontecido", outro aspecto importante de se abordar diz respeito à relação estabelecida entre o homem e a natureza, simbolizada não só pelos meninos verdes, mas também pela ligação com a terra representada tanto pelo quintal da Casa Velha da Ponte propriamente dito quanto pelo personagem de "seu Vicente", cujo "quintal é o mundo":

No quintal da Casa Velha da Ponte sempre tivemos horta com verduras, legumes. Também pomar com árvores de frutas variadas e jardim com flores.

O quintal é o mundo de seu Vicente, um homem que viveu sempre plantando, cultivando, colhendo. É prestadio e metediço. (CORALINA, Cora, 2007, p. 04)

Como se viu anteriormente, a cor verde simboliza "o despertar da vida", e a terra, entre tantas representações para vários povos ao redor do mundo, é a "origem de toda vida, (...) Grande Mãe" (CHEVALIER, GHEERBRANT, 2007, p. 879). Dessa forma, ao brotarem da terra, os meninos verdes metaforizam não apenas a presença do caráter maravilhoso na obra, mas, sobretudo, a própria vida. 
Além disso, outro aspecto considerado nesta tese, em relação à obra Os Meninos Verdes, diz respeito ao acolhimento, mais especificamente ao modo como a personagem "Dona Cora" lida com o surgimento dessas criaturinhas tão estranhas aos olhos de todos. A postura adotada por ela destoa do que se vê ao longo da história da literatura infantil, pois sempre prevaleceram temáticas de caráter moralizante, doutrinador, que objetivavam apenas a construção de valores, na maioria das vezes, visando atender às necessidades de uma sociedade comumente hostil às diferenças.

Entretanto, embora publicado pela primeira vez como obra infantil nos anos 1986, o texto de Cora Coralina dialoga profundamente com temáticas que se tornaram recorrentes a autores de literatura infantil e juvenil a partir dos anos 1990, motivados ora pela modernização do sistema legislativo em relação à formação de leitores, como, por exemplo, o surgimento da Lei de Diretrizes e Bases da Educação Nacional (LDB) - Lei n. 9394, de 20/12/1996 - ou dos Parâmetros Curriculares Nacionais (PCN's), ora pelas próprias demandas da sociedade contemporânea, desejosa de acolhimento e empatia, especialmente em relação às minorias, àqueles que, como os meninos verdes, não se deixam dividir em azul e rosa.

Abaixo, o trecho que exemplifica tal abordagem. Embora um pouco extenso, ajuda a perceber a preocupação da narradora-personagem Dona Cora em proporcionar àquelas criaturinhas, que mais tarde seriam "batizadas" de meninos verdes, o máximo de conforto, carinho e, por que não dizer, acolhimento:

\footnotetext{
(...)

Na primeira olhada não pude definir o que seria aquilo. Pareciam bichos, filhotes de passarinho, qualquer coisa que tivesse caído por ali, que tivesse despencado de um galho de árvore. E tinham se juntado na sombra daquelas duas plantas.

Depois me abaixei e examinei melhor. Eram seres vivos, com todas as formas de crianças em miniatura! Tomei um nas mãos, senti que era gelatinoso, com movimentos muito vivos, como querendo escapar da minha mão.

Assombrada, achei que precisava retirá-los da terra porque eles estavam bem sujinhos!

Seu Vicente apanhou o balaio que ele usa para os trabalhos no quintal. Forrou-o com panos e cobertas velhas e acomodou aqueles seres. Eram sete, e, achando que eles estavam com frio, seu Vicente rebuçou. Examinando de perto, perguntou:

- É bicho, é passarinho ou é gente?

- Velho, isso é uma coisa que nós vamos indagar, e não fale pra ninguém!

- É salta-caminho! - falou assombrado.

- Cubra com mais um cobertor e leve para o outro lado da casa. Depois do café vou resolver que se faz.
} 
Voltei para o fogão, fiz o café, e comecei a imaginar o que seria aquilo. Fui vê-los. Estavam juntinhos e já não tremiam.

Tomei um nas mãos e vi que tinha a cabeça verde, olhos verdes, boquinha verde, dentinhos verdes em ponta, orelhas verdes e o cabelinho como de milho, mas verde. Os pés e as mãos tinham unhas como garras de passarinho. Na barriguinha lisa, o umbigo era apenas uma manchinha verde mais escura.

Eram dois grupos. Um grupo tinha cabecinha chata e o cabelo pendendo para baixo. O outro grupo tinha cabeça pontuda, cabelo em ponta, tendendo para cima. Os sinais sexuais estavam um tanto indefinidos, mas notava-se a diferença entre um grupo e outro.

(...)

Aí, considerando que aquele mistério tinha que ser mantido em segredo, pensei que era muito pesado para mim só. Fiz um chamadinho para uma vizinha muito boa, que veio à minha casa. Contei a ela o acontecido.

(...)

- Dona Cora, vou fazer uns macacõezinhos de flanela, parece que eles estão com frio.

Costurou quatro macacões rosa e três azuis, achou que eram meninas e meninos. Eles aceitaram as roupas.

Mais tarde, quando voltamos lá, eles já tinham estraçalhado as flanelas com os dentinhos.

(...)

Dr. Passos veio mais tarde, olhou, espantou-se, e deu uma orientação muito inteligente:

- Tudo é verde neles. Como estão rejeitando alimento, vamos colorir a mucilagem de verde e vamos vesti-los de verde.

Minha vizinha costurou macacõezinhos verdes e passamos a alimentá-los com sopas e purês de espinafre, repolho, alface, agrião, chicória. Eles gostaram do verde das comidinhas e das roupas. (CORALINA, 2007, p. 07, $08,09,10,14)$

Outra inferência que se considera relevante reside na sutileza do discurso, proporcionada não apenas pela simplicidade da forma e da linguagem, mas, sobretudo, pela leveza e naturalidade explicitada pelo modo carinhoso, atencioso, como a narradora-personagem trata os meninos verdes e instiga os que estão a sua volta a fazerem o mesmo.

Crianças têm uma predisposição quase natural a receber o extraordinário. Ainda que intuitivamente, lidam com ele de modo visceral, nada lhes escapa à percepção; talvez por isso quando brincam, conversam sozinhas, interpretam sons, falas. Nesse momento, imaginário e realidade se confundem e o maravilhoso tornase natural, possível, exequível.

Cora Coralina, por meio do jeito de agir de Dona Cora, proporciona ao leitor a possibilidade de olhar para o extraordinário com humanidade, no sentido mais sublime da palavra. Acolher os meninos verdes, cuidar deles, alimentá-los, protegêlos, metaforiza tudo aquilo que se deveria fazer quando se tem a oportunidade de 
entrar em contato com o fantástico. Tal mensagem é desenhada com tamanha simplicidade que o leitor a recebe naturalmente.

A história caminha para o seu desfecho quando Dona Cora, em busca de proteção para os meninos verdes, pede ajuda à Primeira-Dama do país que, segundo sua boa vizinha, era "uma criatura muito humana". Todavia o olhar acolhedor de Dona Cora não fora transferido para os outros personagens e, embora devidamente cuidados, o tratamento dispensado aos meninos verdes assemelha-se muito ao modo como as pessoas se comportam diante do insólito na contemporaneidade: preocupa-se mais em desnudá-lo e ou explorá-lo do que em apreciar a beleza e ou o caráter extraordinário do que é apresentado.

\footnotetext{
Quando chegaram ao Palácio, foi um espanto geral. O presidente mandara construir, na parte do Palácio reservada à família, uma casa especial com auditores e visores. Quando não estava ocupado, gostava de sentar-se na frente da casa dos Meninos Verdes.

Uma enfermeira os acompanhava permanentemente. A alimentação estava a cargo da nutricionista. Pedagogos, psicólogos e antropólogos faziam parte da equipe de estudos. Os serezinhos cresciam devagar.

(...)

Foi quando resolveram criar a Cidade dos Meninos Verdes, um polo de turismo que seria mais interessante que a Disneylândia, na América do Norte. Chamaram um grande arquiteto para projetar a cidade.

Quando estava para iniciar-se a construção da cidade, cientistas brasileiros convidaram cientistas estrangeiros para conhecer aqueles seres que surpreendiam a todos pelo seu desenvolvimento.

Vieram cientistas de muitos países, e ficaram assombrados, sem saber o que eram e de onde tinham vindo aqueles serezinhos. Examinaram, fotografaram, radiografaram, observaram, indagaram. (CORALINA, 2007, p. $20,21)$
}

Sabe-se que "(...) a literatura para crianças, hoje, guarda características primordiais da arte, ou seja, olhar a sociedade e devolver a ela uma matéria passível de discussão e mudança.” (GREGORIN FILHO, 2009, p. 41). Sob esse prisma, embora a própria Cora Coralina declare ter concebido os meninos verdes como símbolos de vida e esperança, o desfecho que é dado a essas criaturinhas misteriosas e, por isso, fantásticas, diz muito acerca de como a sociedade contemporânea trata aquilo que não compreende.

A Literatura infantil e juvenil na contemporaneidade, diferentemente de outrora, não se deixa mais enredar pelas amarras impostas pela sociedade. Ao contrário, ela brinca com essa ânsia pela compreensão científica, essa necessidade de explicações exatas, o desejo quase doentio de buscar racionalidade e lucidez em 
tudo que se mostra fora dos padrões estabelecidos, como direta ou indiretamente a Arte o faz, uma vez que é livre, na acepção mais profunda da palavra.

Sob tal aspecto, Cora Coralina concebe os meninos verdes, que curiosamente são sete. $\mathrm{E}$, neste ponto, ressaltar a riqueza simbólica que envolve além desse, os números três e quatro, que nos remetem aos dois grupos divididos inicialmente - os três de cabeça chata e cabelo pendendo para baixo e os quatro de cabeça pontuda e cabelo em ponta - torna-se fulcral para a conclusão da análise.

Assim, uma vez mais, o Dicionário de Símbolos, pode captar, o mais amplamente possível, a profundidade e a profusão poética presentes no conto coralineano, pois associando "o número quatro, que simboliza a terra (com seus quatro pontos cardeais) e o número três, que simboliza o céu, o sete representa a totalidade do universo em movimento." (CHEVALIER; GHEERBRANT, 2007, p. 826).

Assim se pode inferir que, na obra Os Meninos Verdes, Cora Coralina apresenta ao leitor, por meio de uma breve narrativa, pouco original na forma e direta na linguagem, tamanha singeleza comparada apenas ao olhar que a narradora Dona Cora dispensou aos meninos verdes que, como ela mesma dissera, Ihe foram confiados.

E é esse olhar solícito, acolhedor e amoroso, o que cintila, ainda que intuitivamente, na criança, permitindo-lhe, como aos meninos verdes, que vão "(...) crescendo devagarinho (...)", dando "sinais inteligência e vivacidade" (CORALINA, 2007 , p. 22), necessitando fundamentalmente, entretanto, de um país que, como na história, rejeite propostas outras, reconhecendo-os como seus.

Diante desse cenário, vale conhecer a proposição de Tzvetan Todorov. Segundo ele:

\footnotetext{
Como a filosofia e as ciências humanas, a literatura é pensamento e conhecimento do mundo psíquico e social em que vivemos. A realidade que a literatura aspira compreender é, simplesmente (mas, ao mesmo tempo, nada é assim tão complexo), a experiência humana. Nesse sentido, pode-se dizer que Dante ou Cervantes nos ensinam tanto sobre a condição humana quanto os maiores sociólogos e psicólogos e que não há incompatibilidade entre o primeiro saber e o segundo. (TODOROV, 2010, p. 77)
}

Não se pode subestimar a percepção ou ainda a capacidade de compreensão que a criança tem do mundo ao seu redor. E a literatura infantil e juvenil produzida nas últimas décadas tem mostrado exatamente que ela - a criança - é perfeitamente capaz de apreender - estética, sinestésica, poeticamente - as 
mensagens emitidas explícita ou implicitamente pelo texto literário. Que a criança é, inclusive, mais predisposta que o adulto, talvez por ter seu raciocínio analógico mais apurado, visto que ainda livre de parte significativa das sistematizações linguísticas, contando mais com a intuição e com a sensibilidade do que com a lógica e com a objetividade.

É sabido que Cora Coralina colheu os louros de sua literatura já no "tarde da vida", como ela mesma escrevera no poema "Ressalva" (p. 27) de seu primeiro livro: Poemas dos becos de Goiás e estórias mais. Sabe-se também que ainda há muitas reticências na academia em relação ao seu nome e que, por várias circunstâncias sociais que não caberiam nesta pesquisa, a notoriedade de sua literatura se deveu, do ponto de vista do mercado editorial, a uma espécie de "homologação" vinda da sensibilidade do olhar de Carlos Drummond de Andrade - poeta já estabelecido, de valor reconhecido.

Entretanto encerra-se este capítulo salientando-se a relevância de sua obra não só na academia, mas, sobretudo, na sociedade - para auxiliar na compreensão cultural, histórica, identitária, social e poética desse interior do Brasil que reside não só na Casa Velha da Ponte ou na Fazenda Paraíso, ou mesmo em Goiás, ou ainda os interiores de São Paulo, mas em cada um dos brasileiros. Cora Coralina, como Dante ou Cervantes, têm muito a ensinar, desde a mais tenra idade, sobre a condição humana. 
Figura 2: A escrivaninha de Manoel de Barros

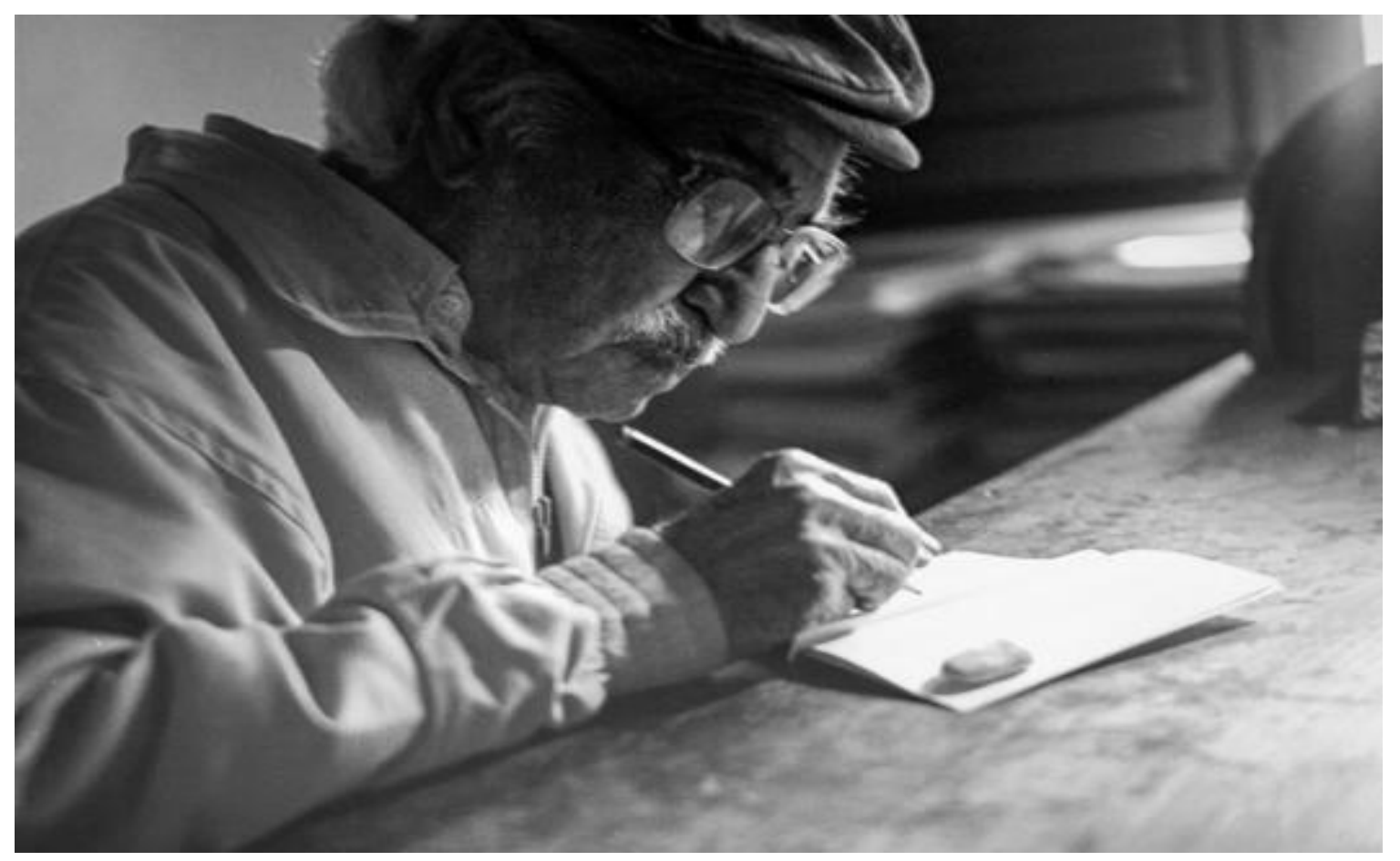

Fonte: https://www.nexojornal.com.br/expresso/2016/12/19/Como-e-por-que-ler-Manoel-deBarros-o-poeta-das-miudezas, acesso no dia 18/11/2019. 


\section{CAPÍTULO II: MANOEL DE BARROS: ENTRE O QUINTAL E OS POEMAS}

Acho que o quintal onde a gente brincou é maior do que
a cidade. A gente só descobre isso depois de grande. A
gente descobre que o tamanho das coisas há que ser
medido pela intimidade que temos com as coisas. Há de
ser como acontece com o amor. (...) Sou hoje um
caçador de achadouros da infância. Vou meio
dementado e enxada às costas cavar no meu quintal
vestígios dos meninos que fomos. (...)

Manoel de Barros in "Achadouros". Memórias Inventadas: As Infâncias de Manoel de Barros, 2008, p. 59

Manoel Wenceslau Leite de Barros, popularmente conhecido como Manoel de Barros, nascera em Cuiabá, Mato Grosso, em 16 de dezembro de 1916, segundo filho de João Leite de Barros e Alice Pompeu Leite de Barros. Após dois meses, a família fixa residência em Corumbá e depois numa fazenda na Nhecolândia, no Pantanal mato-grossense. Até os 17 anos viveu entre a casa da família e um internato.

Foi para o Rio de Janeiro, onde ficou até se formar bacharel em Direito, em 1941. Viveu em Nova Iorque, viajando também pela América do Sul (Bolívia e Peru) e pela Europa (Itália, França e Portugal). Retornou ao Pantanal mato-grossense em 1959 para assumir uma fazenda de gado que recebera de herança, passando a dividir seu tempo entre o Rio de Janeiro e o Pantanal.

Nessa época, embora sua poesia já começasse a tomar corpo, ainda estava afastado dos círculos literários. Faleceu em Campo Grande em 13 de novembro de 2014. Pode-se associá-lo à terceira geração do modernismo brasileiro, uma vez que a essência de sua confecção poética reside no trabalho com a linguagem. É considerado inovador para a época e característica inerente da geração que também inclui João Guimarães Rosa, João Cabral de Melo Neto e Clarice Lispector.

Dessa forma, não seria incorreto dizer que os poemas de Manoel de Barros concebem uma estética capaz de proporcionar ao leitor percepções que vão desde a criativa experimentação estrutural das palavras - quase subversiva - no melhor dos sentidos, até o contato com as raízes mais profundas da palavra.

Ao indagar qual seria a fonte da poesia, Edgar Morin, em sua obra Amor, Poesia, Sabedoria reconhece a complexidade de se responder a tal pergunta, uma vez que ela - a fonte - "se perde nas profundezas humanas tanto quanto nas 
profundezas da pré-história, onde surgiu a linguagem, nas profundezas dessa embalagem estranha que é o cérebro e o espírito humano" (2008, p. 35). Todavia, mesmo com tamanha complexidade, os leitores nunca cessam de buscá-la, desejosos de provar sua água lustral.

É preciso reconhecer, como Morin, que independentemente da cultura, “(...) o ser humano produz duas linguagens a partir de sua língua: uma, racional, empírica, prática, técnica; outra, simbólica, mítica, mágica." (2008, p. 35), ambas podem ou não se entrelaçar, se misturar ou ainda se repelir, contudo possuem especificidades muito claras:

\begin{abstract}
A primeira tende a precisar, denotar, definir, apoia-se sobre a lógica e ensaia objetivar o que ela mesma expressa. A segunda utiliza mais a conotação, a analogia, a metáfora, ou seja, esse halo de significações que circunda cada palavra, cada enunciado e que ensaia traduzir a verdade da subjetividade. Essas duas linguagens podem ser justapostas ou misturadas, podem ser separadas, opostas, e a cada uma delas correspondem dois estados. O primeiro, chamado de prosaico, no qual nos esforçamos por perceber, raciocinar, e que é o estado que cobre uma grande parte de nossa vida cotidiana. $O$ segundo estado, que se pode justamente chamar de "estado segundo", é o estado poético.

O estado poético pode ser produzido pela dança, pelo canto, pelas cerimônias e, evidentemente, pelo poema. Fernando Pessoa dizia que, em cada um de nós, há dois seres. O primeiro, o verdadeiro, é o dos nossos sonhos, que nasce na infância e que continua pela vida toda. $O$ segundo ser, o falso, é o das aparências, de nossos discursos, atos, gestos. Não diria que um é verdadeiro e o outro, falso, mas, efetivamente, a cada um desses dois estados correspondem dois seres em nós. A esse estado segundo corresponde 0 que 0 adolescente Rimbaud percebeu muito claramente, principalmente em sua Carta do vidente: esse estado não é um estado de visão, mas um estado de vidência. (MORIN, 2008, p. 35, 36)
\end{abstract}

A teoria concebida por Morin dialoga profundamente com o que se defende nesta tese, ou seja, que a essência da poesia de Manoel de Barros pretende proporcionar ao leitor viver constantemente em estado poético, mergulhado na infância da palavra ${ }^{20}$. Ao longo dos subtítulos, será demonstrado que tanto a estética quanto a temática textual do poeta mato-grossense relaciona-se intimamente com o universo analógico, intuitivo, metafórico, sensível, sinestésico da criança.

Em linhas gerais, a estética da poesia de Manoel de Barros possui uma estrutura em que as funções metalinguística e poética de Jakobson oscilam harmonicamente buscando extrair a máxima potência do signo verbal, subvertendo

${ }^{20}$ BARROS, Manoel de. Menino do mato. São Paulo: Leya, 2010, p. 33. 
muitas vezes seu sentido racional, objetivo, prosaico, em poemas formados às vezes por um único verso.

No que concerne à temática, a poesia de Manoel de Barros se debruça sobre as reminiscências da infância; a relação de comunhão entre a criança e a natureza; a palavra em seu estado bruto, vegetal.

Além disso, ao contrário de certa grandiloquência presente na poesia brasileira de um modo geral, mesmo quando poetas como Manuel Bandeira ou Carlos Drummond de Andrade abordam temas cotidianos, as imagens que brotam das metáforas elaboradas por Manuel de Barros aguçam a percepção e o olhar do leitor para as miudezas.

Importam para a poesia de Manoel de Barros as grandezas do ínfimo ${ }^{21}$. Sob esse aspecto, passarinhos, formigas, sapos, pedras, gravetos, riachos, tudo é material para seu organismo poético, e mais, os traços metafóricos compostos estão sempre em comunhão com a infância, divertindo-se com a criança que reside no leitor. É como se, enquanto Drummond nos apresenta a pedra no meio do caminho, Manoel nos convida a colocá-la no estilingue e atirá-la no riacho.

O trecho a seguir, extraído do texto "Manoel por Manoel", exemplifica o que se disse até então:

\begin{abstract}
(...)
Porque se a gente fala a partir de ser criança, a gente faz comunhão: de um orvalho e sua aranha, de uma tarde e suas garças, de um pássaro e sua árvore. Então eu trago das minhas raízes crianceiras a visão comungante e oblíqua das coisas. Eu sei dizer sem pudor que o escuro me ilumina. É um paradoxo que ajuda a poesia e que eu falo sem pudor. Eu tenho que essa visão oblíqua vem de eu ter sido criança em algum lugar perdido onde havia transfusão da natureza e comunhão com ela. Era o menino e os bichinhos. Era o menino e o sol. O menino e o rio. Era o menino e as árvores. (BARROS, 2008, p. 11)
\end{abstract}

Tendo em mente tais questões, este capítulo será desdobrado em três partes, lembrando ainda que, como já foram elucidados os critérios de escolha das obras na Introdução, será traçada rapidamente uma breve descrição dos subcapítulos com o intuito de fornecer ao leitor uma visão panorâmica do desenho do capítulo.

Na primeira parte - O quintal-mundo do Menino do mato - haverá reflexão sobre o caráter universal da poesia de Manoel de Barros, defendendo a existência

\footnotetext{
${ }^{21}$ BARROS, Manoel de. Livro sobre Nada. Rio de Janeiro: Record, 1998, p. 13.
} 
de um movimento simultaneamente centrífugo e centrípeto, tornando-a atemporal e universal, permitindo a todos serem meninos do mato no quintal-mundo do poeta.

A segunda parte - Fantasia em prosa e poesia nas Memórias inventadas: As infâncias de Manoel de Barros - abarca a construção poético-metafórica do fantástico na infância, independentemente do gênero.

Na terceira parte - Palavra-brinquedo: infância poética entre as Ignorãças e o Nada - abordar-se-á a presença do caráter lúdico na poesia de Manoel de Barros e o modo como tal característica pode ajudar o leitor a resgatar e ou construir no seu imaginário o estado poético da infância.

Para que o processo de análise supracitado seja bem sucedido, será empregado, entre outros, entre outros, o método de estudo da poesia e da literatura considerado adequado por Ezra Pound, o qual, a nosso ver, encaixa-se perfeitamente ao estilo de Manoel de Barros. Segundo ele: "O MÉTODO adequado para o estudo da poesia e da literatura é o método dos biologistas contemporâneos, a saber, exame cuidadoso e direto da matéria e contínua COMPARAÇÃO de uma "lâmina" ou espécime com outra." (POUND, 2006, p. 23).

Sob essa perspectiva, defende-se que é possível, na construção poética do escritor mato-grossense, o emprego das três modalidades concebidas por Ezra Pound: fanopeia, melopeia e logopeia; o que denotaria a riqueza e a sofisticação literária de Manoel de Barros.

Ao final deste capítulo, pretende-se demonstrar que a literatura de Manoel de Barros proporciona ao leitor, por meio do modo como ele tece questões da infância, uma experiência poética no sentido mais visceral, definido da seguinte forma por Octavio Paz:

\footnotetext{
"A experiência poética é uma revelação da nossa condição original. E essa revelação sempre desemboca numa criação: a de nós mesmos. A revelação não descobre algo externo, que estava ali, alheio: o ato de descobrir implica a criação do que vai ser descoberto, o nosso próprio ser. E nesse sentido pode-se dizer, sem temor de cair em contradição, que o poeta cria o ser." (PAZ, 2012, p. 161)
}

Dessa forma, defende-se, neste segundo capítulo da pesquisa, que o ser criado pela literatura de Manoel de Barros é a criança-em-comunhão-com-a-terra, no sentido mais visceral, biológico e harmônico do termo, encerrada no imaginário do leitor adulto e tão familiar ao leitor criança. 


\section{1 - O quintal-mundo do Menino do mato}

Todos têm uma relação ancestral e inexplicável com a natureza. Seja pela ascendência indígena que reside em cada um, seja pela mãe natureza que, a despeito de todo tipo de usurpação sofrida, ainda na contemporaneidade insiste em prover este país de belezas naturais, mananciais límpidos, cachoeiras cristalinas, animais exóticos, cavernas misteriosas, árvores majestosas, frutas suculentas, mesmo nos grandes centros urbanos do país, é possível, sem muito esforço, ter acesso à pujança da natureza.

$\mathrm{Na}$ história da literatura brasileira, raros são os poetas cuja abordagem poética contempla de modo tão visceral a comunhão existente entre a criança e a natureza. Manoel de Barros é um deles. Talvez por isso, Menino do Mato tenha figurado no Programa Nacional da Biblioteca Brasileira (PNBE) ${ }^{22}$ já na segunda década do século XXI $(2013)^{23}$, sendo distribuído para escolas de todo o país, permitindo a crianças que vivem sob contextos sociais tão díspares o acesso à obra.

Acredita-se que esse reconhecimento se deve não só à abrangência da abordagem poética, como se mencionou no parágrafo anterior, mas também à construção textual de Manoel de Barros, que, logo na epígrafe da obra, sinaliza o caminho que, segundo ele, deveria ser seguido pelo homem. A frase de Sören Kierkegaard é explícita, não deixando margem para ambiguidades: "O homem seria metafisicamente grande se a criança fosse seu mestre." ${ }^{24}$.

Já se mencionou nesta tese que a criança tende a responder majoritariamente pela intuição. Seu imaginário é alimentado por questões muito mais ligadas à emoção do que à razão, portanto, oferecer a ela um livro que, já no primeiro poema, Ihe possibilita brincar com as palavras, parece ser a forma mais eficaz de tocá-la, visto que a "(...) fantasia e o devaneio são a imaginação movida pelos afetos." (BOSI, 1977, p. 65).

Postas tais questões, será iniciada uma abordagem, considerando Menino do Mato, primeiramente, do ponto de vista de sua estrutura. Trata-se de uma obra dividida em duas partes, a saber: Menino do Mato e Caderno de aprendiz. Os seis

\footnotetext{
22 Programa Nacional Biblioteca da Escola (PNBE): é executado pelo Fundo Nacional de Desenvolvimento da Educação (FNDE) em parceria com a Secretaria de Educação Básica do Ministério da Educação.

${ }^{23}$ Informação extraída do site www.portal.mec.gov.br, acesso em 15/10/2019.

${ }^{24}$ Epígrafe da Primeira Parte da obra Menino do Mato.
} 
poemas que compõem a primeira parte aludem, primordialmente, a um processo de aprendizagem humana que consiste em desver o mundo ${ }^{25}$, pois, segundo o poeta, só se pode conceber o imaginário infantil assim.

Em segundo lugar, do ponto de vista da temática, a premissa apontada por Manoel de Barros na primeira parte da obra se relaciona com o modo como se defende que a Arte e, mais especificamente, a literatura, para que cause as sensações propostas pela construção verbal do "eu" poético, deve ser oferecida para a criança...

(...) como arte e prazer, arte porque é o resultado de um fazer estético do(s) autor(es) e prazer porque o contato com a arte pode ser encarado desde a mais tenra idade como uma experiência ricamente prazerosa, capaz de nos envolver e trazer novas dimensões ao cotidiano. (GREGORIN FILHO, 2009, p. 63)

Nesse aspecto, defende-se que na poesia de Manoel de Barros, a estética do poema privilegia metáforas que pretendem remeter o leitor a uma espécie de linguagem "pré-concebida", ou melhor, de um novo meio de utilizá-la, dotado de um tom de cumplicidade, de brincadeira, convidativo para a criança, e por esse motivo capaz de proporcionar uma nova perspectiva sobre a palavra e, consequentemente, uma nova dimensão ao cotidiano, uma possibilidade de estado poético.

Com o intuito de ilustrar essas observações, apresenta-se, por meio do poema abaixo, o jeito cúmplice com o qual o "eu" poético se dirige ao leitor, revelando-lhe as brincadeiras com as palavras que aconteciam em sua casa e the apresentando Bernardo ${ }^{26}$. Assim já não se trata mais de uma relação dupla, mas tripla.

Nela, o "eu" poético envolve o leitor em seu mundo, como crianças que se unem intimamente um minuto depois de se conhecerem. Tal atitude plena de confiança e afeto, embora considerada ingênua pelos adultos, é comum no universo infantil.

Eu queria usar palavras de ave para escrever.

Onde a gente morava era um lugar imensamente e sem nomeação.

Ali a gente brincava de brincar com palavras tipo assim: Hoje eu vi uma formiga ajoelhada na pedra!

\footnotetext{
${ }^{25}$ BARROS, Manoel de. Menino do mato. São Paulo: Leya, 2010, p. 09.

${ }^{26}$ Personagem recorrente na literatura de Manoel de Barros.
} 


\begin{abstract}
A Mãe que ouvira a brincadeira falou:
Já vem você com suas visões!

Porque formigas nem têm joelhos ajoelháveis

e nem há pedras de sacristias por aqui.

Isso é traquinagem da sua imaginação.

O menino tinha no olhar um silêncio de chão

e na sua voz uma candura de Fontes.

O Pai achava que a gente queria desver o mundo para encontrar nas palavras novas coisas de ver assim: eu via a manhã pousada sobre as margens do rio do mesmo modo que uma garça aberta na solidão de uma pedra.

Eram novidades que os meninos criavam com as suas palavras.
\end{abstract}

Assim Bernardo emendou nova criação: Eu hoje vi um sapo com olhar de árvore.

Então era preciso desver o mundo para sair daquele lugar imensamente e sem lado.

A gente queria encontrar imagens de aves abençoadas pela inocência.

O que a gente aprendia naquele lugar era só ignorâncias para a gente bem entender a voz das águas e dos caracóis.

A gente gostava das palavras quando elas perturbavam o sentido normal das ideias.

Porque a gente também sabia que só os absurdos enriquecem a poesia. (BARROS, 2010, p. 9-10)

O "eu" poético de Manoel de Barros, brincando de brincar com palavras, apresenta ao leitor traços fundamentais de sua estética poética, que propõe desver o mundo, uma vez que só os absurdos enriquecem a poesia.

Essa dança de metáforas paradoxais subvertendo, perturbando o sentido normal das ideias, quase desprezando a razão, diz muito a imaginação da criança, principalmente sob uma perspectiva bachelardiana que, nas palavras de Reuber Gerbassi Scofano,

(...) valoriza extremamente a imagem como algo independente e que se autoproduz. Não leva em conta nenhuma forma de causalidade que dê explicações para a imagem poética. Propõe uma fenomenologia com seu aspecto próprio. Uma fenomenologia da imaginação, que se estabelece diretamente pelo encontro direto com a imagem. Trata-se de pura presença, pois se revela no instante. Não explica nem tenta entender o objeto e apenas usufrui do encontro por meio da recuperação de uma ingenuidade e simplicidade perdidas que são a sabedoria de ver as coisas no frescor de sua primeira vez. É a experiência da adesão total a imagem como epifania. Não precisa do saber. (SCOFANO, 2018, p. 90, 91)

Seguindo essa linha de pensamento, entende-se que o desver do mundo pressupõe uma desconstrução da visão preestabelecida do leitor, geralmente objetiva, racional, compelida de toda gama de sistematizações linguísticas. 
Sob esse aspecto, destacam-se simultaneamente o caráter centrípeto e o centrífugo da obra, ilustrados pela proposta do "eu" poético, permitindo que o leitor, num primeiro momento, mergulhe na inocência da palavra, para convidá-lo, nos versos que se seguem, a fazer ecoar poesia por meio da subversão do sentido original, objetivo da palavra - afinal, essa é a brincadeira.

A problematização que reside na temática do poema acima dá o tom de toda a obra, pois o "eu" poético, ao subverter o sentido lógico, objetivo, prosaico das palavras - A gente gostava das palavras quando elas perturbavam / o sentido normal das ideias - metaforiza uma ação aparentemente apreendida com naturalidade no universo concebido pelas crianças que gozam da liberdade de fazer das palavras o seu brinquedo.

Tal característica pode ser ilustrada também no poema a seguir. O "eu" poético de Manoel de Barros quer brincar com as palavras, ou melhor, valer-se do uso delas para fazer traquinagem da imaginação do leitor. Sob esse aspecto, está determinado a não ocupar o tempo usando palavras bichadas de costumes, contrariando o conselho de Paul Valéry.

O crítico, em sua obra Variedades, ao discorrer sobre "Poesia e Pensamento Abstrato", aponta a necessidade de se tomar "(...) cuidado com as primeiras palavras que pronunciam uma questão em nosso espírito." (1999, p. 202), mesmo reconhecendo em seguida que uma “(...) questão nova está, primeiramente, no estado de infância em nós, ela balbucia.” (1999, p. 202). É justamento esse estado de infância presente não só nas palavras, mas no próprio homem que a estética de Manoel de Barros parece desejar. Eis o poema:

IV

Lugar mais bonito de um passarinho ficar é a palavra.

Nas minhas palavras ainda vivíamos meninos do mato, um tonto e mim.

Eu vivia embaraçado nos meus escombros verbais. O menino caminhava incluso em passarinhos.

E uma árvore progredia em ser Bernardo.

Ali até santos davam flor nas pedras.

Porque todos estávamos abrigados pelas palavras.

Usávamos todos uma linguagem de primavera.

Eu viajava com as palavras ao modo de um dicionário.

A gente bem quisera escutar o silêncio do orvalho sobre as pedras.

Tu bem quisera também saber o que os passarinhos sabem sobre os ventos.

A gente só gostava de usar palavras de aves porque eram palavras abençoadas pela inocência.

Bernardo disse que ouvira um vento quase encostado 
nas vestes da tarde.

Eu sonhava de escrever um livro com a mesma

inocência com que as crianças fabricam seus navios

de papel.

Eu queria pegar com as mãos no corpo da manhã.

Porque eu achava que a visão fosse um ato poético

do ver.

Tu não gostasse do caminho comum das palavras.

Antes melhor eu gostasse dos absurdos.

E se eu fosse um caracol, uma árvore, uma pedra?

E seu eu fosse?

Eu não queria ocupar o meu tempo usando palavras bichadas de costumes.

Eu queria mesmo desver o mundo. Tipo assim: eu vi um urubu dejetar nas vestes da manhã.

Isso não seria de expulsar o tédio?

E como eu poderia saber que o sonho do silêncio era ser pedra! (BARROS, 2010, p. 15-16)

Edgar Morin, em sua obra Amor, Poesia, Sabedoria, cita a seguinte afirmação de Hölderlin: "O homem habita a terra poeticamente." $(2008$, p. 36) para ilustrar a importância do texto poético na concepção do homem. Defende-se, sob esse aspecto, que a poesia de Manoel de Barros transcende o caráter regional e temporal, e vai para o universal e atemporal, por proporcionar ao leitor a experiência da concretude da palavra poética: Lugar mais bonito de um passarinho ficar é a palavra.

Ou seja, é na concretude da palavra que reside a beleza do mundo e quando "oferecemos um poema para a criança ler, é importante fazê-la tomar contato com a concretude da palavra poética, isto é, primeiro observa-se o trabalho com a palavra, sua sonoridade, seu ritmo e toda musicalidade que o poema pode proporcionar." (GREGORIN FILHO, 2009, p. 75).

Nesse sentido, considera-se a poesia de Manoel de Barros fundamental para a criança, por proporcionar a ela tanto um aguçamento de sua percepção estética, por meio da brincadeira com a palavra, quanto uma (re)ligação poética com a infância das palavras e, consequentemente, com a infância dela mesma. Acredita-se ainda que esse processo deve ir além do ambiente escolar e acompanhá-la por toda a vida.

O poema abaixo encerra a análise da primeira parte da obra Menino do Mato. Objetiva-se com ele ilustrar uma vez mais a universalidade da obra de Manoel de Barros que, nos versos que seguem, alude à ancestral relação entre o sagrado, a criança e a palavra. 
(...)

Um dia que outro eu contei para a Mãe que tinha visto

um passarinho a mastigar um pedaço de vento. A Mãe

disse outra vez: Já vem você com sua visões! Isso é

travessura da sua imaginação.

É a voz de Deus que habita nas crianças, nos passarinhos

e nos tontos.

A infância da palavra. (BARROS, 2010, p. 19)

No tocante à segunda parte do livro, encontra-se uma poesia com altíssimo grau de condensação e significação. Em alguns casos, não seria incorreto pensar que se trata de uma espécie de haikai tupiniquim, poemas-versos como o de número 27: "Eu vivo no meu relento." (BARROS, 2010, p. 77), transmitem claramente tal ideia.

Sabe-se também que trabalhar "com literatura infantil em sala de aula é criar condições para que se formem leitores de arte, leitores de mundo, leitores plurais. (...) é ampliar a competência de ver o mundo e dialogar com a sociedade." (GREGORIN FILHO, 2009, p. 77). Assim, poder-se-ia problematizar também se o relento em que vive o "eu" poético poderia servir de catalisador para possibilitar a (com)vivência entre os homens.

Antonio Cândido, em sua obra Literatura e Sociedade, discorrendo sobre a relação entre o artista e o meio, cita Sainte-Beuve, lembrando que:

O poeta não é uma resultante, nem mesmo um simples foco refletor; possui o seu próprio espelho, a sua mônada individual e única. Tem o seu núcleo e o seu órgão, através do qual tudo o que passa se transforma, porque ele combina e cria ao devolver à realidade. ${ }^{27}$ (CANDIDO, 1985, p. 18)

Sob esse prisma, esta tese defende que a realidade devolvida ao leitor por Manuel de Barros compõe um mundo em que todos são meninos do mato, buscando extrair a essência da vida, no final das contas, de si mesmos, através da essência da palavra. E o poema selecionado para findar este breve subcapítulo pretende demonstrar que, embora "menino do mato", Manuel de Barros aborda questões complexas de teoria e crítica literária com simplicidade tamanha, capaz de se fazer entender mesmo pelos leitores de idade mais tenra, dada a poeticidade de sua abordagem:

"Minha professora me emprestou um livro do

${ }^{27}$ Apud René Bady. Introducion à l'étude de la littérature française. Éditions de la Librairie de I'Université, Friburgo, 1943, p. 31. 


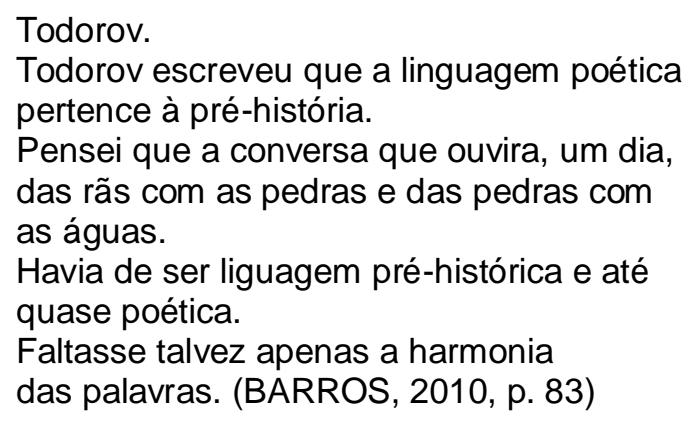

Ítalo Calvino, em sua texto Por que ler os clássicos?, pertencente à obra que recebe o mesmo título, na proposição de número 14 explicita o seguinte: "É clássico aquilo que persiste como rumor mesmo onde predomina a atualidade mais incompatível." (2007, p. 15). Coadunando com tal afirmação, pretende-se finalizar este subcapítulo reforçando o que se disse no início.

Assim, defende-se que a estética sob a qual a obra Menino do Mato é concebida proporciona ao leitor, por meio de uma construção metafórica paradoxal como o homem primitivo que produzia fogo a partir do atrito entre as pedras - que ele possa extrair a seiva das palavras, e, brincando, viajar no tempo para aquele lugar secreto que era só dele, encontrando-se, de modo sublime, natural, com a criança que foi.

2.2 - Fantasia em prosa e poesia nas Memórias inventadas: As infâncias de Manoel de Barros

Embora a ideia de infância geralmente remeta ao tempo de criança, ela também pode significar em grande medida, um estado de espírito. Isso porque, quando se recorre às reminiscências, não é incomum o imaginário conceber com traços de fantasia qualquer etapa da vida.

Em Memórias Inventadas: as infâncias de Manoel de Barros, o termo "infância" é utilizado no plural porque o poeta, segundo o texto da contracapa da obra $^{28}$, considera que todas as etapas de sua vida foram "infância". Talvez por esse motivo, a obra fora dividida em três partes, a saber: a primeira; a segunda; e a

\footnotetext{
${ }^{28}$ O poeta Manoel de Barros um dia pensou em publicar três livros. Um que tratasse da infância, outro da mocidade e mais um sobre a velhice. Depois que escreveu os três primeiros poemas e os publicou, no entanto, percebeu que não seria capaz de tratar dos outros dois assuntos. E ele explicou a razão com palavras muito simples e poéticas, como é seu costume. Disse: "Eu só tive infância". (...) (Texto extraído da contracapa de Memórias Inventadas: as infâncias de Manoel de Barros; edição publicada em 2008.)
} 
terceira infância. A primeira contemplando de fato o tempo de criança do poeta, a segunda, a sua mocidade e a terceira, a sua velhice.

Por esse motivo, divide-se a abordagem também em três partes, com o intuito de contemplar da forma mais acurada possível aspectos da obra. Antes, porém, ressaltam-se características comuns às três partes. Do ponto de vista da estrutura verbal, Manoel de Barros produz um gênero híbrido, um misto de prosa e poesia. Trata-se de breves narrativas poéticas e com temáticas independentes umas das outras, desenhando cenários que, em sua totalidade, representam a construção poética da vida do poeta.

Optou-se pela expressão "construção poética" e não "retrato biográfico", por exemplo, por se considerarem as palavras

(...) objetos que, nas mãos do poeta, excitam a imaginação e se transformam em obras de arte. Inócuas as mais das vezes, é após levadas pela imaginação que elas se tornam belas e significativas. Contudo, não devemos esquecer que foram todas criadas por poetas. E não há nenhuma contradição nisso: é das palavras, voláteis, perderem-se no mundo tão logo nascidas. A imaginação do poeta é que as revivifica: as coisas, sabe-se, não existem antes que sua mão as toque. (BRASILEIRO, 2002, p. 103)

Dessa forma, Manoel de Barros estrutura uma obra capaz de ilustrar pontualmente um dos pontos mais importantes defendidos por esta pesquisa, de que a literatura infantil e juvenil é acima de tudo literatura, pois a estética verbal de Memórias Inventadas: As infâncias de Manoel de Barros lhe permite transcender o engessamento das classificações, podendo ser oferecida a leitores de todas as idades.

Tal fato colabora grandemente para se defender, entre outros aspectos, a contemporaneidade da obra por se entender que ela atende às demandas contemporâneas no que concerne ao público infantil e também juvenil, uma vez que

\footnotetext{
No mosaico que é o mundo atual, em que se encontram agrupamentos humanos nos mais diversos estágios de desenvolvimento social, tecnológico e cultural, ainda existem sociedades que possuem concepções mais tradicionais e, por que não dizer, ancestrais de convivência com a juventude e conservam alguns rituais primitivos de passagem da vida juvenil para a adulta. (GREGORIN FILHO, 2011, p. 16)
}

Talvez o fato de o autor dividir a obra em três "infâncias" sinalize sua crença na divisão da vida em etapas, o que se assemelharia muito aos ritos de passagem de outrora. Todavia, a poesia de Manoel de Barros busca extrair a infância que 
reside nas especificidades de cada uma dessas etapas, valendo-se de metáforas, paradoxos e sinestesias cuja delicadeza, beleza e ternura buscam desenhar para o leitor memórias que, embora inventadas, não deixam de ser repletas de fantasia.

\subsection{1 - O menino}

A primeira parte da obra - A primeira infância - construída por pequenas narrativas híbridas, será denominada "contos poéticos", dada a alternância estrutural entre parágrafos, estrofes e versos no mesmo corpo textual. Como a configuração da maior parte dos textos está em prosa, ao contrário da maioria das obras de Manoel de Barros, entende-se haver a primazia da utilização de um narrador personagem ao invés de um "eu" poético, não considerando a obliteração completa do "eu" poético, pois em alguns textos prevalece a estrutura poética sobre a prosaica.

No texto de abertura da primeira parte - Escova (Anexo V) - a metáfora do arqueólogo indica ao leitor a cor que predominará na temática geral da primeira parte, ou seja, o menino que, mesmo num primeiro momento demovido pelos outros da ideia de escovar as palavras, já traçara seu destino:

(...) Eu queria ir atrás dos clamores antigos que estariam guardados dentro das palavras. Eu já sabia também que as palavras possuem no corpo muitas oralidades remontadas e muitas significâncias remontadas. Eu queria então escovar as palavras para escutar o primeiro esgar de cada uma. Para escutar os primeiros sons, mesmo que ainda bígrafos. (...) (BARROS, 2008, p. 21)

O narrador personagem descreve para o leitor o desejo de buscar a essência, a ancestralidade da palavra, seus sons mais profundos, sua alma, conduzindo-o, indiretamente, para o universo poético, pois a "(...) visão pura e simples descobrenos um mundo plano, sem mistérios. A visão indireta é a única via para o maravilhoso." (TODOROV, 2007, p. 130).

Pode-se inferir que toda a primeira parte se metamorfoseia num grande exercício do olhar, juntamente com o narrador. O leitor recebe da avó uma preciosa lição, a de "(...) não desprezar as coisas desprezíveis e nem os seres desprezados." (BARROS, 2008, p. 23). Narrador e leitor são convidados a uma atitude plena de empatia. 
Manoel de Barros cultiva a habilidade de, por meio de uma simplicidade narrativa, abordar conceitos complexos. O terceiro conto poético - Desobjeto (Anexo $\mathrm{VI}$ ) - ilustra tal metodologia, pois facilmente dialoga com a parábola de "Agassiz e do peixe", apresentada por Ezra Pound em $A B C$ da Literatura.

\begin{abstract}
Um estudante de curso de pós-graduação, coberto de honrarias e diplomas, dirigiu-se a Agassiz para receber os ótimos e últimos retoques. O grande naturalista tomou um peixinho e pediu-lhe que o descrevesse.

Estudante: - Mas este é apenas um peixe-lua.

Agassiz: - Eu sei disso. Faça uma descrição dele por escrito.

Depois de alguns minutos o estudante voltou com a descrição do Ichtus Heliodiplodokus ou outro termo qualquer, desses usados para sonegar do conhecimento geral o vulgar peixe-lua: família dos Hellichtherinkus, etc., como se encontra nos manuais sobre $o$ assunto.

Agassiz pediu ao estudante que descrevesse de novo o peixe.

O estudante perpetrou um ensaio de quatro páginas. Agassiz então the disse que olhasse para 0 peixe. No fim de três semanas o peixe se encontrava em adiantado estado de decomposição, mas o estudante sabia alguma coisa a seu respeito. (POUND, 2006, p. 23-24)
\end{abstract}

Observa-se, entretanto, que o narrador personagem de Manoel de Barros vai além da simples observação do objeto - no caso do conto, um pente -, pois, esgotado o processo de observação do pente em estado terminal, o menino alça-o para outro universo ao mesmo tempo poético e em estado pleno de comunhão com a natureza:

(...) O menino que era esquerdo e tinha cacoete pra poeta, justamente ele enxergara o pente naquele estado terminal. E o menino deu para imaginar que o pente, naquele estado, já estaria incorporado à natureza como um rio, um osso, um lagarto. Eu acho que as árvores colaboravam na solidão daquele pente. (BARROS, 2008, p. 27)

Interessante pensar que essa possibilidade de mutação flui harmonicamente para a criança, ou seja, é muito fácil para ela imaginar o pente incorporado à natureza, porque

No mundo infantil, a possibilidade de mutação é constante, diferente do mundo adulto, escolarizado e profissionalizado. Não faz sentido para uma criança haver nome de gente e nome de coisas, a sonoridade é o que importa, a rima, como na poesia. (SCOFANO; MAIA, 2018, p. 100)

O narrador prossegue apresentando ao leitor a beleza da poesia que aflora a partir do processo de subversão do sentido denotativo das palavras. Embora se saiba que o efeito tenha muito mais a ver com estética do que com simples 
brincadeira com as palavras, não é essa a impressão que o narrador transmite para o leitor. Aliás ele - o narrador - defende exatamente o contrário.

(...) eu acho que buscar a beleza nas palavras é uma solenidade de amor. E pode ser instrumento de rir. De outra feita, no meio da pelada um menino gritou: Disilimina esse, Cabeludinho. Eu não disiliminei ninguém. Mas aquele verbo novo trouxe um perfume de poesia à nossa quadra. Aprendi nessas férias a brincar de palavras mais do que trabalhar com elas. Comecei a não gostar de palavra engavetada. Aquela que não pode de lugar. Aprendi a gostar mais das palavras pelo que elas entoam do que pelo que elas informam. (...)(BARROS, 2008, p. 41)

No subcapítulo anterior, apontou-se que nO Menino do Mato havia um quintalmundo criado por Manoel de Barros que dava à obra caráter universal. Agora, em um dos poucos poemas de Memórias Inventadas, Manoel de Barros compõe um de seus poemas mais emblemáticos - O apanhador de desperdícios -. Nele, o "eu" poético evidencia para o leitor traços fulcrais de uma estética que harmoniza fantasia, brincadeira com as palavras e a possibilidade de visitar, entre lugares, outro mundo para além da percepção física das coisas.

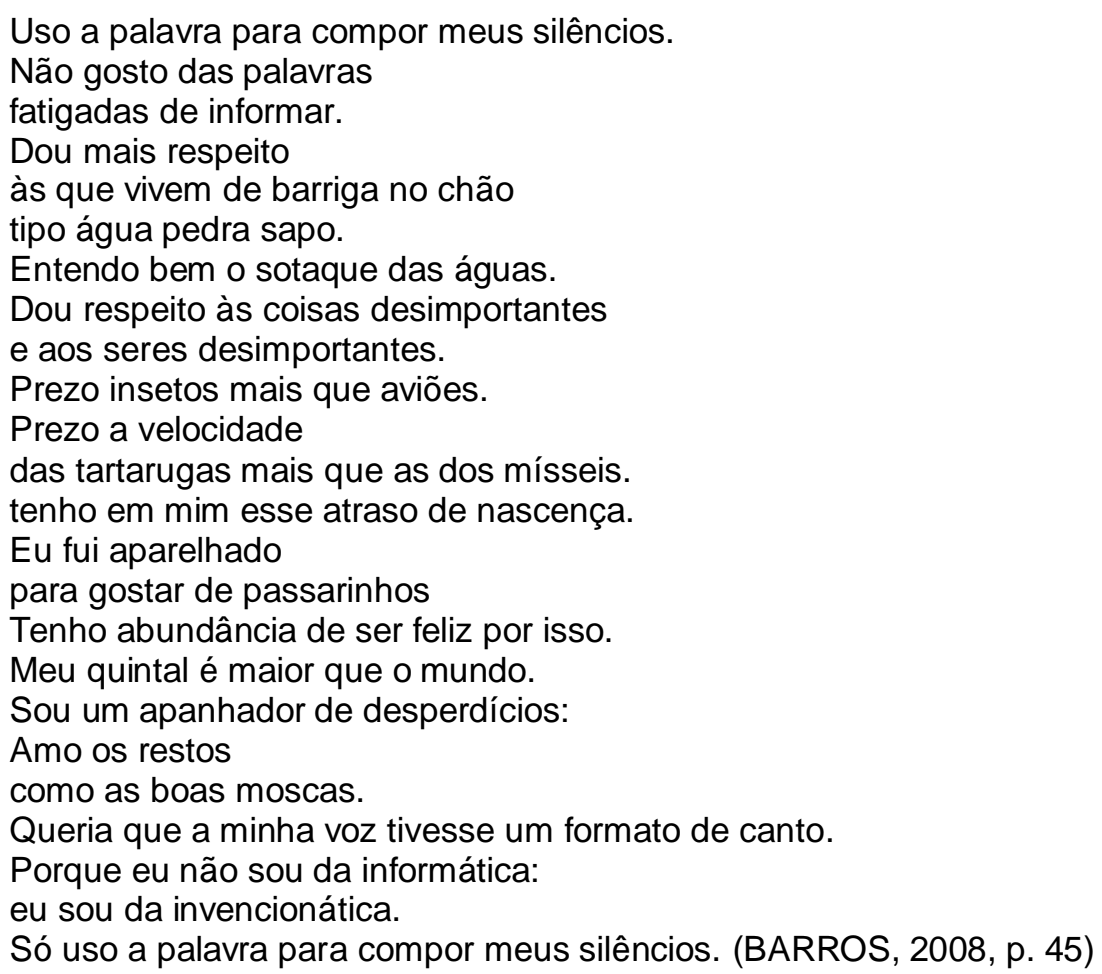

Essa profunda relação com as miudezas e as coisas desimportantes pretende aguçar no leitor a percepção de uma relação simbiótica entre o homem, a natureza e a palavra. Manoel de Barros seja por meio do "eu" poético seja por meio do narrador 
personagem alimenta uma quase obsessão pela busca da palavra inaugural, dialogando com a afirmação de Heidegger: "A linguagem é a casa do ser. Em seu abrigo, mora o homem. Os pensadores e os poetas são aqueles que guardam este abrigo."29

(...) Sendo que a importância de uma coisa ou de um ser não é tirada pelo tamanho ou volume do ser, mas pela permanência do ser no lugar. Pela primazia. Por esse viés do primordial é possível dizer então que a pedra é mais importante do que o homem. (BARROS, 2008, p. 51)

A importância medida pela primazia e ou pela permanência do ser no lugar é outra forma metafórica de recorrer ao caráter essencial das coisas. Além disso, no conto poético "Latas" (Anexo VII), Manoel de Barros retoma a questão da decomposição como redenção, isto é, assim como a metáfora do pente mencionada anteriormente, as latas se tornam poesia à medida que entram em comunhão com a natureza, ou melhor, voltam para ela, livrando-se de “(...) todos os ranços (e artifícios) da indústria que as produziu." (BARROS, 2008, p. 57).

Além da importância, Manoel de Barros também abordará o tamanho das coisas sob uma perspectiva poética. Segundo o narrador, no conto poético "Achadouros" (Anexo VIII), a “(...) gente descobre que o tamanho das coisas há que ser medido pela intimidade que temos com as coisas. Há de ser como acontece com o amor." (BARROS, 2008, p. 59). Percebe-se, por meio dos últimos exemplos, que nos últimos contos poéticos pertencentes à primeira parte o narrador começa a adotar uma abordagem mais metafísica e filosófica.

Entretanto, embora não atendendo, do ponto de vista da estrutura, ao gênero poesia, do ponto de vista da linguagem a brincadeira com as palavras continua. Nesse sentido não seria incorreto inferir que a estética de Manoel de Barros, no que tange à poesia infantil e juvenil, atende ao aspecto mais relevante que é

(...) o fato de jogar com as palavras, ordenando-as de forma harmoniosa, revestindo-as de mistério, e de maneira tal que cada imagem passa a conter a solução de um enigma. Na construção poética, portanto, as palavras, ferramentas do poeta, não são usadas de modo habitual, metamorfoseiamse nas mãos do artesão, sofrem transformações que revelam liberdade de criação. Organizadas de maneira própria, com ampla significação, para além do óbvio e do previsível, tornam-se símbolos do real, requisito fundamental na construção da imagem poética. Um dos tópicos mais

${ }^{29}$ HEIDEGGER. Über den Humanismus (Lettre sur l'umanisme (bilíngue), p. 26. Vale a pena confrontar a tradução francesa: Le language est la Maison de l'Être. Dans son abri, habite l'homme. Les penseurs et les poètes sont ceux qui veillent sur cet abri. 
reconhecidos da linguagem literária é sua capacidade de evocação e conotação, o uso de imagens e símbolos, afastando qualquer possibilidade de representação lógica de conceitos ou da realidade. (MARTHA, 2012, p. 46)

Tal aspecto pode ser ilustrado pelo trecho do último conto poético da primeira parte - Sobre Sucatas (Anexo IX) - em que o narrador contrapõe a efemeridade das invenções do homem em relação à perenidade dos elementos da natureza, tomada como verdade poética, da qual o narrador, apesar de se desculpar por revelar ao leitor, abre-lhe as portas para a mocidade, ou melhor, para a segunda infância:

(...) O mundo era um pedaço complicado para o menino que viera da roça. não vi nenhuma coisa mais bonita na cidade do que um passarinho. Vi que tudo o que o homem fabrica vira sucata: bicicleta, avião, automóvel. Só o que não vira sucata é ave, árvore, rã, pedra. Até nave espacial vira sucata. Agora eu penso uma garça branca de brejo ser mais linda que uma nave espacial. Peço desculpas por cometer essa verdade. (BARROS, 2008, p. 63)

\subsection{2 - O jovem-menino}

Experiências sexuais, intensificação das relações de amizade, o ambiente escolar, além da constante busca pela comunhão com a natureza são os temas que compõem a segunda infância das Memórias Inventadas. Embora alguns deles dialoguem grandemente com os da primeira infância, é preciso ressaltar o aprofundamento reflexivo da abordagem, com menções a físicos e filósofos, por exemplo, e o rebuscamento da linguagem, pressupondo um leitor um tanto mais amadurecido, entretanto sem perder a fantasia da infância.

A estrutura narrativa também predomina nessa segunda parte, todavia com lampejos de poesia, manifestados pela exploração dos jogos de palavras, das metáforas, da incessante busca pela essência do sentido das palavras e da comunhão com a natureza, típicas da confecção verbal de Manoel de Barros.

Confecção verbal esta que apresenta ao leitor imagens cujos “(...) arquétipos funcionam como intermediários entre os esquemas subjetivos $e$ as imagens produzidas pelo ambiente perceptivo. Aqui se dá o ponto de articulação entre o imaginário e a razão." (SCOFANO; MAIA. 2016, p. 103). Defende-se que, por meio de tal ponto de articulação, emergem a ternura, a beleza e a fantasia, como se ilustrará a partir do texto a seguir, o primeiro da segunda parte: "Estreante": 
Fui morar numa pensão na rua do Catete.

A dona era viúva e buliçosa

E tinha uma filha indiana que dava pancas.

Me abatia.

Ela deixava a porta do banheiro meio aberta

$E$ isso me abatia.

Eu teria 15 anos e ela 25.

Ela me ensinava:

Precisa não afobar.

Precisa ser bem animal.

Como um cavalo. Nobremente.

Usar o desorgulho dos animais.

Morder lamber cheirar fugir voltar arrodear

lamber beijar cheirar fugir voltar

Até.

Nobremente. Como os animais.

Isso eu aprendi com minha namorada indiana.

Ela me ensinava com unguentos.

Passava unguento passava unguento passava unguento.

Dizia que era um ato religioso foder.

E que era preciso adornar os desejos com unguento.

E passava unguento e passava unguento.

Só depois que adornava bem ela queria.

Pregava que fazer amor é uma eucaristia.

Que era uma comunhão.

E a gente comungava o Pão dos Anjos. (BARROS, 2008, p. 71)

Poucos temas fascinam o leitor juvenil tanto quanto os que remetem às questões sexuais, seja pela curiosidade seja pelo despertar natural do desejo subjacente a essa fase da vida, caracterizada pela transição do universo infantil para o universo adulto. Entretanto o "eu" poético de Manoel de Barros não se atém apenas ao aspecto visceral inerente ao desejo e à realização do ato, mas ressalta, sobretudo, o aspecto sagrado, sublime, assegurando assim a fantasia e a humanização da experiência sexual e, consequentemente, do próprio indivíduo.

Todavia esse não parece ser o único desejo do narrador. No decorrer de outros textos da segunda parte, manifesta-se também o desejo de humanizar não apenas o homem, mas também de encontrar uma estética que seja capaz de desenhar poeticamente a natureza ao seu redor. O texto "Pintura" ilustra bem tais anseios:

(...) Um dia tentei desenhar as formas da Manhã sem lápis. (...) Por primeiro havia que humanizar a Manhã. Torná-la biológica. Fazê-la mulher. Antesmente eu tentara coisificar as pessoas e humanizar as coisas. Porém humanizar o tempo! Uma parte do tempo? Era dose. Entretanto eu tentei. Pintei sem lápis a Manhã de pernas abertas para o Sol. A manhã era mulher e estava de pernas abertas para o sol. Na ocasião eu aprendera em Vieira (Padre Antônio, 1604, Lisboa) eu aprendera que as imagens pintadas com 
palavras eram para se ver de ouvir. Então seria o caso de se ouvir a frase pra se enxergar a Manhã de pernas abertas? Estava humanizada essa beleza de tempo. E com os seus passarinhos, e as águas e o Sol a fecundar o trecho. Arrisquei fazer isso com a Manhã, na cega. Depois que meu avô me ensinou que eu pintara a imagem erótica da Manhã. Isso fora. (BARROS, 2008, p. 77)

Interessante pensar que o narrador personagem recorre à visão estética do Barroco, mais especificamente ao Padre Vieira, não apenas retomando a lição de um conceito do século XVI, mas transpondo-o no século XXI, dando a ele vivacidade contemporânea cinco séculos mais tarde.

Isso porque “(...) os temas e a estética presentes na obra literária devem ser tomados como representações artísticas da vida em sociedade em determinada cultura, não como a vida real que se está mostrando aos jovens." (GREGORIN FILHO, 2011, p. 76). Assim, defende-se que a configuração estética da literatura de Manoel de Barros assegura ao leitor a possibilidade de uma profunda reflexão acerca do universo ao qual ele pertence.

Para tanto, é "(...) importante que se entenda o importante papel que a literatura tem na humanização do indivíduo e da própria sociedade como promotora de reflexão e discussão de conflitos inerentes ao homem." (GREGORIN FILHO, 2011, p. 76).

Nesse cenário, Manoel de Barros traça, ao longo de toda segunda parte, mecanismos que buscam construir esteticamente experiências juvenis que, embora pareçam destoar do contexto líquido, tecnológico e digital que permeia a sociedade contemporânea, levam à aproximação de elementos que muitas vezes passam despercebidos aos olhos do jovem leitor, majoritariamente mergulhado no estado prosaico de Morin.

Para retirar o jovem leitor desse estado prosaico e the oferecer possibilidades de experimentar o estado poético, o trabalho estético que Manoel de Barros oferece põe a literatura em diálogo ora com a Arte, ora com a Filosofia e, apesar de exigir do leitor alguma bagagem cultural, desenha imagens que não apenas se harmonizam com os diálogos propostos, mas, sobretudo, transformam-nos em linguagem poética. Vejamos a seguir, dois exemplos:

O primeiro diz respeito ao texto poético "Oficina". Nele, o narrador e seu amigo de olhar descomparado criam a sua "Oficina de Desregular a Natureza". Nela, depois de criar vários objetos, como: "O parafuso de veludo", "O prego que farfalha" 
e "O alicate cremoso", encerra remetendo o leitor ao pintor espanhol Pablo Picasso: "E por último aproveitamos para imitar Picasso com A moça com o olho no centro da testa. Picasso desregulava a natureza, tentamos imitá-lo. Modéstia à parte." (BARROS, 2008, p. 79).

O segundo exemplo refere-se ao texto poético "Aprendimentos". O narrador evoca inicialmente Kiekkegaard e, em seguida, Sócrates, Platão e Aristóteles, dando a conceitos filosóficos clássicos tons poéticos capazes de torná-los menos complexos e mais belos e apetecíveis à percepção juvenil.

O filósofo Kiekkegaard me ensinou que cultura é o caminho que o homem percorre para se conhecer. Sócrates fez o seu caminho de cultura e ao fim falou que só sabia que não sabia nada. Não tinha as certezas científicas. Mas que aprendera coisas di-menor natureza. Aprendeu que as folhas das árvores servem para nos ensinar a cair sem alardes. (...) Eu vivi antigamente com Sócrates, Platão, Aristóteles - esse pessoal. Eles falavam nas aulas: Quem se aproxima das origens se renova. (...) Os mestres pregavam que o fascínio poético vem das raízes da fala. Sócrates falava que as expressões mais eróticas são donzelas. E que a beleza se explica melhor por não haver razão nenhuma nela. $O$ que de mais eu sei sobre Sócrates é que ele viveu uma ascese de mosca. (BARROS, 2008, p. 109)

Encerram-se as observações acerca da segunda infância abordando a construção poética de personagens que permearam a juventude do narrador: a velha paraguaia Nhá Velina Cuê $\hat{e}^{30}$, que apresentara ao narrador o termo "Bocó" com o qual "ele se estimou"; os moradores do "Desprezo"31, em especial à dona Ana Belona, que "queria ser árvore para ter gorjeios" e não "queria mais moer solidão"; o índio Guató Rogaciano ${ }^{32}$, que encantou o narrador com seu não saber gramatical; o professor de latim, Mestre Aristeu ${ }^{33}$, que se cansou de ensinar as desinências e passou a falar de poesia; A namorada ${ }^{34}$, "que via errado" e "despraticava as normas", poetizando o olhar do narrador; o doutor ${ }^{35}$, "formado de São Paulo", "Almofadinha", que quis se certificar se o adolescente e rebelde narrador "endireitou".

Todos esses personagens permeiam o imaginário do narrador, garantindo sua vivência social, fator de suma importância, pois

\footnotetext{
${ }^{30}$ BARROS, 2018, p. 83

${ }^{31}$ BARROS, 2018, p. 89

32 BARROS, 2018, p. 91

${ }^{33}$ BARROS, 2018, p. 97

${ }^{34}$ BARROS, 2018, p. 103

${ }^{35}$ BARROS, 2018, p. 115
} 
(...) talvez não haja equilíbrio social sem literatura. Desse modo, ela é fator indispensável da humanização e, sendo assim, confirma o homem na sua humanidade, inclusive porque atua em grande parte do subconsciente e no inconsciente. Nesse sentido, ela pode ter a importância equivalente às formas conscientes do inculcamento intencional, com a educação familiar, grupal ou escolar. Cada sociedade cria suas manifestações ficcionais, poéticas e dramáticas de acordo com seus impulsos, as suas crenças, os seus sentimentos, as suas normas, a fim de fortalecer em cada um a presença e atuação deles. (CANDIDO, 2004, p. 175)

O último texto poético da segunda infância - Pelada de barranco ${ }^{36}$ - narra uma partida de futebol entre amigos, entretanto destacaremos a afirmação do narrador na primeira linha do conto poético: "Nada havia de mais prestante em nós senão a infância.". A partir dela o narrador apresenta a descrição de uma partida de futebol, metáfora de momentos preciosos de outrora, em que havia plenitude, fraternidade, empatia nas relações. Índios, filhos de lavadeiras, filhos de pescadores, todos eram iguais, havendo espaço para apenas uma classificação: meninos.

Será abordada agora "A Terceira Infância", última parte das Memórias Inventadas. Trata-se do ponto de vista quantitativo, da menor parte das três, entretanto dotada da mesma intensidade e beleza. A composição verbal de Manoel de Barros mantém a estrutura narrativa na maioria das composições, que se denominam desde o início das análises de "contos poéticos". Neles, a fantasia reside no desenho das reminiscências do narrador.

\subsection{3 - O velho-menino}

Iniciam-se as considerações sobre a terceira e última parte das Memórias inventadas abordando a simbologia acerca da velhice. Segundo o Dicionário de Símbolos, ela é a "(...) prefiguração da longevidade, um longo acúmulo de experiência e de reflexão, (...) uma imagem imperfeita da imortalidade." (CHEVALIER; GHEERBRANT. 2007, p. 934).

O narrador em Manoel de Barros, talvez exercendo esse "longo acúmulo de experiência e de reflexão", recorre a um dos conceitos poéticos mais ancestrais, controversos e enigmáticos da literatura: o da inspiração. Ao denominar "Fontes" ${ }^{37}$ o primeiro texto, o poeta deixa clara a necessidade de mencionar suas principais

\footnotetext{
${ }^{36}$ BARROS, 2018, p. 119

${ }^{37}$ BARROS, 2008, p. 125
} 
fontes de inspiração, responsáveis por representar a fantasia ao longo de toda a obra, a saber: a criança, os passarinhos e os andarilhos. Eis o texto:

Três personagens me ajudaram a compor estas memórias. Quero dar ciência delas. Uma, a criança; dois, os passarinhos; três, os andarilhos. A criança me deu a semente da palavra. Os passarinhos me deram o desprendimento das coisas da terra. $E$ os andarilhos, a preciência da natureza de Deus. Quero falar primeiro dos andarilhos, do uso em primeiro lugar que eles faziam da ignorância. Sempre eles sabiam tudo sobre o nada. E ainda multiplicavam o nada por zero - o que lhes dava uma linguagem de chão. Para nunca saber onde chegavam. E para chegar sempre de surpresa. Eles não afundavam estradas, mas inventavam caminhos. Essa a pré-ciência que sempre vi nos andarilhos. Eles me ensinaram a amar a natureza. Bem que eu pude prever que os que fogem da natureza um dia voltam para ela. Aprendi com os passarinhos a liberdade. Eles dominam o mais leve sem precisar ter motor nas costas. $\mathrm{E}$ são livres para pousar em qualquer tempo nos lírios ou na pedra - sem se machucarem. E aprendi com eles ser disponível para sonhar. O outro parceiro sempre foi a criança que me escreve. Os pássaros, os andarilhos e a criança em mim são meus colabores destas. (BARROS, 2008, p. 127)

De fato, esses três elementos - criança, passarinhos e andarilhos protagonizam as construções imagéticas dos textos que constituem a terceira parte. Nela, o poeta vale-se do aspecto de liberdade presente em cada um deles para construir, nos cenários narrativos dos contos poéticos, um universo ficcional de fantasia capaz de instigar a percepção do leitor.

Dessa forma, Manoel de Barros faz brotar, do imaginário do narrador personagem, reminiscências que pretendem proporcionar ao leitor um ambiente onde

“(...) não se faz distinção entre cenários que correspondem a lugares possíveis ou puramente imaginários, mas especificou-se um item de lugar fantástico no qual se incluem cenários, que não pretendem reproduzir o mundo real, nem que apenas atribuem a ele algum elemento fantástico, mas que supõem um lugar impossível, como o é, por exemplo, a situação de uma cena no interior da folha de um livro." (COLOMER, 2003, p. 199)

É o que se pode perceber no poema "Invenção"38, em que o "menino levado da breca" brinca com a sua própria (in)existência, iluminando para o leitor uma relação de alteridade do "eu" poético consigo mesmo, ou seja, a fantasia não reside necessariamente num lugar propriamente dito, mas no jogo entre ser ou não ser:

Inventei um menino levado da breca para me ser.

${ }^{38}$ BARROS, 2008, p. 129 
Ele tinha um gosto elevado para o chão.

De seu olhar vazava uma nobreza de árvore.

Tinha desapetite para obedecer a arrumação das

coisas.

Passarinhos botavam primaveras nas suas palavras.

Morava em maneira de pedra na aba de um morro.

O amanhecer fazia glória em seu estar.

Trabalhava sem tréguas como os pardais bicam as tardes.

(...)

Porém o menino levado da breca ao fim me falou

que ele não fora inventado por esse cara poeta

Porque fui eu que inventei ele. (BARROS, 2008, p. 129)

Manoel de Barros prossegue valendo-se da interdiscursividade e, assim como na segunda parte, faz referência ao Padre Antônio Vieira, evidenciando dessa vez a estética do poeta barroco. No conto poético "Jubilação" ${ }^{39}$ o narrador manifesta seu desejo de aproximar-se esteticamente do modo como Padre Antônio Vieira trabalhava a palavra:

Tenho gosto de lisonjear as palavras ao modo que o Padre Vieira lisonjeava. Seria uma técnica literária do Vieira? É visto que as palavras lisonjeadas se enverdeciam para ele. Eu uso essa técnica. Eu lisonjeio as palavras. E elas até me inventam. E elas se mostram faceiras para mim. (...) A gente não gostasse de fazer nada que não fosse brinquedo. Essas vadiagens pelos recantos do idioma seriam só fazer jubilação com as palavras. Tirar delas algum motivo de alegria. Uma alegria de não informar nada de nada. (...) A gente brincava no prateado das águas. A mais pura jubilação! (BARROS, 2008, p. 133)

O poema acima ilustra bem a filosofia poética e estética de Manoel de Barros, pois, como se mencionou no início desta tese, o autor procura harmonizar as funções metalinguísticas e poéticas, equilibrando-as sempre que possível, fazendo eclodir dessa tentativa de equilíbrio a fantasia que reside em sua obra, os lampejos de poeticidade que pretendem tocar o imaginário do leitor.

Sob esse prisma, acredita-se ainda que, das metáforas construídas pela estética literária do poeta mato-grossense, bem como nos

(...) lábios de crianças, loucos, sábios, cretinos, apaixonados ou solitários brotam imagens, jogos de palavras, expressões surgidas do nada. Por um instante, brilham ou relampejam. Depois se apagam. Feitas de matéria inflamável, as palavras ardem no instante em que são tocadas pela imaginação ou pela fantasia. Mas são incapazes de guardar seu fogo. (PAZ, 2012, p. 43)

${ }^{39}$ BARROS, 2008, p. 133 
Outro aspecto presente na terceira parte, que deve ser ressaltado, ainda refletindo sobre a estética de Manoel de Barros, diz respeito ao modo como o poeta prossegue criando metáforas a partir da confluência entre a criança e a natureza valendo-se de uma linguagem que transcende o conceito de oralidade, buscando tocar a ancestralidade, ou seja, o seu sentido primeiro. É o que se percebe no conto "Formação" 40 :

Fomos formados no mato - as palavras e eu. O que de terra a palavra se acrescentasse, a gente se acrescentava de terra. O que de água a gente se encharcasse, a palavra se encharcava de água. Porque nós íamos crescendo de em par. Se a gente recebesse oralidade dos pássaros, as palavras receberiam oralidades de pássaros. Conforme a gente recebesse formatos da natureza, as palavras incorporavam as formas da natureza. Em algumas palavras encontramos subterrâncias de caramujos e de pedras. Logo as palavras se apropriavam daqueles fósseis linguísticos. Se a brisa da manhã despetalasse em nós o amanhecer, as palavras amanheciam. Podia se dizer que a gente estivesse pregado na vida das palavras ao modo que uma lesma estivesse pregada na existência de uma pedra. Foi no que deu a nossa formação. Voltamos ao homem das cavernas. Ao canto inaugural. Pegamos na semente da voz. Embicamos na metáfora. Agora a gente só sabe fazer desenhos verbais com imagens. Tipo assim: Hoje eu vi outra rã sentada sobre uma pedra ao jeito que uma garça estivesse sentada de tarde na solidão de outra pedra. Foi no que deu a nossa formação. Eu acho bela. Eu acompanho. (BARROS, 2008, p. 145)

De forma didática, sem deixar de ser poética, Manoel de Barros apresenta ao leitor sua forma de conceber a palavra, realçando, sobretudo, além da relação propriamente dita, a beleza do processo. Tal pensamento dialoga profundamente não só com a possibilidade de produzir encantamento no leitor, mas também com a definição oferecida por Octavio Paz:

A fala é a substância ou alimento do poema, mas não é o poema. A diferença entre o poema e essas expressões poéticas - inventadas ontem ou repetidas há mil anos por um povo que mantém intacto seu saber tradicional - reside no seguinte: o primeiro é uma tentativa de transcender o idioma; as expressões poéticas, por sua vez, vivem no mesmo nível da fala e são resultado do vaivém das palavras na boca dos homens. Não são criações, obras. A fala, a linguagem social, se concentra no poema, se articula e levanta. O poema é linguagem erguida. (PAZ, 2012, p. 43)

E também por Heidegger, especialmente no que concerne ao que se entende ser a tentativa de produzir a fantasia por meio da constante busca da ancestralidade da palavra, de sua origem lustral, epifânica, enigmática, sagrada:

${ }^{40}$ BARROS, 2008, p. 145 
O pensamento, dócil à voz do ser, procura encontrar-lhe a palavra através da qual a verdade do ser chegue à linguagem. Apenas quando a linguagem do homem historial emana da palavra, está ela inserida no destino que lhe foi traçado. Atingido, porém, este equilíbrio em seu destino, então lhe acena a garantia da voz silenciosa de ocultas fontes. O pensamento do ser protege a palavra e cumpre nesta solicitude seu destino. Este é o cuidado pelo uso da linguagem. O dizer do pensamento vem do silêncio longamente guardado e da cuidadosa clarificação do âmbito nele aberto. De igual origem é o nomear do poeta. Mas, pelo fato de igual somente ser igual enquanto é distinto, e o poetar e o pensar terem a mais pura igualdade no cuidado da palavra, estão ambos, ao mesmo tempo, maximamente separados em sua essência. $O$ pensador diz o ser. O poeta nomeia o sagrado. (HEIDEGGER, 1979, p. 51)

Menciona-se o filósofo Heidegger porque, caminhando para o final das considerações acerca da terceira parte da obra Memórias Inventadas, serão abordadas num primeiro momento as relações entre poesia e filosofia estabelecidas pelo "eu" poético e a relação interdiscursiva construída por Manoel de Barros em dois dos últimos textos da terceira parte: "Corumbá revisitada" ${ }^{41}$ e "Soberania" ${ }^{42}$ (Anexo IX).

No primeiro, a visão que o "eu" poético apresenta ao leitor em relação à vida relaciona-se com o princípio socrático do "Só sei que nada sei", entretanto, como já assinalou Heidegger, o poeta não apenas "diz o ser", ele "nomeia o sagrado" e o cuidado que o "eu" poético tem com a palavra é que produz a beleza e a fantasia para o leitor. Esse cuidado pode ser ilustrado pela última fala do narrador: "Agora não quero saber mais nada, só quero aperfeiçoar o que não sei." (BARROS, 2008, p. 137).

Considera-se que a beleza da imagem poética reside no ato de se aperfeiçoar o que não se sabe. Tal ato vai além da consciência de não se saber nada. $O$ exercício do aperfeiçoamento por si só metaforiza a necessidade da constância do fazer poético, o que, quando produzido, pode alimentar o imaginário do leitor.

Quanto ao segundo texto, o narrador mais uma vez evoca reminiscências de sua meninice - ou as inventa, afinal estamos falando de Memórias Inventadas, termo paradoxal (e poético) por si só - e nelas o menino que já brincava com as palavras, diante do "sorriso carinhoso" da mãe e das "gaitadas" dos irmãos, ouviu a teoria do pai, de que tivera "um vareio da imaginação", e seguiu o conselho dele: foi estudar.

${ }^{41}$ BARROS, 2008, p. 137
${ }^{42}$ BARROS, 2008, p. 152 
Aqui cabe um trecho do texto que, dada a potência de sua poeticidade, vem ao encontro do que se propôs defender neste subcapítulo: a tese de que a construção da fantasia em prosa ou poesia é a ferramenta mais eficaz para alimentar o imaginário, o gosto e formar o leitor literário.

A experiência estética pode propiciar o reencontro com a capacidade criadora, vencendo o medo de pensar e permitindo ao indivíduo descobrir o saber. É de grande relevância para a problemática desse trabalho a compreensão de uma educação estética, pelo viés da arte-educação, o qual seja instrumento de construção de aprendizagens, que propicie a subjetividade, o espaço de criação dos ensinantes/aprendentes, a mediação entre o pensar e o sentir e colabore no desaprisionamento da inteligência. (Vieira; Maia, 2015)

Eis o exemplo do "desaprisionamento da inteligência" do menino de outrora descrito pelo narrador:

(...) E dei de estudar pra frente. Aprendi a teoria das ideias e da razão pura. Especulei filósofos e até cheguei aos eruditos. Aos homens de grande saber. achei que os eruditos nas suas altas abstrações se esqueciam das coisas simples da terra. Foi aí que encontrei Einstein (ele mesmo - o Alberto Einstein). Que me ensinou essa frase: A imaginação é mais importante do que o saber. Fiquei alcandorado! E fiz uma brincadeira. Botei um pouco de inocência na erudição. Deu certo. Meu olho começou a ver de novo as pobres coisas do chão mijadas de orvalho. (...) E vi que o homem não tem soberania nem para um bentevi. (BARROS, 2008, p. 153)

\section{3 - Palavra-brinquedo: infância poética entre as Ignorãças e o Nada}

Brincar constitui uma das maiores preocupações e ou prioridades para crianças. Quaisquer objetos tocados pelas mãos delas, mesmo os mais inusitados, transformam-se em brinquedo; com as palavras, não seria diferente. Com elas

(...) aprendemos a transgredir a gramática, a errar e a recriar a língua. $\mathrm{Na}$ primeira instância do ser, há fantasia, imaginação. Essa força criadora é explorada e criam-se, então, jogos sonoros, imagens exuberantes que aliam - significante ao significado. Dessa forma, instaura-se uma linguagem adâmica. (BÉDA, 2007, p. 123)

O objetivo deste subcapítulo é ressaltar o modo como Manoel de Barros faz das palavras brinquedo, defendendo assim o quanto a proposta estética do poeta,

${ }^{43}$ VIEIRA, C. N. M.; MAIA, M. V. C. M. "A estética como via de nutrir o saber." In: Trama para https://www.cp2.g12.br/ojs/index.php/trama/article/download/165/126. Acesso em: 14 out. 2019. 
ao provocar subversão no sentido denotativo das palavras, dialoga com o universo da criança estabelecendo reciprocidade tal, capaz de conectá-la à palavra poética como se fosse uma grande brincadeira.

Anteriormente já se viu que a estética de Manoel de Barros busca extrair a essência das palavras, sua sonoridade e sentidos inaugurais. Agora se verá, por meio da análise das obras $O$ livro das Ignorãças e o Livro sobre Nada, que esse processo é possível porque o

(...) poeta olha o mundo com um olhar novo, como se o visse pela primeira vez, como fazem as crianças e como nós, adultos, desaprendemos fazer. [...] O leitor, em contato com o poema, revive essa capacidade de ter um olhar inaugural. (SILVA, 2009, p. 100)

Intenta-se que a arquitetura verbal de Manoel de Barros não apenas se vale desse olhar como também, por meio dele, faz sua construção poética sofisticada e travestida de brincadeira ao mesmo tempo, procurando, no leitor, “(...) estimular a introspecção e o olhar inaugural sobre as coisas por meio da sensibilidade, o que implicaria efeitos imagísticos e melódicos da parte do poema, capazes de alterar seus padrões perceptivos." (BORDINI, 2009, p. 157).

Ressalta-se ainda que tal característica não está apenas presente nas duas obras que serão contempladas neste subcapítulo. O que nelas chamou a atenção é o desejo manifestado acentuadamente pelo "eu" poético de evidenciar a palavra como brinquedo e, mais do que isso, de atribuir a essa condição, principal característica para que ela - a palavra - seja considerada poética: "Palavra poética tem que chegar ao grau de brinquedo para ser séria." (BARROS, 1996, p. 71).

Entende-se também que, em várias ocasiões, o poeta mato-grossense fornece ao leitor traços fundamentais de sua produção poética, daí o caráter metalinguístico de sua obra. Mas também não seria incorreto inferir que Manoel de Barros fornece material de caráter crítico acerca de si mesmo, não raro explicitando ao leitor como se dá a construção poética de determinada obra, como o faz em Livro sobre Nada, por meio do texto "Pretexto" (Anexo X), por exemplo, caminhando por uma tênue linha entre a produção e a crítica literária.

E tanto no caso dO livro das ignorãças quanto no do Livro sobre Nada, a temática da poesia de Manoel de Barros dialoga com o conceito estudado por 
Huizinga $(1971)^{44}$, que diz respeito à ligação entre poesia e jogo nas sociedades primitivas. Nas palavras de Alice Áurea Penteado Martha:

(...) observa que a atividade poética tem como berço o jogo sagrado, marcado sempre pela alegria e divertimento; depois, a poesia manifesta-se também nos jogos do relacionamento amoroso, na competição, na profecia, destacando-se, em todas as modalidades, o rigoroso, o cuidadoso código escrito, embora com variação infinita. As potencialidades dessa atividade lúdica equiparam-se às da criação poética, e as afinidades entre poesia e atividade lúdica podem ser observadas na própria estrutura da imaginação criadora, pois, como o jogo, a poesia coloca-se além do lógico, dos padrões preestabelecidos, do convencional. Nessa aproximação predomina a liberdade de criação, pois a construção poética, dotada de elementos que aproximam a arte do lúdico, reorganiza a palavra, mediante ordenação rítmica ou simétrica, nem sempre seguindo a ordem manifesta no mundo real. (MARTHA, 2012, p. 47)

Embora relativamente longa tal definição configura-se imprescindível para abordagem das obras a seguir, isso porque brincar com as palavras transcende questões de estética quando se trata da poesia de Manoel de Barros. Para ele, tratase de um modo de viver, ou, pelo menos, de enxergar a vida, pois vale lembrar que se está falando de um escritor cuja condição socioeconômica permitiu-lhe dedicar-se à poesia em tempo integral.

Mencionou-se anteriormente que a temática de sua construção verbal, ao contrário da grandiloquência que permeia de modo geral a poesia brasileira, preocupa-se com as miudezas, com os sapos, com os gravetos, com os passarinhos, com as formigas, com o rio e os peixes e as pedras. NO Livro das ignorãças, por exemplo, o "eu" poético destaca, no primeiro poema, a necessidade de "Desaprender oito horas por dia" (BARROS, 1998, p. 09) como condição para extrair das palavras e da vida sua essência.

Dessa forma, retomando o pensamento de Huizinga, mais uma vez nas palavras de Alice Áurea Penteado Martha, ao abordar a poesia para crianças e jovens, conclui que a poesia para crianças e jovens

(...) deve ser uma brincadeira a mais para os pequenos, um jogo que apresente recursos formais imprescindíveis como onomatopeias, rimas, repetições, paralelismos, contrassensos, jogos sonoros entre outros mais, podendo aprofundar seus recursos formais e temáticas quando dirigidas aos jovens.

Quanto à temática, não há nada definido; qualquer assunto pode ser de interesse de tais leitores, desde que lhes seja apresentado com clareza e

\footnotetext{
${ }^{44}$ HUIZINGA, Johan. Homo ludens: o jogo como elemento da cultura. São Paulo: Perspectiva, 1971.
} 
respeito ao seu desenvolvimento intelectual e emocional. O essencial é que as produções cativem seus leitores com o recurso à fantasia, por seu caráter de magia, pela valorização da sensação que os transporta do mundo real para o possível, construído pelas imagens e símbolos do poema. Desse modo, podem tratar de medos, perdas e ganhos, sentimentos diversos que contaminam o espírito do ser humano. (MARTHA, 2012, p. 47)

Defende-se, portanto, que a poesia de Manoel de Barros não só cativa seu leitor, instigando-o a (re)viver a relação ancestral, simbiótica, inexplicável, com a natureza, como também oferece-lhe a possibilidade de provar novamente daquela ingenuidade de outrora - no caso do leitor jovem ou adulto - ou, em se tratando do pequeno leitor, ampliar-Ihe o leque de opções de brincadeiras com as palavras, tocando seu mundo intuitivo, sensorial, naturalmente holístico.

Finalizando o embasamento teórico das análises a seguir, outro ponto relevante desta defesa diz respeito à potência da linguagem poética de Manoel de Barros, no sentido de arrebatar o leitor, ou seja, entende-se que sua poesia ou, mais especificamente, seu modo de construir o poema em ambas as obras acende no leitor

(...) o desejo de uma outra existência, mais livre e mais bela. E aproximando o sujeito do objeto, e o sujeito de si mesmo, o poema exerce a alta função de suprir o intervalo que isola os seres. Outro alvo não tem na mira a ação mais energética e mais ousada. A poesia traz, sob as espécies da figura e do som, aquela realidade pela qual, ou contra a qual, vale a pena lutar. (BOSI, 1977, p. 192)

Por se acreditar ser uma realidade pela qual vale a pena lutar, vale a pena encampar essa luta com Manoel de Barros, pela busca da palavra-brinquedo entre as ignorãças e o nada.

\subsection{1 - Poesia do (des)aprender}

Publicado originalmente na última década do Século XX (1993), O livro das ignorãças é dividido, do ponto de vista estrutural, em três partes: 1a) "Uma didática da invenção"; $2^{\mathrm{a}}$ ) "Os deslimites da palavra"; $3^{\mathrm{a}}$ ) "Mundo pequeno". Ainda no que concerne à estrutura, há uma assimetria tanto na concepção dos versos quanto das estrofes, bem como poemas compostos por apenas um verso dotado de lirismo, intensidade e beleza comparável aos haicais. 
As metáforas, os paradoxos e as sinestesias predominam nos traços poéticos, desenhando, em relação à temática, uma atmosfera exuberante marcada pela simplicidade, ternura, leveza e delicadeza, pelo desprendimento e claro, pela brincadeira. A abordagem poética da infância em Manoel de Barros oferece ao leitor possibilidades de remetê-lo a uma filosofia didático-poética de se viver.

O aspecto filosófico pode ser percebido já na epígrafe da primeira parte Uma didática da invenção -, por meio de uma frase, ou melhor, de um verso atribuído à figura de "Felisdônio". Segundo ele, "As coisas que não existem são mais bonitas." 45 . Afirmação arrebatadora, que desafia a percepção do leitor e o transporta para a atmosfera do imaginário. Afinal em que outro lugar o leitor poderia apreciar a beleza do que não existe?

Do ponto de vista do gênero, a estrutura do primeiro texto poético se aproxima mais de uma espécie de receita ou relação ou ainda lista de saberes necessários para se "apalpar as intimidades do mundo", fazendo com que a poeticidade resida justamente nas construções verbais paradoxais, no jogo de palavras inicialmente inconcebível denotativamente.

\section{Texto I}

Para apalpar as intimidades do mundo é preciso saber:

a) Que o esplendor da manhã não se abre com faca

b) O modo como as violetas preparam o dia para morrer

c) Por que é que as borboletas de tarjas vermelhas têm devoção por túmulos

d) Se o homem que toca de tarde sua existência num fagote, tem salvação

e) Que um rio que flui entre dois jacintos carrega mais ternura que um rio que flui entre dois lagartos

f) Como pegar na voz de um peixe

g) Qual o lado da noite que umedece primeiro.

etc

etc

etc

Desaprender oito horas por dia ensina os princípios. (BARROS, 1993, p. 09.)

Destaca-se, nesse poema-receita-relação, o último verso, em que o "eu" poético propõe ao leitor não apenas desaprender, mas "desaprender oito horas por

${ }^{45}$ BARROS, 1993, p. 07. 
dia", sinalizando que tal ato "ensina os princípios". Fica-se instigado a pensar que os princípios a serem ensinados residem apenas no campo do imaginário, o que conflui para o universo da intuição, da sensitividade, próprios da atmosfera infantil, o que torna o texto significativamente apetecível ao gosto da criança, visto que o "(...) imaginário, por sua vez, apesar de ter o componente racional, é constituído pelos aspectos lúdicos, oníricos, fantasiosos, afetivos, irracionais." (SCOFANO, 2018, p. 137).

Depois da proposta desenhada pelo "Texto I", o "eu" poético apresenta para o leitor poemas de caráter 'quase' didáticos, aparentemente vislumbrando um processo de (des)aprendizagem, ilustrado por meio de palavras que ao subverterem o seu sentido denotativo, desnudam-se e, parafraseando o próprio "eu" poético, "deliram", permitindo ao leitor o contato visceral com a palavra e, consequentemente, consigo mesmo, objetivando ilustrar nossas observações, apresentamos o "Texto VII":

\footnotetext{
No descomeço era o verbo.

Só depois é que veio o delírio do verbo.

O delírio do verbo estava no começo, lá onde a

criança diz: Eu escuto a cor dos passarinhos.

A criança não sabe que o verbo escutar não funciona

para cor, mas para som.

Então se a criança muda a função de um verbo, ele

delira.

E pois.

Em poesia que é voz de poeta, que é a voz de fazer nascimentos -

O verbo tem que pegar delírio. (BARROS, 1993, p. 15)
}

O "eu" poético de Manoel de Barros também ressalta no "Texto VII" a capacidade de (re)criação que reside na linguagem poética. Esse "fazer nascimentos" a que ele se refere nos últimos versos do poema se entrelaçam com a capacidade que a criança também possui de dar uma cor diferente à realidade a sua volta. Interessante pensar que, sob esse aspecto, a palavra, para se tornar poética, ou melhor, para delirar, tem que regressar a sua própria infância. Trata-se de uma experiência visceral, puramente sinestésica.

Encerrarem-se as considerações sobre a primeira parte da obra, analisandose o "Texto XIX" o qual representa o clímax do processo de (des)aprender da primeira parte, pois representa os caminhos percorridos pelo imaginário infantil para traduzir em palavras uma imagem, resultando numa linguagem com grau de 
poeticidade tamanho que a nomeação denotativa do objeto, além de frustrar as aspirações poéticas da linguagem infantil, traz opacidade ao que antes reluzia no imaginário do "eu" poético. É como se não houvesse espaço para a poesia na linguagem que se rendeu ao uso sistematizado, objetivo, puramente racional.

O rio que fazia uma volta atrás da nossa casa
era a imagem de um vidro mole que fazia uma volta atrás de casa.

Passou um homem e disse: Essa volta que o rio faz por trás de sua casa se chama enseada.

Não era mais a imagem de uma cobra de vidro que fazia uma volta atrás de casa.

Era uma enseada.

Acho que o nome empobreceu a imagem. (BARROS, 1993, p. 25)

O poema, ao ilustrar o efeito dessa dicotomia entre a linguagem poética e a não-poética e seus efeitos no imaginário infantil, mostra que a temática da poesia de Manoel de Barros, por privilegiar a incessante busca pela essência intuitiva, mítica, infante da palavra e por considerar a possibilidade de encontrá-la no universo infantil, cumpre o que há de mais ancestral na função da poesia: sua capacidade criadora. Como definira Antonio Cândido:

\begin{abstract}
Antes de conhecer as causas racionais dos fatos, o homem as imagina, as cria pela força da imaginação e as considera em seguida como realidades exteriores a ele. Poesia, neste sentido, é a criação a partir da fantasia, que é potente no primitivo como na criança, e que vai diminuindo à medida que se desenvolve a razão. Trata-se, portanto, de uma forma de ajustamento ao mundo, um modo especial de ver as coisas e o homem. A linguagem poética, eminentemente criadora, nasce da necessidade de exprimir, mas não sucede uma linguagem não-poética, eminentemente criadora, nasce da necessidade exprimir, mas não sucede a uma linguagem não-poética; pelo contrário, precede-a, tanto assim que o verso sempre surge antes da prosa. (CANDIDO, 2006, p. 146)
\end{abstract}

$\mathrm{Na}$ segunda parte da obra - Os deslimites da palavra - o poeta matogrossense valendo-se, segundo o texto "Explicação desnecessária", das anotações de um caderno de armazém feitas por um canoeiro que ficara três dias e três noites preso em sua canoa por causa da "maior enchente do Pantanal", passa a "desarrumar" as frases encontradas no final do caderno, frases que, segundo o autor, permitiram ao canoeiro "voar fora da asa". Segue o texto:

$\mathrm{Na}$ enchente de 22, a maior de todas as enchentes do Pantanal, canoeiro Apuleio vagou três dias e três noites por cima das águas, sem comer, sem dormir - e teve um delírio frásico. A estórea aconteceu que um dia 
remexendo papeis na Biblioteca do Centro de Criadores da Nhecolândia, em Corumbá, dei com um pequeno Caderno de Armazém, onde se anotavam compras fiadas de arroz feijão fumo etc. Nas últimas folhas do caderno achei frases soltas, cerca de 200 . Levei o manuscrito para casa. Lendo as frases com vagar imaginei o desolo a fraqueza e o medo talvez tenham provocado, no canoeiro, uma ruptura com a normalidade. Passei anos penteando e desarrumando as frases. Desarrumei o melhor que pude. $\mathrm{O}$ resultado ficou esse. Desconfio que, nesse caderno, o canoeiro voou fora da asa. (BARROS, 1993, p. 31)

Interessante pensar que a não necessidade da explicação tem muito a ver com o processo de (des)aprender proposto neste subcapítulo, uma vez que a transgressão dos sentidos objetivos, puramente racionais dão o tom da obra. Não se pode esquecer que se trata $\mathrm{d} O$ livro das ignorãças.

Entende-se assim que a "ignorãça" a que o poeta se refere relaciona-se de modo muito mais profundo com o desconhecimento ou a não valorização da potência da linguagem poética em si, do que com a utilização da linguagem de forma sistematizada. Embora Manoel de Barros domine todos os mecanismos gramaticais e linguísticos do idioma, ele prefere a transgressão à obediência - daí a opção pelos deslimites da palavra.

Entretanto o "eu" poético não deixa de reconhecer a força das "algemas" que o prendem, seja em relação à língua, seja em relação à vida, como se pode observar no poema a seguir, mais especificamente no último verso:

Ando muito completo de vazios.

Meu órgão de morrer me predomina.

Estou sem eternidades.

Não posso mais saber quando amanheço ontem.

Está rengo de mim o amanhecer.

Ouço o tamanho oblíquo de uma folha.

Atrás do ocaso fervem os insetos.

Enfiei o que pude dentro de um grilo o meu destino.

Essas coisas me mudam para cisco.

A minha independência tem algemas. (BARROS, 1993, p. 55)

Chega-se à terceira parte do livro - Mundo pequeno - com o "eu" poético se dirigindo ao sagrado, falando de sua casa ao redor da natureza e das reminiscências de sua infância - o menino e suas latas -, ressaltando seu estado de comunhão com a natureza.

Além do estado de comunhão com a natureza, destaca-se também o último verso - "De tarde um velho tocará sua flauta para inverter os ocasos.". Por meio dele, entende-se que a abordagem de Manoel de Barros metaforiza questões cujo 
objetivo é mostrar ao leitor que a "(...) consciência, quando amadurece e se aguça, chega à encruzilhada: ou à morte da arte, ou à reimersão no mundo-da-vida que, como a infância, se renova a cada geração." (BOSI, 1977, p. 158). Nesse cenário, poesia e infância são fulcrais para a vida.

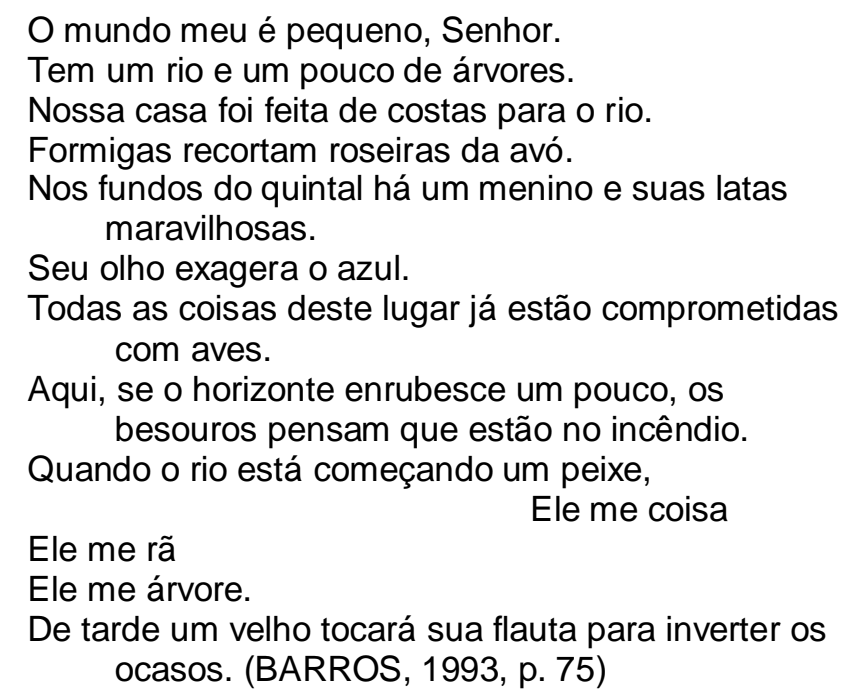

As reminiscências da infância também dão o tom no último poema contemplado nesta análise referente aO livro das ignorãças. Nele o "eu" poético desenha uma temática de cunho autobiográfico de Manoel de Barros. Nesse sentido, a fantasia do texto reside na inserção do leitor no cenário escolar - tão familiar à criança quanto a relação professor/aluno. Outro detalhe interessante diz respeito à ternura e, sobretudo, à cumplicidade na postura do professor.

É significativo abordar essas questões porque não são comuns na obra de Manoel de Barros cenários que extrapolem o quintal, ou mesmo o Pantanal matogrossense. Todavia, mesmo fora do cenário típico de sua literatura, elementos que ligam à natureza são evocados.

Entende-se assim que da confluência desses elementos brota a fantasia no imaginário do leitor, uma vez que os arquétipos utilizados pelo "eu" poético possuem significado emblemático no cenário social: a escola, o professor e principalmente o desejo de transgredir a o sentido das palavras subjacente à criança.

Sob esse aspecto, defende-se que o contato entre as imagens propostas pelo "eu" poético e a imaginação do leitor não "(...) explica nem tenta entender o objeto e apenas usufrui do encontro por meio da recuperação de uma ingenuidade e simplicidade perdidas que são a sabedoria de ver as coisas no frescor de sua 
primeira vez. É a experiência da adesão total à imagem como epifania. Não precisa do saber." (SCOFANO, 2018, p. 90-91).

Destacam-se ainda os versos que abarcam a fala do professor, que também é padre, - lembrando que, na história educacional do Brasil, é extremamente comum a junção desses dois termos. O que talvez não fosse tão comum é a amabilidade presente em seu discurso, dotada de empatia e tolerância, evocando não apenas a ascendência bugre do "eu" poético, como também lembrando a ele que é nos "desvios" da estrada que se encontram os araticuns maduros, numa explícita valorização das raízes indígenas.

Defende-se assim que no poema Manoel de Barros condensa a valorização de se transgredir a racionalidade gramatical da palavra, da ascendência bugre que, de certa forma, pertence a todos os brasileiros, e a harmonia, cumplicidade e amizade na relação entre professor e aluno, atribuindo poeticidade ao ato de (des)aprender. Segue o poema:

Descobri aos 13 anos que o que me dava prazer nas leituras não era a beleza das frases, mas a doença delas.

Comuniquei ao Padre Ezequiel, um meu preceptor, esse gosto esquisito.

Eu pensava que fosse um sujeito escaleno.

- Gostar de fazer defeitos na frase é muito saudável, o Padre me disse.

Ele fez um limpamento em meus receios.

O Padre falou ainda: Manoel, isso não é doença, pode muito que você carregue para o resto da

E se riu. vida um certo gosto por nadas...

Você não é de bugre? - ele continuou.

Que sim, eu respondi.

Veja que bugre só pega por desvios, não anda em estradas -

Pois é nos desvios que encontra as melhores surpresas e os araticuns maduros.

Há que apenas saber errar bem o seu idioma.

Esse padre Ezequiel foi o meu primeiro professor de agramática. (BARROS, 1993, p. 87)

\subsection{2 - O nada e suas transbordâncias}

Houve um tempo em que os poetas foram considerados perigosos, representavam ameaça à ordem social estabelecida, isso porque eram acusados, entre outros fatores, de suscitar sensibilidade e percepção tamanhas no leitor que 
este se tornava capaz de refletir profundamente acerca da sociedade a sua volta. Daí o entendimento de Platão de que era fundamental expulsá-los da república para que houvesse ordem, harmonia, subserviência e passividade.

$\mathrm{Na}$ contemporaneidade, infelizmente, esse não é mais o posto ocupado pelos poetas, tampouco por suas poesias; eles já não oferecem perigo à ordem social, tampouco são considerados uma ameaça. Isso porque, desde o século XIX, quando Baudelaire sinalizara que a poesia não tem outro fim senão ela mesma, abordar a relação entre o nada e a poesia não necessariamente constitui algo novo.

No entanto, quando se fala de literatura infantil e juvenil, por se tratar de um leitor em formação - evidentemente que se acredita também que o mesmo conceito pode ser tomado no caso de adultos que não tenham tido, ao longo de sua vida, contato com o texto literário - toda obra, em prosa ou poesia, deve ser apresentada ao leitor de modo "(...) que lhe permita compreender melhor o homem e o mundo, para nelas descobrir uma beleza que enriqueça sua existência; ao fazê-lo, ele compreende melhor a si mesmo." (TODOROV, 2010, p. 33).

Dessa forma, neste subcapítulo, defende-se que Manoel de Barros, em sua obra Livro sobre Nada, trata como "nada" as sutilezas da vida que, delicadas e belas, muitas vezes em sua maioria passam despercebidas, mas, quando são tocadas pelo olhar infantil, têm sua significação potencializada, a ponto de ativar o imaginário do leitor, visto que este, como já mencionado nesta tese, é constituído mais pelos aspectos ligados à fantasia e emoção do que à razão.

O olhar infantil a que se fez referência pertence ao "eu" poético de Manoel de Barros, cuja capacidade estética de desenhar imagens poéticas sob uma perspectiva que prima em defender há uma "desutilidade poética" nas coisas. Por outro lado, que essa mesma "desutilidade poética" é fundamental para dar cor, poesia, beleza à vida.

Publicado originalmente em 1996, do ponto de vista da estrutura, o Livro sobre Nada é dividido em quatro partes: $\left.1^{\underline{a}}\right)$ "Arte de infantilizar formigas"; $2^{\mathrm{a}}$ ) "Desejar ser"; 3ㄹ) "O livro sobre nada"; 4a) "Os Outros: o melhor de mim sou Eles".

Contudo vamos iniciar as observações pelo texto inicial "Pretexto". Nele quem se dirige ao leitor ainda é o autor e não o "eu" poético, e Manoel de Barros explicita suas intenções, sinalizando para o leitor um esvaziamento das percepções. 
(...) o nada de meu livro é nada mesmo. É coisa nenhuma por escrito: um alarme para o silêncio, um abridor de amanhecer, [...]. O que eu queria era fazer brinquedos com as palavras. Fazer coisas desúteis. O nada mesmo. Tudo que use o abandono por dentro e por fora. (BARROS, 2001, p. 07)

É conhecida a velha máxima filosófica: "Não se pode encher um copo que está cheio", daí se entender o desejo do autor de utilizar o "abandono por dentro e por fora", pois, por algum motivo que escapa à medida que o ser humano se torna adulto, perde a capacidade de esvaziar-se a si mesmo. Nesse aspecto, cheio que está, não ousa, ao contrário das crianças, transbordar suas percepções, seus sentimentos, ou seja, a poesia que reside em si, tantas vezes sufocada.

Na primeira parte da obra "Arte de infantilizar formigas" o leitor é convidado a caminhar sobre uma linha tênue, quase entre a lucidez e a loucura, sendo a última, acompanhada do desejo de brincar com as palavras, condições fundamentais sem as quais se torna impossível extrair o poético das coisas, que reside no fundo dos quintais do imaginário, onde é preciso resgatar o adormecido "dessaber":

As coisas tinham para nós uma desutilidade poética. Nos fundos do quintal era muito riquíssimo o nosso dessaber. A gente inventou um truque pra fabricar brinquedos com palavras. $\mathrm{O}$ truque era só virar bocó.

Como dizer: Eu pendurei um bentevi no sol... (BARROS, 2001, p. 11)

Brincar com as palavras, "virar bocó". Eis o que é proposto pelo "eu" poético no primeiro poema da obra. Esse é o truque, o segredo para se gozar da poeticidade das coisas. Mas para isso precisa-se infantilizar o olhar, daí o desafio: só alcança a infância da palavra quem possui a infância no olhar, e só possui a infância no olhar quem a possui na alma.

É possível que, para o leitor adulto, seja muito complexo estabelecer tal relação com o texto poético de Manoel de Barros, talvez por soar meio constrangedor "virar bocó", atitude normal, até divertida, para o universo infantil, ou talvez por haver alguma nostalgia nesse processo, aparentemente sentida pelo "eu" poético, porque ilustrada pelo poema abaixo, composto por apenas um verso:

$$
\text { O menino de ontem me plange. (BARROS, 2001, p. 19) }
$$

Apesar do planger do menino de ontem, o "eu" poético segue brincando com as palavras nas reminiscências de sua meninice. Destacam-se nesse ponto os 
excertos extraídos do "Diário de Bugrinha"46". Trata-se de poemas curtos, todos com apenas uma estrofe, oscilando entre um e quatro versos, no máximo. Todos eles abordando a constante brincadeira com as palavras e o quanto tal brincadeira pode proporcionar tamanha comunhão poética com a natureza, capaz de ser percebida sinestesicamente pelo leitor. Seguem três exemplos:

Eu queria crescer pra passarinho... (BARROS, 2001, p. 30)

Sem chuvas, já reparei, as andorinhas perdem o poder de voar livres. (BARROS, 2001, p. 31)

Hoje completei 10 anos. Fabriquei um brinquedo com palavras. Minha mãe gostou. É assim:

De noite o silêncio estica os lírios. (BARROS, 2001, p. 33)

Caminha-se para as considerações a respeito da segunda parte da obra Desejar ser -, considerando a epígrafe inicial em que Manoel de Barros recorre ao Padre Antônio Vieira - paixão antiga do poeta, citado em outras obras e já abordado nesta tese - entretanto, dessa vez o poeta explicita o diálogo poético.

Pode-se inferir tal afirmação pela aproximação temática entre o título da segunda parte e os dizeres da epígrafe.

O maior apetite do homem é
desejar ser. Se os olhos veem
com amor o que não é, tem ser

Padre Antônio Vieira em PAIXÕES HUMANAS.

A partir da epígrafe sucede um conjunto de poemas em que o "eu" poético dialoga, ora com o sagrado, ora com outros personagens da história da Arte, como Beethoven e Charles Chaplin, e, na maioria das vezes com sua própria alteridade. Independentemente do diálogo proposto, é perceptível, tanto pela temática quanto

\footnotetext{
46 Precisa-se esclarecer que, embora o termo "bugre" tenha adquirido conotação pejorativa na contemporaneidade, ele é empregado de modo recorrente na obra do poeta mato-grossense no sentido de "índio sem aldeia". O próprio "eu" poético de Manoel de Barros elucida isso para o leitor na obra Memórias inventadas: As infâncias de Manoel de Barros (edição de 2008), mais especificamente no texto "Gramática do povo Guató" (páginas 90-91), ao se referir ao personagem do índio Rogaciano.
} 
pela estrutura - uso recorrente da primeira pessoa, por exemplo - a ideia inicial proposta pelo subtítulo e sua epígrafe, ou seja, para o "eu” poético só uma coisa importa: "desejar ser".

Para atingir tal objetivo, o "eu" poético elucida que escreve com linguagem própria:

\begin{abstract}
Escrevo o idioleto manoelês archaico' (Idioleto é o dialeto que os idiotas usam para falar com as paredes e com as moscas). Preciso de atrapalhar as significâncias. O despropósito é mais saudável do que o solene. (Para limpar das palavras alguma solenidade - uso bosta.) sou muito higiênico. E pois. O que ponho de cerebral nos meus escritos é apenas uma vigilância para não cair na tentação de me achar menos tolo que os outros. Sou bem conceituado para parvo. Disso forneço certidão.
\end{abstract}

'Falar em archaico: aprecio uma desviação ortográfica para o archaico. Estâmago por estômago. Celeusma por celeuma. Seja este um gosto que vem detrás. Das minhas memórias fósseis. Ouvir estâmago produz uma ressonância atávica dentro de mim. Coisa que sonha de retravés. (BARROS, 2001, p. 43)

Escolheu-se o poema acima porque nele se pode perceber tanto o "eu" poético quanto o autor se referindo ao leitor e, em ambos os casos, é manifestado o desejo de brincar com as palavras, revelando que, para Manoel de Barros, buscar na infância das palavras a poeticidade da vida não é apenas um projeto estético, trata-se de um projeto de existência humana.

Finalizando as observações sobre a segunda parte da obra, destacam-se dois aspectos fortemente presentes na estética verbal e na temática do Livro sobre Nada. O primeiro diz respeito à supremacia da natureza sobre o conhecimento científico, metaforizando a relação entre o eterno e o efêmero, ou mesmo o sagrado e o profano, ou ainda, a poesia e a ciência.

A ciência pode classificar e nomear os órgãos de um sabiá mas não pode medir seus encantos.

A ciência não pode calcular quantos cavalos de força existem nos encantos de um sabiá.

Quem acumula muita informação perde o condão de adivinhar: divinare.

Os sabiás divinam. (BARROS, 2001, p. 53) 
O segundo aspecto evidencia a importância do nada, ou melhor, a riqueza poética que eclode a partir da ideia do nada, já introduzindo o leitor na terceira parte da obra, uma vez que já se faz referência ao último poema da segunda parte.

O que não sei fazer desmancho em frases.

Eu fiz o nada aparecer.

(Represente que o homem é um poço escuro.

Aqui de cima não se vê nada.

Mas quando se chega ao fundo do poço já se pode ver o nada.)

Perder o nada é um empobrecimento. (BARROS, 2001, p. 63)

A terceira parte da obra - O livro sobre nada - é breve e intensa como os poemas que a compõem, todos formados por estrofes de, no máximo, três versos, muito apetecíveis ao gosto da criança em sua fase inicial de leitura. Contudo é preciso ressaltar que, mesmo breves, são poemas dotados de grande intensidade, formados por um misto de paradoxos e sinestesias.

As inúmeras temáticas remetem a uma experiência poética cuja complexidade de compreensão lógica e beleza são equivalentes, aguçando a percepção no imaginário do leitor a percepção, por meio da sofisticação de uma construção poética que privilegia o caráter lúdico das palavras, tornando-as lampejos de poeticidade, como num espetáculo pirotécnico, seguem alguns exemplos:

É mais fácil fazer da tolice um regalo do que da sensatez. (BARROS, 2001, p. 67)

Tudo que não invento é falso. (BARROS, 2001, p. 67)

O que sustenta a encantação de um verso (além do ritmo) é o ilogismo. (BARROS, 2001, p. 68)

A terapia literária consiste em desarrumar a linguagem a ponto que ela expresse nossos mais fundos desejos. (BARROS, 2001, p. 70) 
O artista é um erro da natureza. Beethoven foi um erro perfeito. (BARROS, 2001, p. 70)

Palavra poética tem que chegar ao grau de brinquedo para ser séria. (BARROS, 2001, p. 71)

Defende-se que os poemas dessa terceira parte são concebidos para despertar no leitor a compreensão pela beleza, não pela lógica. Não se quer dizer com tal afirmação que eles são incompreensíveis, mas que não foram feitos para serem explicados, dialogando com a afirmação de Octavio Paz: "O poema é inexplicável, não ininteligível" (PAZ, 2012, p. 311).

Acredita-se ainda que, além de a compreensão por meio da beleza constituir característica imanente ao texto poético, no caso da poesia de Manoel de Barros, ela também se dá pela ludicidade e, no caso do Livro sobre Nada, pelo transbordar de sensações, provocado pela composição sinestésica dos versos, a ponto de permitir ao leitor tocar a essência de seu próprio ser, expressando seus mais profundos desejos, como afirma o "eu" poético "A terapia literária consiste em desarrumar a linguagem / a ponto que ela expresse nossos mais fundos desejos." (BARROS, 2001, p. 70).

Caminha-se então para a quarta parte da obra - Os outros: o melhor de mim sou Eles - cujo título pode instigar o leitor a uma experiência de alteridade, experiência esta que, via de regra, é natural no universo infantil, pois demanda empatia, colocar-se no lugar do outro, atitudes que crianças demonstram com naturalidade e que, no caso dos adultos, não raro exigem enorme esforço.

Afinal, como se disse anteriormente, é impossível encher um copo que já está cheio, e, para que se possa transbordar poeticamente, o ser humano precisa primeiro esvaziar-se de todo pretenso conhecimento que possui acerca da linguagem, para poder experimentá-la, compreendê-la, senti-la em sua infância, pois

Entre o grito e o calar, entre o significado que é todos os significados e a ausência de significação, o poema se levanta. O que diz esse esguio jogo de palavras? Diz que não diz nada que já não tenham dito o silêncio e a gritaria. E, ao dizê-lo, o ruído e o silencia cessam. Vitória precária, sempre ameaçada pelas palavras que não dizem nada, pelo silêncio que diz: nada. (PAZ, 2012, p. 315) 
Dessa forma, escolhe-se um poema que vem acompanhado de uma nota. Mais uma vez, autor e "eu" poético se confundem no interior da obra, intuindo guiar, instruir o leitor, explicitando-lhe informações apresentadas no poema.

Nota: Um tempo antes de conhecer Picasso, eu tinha visto na aldeia boliviana de Chiquitos, perto de Corumbá, uma pintura meio primitiva de Rômulo Quiroga. Era um artista iluminado e um ser obscuro. Ele mesmo inventava as suas tintas. Trazia dos cerrados: seiva de casca de angico (era o seu vermelho); caldos de lagartas (era o seu verde); polpa de jatobá maduro 9era o seu amarelo). Usava pocas de piranhas derretidas para dar liga aos seus pigmentos. Pintava sobre sacos de aniagem. Mostrou-me um ancião de cara verde que havia pintado. Eu disse: mas verde não é a cor da esperança? Como pode estar em rosto de ancião? A minha cor é psíquica, ele disse. $E$ as formas incorporantes. Lembrei que Picasso depois de ver as formas bisônticas da África, rompeu com as formas naturais, com os efeitos de luz natural, com os conceitos de espaço e de perspectiva, etc etc. $E$ depois quebrou planos, ao lado de Braque, propôs a simultaneidade das visões, a cor psíquica e as formas incorporantes. Agora penso em Rômulo Quiroga. Ele foi apenas e uma só paz na terra. Mas eu vi latejar rudemente nos seus traços milagres de Klee. Salvo não seja. (BARROS, 2001, p. 74)

\section{As lições de R. Q.}

Aprendi com Rômulo Quiroga (um pintor boliviano):

A expressão reta não sonha.

Não use o traço acostumado.

(...)

Arte não tem pensa:

O olho vê, a lembrança revê, e a imaginação transvê.

É preciso transver o mundo.

Isto seja:

Deus deu a forma. Os artistas desformam.

É preciso desformar o mundo:

Tirar da natureza as naturalidades.

Fazer cavalo verde, por exemplo.

Fazer noiva camponesa voar - como em Chagall.

(...) (BARROS, 2001, p. 75)

Chega-se ao final das considerações acerca do Livro sobre Nada - e também do segundo capítulo desta tese - defendendo-se que a poesia de Manoel de Barros instiga seu leitor a olhar o mundo com os olhos da imaginação - tão próprio da criança -, a fim de transvê-lo; defende-se também que, ao infantilizar seu olhar, o leitor aguça suas percepções acerca da vida, de si mesmo.

Considera-se ainda que seu projeto estético de transgredir a lógica, subvertendo o sentido puramente denotativo das palavras, sistêmico da linguagem dialoga profundamente com o modo de a criança ler o mundo, daí sua literatura ser 
apetecível ao gosto do pequeno e do jovem leitor, por atender às percepções intuitivas que compõem seu imaginário.

Quanto ao leitor adulto, entendendo e coadunando com a posição de Tzvetan Todorov, ao afirmar que a "(...) literatura faz viver experiências singulares." (TODOROV, 2010, P. 77), defende-se a poesia de Manoel de Barros como instrumento que resgata situações e elementos subjacentes capazes de estabelecer diálogo com uma gama de infâncias que residem no cerne da constituição do imaginário cultural, pois evoca não só a ascendência indígena, como também a relação profunda, ainda que intuitiva, com a natureza.

Enfim conclui-se que a estética da poesia de Manoel de Barros, por meio dessa constante busca pela infância da palavra intui alimentar o imaginário do leitor a fim de fazê-lo (re)viver sua ancestralidade, inserindo, por um lado, a criança ainda mais em sua atmosfera lúdica, no espaço do imaginário pertencente só a ela, e, por outro lado, transportando o adulto não só para o quintal que reside no seu imaginário, no espaço de sua infância, mas, sobretudo, no quintal de si mesmo, pois só através de uma experiência estética dessa magnitude, torna-se possível "transver o mundo". 
Figuras 3 e 4: Cora Coralina e Manoel de Barros.

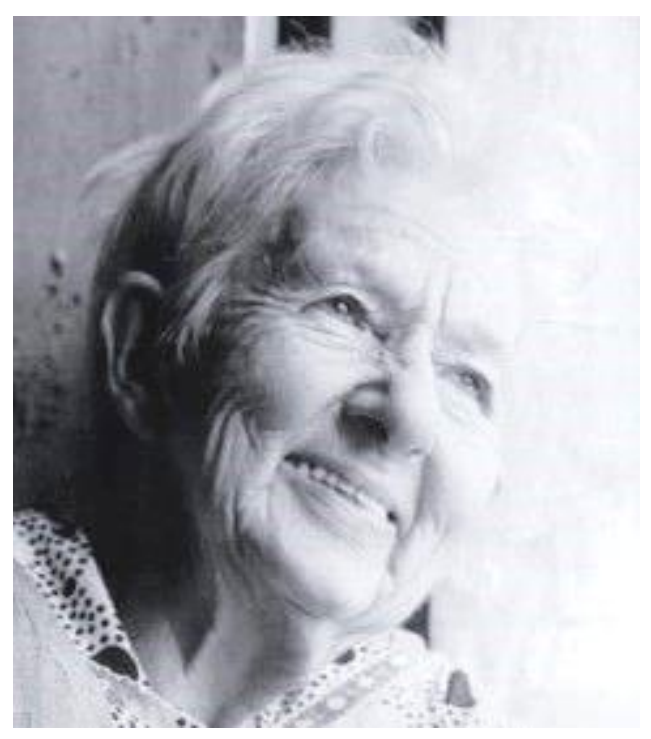

\section{Cora Coralina e Manoel de Barros: alguns diálogos}

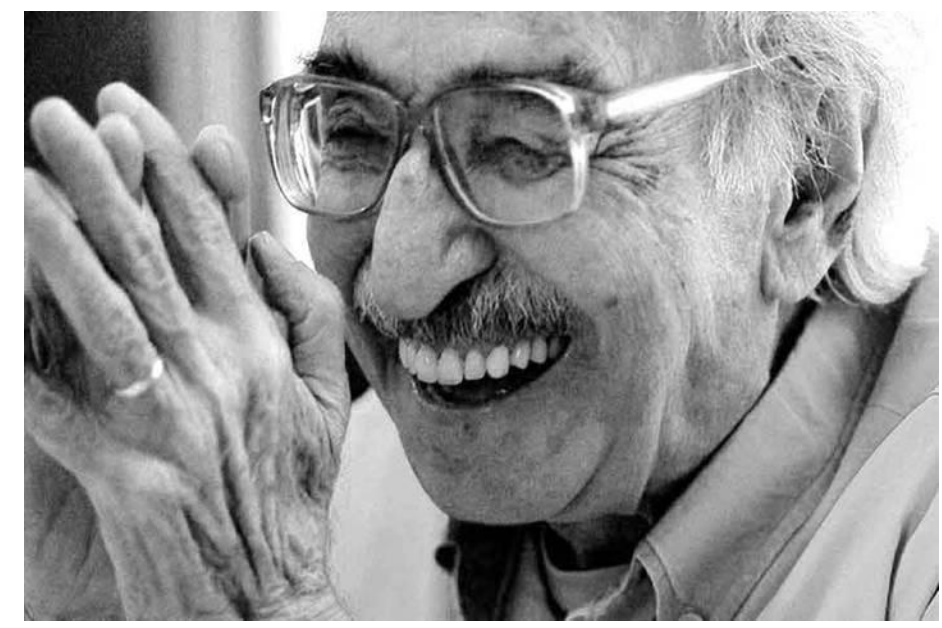

Fontes: Respectivamente, http://histormundi.blogspot.com/2018/01/a-velhice-na-visao-decora-coralina.html e https://www12.senado.leg.br/radio/1/reportagem-especial/meninocentenario-poeta-manoel-de-barros, ambas acessadas no dia 19/11/2019. 


\section{CAPÍTULO III: COZINHA E QUINTAL: LETRAS DA ESCRIVANINHA}

“(...) a totalidade nos acalenta, somos um sinal que alguém faz a alguém, somos o canal de transmissão: por nós fluem as linguagens e nosso corpo as traduz em outras linguagens. As portas se abrem de par em par: 0 homem regressa. O universo de símbolos é também um universo sensível. O bosque das significações é o lugar da reconciliação.

Octavio Paz, in O Arco e a Lira. São Paulo: Cosac Naify, páginas 337-338, 2012.

Em um país de dimensões continentais, seria ingênuo pensar que a diversidade de sua gente, sua história, cultura, arte e literatura também não possuam dimensões continentais. Experimentam-se cotidianamente e às vezes com perplexidade grandes mudanças no Brasil, mudanças essas que se manifestam em várias facetas que compõem a sociedade brasileira, sendo que as mais arrojadas muitas vezes surgem do campo da arte.

Contudo, quando se trata do processo que concebeu a educação formal no país, nem sempre tamanha riqueza étnico-cultural fora reconhecida. Mesmo a literatura apontando metafórica e esteticamente o processo de miscigenação sob o qual essa gente se fez, por meio de movimentos como, por exemplo, o indianismo romântico ainda no início do século XIX, privilegiou-se a raiz lusitana na construção do tecido social e identitário do Brasil, em relação às igualmente importantes raízes nativas e africanas.

De modo geral, tais circunstâncias alimentaram em uma sociedade onde frequentar escolas era privilégio de poucos, valores caros a apenas uma das culturas que compõem nossa miscelânea cultural e identitária, desenvolvendo, intuitivamente ou não, um pensamento clichê que tende a hierarquizar, erroneamente, a composição histórico-cultural do Brasil, potencializando a relevância de um povo em detrimento de outros.

Mesmo hoje, testemunha-se em vários campos da sociedade essa potencialização. Não é incomum verificar nichos sociais de caráter político, religioso, até mesmo artístico, protagonizando circunstâncias que ferem questões - como o laicismo, por exemplo - fundamentais para a manutenção do próprio Estado 
Democrático de Direito, em nome de um pensamento aristocrático, retrógrado, colonial.

No campo educacional, infelizmente, não tem sido diferente. Abordar questões relacionadas à pluralidade, em todas as suas especificidades, principalmente procurando evidenciar quão positiva fora a contribuição dessas para a composição do tecido histórico, cultural e identitário é constantemente um desafio.

Tal fenômeno levou, durante muito tempo, a um complexo processo de obliteração no que concerne ao reconhecimento representativo das minorias na constituição da sociedade brasileira, pois “(...) quando uma identidade étnica hiperinvestida oblitera todas as outras identidades de classe, ela deixa de ser uma ferramenta ou uma caixa de ferramentas; ela se torna (...) uma camisa de força." (DEVEREUX, 1972, p. 162-163, apud CUCHE, 1999, p. 191).

No caso da literatura infantil não foi diferente, em se tratando da educação e da formação de leitores “(...), do final do século XIX até o surgimento de Monteiro Lobato, os paradigmas vigentes eram o nacionalismo, o intelectualismo, o tradicionalismo cultural (...) e o moralismo religioso (...) em conformidade com os preceitos cristãos." (GREGORIN FILHO, 2009, p. 28).

Esse processo de obliteração cultural, potencializado pelo fato de se enxergar crianças como "adultos em miniatura" até o final do século XIX - quiçá até o início do século $X X$-, fomentou a proliferação de obras cujas temáticas, em sua maioria, possuíam características fortemente religiosas e tom moralizador, como, por exemplo, O coração de Edmundo de Amicis, já mencionado no início desta pesquisa, e Cazuza de Viriato Correa.

Além das obras supracitadas, outro lançamento que merece destaque foi 0 livro Saudade de Tales de Andrade, pois a partir dele, "(...) revela-se um cenário que vai ser um dos mais trilhados pela literatura infantil daí em diante; o rural." (GREGORIN FILHO, 2009, p. 25). O destaque se deve ao fato de que o cenário rural também está presente na obra de Cora Coralina, todavia com especificidades que serão abordadas mais adiante.

Já em relação à linguagem poética privilegiaram-se, durante muito tempo, aspectos estruturais e temáticas moralizantes, em que predominava certo didatismo. Nomes como o de Olavo Bilac transmitiam, ainda que por versos rimados, estrofes cadenciadas e linguagem rebuscada, uma mensagem que dialogava muito pouco 
com a fantasia e com o universo infantil. A estética do poema parecia apenas cumprir a função de parecer mais "apetecível” ao que se entendia por gosto infantil.

Outrossim, mesmo a partir do surgimento do Sítio do pica-pau amarelo de Monteiro Lobato - com personagens muito mais próximos do universo infantil do que os concebidos até então, e uma temática que valoriza a pluralidade cultural do Brasil - nossa sociedade continuou caminhando a passos lentos no que concerne ao reconhecimento do valor de raízes nativas e africanas na constituição da essência étnico-cultural brasileira. Apenas no final do século $X X$, início do século $X X I$, criou-se a lei $11.645^{47}$, que garantia a obrigatoriedade de se abordar temas relacionados com "História e cultura afro-brasileira e indígena".

Colocadas tais questões e tendo claro que a literatura "(...) é a expressão máxima da arte e da alma de um povo" (GREGORIN FILHO, 2009, p. 75), defendese que as obras de Cora Coralina e Manoel de Barros evocam elementos cuja representação cultural e identitária remete o leitor a um Brasil simultaneamente próximo e distante.

Próximo porque ambos apresentam questões que levam o leitor a um contato profundo, visceral, intrínseco com a natureza em suas várias metamorfoses - o que transcende o contexto geográfico em que o leitor está inserido, já que lhe proporciona dialogar com uma ou outra forma. A natureza em Cora Coralina e Manoel de Barros ora é desenhada em seu estado bruto, como em Menino do Mato, ora em seu estado agrícola, como em Poema do Milho, ora ainda em seu estado extraordinário, como em Os meninos verdes e Memórias inventadas.

Distante porque ambos suscitam costumes e brincadeiras que para as crianças do século XXI, especialmente as que vivem imersas num contexto puramente urbano e digital, soam como ecos de outrora, algo que talvez já tenham ouvido falar, do tempo de seus pais ou avós, mas que não conseguem conceber, como sentar para ouvir as histórias de sua bisavó ou mesmo avó, como em O Prato Azul-Pombinho, ou ainda brincar com latas como em O livro das ignorãças.

Na mesma linha, o pensamento de Denys Cuche:

A identidade social de um indivíduo se caracteriza pelo conjunto de suas vinculações em um sistema social: vinculação a uma classe sexual, a uma

\footnotetext{
${ }^{47}$ A Lei $11.645 / 2008$ altera a Lei $9.394 / 1996$, modificada pela Lei $10.639 / 2003$, a qual estabelece as diretrizes e bases da educação nacional, para incluir no currículo oficial da rede de ensino a obrigatoriedade da temática "História e cultura afro-brasileira e indígena".
} 
classe de idade, a uma classe social, a uma nação, etc. A identidade permite que o indivíduo se localize em um sistema social e seja localizado socialmente. (CUCHE, 1999, p. 177)

Intenta-se que, independentemente do grau de proximidade proporcionado ao leitor, Cora Coralina e Manoel de Barros, valendo-se da potência da palavra poética, recorrem a elementos, circunstâncias, costumes capazes de dialogar com traços que, embora pareçam figurar na periferia do cenário nacional contemporâneo, residem no centro das mais profundas entranhas da alma brasileira, como será demonstrado ao longo deste capítulo.

E como crianças nas casas dos avós, a poesia de ambos convida o leitor a se deliciar na cozinha poética de Cora Coralina, para depois brincar no igualmente poético quintal de Manoel de Barros, num cenário terno, mágico, de contato profundo com a terra, metaforizando uma infância bucólica familiar aos interiores do Brasil.

Nas palavras de Nelly Novaes Coelho, como “(...) é natural na criança, o predomínio dos sentidos sobre a razão" (1982, p. 148), fazendo com que ela reaja "basicamente pelos instintos, sentidos, sentimentos ou emoções" (1982, p. 148) tais aspectos potencializam ainda mais a poeticidade da cozinha e do quintal. Isso porque é a palavra poética que desperta o imaginário para reviver o fantástico, pois feita "(...) de matéria inflamável, as palavras ardem no instante em que são tocadas pela imaginação ou pela fantasia" (Paz, 2012, p. 43).

Ademais, referindo-se ao processo de formação da criança, do jovem ou mesmo do adulto por meio do texto literário, mais especificamente do texto poético, opta-se por valorizar uma abordagem cujo caráter pedagógico não se sobreponha ao artístico. Não se quer dizer com tal afirmação que Pedagogia e Arte não possam e ou não devam dialogar: acredita-se inclusive ser fundamental tal relação.

Nesse cenário, tanto as literaturas infantil e juvenil quanto pesquisas acerca delas, tornam-se cada vez mais relevantes, dada a importância de se proporcionar experiência poética às crianças e aos jovens oferecendo-Ihes poesia, enquanto se tenta compreender melhor o universo maravilhoso que os envolve.

Daí ser tão importante compreender que crianças e jovens, assim como a palavra poética, fazem enxergar o mundo de modo mais intuitivo do que conceitual, fundindo "os sonhos e a vida prática, o imaginário e o real, os ideais e sua possível/impossível realização" (Coelho, 1982, p. 27), por meio de imagens que 
resultam de "um complicado processo de organização perceptiva que se desenvolve desde a primeira infância" (Bosi, 1977, p. 15).

Em se tratando das obras de Cora Coralina e Manoel de Barros, entende-se haver a presença do caráter universal e atemporal próprios da linguagem poética, e por que não dizer da Arte. Embora marcadas fortemente pelo regionalismo, valemse, dentre outros, do apontamento de Alfredo Bosi ao afirmar que a instância poética

(...) parece tirar do passado e da memória o direito à existência; não de um passado cronológico puro - o dos tempos já mortos -, mas de um passado presente cujas dimensões míticas se atualizam no modo de ser infância e do inconsciente. (1977, p. 112)

Ainda é preciso considerar, além dos elementos inerentes ao texto poético, os que são fundamentais para o processo de formação cultural e identitária do indivíduo, desde a primeira idade. Observe-se, em última instância, coadunamos com o pensamento de Denys Cuche no que concerne à relação entre cultura e identidade:

(...) a cultura pode existir sem consciência de identidade, ao passo que as estratégias de identidade podem manipular e até modificar uma cultura que não terá então quase nada em comum com o que ela era anteriormente. A cultura depende em grande parte de processos inconscientes. A identidade remete a uma norma de vinculação, necessariamente consciente, baseada em oposições simbólicas. (CUCHE, 1999, p. 176)

Colocadas tais questões, este capítulo fora subdividido em três subcapítulos, com o intuito de elucidar aspectos das obras dos autores que são considerados fundamentais nesta tese, evidenciando a importância de ambas as obras na composição do cenário da literatura infantil e juvenil no país.

No primeiro subcapítulo abordam-se questões ligadas à "simplicidade" presente na obra de Cora Coralina e Manoel de Barros, simplicidade essa relacionada tanto à estrutura - construída majoritariamente por versos livres quanto ao trabalho com a linguagem - privilegiando léxico acessível e sintaxe com baixo grau de complexidade, compreensível para a criança -, e, não menos importante, com o modo de enxergar o universo infantil presente em ambos.

Ressalta-se ainda que o elemento "simplicidade", que está sendo proposto no subcapítulo, foi inspirado nos conceitos propostos por Ítalo Calvino, em sua obra Seis propostas para o próximo milênio. 
No segundo subcapítulo serão abordados elementos metafóricos considerados nesta tese como os mais emblemáticos da literatura coralineana e manoelina, referindo-se à confecção poética da "cozinha" e do "quintal". Será abordada desde a representatividade desses elementos na formação cultural e identitária do país - especialmente nos interiores - até sua relevância simbólica e metafórica na atmosfera da infância presente na obra de Cora Coralina e Manoel de Barros.

Ao terceiro subcapítulo caberá a abordagem dos elementos subjacentes às metáforas da "cozinha" e do "quintal" que, construídos pela simplicidade poética de Cora Coralina e Manoel de Barros, refletem a essência identitária do Brasil. Destacase a importância das literaturas de ambos no processo de formação de leitores conscientes de sua ancestralidade cultural e, principalmente, percebendo-se o quanto elas podem contribuir para enriquecer na contemporaneidade sua concepção de Brasil e, sobretudo, de infância: não de uma infância qualquer, mas daquela repleta de poesia.

Dessa forma, encerra-se esta parte do trabalho objetivando oferecer uma visão enriquecedora e plural da obra de Cora Coralina e Manoel de Barros, e o quanto a literatura de ambos pode colaborar para que se possa transmitir ao leitor a vivacidade e a beleza que residem tanto da infância da palavra, por meio do texto poético, quanto na infância dos interiores do país, onde cozinhas e quintais expressam, acima de tudo, empatia, acolhimento e liberdade.

\section{1 - Poesia da simplicidade em Cora Coralina e Manoel de Barros}

Sob vários aspectos, a infância é um período de experimentação. É comum ver a criança, diante de um brinquedo, por exemplo, tentar desmontá-lo, sentir seu gosto, seu cheiro, sua textura, sua resistência e ou flexibilidade, jogá-lo para longe e ao mesmo tempo trazê-lo para perto, observá-lo atentamente na tentativa de extrair toda a sua essência.

Assim também a criança experimenta a palavra, ela brinca com sua forma, desmonta sua estrutura, observa seus traços, prova seus sentidos. Para a criança, o sentido racional, denotativo, referencial da palavra the diz pouco, limita sua percepção, sua experiência na maioria das vezes intuitiva, sensitiva. Ela - a criança - almeja mais, vislumbra mais, imagina mais. 
A própria concepção da palavra "criança”, em sua acepção simbólica primeira, de acordo com o Dicionário de Símbolos, é a da inocência enquanto

(...) estado anterior ao pecado e, portanto, o estado edênico, simbolizado em diversas tradições pelo retorno ao estado embrionário, em cuja proximidade está a infância. Infância é símbolo de simplicidade natural, de espontaneidade (...). A criança é espontânea, tranquila, concentrada, sem intenção ou pensamentos dissimulados (Lao-tse, 55, comentado em Tchuang-tse, cap. 23). Esse mesmo simbolismo é empregado na tradição hindu, na qual o estado de infância é denominado balya: é, exatamente como na parábola do Reino dos Céus, o estado prévio à obtenção do conhecimento. (CHEVALIER, GHEERBRANT, 2007, p. 302)

Como Cora Coralina, que mesmo no tarde da vida "(...) recria e poetiza sua própria Vida." (CORALINA, 2014, p. 27), a criança também quer recriar-se, também quer poetizar a própria vida e para isso ela precisa que as palavras transcendam sua significação e ou aplicação prosaica, projetando-se para o rítmico, metafórico, sinestésico, poético.

Nesse cenário, o caráter gramatical da palavra importa menos, pois engessa a estrutura, tolhe as percepções, exige dela - criança - algum conhecimento sistêmico que não é bem-vindo, pelo menos ainda não, nesse sentido, como o próprio Manoel de Barros sinalizara: "A criança erra na gramática e acerta na poesia." ${ }^{48}$.

Quando se leva em consideração a capacidade de desnudar a palavra, de explorar suas possibilidades e suas potencialidades, de extrair sua essência, a criança é um leitor infinitamente mais voltado à poesia do que à prosa e, se comparada ao adulto, por ainda estar desvencilhada de parte significativa das mordaças sociológicas do contexto em que está inserida, é também um leitor mais livre, de percepção mais crítica, porque mais aguçada, sensível às nuances, às conotações, às metáforas, às sinestesias, aos ritmos; longe do endurecimento racionalizado do mundo adulto.

Evidenciadas tais questões, ao longo das análises feitas nos capítulos anteriores, em alguns momentos houve referências à obra As seis propostas para 0 próximo milênio, em que Ítalo Calvino apresenta como características imanentes da linguagem que a literatura - mais especificamente a poesia - abarca: leveza, rapidez, exatidão, visibilidade, multiplicidade, consistência. Todavia, no que

${ }^{48}$ Declaração de Manoel de Barros no documentário "Só dez por cento é mentira". Produção de Artezanato Eletrônico; Co-Produção Vite Produções; filme de Pedro Cezar, 2009. 
concerne à literatura infantil, visando atender às demandas desse pequeno leitor do novo milênio, foi proposto um novo elemento complementar à teoria de Calvino: a simplicidade.

Evidentemente que a sustentação para esta teoria reside tanto na literatura de Cora Coralina quanto na de Manoel de Barros, no entanto, antes de se discorrer sobre o modo como as obras atendem à proposta desta tese, é plausível recorrer às acepções da palavra simplicidade, para que não pairem dúvidas sobre a terminologia escolhida:

Simplicidade (substantivo feminino): 1. Qualidade daquilo que é simples. 2. Forma simples e natural de viver, ou de dizer, ou de escrever, etc. ${ }^{49}$

Salienta-se que a apresentação das acepções do termo "simplicidade" são necessárias apenas para sinalizar que não se está, nem de longe, tentando associálo a alguma espécie de simplismo que levaria à pobreza do texto, ou mesmo da linguagem, ou ainda da construção poética de Cora Coralina e Manoel de Barros. Ao contrário, o intuito é destacar exatamente a autenticidade, a sofisticação, a elegância, a espontaneidade e a autenticidade subjacentes às coisas feitas com simplicidade.

Tal elucidação é necessária porque se acostuma ver na arte o termo "simplicidade" ser comumente empregado de modo pejorativo, entretanto se falará em favor dele dada sua recorrência na temática tanto de ambos os autores, simplicidade na linguagem poética corroborada pela simplicidade no estilo de viver.

Interessante pensar inicialmente sobre a proximidade entre as acepções do termo "simplicidade" e as acepções simbólicas do termo "criança", mencionadas no início desta tese, e, mais do que isso, o quanto elas dialogam profundamente não só com a postura dos autores diante da linguagem, da literatura e da própria vida, mas, sobretudo, com as obras poéticas de Cora Coralina e Manoel de Barros, enfatizando especialmente as voltadas para os pequenos leitores e contempladas nesta pesquisa.

A literatura de Cora Coralina fora escrita em meio a muito trabalho, ora no comércio, ora nos roçados, ora na feitura de doces, atividades que, embora

\footnotetext{
49 FERREIRA, Aurélio Buarque de Holanda. Miniaurélio: o minidicionário da língua portuguesa dicionário / Aurélio Buarque de Holanda Ferreira; coordenação de edição Marina Baird Ferreira; equipe de lexicografia Margarida dos Anjos. - 7ª̣ edição - Curitiba. Editora Positivo; 896p., 2008.
} 
extenuantes, não tiraram dela a ternura, a capacidade de receber as pessoas - em especial, as mais jovens - e, principalmente, a solidariedade, como por exemplo, o emblemático caso de Maria Grampinho ${ }^{50}$.

Ao longo da obra coralineana figuram parcela significativa dos excluídos da sociedade: meninos de rua, prostitutas, encarcerados, desvalidos, escravos de outrora. Cora Coralina olhou com ternura para todos eles, sem deixar de atentar-se às gerações futuras ${ }^{51}$. Recebia a todos em sua casa sem quaisquer distinções, sempre lúcida e, sobretudo otimista diante da vida.

Em tempos de acentuada ausência de empatia e acolhimento, o exemplo de vida de Cora Coralina é um alento, um lampejo de esperança, uma prova de que, por meio da simplicidade no ato de receber, o ser humano pode resgatar o que nele há de humano, pois ecoa constantemente na obra da poeta goiana a mensagem de que:

\begin{abstract}
A vida é sempre boa, saber viver é a grande sabedoria e nós todos temos a faculdade de fazer sempre a vida melhor, porque nós, além da vida material que está a nossa volta, temos também a nossa vida interior mais válida do que essa vida material que vivemos, porque a vida é boa e nós todos podemos sempre fazê-la melhor e o melhor da vida é o trabalho. ${ }^{52}$
\end{abstract}

Não se trata de romantizar o trabalho e ou o sofrimento de uma mulher. Ao contrário, trata-se, sim, de uma mulher que, por meio de muito trabalho duro, desafiou preconceitos de seu tempo, ranços de uma sociedade patriarcal, dissabores de um tardio reconhecimento no meio literário - e ainda incipiente no meio acadêmico. Nenhuma dessas questões abalou Cora Coralina; fortaleceu-a, transmitindo-Ihe a consciência da dignidade que reside no trabalho bem feito, ainda que modesto, ilustrando igualmente a beleza na simplicidade da vida:

Tudo que houver de fazer com as suas mãos... que faça bem feito. Se você tiver que fazer um crochê, compre o melhor tipo de linha e faça da melhor

\footnotetext{
${ }^{50}$ Um de seus maiores gestos de amor ao próximo foi permitir que Maria da Purificação dormisse na Casa Velha da Ponte durante 29 anos e, aqui, representa tantas outras Marias amparadas por Cora Coralina. Maria era uma andarilha, negra, pobre (...) Quando Cora regressou para Goiás, em 1956, Maria já dormia todas as noites no quintal da Casa da Ponte. (BRITTO; SEDA, 2009, p. 354)

${ }_{51}$ Cora incentivava os jovens a participar da vida cultural e política, a expressar suas ideias, a escrever. Tanto que apoiou a criação do jornal Papyrus, na cidade de Goiás. Lançado em setembro de 1980 (...) Cora ficou muito entusiasmada e se responsabilizou por uma coluna fixa (...) intitulada 'Fala papyrus'. (...) A preocupação com o futuro dos jovens era uma constante na vida da mulher Cora Coralina. (BRITTO; SEDA, 2009, p. 349)

${ }^{52}$ Declaração de Cora Coralina, registrada no filme-documentário "Cora Coralina - Todas as Vidas". Produzido por Marcio Curi, Beth Curi e Carmem Flora. Roteiro de Renato Barbieri e Regina Pessoa. AsaCine Produções. 2015.
} 
forma, se tiver que fazer um tricô, a mesma coisa; se tiver que fazer uma costura, igualmente; se tiver que lavar uma panela 'coscorenta' e toda enfumaçada, faça com amor. Tudo que se faz com amor, é digno de ser feito e eleva o seu nome e eleva, sobretudo, o seu espírito pela consciência de que fez bem feito. Essa é a minha teoria e me serviu muito. ${ }^{53}$

Simplicidade subjacente em sua literatura de um modo geral, sua estética, dançando entre a poesia e a prosa cujos aspectos narrativos, delicadamente tecidos em versos, apresentam ao leitor uma temática com cheiro de terra molhada, natureza em estado bruto, de roça de milho, de casa de avó, de trabalho duro na gleba, de paisagens bucólicas de um Brasil profundo, misteriosamente, curiosamente, belamente familiar.

Sob tais aspectos, pode-se dizer que a obra poética de Cora Coralina traduziu a simplicidade da vida e do trabalho, os excluídos de hoje e de outrora, por meio de linguagem e estética simples. Em seu primeiro livro - Poemas dos becos de Goiás e estórias mais - Cora Coralina explicita ao leitor, por meio do texto "Este livro", a simplicidade da temática que permeará toda a sua obra:

Este livro pertence mais aos leitores do que a quem o escreveu.

Que o saiba sempre em brochura, ao alcance de crianças, jovens e adultos, que mãos operárias repassem estas páginas e sintam-se presentes, junto à mulher operária que as elaborou.

Que possa ultrapassar as cidades e alcançar a alma sertaneja, levando minha presença-terra aos enxadeiros e boiadeiros que tanto me ensinaram.

Que entre em casas de mulheres marcadas de luz vermelha e leve a elas esta Mensagem do Evangelho:

Disse-Ihes Jesus: Em verdade vos digo que publicanos e meretrizes entrarão na vossa frente no reino de Deus.

Possa ser lido nas prisões e levar ao presidiário a última página deste livro num apelo de regeneração e na minha oferta de fraternidade humana.

Tenha ele sempre uma apresentação simples e sugestiva e, por muito tempo, possa viver fora das encadernações de luxo entre lombadas hieráticas e dourados bonitos.

Possa valer pelo seu conteúdo, sempre encontrado em bancas populares e em balcões de livrarias - seu preço ao alcance de um leitor modesto.

Com o tempo, lido, relido e trelido, rabiscado, amassado, arrancadas as folhas, seja, num dia de faxina geral, num auto de arrumação e limpeza, lançado numa fogueira e calcinado no holocausto das chamas.

Vai, meu pequeno livro. Que possa sobreviver à Autora e ter a glória de ser lido por gerações que hão de vir de gerações que vão nascer. (CORALINA, 2014, p. 23-24)

\footnotetext{
${ }^{53}$ Declaração de Cora Coralina, registrada no filme-documentário "Cora Coralina - Todas as Vidas". Produzido por Marcio Curi, Beth Curi e Carmem Flora. Roteiro de Renato Barbieri e Regina Pessoa. AsaCine Produções. 2015.
} 
É preciso ressaltar ainda que, devido a sua atuação em prol das pessoas mais pobres e marginalizadas, a figura da escritora, ainda em vida, passou a ocupar espaço privilegiado na vida social de Goiás. Cora Coralina passou a ser enxergada não apenas como uma figura ilustre que era, mas como um símbolo de bondade, acolhimento, simplicidade, portanto. Seu grau de empatia, identificação e cultura eram tamanhos e foram poeticamente ilustradas no texto "Todas as Vidas" (Anexo $\mathrm{XI}$ ), em que o eu poético coralineano se projeta metaforicamente em profundas experiências femininas, numa singular experiência de alteridade.

No que tange à obra de Cora Coralina elaborada para crianças, entende-se ser a simplicidade a característica que garante a poeticidade da linguagem, não apenas porque reside num vocabulário possível, de fácil compreensão, apetecível ao pequeno leitor, mas também porque não perde a delicadeza e a ternura do olhar infantil e, sobretudo, porque capta o modo holístico sob o qual a criança naturalmente percebe o mundo a sua volta.

Cora Coralina fecha um ciclo pessoal ao retornar para a Casa Velha da Ponte, como o herói de Joseph Campbell, ciclo este metaforizado em sua obra, uma vez que o eu poético migra da posição de ouvinte em O Prato Azul-Pombinho para a posição de contador de histórias em Os Meninos Verdes. De bisneta a avó, a poetiza garante, por meio da simplicidade de sua literatura, o infinito da obra, que “(...) numa tal perspectiva, é tão só o infinito do próprio espírito. O espírito quer realizar-se numa única obra, em vez de realizar-se no infinito das obras e no movimento da história." (BLANCHOT, 2011, p. 12).

Dessa forma, Cora Coralina produziu uma literatura cuja poeticidade reside na simplicidade da linguagem e da forma, porque repleta de um olhar empático, acolhedor, simples - não simplório -, capaz de transportar o leitor para um cenário poético, que mesmo distante de seu contexto de vida, arrebata-o ternamente, proporcionando-Ihe viajar ora para a Fazenda Paraíso, ora para a Casa Velha da Ponte, ora para os becos de Goiás. É na ternura desse processo de acolhimento que reside a poesia de Cora Coralina.

O elemento simplicidade também é componente basilar da literatura de Manoel de Barros. Inúmeras vezes a ideia de brincar com as palavras é reforçada pelo "eu" poético. Mais do que isso, para o poeta a poesia só é possível dessa forma: brincando, subvertendo os sentidos da palavra, transgredindo suas 
estruturas; fazendo ecoar, por meio de uma estética liberta das amarras gramaticais, um mundo mais livre e, portanto, mais poético imanente ao imaginário infantil.

Embora Manoel de Barros tenha gozado de condição social que lhe permitisse ser poeta em tempo integral, sua vida também fora pautada pelo jeito simples de viver. Mesmo sendo um dos mais vendidos autores do país, não ficou mais que uma década longe de seu pantanal mato-grossense; preferiu uma vida longe dos holofotes, da pompa, da fama; raras vezes concedeu entrevistas; cercouse dos amigos que cultivara desde a infância, poetizando-os inclusive, como no caso de Bernardo ${ }^{54}$.

A simplicidade da poesia de Manoel de Barros consiste fundamentalmente no seu trabalho estético com a palavra, num processo de constante invenção. O próprio poeta afirma isso, negando quaisquer outros interesses:

\begin{abstract}
A minha poesia é fertilizada pelo Sol, pelas águas, pelo chão do Pantanal, ela é fertilizada... a palavra, ela não me serve a mim para descrever paisagem... poesia não é um fenômeno de paisagem... é um fenômeno de linguagem. Eu sou nascido no Pantanal, sou filho do Pantanal, gosto do Pantanal, tenho amor pelo Pantanal, sou criado no Pantanal... o que me dá dinheiro... o que me dá o ócio é o Pantanal... mas eu sou um poeta da palavra... e ninguém quer entender isso... pouca gente quer entender isso... que eu não sou poeta de paisagem... não sou poeta ecológico, não quero fazer folclore... não quero expressar costumes... não sou historiador... eu sou poeta... poeta é um sujeito que inventa... eu invento o meu Pantanal. ${ }^{55}$
\end{abstract}

Entretanto, apesar das negações - as quais, tomadas literalmente, poderiam direcionar apenas para questões de ordem estrutural, metalinguística, centralizando nossa abordagem unicamente sob o viés da forma - considera-se que é justamente esse processo de invenção que liberta a percepção do leitor, abrindo-lhe as portas do imaginário, proporcionando a eclosão do caráter poético da linguagem, ou seja, no fim das contas, o Pantanal de Manoel de Barros é o Pantanal poético de todos.

Isso porque é na simplicidade das construções imagéticas da poesia de Manoel de Barros que se desenha o fenômeno de relação identitária com o leitor, no sentido de que não “(...) há identidade em si, nem mesmo unicamente para si. A identidade existe sempre em relação a uma outra. Ou seja, identidade e alteridade são ligadas e estão em uma relação dialética." (CUCHE, 2002, p. 183).

\footnotetext{
${ }^{54}$ Amigo de infância de Manoel de Barros, que o acompanhou por toda a vida. Registrado no documentário "Só dez por cento é mentira". Produção de Artezanato Eletrônico; Co-Produção Vite Produções; filme de Pedro Cezar, 2009.

${ }^{55}$ Declaração de Manoel de Barros no documentário "Só dez por cento é mentira". Produção de Artezanato Eletrônico; Co-Produção Vite Produções; filme de Pedro Cezar, 2009.
} 
Relação dialética essa que brota de imagens, embora paradoxais, sinestesicamente produzidas dentro de um campo semântico concebível num universo capaz de permitir à palavra libertar-se de sua função referencial, em versos cuja poeticidade é garantida pela simplicidade.

Simplicidade que ocupa abundantemente a construção dos versos do escritor, cuja estética reflete, de modo recorrente, a ideia visceral de liberdade e de comunhão com a natureza presente especialmente na infância, resgatada pela memória do eu poético.

Assim, embora o autor seja assumidamente um admirador da obra Padre Antônio Vieira, ao contrário da estrutura adotada pelo poeta barroco, a construção poética de Manoel de Barros não se prende a formas fixas. Sua composição ora de um verso apenas, ora trazendo elementos da narrativa, desenha circunstâncias dotadas de grande simplicidade: brincadeiras, lugares, bichos, objetos e personagens como Bernardo, por exemplo.

O que resulta da simplicidade dessas imagens poéticas é um processo que aguça e seduz os sentidos do leitor, ampliando-lhe a dimensão das coisas a sua volta, como acontece quando somos crianças e estamos brincando em nossos espaços da infância, e estes nos parecem muito maiores do que verdadeiramente são.

Daí a beleza da poesia de Manoel de Barros residir na simplicidade da imagem proporcionada pelo processo de criação poética, que pode ocorrer nas situações mais inusitadas, como exemplifica o próprio poeta: “(..) um amigo meu mandou lá de Brasília um verso de uma menina de sete anos que diz o seguinte: 'Borboleta é uma cor que avoa', eu acho que a infância tem esse poder ${ }^{56 " . ~}$

Dessa forma, a infância que é apresentada ao leitor não pretende dar informações memorialísticas, ou seja, embora o eu poético recorra à memória, o objetivo é propiciar encantamento, por meio de um mundo inconcebível racionalmente, ao menos para o adulto, mas perfeitamente plausível à percepção infantil, mesmo porque “(...) a realidade poética da imagem não pode aspirar à verdade. O poema não diz o que é, mas o que poderia ser. Seu reino não é o do ser, mas o do ‘impossível verossímil' de Aristóteles.” (PAZ, 2012, p. 105).

${ }^{56}$ Declaração de Manoel de Barros no documentário "Só dez por cento é mentira". Produção de Artezanato Eletrônico; Co-Produção Vite Produções; filme de Pedro Cezar, 2009. 
Outro aspecto da simplicidade que necessita ser contemplado diz respeito à voz do eu poético, pois é preciso considerar que se está tratando de um autor cuja maturidade não se transfigurou em instrumento de autoridade em sua poesia, não há modelos a serem seguidos, nem lições a serem ensinadas, tampouco "moral da história" como nos contos de fadas. Ao contrário, no universo poético concebido por Manoel de Barros, eu poético e leitor compartilham de uma relação em que prevalece a empatia, a igualdade, a fraternidade e a comunhão com a natureza.

É nesse cenário que a infância poética se manifesta, uma vez que a poesia “(...) nos abre a possibilidade de ser que todo nascer contém; recria o homem e o faz assumir sua verdadeira condição, que não é a separação vida ou morte, mas uma totalidade: vida e morte num só instante de incandescência." (PAZ, 1982, p. 190).

Ademais outro fator que possibilita ao poeta simplicidade imagética capaz de dialogar com o universo infantil diz respeito à posição de Manoel de Barros diante de seu processo de criação. No documentário "Só dez por cento é mentira" de 2009, ao discorrer sobre a confecção do seu livro Memórias Inventadas, o poeta explicita a temática de toda a sua vida: a infância: “(...) me pediram para fazer um capítulo da minha mocidade, um capítulo da minha velhice, e eu declarei que eu só tive infância.

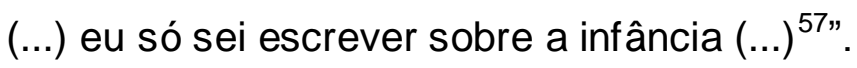

Necessário salientar que se consideram muito importantes as declarações de Manoel de Barros acerca de sua obra, porque, embora evidenciemos a simplicidade que brota das imagens dentro do processo estético do poeta, não podemos ignorar o seu trabalho metalinguístico. Como foi mencionado anteriormente, não foram raros os textos em que a temática era o próprio fazer poético, como em $O$ Livro das Ignorãças. Assim, não seria incorreto inferir que, em várias circunstâncias, o poeta fora também crítico de sua obra.

E, mesmo analisando seu próprio fazer poético, Manoel de Barros não deixa de exortar o leitor a enxergar a simplicidade das coisas, como no texto "Escova" de Memórias inventadas, por exemplo, em que o eu poético, ainda criança, buscava escovar a palavra até extrair dela a máxima potência de sua significação. Além de poético, tal ato fora primeiro enxergado como uma grande brincadeira.

\footnotetext{
${ }^{57}$ Declaração de Manoel de Barros no documentário "Só dez por cento é mentira". Produção de Artezanato Eletrônico; Co-Produção Vite Produções; filme de Pedro Cezar, 2009.
} 
Essa brincadeira com a palavra permeará toda obra do poeta. O "eu" poético convida o leitor a despir-se do apelo tecnológico, digital e virtual, próprio da contemporaneidade e convida-o a "transver o mundo", a "ver o canto dos pássaros", a andar descalço pela terra do imaginário.

Evidentemente que tais ações devem causar, no mínimo, estranhamento, especialmente ao pequeno leitor que reside nos grandes centros urbanos do país, no entanto defende-se que o convite a um reino em que as palavras são livres de quaisquer amarras da razão não deixa de encantá-lo.

Isso porque se deve “(...) considerar que a identidade se constrói e se reconstrói constantemente no interior das trocas sociais." (CUCHE, 2002, p. 183). Sob tal aspecto, o contexto sociológico ao qual o leitor pertence importa menos, uma vez que nesse cenário, o que importa é a poeticidade, a fantasia, a sensação de plenitude e liberdade a partir da simplicidade de cenários que transcendem a vivência bucólica pura e simples, penetrando o âmago da natureza do homem e da palavra.

Ou seja, na literatura de Manoel de Barros, o leitor não é convidado a conhecer, ou mesmo penetrar o universo, ainda que metaforicamente, do Pantanal propriamente dito, embora em muitos casos, ele - o Pantanal - figure nas ilustrações dos versos do poeta. O Pantanal apresentado ao leitor é um outro, místico, insólito, maravilhoso, onde todos os elementos comungam, construindo uma relação de harmonia, comunhão, empatia, fraternidade entre o eu poético e os elementos que compõem a natureza.

É essa relação a responsável pelo estreitamento no que concerne à identificação entre o eu poético e o leitor, pois a simplicidade resultante da construção poética de Manoel de Barros na confecção de um Pantanal e de uma infância pertencentes a uma esfera fantástica, maravilhosa, libertadora, passa a pertencer a todos. Uma vez que o

“(...) que nos é dado por um contato a distância é a imagem, e o fascínio é a paixão da imagem. O que nos fascina, nos arrebata o nosso poder de atribuir um sentido, abandona a sua natureza "sensível" (...), afirma-se numa presença estranha ao presente do tempo e à presença no espaço." (BLANCHOT, 2011, p. 24).

Assim sendo, pretende-se realçar a imanência da simplicidade tanto em relação ao fazer poético de Cora Coralina quanto ao de Manoel de Barros, reconhecendo ainda que a dialética existente entre as obras transcende as 
eventuais disparidades estéticas, tocando a sensibilidade do leitor de múltiplas formas, mesmo porque a

(...) identidade é tão difícil de se delimitar e de se definir, precisamente em razão de seu caráter multidimensional e dinâmico. É isto que the confere sua complexidade mas também o que lhe dá sua flexibilidade. A identidade conhece variações, presta-se a reformulações e até a manipulações. (CUCHE, 2002, p. 196)

A criação poética de Cora Coralina se volta para espaços da casa, em especial à cozinha, e para circunstâncias que envolvem contação de histórias como instrumento de aproximação entre a criança e o adulto, mais especificamente entre netos e avós, numa atmosfera acolhedora, materna. A de Manoel de Barros contempla o esplendor do quintal e a sensação de liberdade e comunhão que são proporcionadas pela valorização das nuances desse espaço, que também constitui uma atmosfera igualmente acolhedora; entretanto nesse caso é a pujança da natureza quem acolhe.

Não se pode deixar de salientar o valor simbólico que tais espaços - cozinha e quintal - ocupam na concepção cultural do Brasil dos interiores, simbolizando um período em que pessoas se reuniam na cozinha, enquanto crianças brincavam no quintal. Daí considerar-se a simplicidade como elemento preponderante na poesia de Cora Coralina e de Manoel de Barros, capaz de suscitar no leitor ecos culturais e identitários, independentemente do contexto em que ele esteja inserido.

Tais questões coadunam com o pensamento de Baudrillard, por ponderar que

(...) a relação com outros, hoje, que pode ser uma relação psicológica, social, etc., tenha um pouco dessa dimensão transitiva, transversal, vetorial; a rigor, que mais não se faça do que circular no desejo dos outros, na relação com os outros. Pode-se imaginar uma relação com os outros forte, com um desejo próprio, uma descoberta do outro, do afeto, tudo o que poderia constituir paixões, com uma certa intensidade. E também, pode-se imaginar efetivamente o outro como lugar de desterritorialização, pura e simplesmente. Quer dizer que o outro existe, mas é feito para ser atravessado; de certa maneira, pode-se viver no desejo do outro, mas como no exílio, numa outra dimensão, de fundo holográfico. É quase por um holograma, nesse momento, que você pode passar. (BAUDRILLARD, 1994, p. $91-92)$

Sob tal aspecto, é singular o efeito que a confluência entre as literaturas de Cora Coralina e Manoel de Barros podem proporcionar ao leitor, a visão de um Brasil permeado de infâncias cujos maiores recursos tecnológicos residem na capacidade de alimentar a imaginação seja ouvindo histórias, seja brincando com os 
sentidos da palavra. Em ambos os processos prevalece o caráter maravilhoso, a magia, a possibilidade de criar universos mais belos, repletos de fantasia.

3.2 - Por uma infância poética: entre doces na cozinha e brincadeiras no quintal

As percepções adquiridas na infância acompanham o ser humano por toda a vida. Não é incomum o adulto ser arrebatado por aromas, sabores, circunstâncias que, experimentados na infância, deslocam sua imaginação para um tempo do qual inexplicavelmente sente falta, independentemente da condição sociológica na qual estava inserido. A infância constitui um período em que as questões práticas da vida importam menos.

A principal preocupação de toda criança é brincar. Para isso ela utiliza tudo que dispõe a sua volta e, valendo-se da natural fecundidade de sua imaginação, transforma desde os objetos mais simples, como paus, pedras, ou mesmo um caco de vidro - como o eu poético coralineano em O Prato Azul-Pombinho - até os mais sofisticados, como a infinidade de apetrechos digitais que permeiam a infância na contemporaneidade.

Além do mais, quando se faz referência à busca de uma infância poética, valendo-se da força imagética atribuída aos elementos "cozinha" e "quintal", isso se deve ao valor que lhes é dado nas obras coralineana e manoelina, mas também no contexto histórico, sociológico e cultural do país. Isto é, pretende-se demonstrar a seguir a força e a concretude desses elementos para Cora Coralina e Manoel de Barros e o modo como ambos compõem o cenário infantil dos interiores do país.

Poucas searas representam tão bem a essência da pluralidade e a riqueza cultural brasileira quanto a culinária. A despeito da barbárie que tantas vezes regeu o processo de miscigenação étnico-cultural entre os povos no Brasil, há uma misteriosa simetria na harmonização de aromas, temperos, texturas, ingredientes de todos os lugares que, ao longo da história, compuseram sabores até então inéditos no mundo, reconhecidos hoje como tipicamente brasileiros.

Da mesma forma como há na literatura de Cora Coralina e Manoel de Barros uma proficuidade no que tange às combinações entre os gêneros textuais em poesia e prosa, também não há limites para as possibilidades de combinações na culinária brasileira. A harmonia que nela existe parece não condizer com o contexto de 
violência que a possibilitou, principalmente em relação a nativos e a negros cuja contribuição fora essencial para a singularidade tanto de nossa poesia quanto dos sabores de nossa culinária.

Assim, ao longo da história, a cozinha transcendeu a representação de simples espaço de preparação de alimento, para configurar-se como espaço de construção de identidade cultural. Além disso, a cozinha, durante muito tempo, representara também lugar de trabalho duro e de confinamento de mulheres e crianças - especialmente meninas - (provavelmente dessa visão nasceu o retrógrado, machista e démodé ditado popular: "Lugar de mulher é na cozinha.").

No entanto traduz-se na obra da poeta exatamente como o oposto, ou seja, como espaço de aprendizado, de liberdade, de florescimento de histórias. Cora Coralina fez da cozinha um dos principais espaços poéticos de toda a sua obra. Mais do que isso, doceira de profissão, a cozinha desde a meninice ocupara o imaginário da pequena Anninha não apenas porque constituía o espaço da feitura de doces, mas, sobretudo, porque era também o espaço onde a família se reunia e brotavam as histórias. Talvez por isso suas metáforas poéticas raramente privilegiem espaços abertos - o "Poema do Milho" é uma exceção à regra.

A cozinha na poesia de Manoel de Barros compõe um espaço majoritariamente materno, mas também de lugar onde a família se reúne não apenas para o jantar, mas também para que o diálogo aconteça. Interessante pensar nesses diálogos muitas vezes como embates filosóficos entre o pai e amigo "doutor", ou ainda entre mãe e filho a respeito de suas traquinagens com a palavra.

Em relação ao quintal, este, raro nos grandes centros, mas ainda comum nos interiores, parece representar o que há de indígena em todos, na sua relação simbiótica com a terra. Sempre se pensa no quintal como um espaço da natureza nas casas, seja um jardim, seja um pomar, ou mesmo os dois. O fato é que há na imagem do quintal, um espaço de refúgio, capaz de proteger e encantar, conduzindo as pessoas a um universo maravilhoso tão presente e emblemático na atmosfera da infância nos interiores.

Na poesia coralineana, o quintal constitui justamente esse espaço de refúgio, nele, a pequena Anninha protegia-se de todas as agruras de sua infância, fazendo da natureza sua grande companheira. Nesse sentido, como se pode observar em "Menina Mal-Amada" (Anexo XVIII), o quintal fora, durante muito tempo, lugar 
mágico, mas também proibido pela mãe da pequena Anninha, que não queria sua filha vagando pelo quintal, temendo pelo enlouquecimento da menina.

Já na poesia de Manoel de Barros o quintal metaforiza a sensação de liberdade, de comunhão com a natureza, lugar onde as palavras podiam ser "escovadas" até se extrair delas a essência de sua significação. Como se mencionou anteriormente, na dinâmica urbana contemporânea, especialmente das metrópoles, quintais são raros, no entanto ainda são fortemente presentes nos interiores do Brasil, possuindo ainda a mesma representatividade para o universo infantil, ou seja, o quintal é, acima de tudo, um espaço de brincadeiras.

Nesse cenário, além do elemento simplicidade, abordado no subcapítulo anterior, que atribui poeticidade às imagens resultantes das linguagens poéticas coralineana e manoelina, há também em ambos a questão da voz poética que resgata a memória sem autoritarismo nem moralismo, apenas evidenciando a beleza da infância e, sobretudo, a capacidade inerente à criança de converter quaisquer situações, adversas ou não, em brincadeiras.

Como se defendeu desde o início desta tese, nenhuma linguagem tem mais recursos e, portanto, é mais eficaz do que a linguagem poética para traduzir, além da poesia imanente às questões da infância de um modo geral, reminiscências de outrora carregadas de ternura e brincadeira, tanto em Cora Coralina quanto em Manoel de Barros.

Ademais, defende-se ainda ser o texto poético, por representar a infância da linguagem, aquele capaz de manifestar o que há de mais puro, belo e visceral nas entranhas dos povos, de suas culturas, de suas identidades. Atando esse pensamento ao de Octavio Paz, entende-se que a poesia

(...) vive nas camadas mais profundas do ser, enquanto as ideologias e tudo o que denominamos ideias e opiniões são os estratos mais superficiais da consciência. O poema se alimenta da linguagem viva de uma comunidade, de seus mitos, seus sonhos e paixões, ou seja, de suas tendências mais secretas e poderosas. O poema funda o povo porque o poeta recua na correnteza da linguagem e bebe na fonte original. No poema a sociedade se confronta com os fundamentos de seu ser, com sua palavra primeira. Quando proferiu essa palavra original, o homem se criou. Aquiles e Odisseu são algo mais que duas figuras heroicas: são o destino grego criando a si mesmo. O poema é mediação entre a sociedade e aquilo que a funda. Sem Homero, o povo grego não seria o que foi. O poema nos revela o que somos e nos convida a ser o que somos. (PAZ, 2012, p. 48-49) 
Considerando tais aspectos, bem como o contexto brasileiro, sabe-se que os textos dedicados a retratar a infância oscilaram, segundo Marisa Lajolo ${ }^{58}$, entre a "representação idílica", como no poema "Meus oito anos" de Casimiro de Abreu e a representação de uma vida "amarga e dura", como no conto "Piá não sofre? sofre" de Mário de Andrade, destacando ainda - até como clichê - a prevalência daquela visão em detrimento desta.

De qualquer forma, independentemente da representação, ainda segundo Lajolo, inaugura-se, já em Pero Vaz de Caminha, a visão de um narrador cuja perspectiva “(...) se prolonga e se consolida em representações posteriores da infância: a perspectiva adulta (...)" (LAJOLO, 2006, p. 234). Assim, embora se reconheça que tanto na poesia de Cora Coralina quanto na de Manoel de Barros a questão do resgate memorialístico esteja presente - o que por si só caracterizaria a perspectiva adulta - entende-se que a abordagem de ambos transcende a oscilação mencionada no parágrafo anterior.

Ou seja, defende-se que as literaturas coralineana e manoelina tratam a infância como um período em que, a despeito de todas as privações, dificuldades e sofrimentos que, vale ressaltar, não obliterados pelos autores, a preocupação maior da poesia de ambos é extrair a beleza, a fantasia, ou melhor, o poético que residem nas experiências infantis desenhadas ao longo das obras.

Dessa forma, Cora Coralina e Manoel de Barros apresentam uma infância em que a preocupação mais latente do eu poético é ora brincar, ora ouvir histórias, todavia não da forma edênica, saudosista, quase melancólica, tampouco evidenciando dificuldades subjacentes a esse período, mas poetizando lugares, circunstâncias, ambientes, até pessoas, resgatando um Brasil para além da complexidade das questões sociológicas que o cercam.

Trata-se, portanto, de oferecer ao leitor a possibilidade de se conectar ao Brasil profundo, onde a cozinha goiana coralineana e o quintal mato-grossense manoelino, mesmo distantes dos contextos urbanos das metrópoles do país, pertencem a todos, pois compõem um cenário imagético que vislumbra a beleza de uma infância em que crianças reúnem-se em torno de seus avós para ouvir histórias, em que o peso do trabalho rural é compensado pelo aroma exalado dos roçados de

\footnotetext{
${ }^{58}$ LAJOLO, Marisa. "Infância de papel e tinta". In História Social da Infância no Brasil / organizador Marcos Cezar de Freitas. - 6를 ed. - São Paulo: Cortez, 2006. Páginas 229 - 250.
} 
milho, em que é possível observar, sem maiores preocupações, formigas, pássaros e riachos.

Embora possuam estéticas diferentes, na literatura produzida por ambos é possível reconhecer que, se

(...) a identidade cultural é uma construção social e não um dado, se ela é do âmbito da representação, isto não significa que ela seja uma ilusão que dependeria da subjetividade dos agentes sociais. A construção da identidade se faz no interior dos contextos sociais que determinam a posição dos agentes e por isso mesmo orientam suas representações e suas escolhas. (CUCHE, 2002, p. 182)

Como se afirmou anteriormente, não se entendem tais aspectos como simples abordagens de uma infância sob a égide do saudosismo, do bucolismo, ou mesmo do romantismo. Ao contrário, enxerga-se na literatura de Cora Coralina e de Manoel de Barros a possibilidade de o leitor experimentar uma infância poética tão concreta, viva e presente no imaginário quanto os sabores da infância ou as brincadeiras no quintal.

Todos os leitores são assim convidados a experimentar o universo infantil e poético de Cora Coralina e Manoel de Barros, dadas as percepções que lhes são oferecidas poeticamente, provocando o que Alfredo Bosi elucida ao abordar a Teoria da Forma:

A Teoria da Forma ensina que a imagem tende (para nós) ao estado de sedimento, de quase-matéria posta no espaço da percepção, idêntica a si mesma. Cremos "fixar" o imaginário de um quadro, de um poema, de um romance. Quer dizer: é possível pensar em termos de uma constelação, se não de um sistema de imagens, como se pensa em um conjunto de astros. Como se objeto e imagem fossem dotados de propriedades homólogas.

Mas é a mesma ciência que nos adverte do engano (parcial) que a identificação supõe. A imagem não decalca o modo de ser do objeto, ainda que de alguma forma o apreenda. Porque o imaginado é, a um só tempo, dado e construído.

Dado, enquanto matéria. Mas construído, enquanto forma-para o sujeito. Dado: não depende da nossa vontade de receber as sensações de luz e cor que o mundo provoca. Mas construído: a imagem resulta de um complicado processo de organização perceptiva que se desenvolve desde a primeira infância. (BOSI, 1977, p. 15)

\section{3 - Cozinha e quintal: da periferia ao centro}

O Brasil é um país plural. Seu povo, suas manifestações artísticas, sua culinária, seu folclore, seu sincretismo religioso comprovam a cada segundo 0 processo antropofágico de sua gente, de sua cultura e também de sua identidade, já sinalizado pelo movimento modernista no início do século XX. É verdade que todos 
os povos, especialmente nas Américas, possuem em seu processo de formação, em menor ou maior grau, algum sincretismo.

No entanto, no caso do Brasil, esse caráter sincrético compõe sua gênese, está em suas entranhas, nativos e lusitanos num primeiro momento, angolanos, moçambicanos em seguida, daí por diante, imigrantes vieram e vêm de todas as partes, trazendo em suas malas elementos culturais e identitários que são absorvidos pelo processo antropofágico que rege essa gente. Assim, é válido perguntar: há uma essência identitária brasileira? E, caso haja, como buscá-la diante de tamanha pluralidade?

Tais questões são corroboradas pelo fato de se compreender que, na

(...) medida em que a identidade resulta de uma construção social, ela faz parte da complexidade do social. Querer reduzir cada identidade cultural a uma definição simples, "pura", seria não levar em conta a heterogeneidade de todo grupo social. Nenhum grupo, nenhum indivíduo está fechado a priori em uma identidade unidimensional. O caráter flutuante que se presta a diversas interpretações ou manipulações é característico da identidade. É isto que dificulta a definição desta identidade.

Querer considerar a identidade como monolítica impede a compreensão dos fenômenos de identidade mista que são frequentes em toda sociedade. (CUCHE, 2002, p. 192)

Entretanto não se desconsidera o fato de que, mesmo sob a perspectiva de uma cultura multidimensional, quando se trata das experiências infantis, há uma gama de elementos capazes de dialogar profundamente com a ancestralidade, e por que não dizer com a contemporaneidade, das vivências das várias infâncias do país. Esses elementos transcendem a ideia de periferia e centro, tão presente em nossa dinâmica sociocultural, e que podem ser manifestados de várias formas, mas a relevância agora são as manifestações literárias.

Entende-se que na literatura infantil a “(...) perspectiva lúdica é reveladora de uma abordagem criativa que usa a língua como um objeto do jogo. A língua é, assim, um conjunto de sinais manipuláveis em função das regras propostas pelo escritor jogador." (KRYSINSKI, 2007, p. 33). Dessa forma, no caso da literatura de Cora Coralina e Manoel de Barros, além das questões da cozinha e do quintal abordadas anteriormente, outros elementos, evocados pela linguagem poética de ambos, são capazes de suscitar no leitor, por meio da forma como são construídos e da temática que abordam, 
A experiência da imagem, anterior à da palavra, vem enraizar-se no corpo. A imagem é afim à sensação visual. $O$ ser vivo tem, a partir do olho, as formas do sol, do mar, do céu. O perfil, a dimensão, a cor. A imagem é o modo da presença que tende a suprir o contacto direto e a manter, juntas, a realidade do objeto em si e a sua existência em nós. $O$ ato de ver apanha não só a aparência da coisa, mas alguma relação entre nós e essa aparência: primeiro e fatal intervalo. Pascal: "Figure porte absence et présence." (BOSI, 1977, p. 13)

Será dividida a abordagem entre os elementos que ecoam a essência identitária das infâncias ancestrais e contemporâneas de nosso país, ressaltando que tais fenômenos não são, nem de longe, excludentes. Ao contrário, entrelaçamse numa relação simbiótica, tendo seu efeito potencializado pela estética da linguagem poética tanto em Cora Coralina quanto em Manoel de Barros.

O que faz com que a imagem ancestral ou contemporânea toque a alteridade do leitor, remetendo-o à sua própria essência, é a potência imanente ao texto poético, pois apenas por meio dele a "(...) imagem pode ser retida e depois suscitada pela reminiscência ou pelo sonho. Com a retentiva começa a correr aquele processo de co-existência de tempos que marca a ação da memória: o agora refaz o passado e convive com ele." (BOSI, 1977, p. 13), daí a relação simbiótica à qual referida anteriormente.

No subcapítulo anterior houve referência à "cozinha" e ao "quintal" como elementos primordiais na composição poética das obras coralineanas e manoelinas respectivamente. Agora, ressalta-se as imagens desenhadas pelas estéticas da poesia de Cora Coralina e Manoel de Barros, capazes de suscitar metaforicamente elementos que dialogam, primeiramente, com a essência identitária ancestral, em segundo lugar, com a essência identitária contemporânea.

No que tange à essência identitária ancestral, destaca-se como primeiro aspecto na poesia de Cora Coralina e de Manoel de Barros a relação construída pelo eu poético, em ambas as obras, com o elemento "terra". Trata-se de uma relação dialógica: de um lado, a rapsoda goiana aborda a terra cultivada, que produz, alimenta, evocando o trabalho do homem do campo, afirmando ser "Ele, mesmo, Terra." ${ }^{59}$; de outro lado, o poeta mato-grossense aborda não pelo viés do cultivo, mas pelo viés do pertencimento à "terra". Segundo ele não há "(...) nenhum espetáculo mais edificante do que pertencer do chão." 60

\footnotetext{
${ }^{59}$ CORALINA, 2011, p. 14;

${ }^{60}$ BARROS, 2008, p. 33;
} 
Desde a Carta de Pero Vaz de Caminha, a terra, símbolo de maternidade e fecundidade, é evidenciada, e os povos que vieram para o país nos primeiros séculos, bem como os que aqui já estavam, possuíam uma profunda relação com a terra, seja do ponto de vista agrícola, como lusitanos, angolanos e moçambicanos, por exemplo, seja do ponto de vista do pertencimento, como os nativos.

Outro detalhe interessante reside no fato de se poder afirmar que essa relação ancestral com a terra permeia não apenas as obras contempladas nesta tese, mas na bibliografia geral dos autores. Por exemplo, na obra Vintém de Cobre: meias confissões de Anninha, publicado pela primeira vez em 1983, Cora Coralina também sinalizava para o leitor essa relação ancestral com a terra, ilustrada pelos poemas "A Gleba me Transfigura" (Anexo XII) e "Sou Raiz" (Anexo XIII); quanto a Manoel de Barros, pode-se mencionar a obra Gramática expositiva do chão, de 1966, em que essa relação pode ser ilustrada pelo conjunto de poemas "Protocolo vegetal" (Anexo XIV).

Dessa forma, entende-se que o desenho poético envolvendo o elemento "terra" na literatura de ambos os autores incita no imaginário do leitor

(...) algo de irredutível ao funcional, que é como um investimento, que é como um investimento inicial do mundo e de si mesmo pela sociedade com um sentido que não é "ditado" pelos fatores reais, porquanto é ele que confere a esses fatores reais tal importância e tal lugar no universo que constitui para si mesma a sociedade. Sentido que reconhecemos, ao mesmo tempo, no conteúdo e no estilo de sua vida e que chamamos de imaginário central de cada cultura, quer se situe nos símbolos elementares, quer no de um sentido global - o que Hegel chamava de "espírito de um povo". (AZEVEDO, 2018, p. 117)

Além do elemento "terra", a relação entre a criança e o adulto - em especial, o velho -, compõem em ambas as obras um cenário em que rigidez e doçura convivem, de forma a sinalizar para o leitor não apenas como uma reverberação ancestral, mas, sobretudo, como uma necessidade contemporânea, por prevalecer nesse convívio a doçura, a empatia, o acolhimento, enfim, o amor.

Na obra de Cora Coralina, tal fato pode ser percebido tanto na relação entre a avó e seus netos em Os meninos verdes, mas, sobretudo, na obra O Prato AzulPombinho, em que a bisneta, embora castigada, é punida com alguma ternura e preocupação por parte da bisavó, ilustrada especialmente na "NOTA: De como acabou, em Goiás, o castigo dos cacos quebrados no pescoço” (Anexo II). 
No caso da obra de Manoel de Barros, os poemas "Obrar" (Anexo XV) e "O Lavador de Pedra" (Anexo XVI), ambos do livro Memórias Inventadas: as infâncias de Manoel de Barros servem de exemplo para ilustrar a relação entre o eu poético e seus avós, que, como na obra coralineana, também são repletas de empatia e acolhimento.

Reforça-se ainda que, em se tratando do relacionamento entre a criança e o adulto tanto na literatura de Cora Coralina quanto na de Manoel de Barros, e entendido aqui como elemento identitário essencial no processo ancestral e contemporâneo ao mesmo tempo torna-se uma representação para além da ideia de "periferia" e "centro" exatamente porque

Cultura e civilização, tomadas em seu sentido etnológico mais vasto, são
um conjunto complexo que inclui o conhecimento, as crenças, a arte, a
moral, o direito, os costumes e as outras capacidades ou hábitos adquiridos
pelo homem enquanto membro da sociedade. (TYLOR, apud CUCHE,
2002, p. 35)

Ou seja, independentemente do viés sociológico e ou cultural em torno da ideia de "periferia" e "centro", nas obras de ambos os autores, todo "conjunto complexo" supracitado é abarcado por uma confecção poética em que são privilegiadas a ternura, a delicadeza e a harmonia nas relações.

Além disso, outro aspecto não menos importante diz respeito aos elementos poéticos explorados pelos autores que representam a essência identitária das infâncias na contemporaneidade, pois, embora se esteja falando de escritores biologicamente maduros, a literatura de ambos ecoa a vivacidade da infância, e principalmente a capacidade de transformar em brincadeira quaisquer situações, por mais adversas que possam parecer: eis o elemento contemporâneo mais emblemático.

Apesar de condições financeiras razoáveis das famílias de ambos, Cora Coralina e Manoel de Barros tiveram uma infância distante do conceito contemporâneo de luxo; ao contrário, o caráter memorialístico e muitas vezes autobiográfico presentes em ambas as obras ilustram de maneira explícita agruras vivenciadas na meninice.

No caso da autora goiana, pode-se dizer de modo muito breve que ela passara pela infância experimentando acentuado sentimento de rejeição, como se 
pode conferir no poema "Menina Mal-Amada"61 (Anexo XVIII), por exemplo. Nele, o eu poético explicita para o leitor uma espécie de complexo de "gata borralheira" cuja beleza do sentimento da infância, manifestada nos últimos versos, só se revelara anos mais tarde.

Já no caso do poeta mato-grossense, podem-se perceber, de modo recorrente até, questões ligadas a um sentimento de isolamento, acompanhado de dificuldades financeiras, quase sempre supridas de modo criativo pelos pais. O poema "O Menino que ganhou um rio" ${ }^{62}$ (Anexo XVII) ilustra bem essa questão e, embora aparentemente não tenha passado pela infância vivenciando maiores complexos, não quer dizer que o poeta não tenha sofrido com a incompreensão alheia em relação ao seu amor pelas palavras.

De qualquer forma, o que as obras infantis dos dois poetas explicitam para o leitor é a capacidade que a criança tem de superar seus problemas, de transformar em brincadeiras circunstâncias adversas, isto é, ambos mostram o poder que reside na aliança entre a palavra poética, o imaginário e o lúdico no universo infantil, e o quanto tal relação, presente tanto na estética coralineana quanto na manoelina mostram a capacidade que a fantasia tem de arrebatar o leitor, transportando-o, ainda que metaforicamente, para um mundo mais bonito.

Nesse sentido, está o pensamento de Malinowski, quando ele afirma que em toda cultura "(...) cada costume, cada objeto, cada ideia e cada crença exercem uma certa função vital, tem uma certa tarefa a realizar, representam uma parte insubstituível da totalidade orgânica." (MALINOWSKI apud CUCHE, 2002, p. 71).

Daí se entender a importância desse processo para a essência identitária brasileira na contemporaneidade e o quanto ele está para além da ideia de "periferia" e "centro", pois brincar não deve deixar de compor a essência do pensamento infantil sob nenhum pretexto, independentemente das condições socioculturais nas quais a criança esteja inserida. E num país tão desigual quanto o nosso nada mais democrático do que a liberdade proporcionada pela palavra, especialmente quando se trata da magia que pode ser proporcionada pela palavra poética.

\footnotetext{
${ }^{61}$ Cora Coralina. Vintém de Cobre: meias confissões de Aninha. - 10ª edição - São Paulo: Global, 2013, p. 114-121.

${ }^{62}$ Manoel de Barros. Memórias inventadas: as infâncias de Manoel de Barros. São Paulo: Editora Planeta do Brasil, página 134, 2008.
} 
A relevância dos elementos observados neste subcapítulo se dá entendendose que a "(...) civilização de um povo não é nada além de um conjunto de seus fenômenos sociais; e falar de povos incultos, 'sem civilização', de povos 'naturais' (...), é falar de coisas que não existem." (DURKHEIM, apud CUCHE, 2002, p. 53). Por isso as questões já ressaltadas são consideradas caras à formação cultural brasileira, constituindo assim sua essência identitária.

Tais questões, poeticamente construídas, desenham imagens capazes de ocupar um espaço central, mais do que isso, essencial no imaginário do leitor. Isso porque

Se no fim do trajeto a imagem parece ter ultrapassado o discurso, a transcendência se fez também em sentido contrário: para levar a figura à plenitude, foi necessário desatar a corrente das palavras. Goethe: "a ideia, na imagem, permanece infinitamente ativa e exurível."

A realidade da imagem está no ícone. A verdade da imagem está no símbolo verbal. (BOSI, 1977, p. 35-36)

A relação ancestral com a terra; a necessidade de haver amor, empatia e acolhimento entre adulto e criança; a vocação imanente da criança de converter quaisquer situações em brincadeiras, metaforizadas poeticamente na literatura de Cora Coralina e Manoel de Barros a partir de aspectos intrinsecamente ligados a uma vivência, ao mesmo tempo distante das questões tecnológicas da contemporaneidade, mas próximas das questões que ainda compõem o cenário sociocultural dos interiores do Brasil, tocam o leitor de modo não apenas simbiótico, mas, sobretudo, poético.

Entende-se ainda ser esse um processo fundamental para que o leitor possa, em contato com as obras coralineana e manoelina, (re)conhecer em seu interior a essência identitária brasileira, fortalecendo assim sua capacidade de vislumbrar nos elementos suscitados pelos poemas de Cora Coralina e Manoel de Barros parte consubstancial da infância do seu próprio povo, independentemente de implicações sociológicas, culturais, ou mesmo geográficas de periferia e de centro.

Acredita-se que tal fenômeno provocado pela potência do texto poético contribua grandemente para que ele - leitor - possa reconhecer em si mesmo a identidade cultural do povo brasileiro que, embora plural, miscigenada, possui uma essência, no entanto sem se esquecer de que é "(...) semelhante aos outros precisamente pelo seu alto grau de diferenciação. É isto que the permite atribuir a si mesmo "uma identidade humana" e, consequentemente, também uma identidade pessoal." (DEVEREUX, 1972, p. 162-163, apud CUCHE, 1999, p. 191-192). 


\section{CONSIDERAÇÕES FINAIS}

...aquilo que nos mostra o poema não vemos com nossos olhos da matéria, e sim com os do espírito. A poesia nos faz tocar o impalpável e escutar a maré do silêncio cobrindo uma paisagem devastada pela insônia. O testemunho poético nos revela outro mundo dentro deste, o mundo outro que é este mundo. Os sentidos, sem perder seus poderes, convertem-se em servidores da imaginação e nos fazem ouvir o inaudito e ver o imperceptível.

Octavio Paz, in O Arco e a Lira. São Paulo: Cosac Naify, página 11, 2012.

Há um caráter indelével nas sensações, percepções e experimentações da infância. Muitas vezes impossível de ser abarcado pelas palavras. Sabores, aromas, texturas, vozes, imagens compõem o tecido da memória e, ainda que permaneçam trancafiados por toda vida no baú do imaginário, formam as raízes do indivíduo, acompanhando-o pelo decurso de toda a vida.

Ao longo desta tese, procurou-se demonstrar o quanto pode ser despertado no leitor, por meio das literaturas de Cora Coralina e de Manoel de Barros a necessidade de "(...) aspirarmos a viver o estado poético e assim evitar que o estado prosaico engula nossas vidas, necessariamente tecidas em prosa e poesia." (MORIN, 2008, p. 10).

Além disso, acredita-se que, à medida que o leitor experimenta desse "estado poético", ele projeta simbolicamente tanto a cozinha de Cora Coralina quanto o quintal de Manoel de Barros, fortalecendo assim a manifestação do tesouro que reside na composição do imaginário dos interiores do Brasil, entendendo que o imaginário

(...) refere-se a uma produção de caráter histórico que nada mais é do que um conjunto de símbolos, dotados de expressão e conteúdo, que são utilizados pelas sociedades para que as ideologias e culturas a elas subjacentes sejam transferidas de geração a geração. (GREGORIN FILHO, 2011, p. 54)

Vale ressaltar ainda que, sob esse prisma, desaparecem quaisquer diferenciações reducionistas, ou seja, não se trata apenas do que proporciona a obra de Cora Coralina e de Manoel de Barros, mas a literatura infantil e juvenil a qual, como já definira Nelly Novaes Coelho (1982): 
(...) é, antes de tudo, literatura; ou melhor, é arte: fenômeno de criatividade que representa o mundo, o homem, a vida, através da palavra. Funde os sonhos e a vida prática, o imaginário e o real, os ideais e sua possível/impossível realização (p. 27)

Realçadas tais questões, não se pode deixar de considerar aspectos próprios da sociedade contemporânea, especificidades que não podem ser obliteradas. Por exemplo, neste início de século XXI,

(...) pode-se encontrar uma grande variedade de "infâncias" coexistindo nas mais diversas sociedades, desde aquelas que ainda não conhecem as transformações sofridas pela escola e seguem trabalhando como adultos, até aquelas que vivem imersas num mundo puramente tecnológico, também afastadas das atividades lúdicas tão necessárias ao desenvolvimento do ser humano. (GREGORIN FILHO, 2009, p. 42)

De qualquer forma, independentemente da "infância" à qual a criança pertença, é fundamental que seu imaginário seja um espaço de plenitude da liberdade que possibilite a ela enfrentar dragões, salvar o mundo, conquistar reinos, encontrar seus príncipes e princesas encantados, brincar em total comunhão com a natureza e o cosmos. Muitos dos sonhos da infância tornam-se alimento para a vida adulta.

Com base nisso, procura-se demonstrar ao longo desta tese que, do dialogismo entre a poesia de Cora Coralina e a de Manoel de Barros, eclodem imagens capazes de abarcar metaforicamente, de modo simultâneo, esses dois elementos, ainda que sejam paradoxais, compondo poeticamente o amálgama do imaginário cultural e identitário do Brasil.

Tal fato potencializa a relevância das obras desses autores não só na composição da história da literatura brasileira, mas, sobretudo, para a dinâmica do processo de formação de leitores no país os quais, por meio delas, têm a oportunidade de experimentar estética e poeticamente elementos artísticos literários que remetem a um Brasil obliterado durante séculos, ora pelo fomento de uma visão popular reducionista, ora pelas instituições formais de educação que, como já se mencionou, privilegiou apenas o viés colonizador lusitano em detrimento de nossas raízes nativas e africanas.

O dialogismo entre a poética de Cora Coralina e Manoel Barros, ao resgatar aspectos ancestrais e contemporâneos ao mesmo tempo, denota a beleza que 
reside na simplicidade de um Brasil profundo, visceralmente ligado às suas raízes orgânicas a ponto de extrair delas o alimento para as asas do imaginário.

Como o "eu" poético em O Prato Azul-Pombinho que, mesmo mergulhado em suas raízes familiares patriarcais, valia-se da arte que emanava delas - as histórias da bisavó - para libertar as asas de sua imaginação e viajar. Ou ainda, como o "eu" poético em Memórias Inventadas que, estando em um lugar regido pela ausência de "aventuras", recorria a sua relação com a natureza para transformar o cenário de inércia em uma atmosfera repleta de fantasia.

Ao resgatar a suposta simplicidade que reside na essência cultural e identitária brasileira, o dialogismo entre Cora Coralina e Manoel de Barros reverbera, não apenas ancestralidade ou contemporaneidade como evidenciado no capítulo III, mas, sobretudo, atemporalidade, uma vez que, dialogando com o pensamento de Tzvetan Todorov, entende-se que

\begin{abstract}
O belo conduzirá ao verdadeiro e ao bem, e o contato habitual com a arte terá ensinado aos homens a liberdade como igualdade, porque todos são iguais diante da beleza e podem participar dela nas mesmas condições. "Somente as relações fundadas sobre a beleza unem a sociedade, porque elas se relacionam àquilo que é comum a todos." A beleza não conhece privilégios sociais e nem de classe. "No Estado estético, todo mundo, mesmo o trabalhador que é um mero instrumento, é um cidadão livre cujos direitos são iguais aos do mais alto nobre." (TODOROV, 2011, p. 270)
\end{abstract}

Dessa forma, após se abordar a "cozinha" na literatura de Cora Coralina e o "quintal" na literatura de Manoel de Barros nos capítulos I e II respectivamente, conciliando-os à essência identitária brasileira no capítulo III, considera-se agora o momento para realçar a "escrivaninha", e, por meio dela, o elemento humano que decorre do fazer poético propriamente dito em Cora Coralina e Manoel de Barros.

No século XXI é natural pensar na escrivaninha como um móvel útil apenas para se colocarem os aparelhos digitais, ou livros, ou mesmo quaisquer apetrechos, pois a ideia da escrita manuscrita é vista como algo muito remoto e distante, ancestral. No entanto não podemos negar o caráter humano que dela decorre. $\mathrm{Na}$ biografia de Cora Coralina e Manoel de Barros, a escrivaninha ocupa lugar de destaque, transcendendo seu caráter referencial, metaforizando o fazer poético de ambos.

Diante desse cenário, a metáfora da "escrivaninha" abarca a relação dialógica entre as metáforas da "cozinha" e do "quintal", atribuindo aos poemas concebidos 
nela um caráter essencialmente humano, fundamental para a formação do leitor, pois este, independentemente do tempo a que pertença, deve perceber que o poema “(...) é o que está além da linguagem. Mas isso que está além da linguagem só pode ser alcançado por intermédio da linguagem. Um quadro será poema se for algo mais que linguagem pictória." (PAZ, 2012, p. 31).

Adquirida tal percepção, é possível que o leitor se torne sujeito crítico e criativo, desenvolvendo, por meio do aguçamento de sua sensibilidade e capacidade de observação, habilidades que o permitam lidar melhor até com questões tecnológicas próprias da contemporaneidade na qual ele está inserido.

Mesmo quando se volta aos clássicos, percebe-se que na educação grecoromana - desenvolvida entre os séculos $V$ a. C. e V d. C. e que serviu de base para a educação ocidental - o ensinamento de poesia, dos poemas gregos homéricos da fase heroica aos poemas da fase imperial romana, era desenvolvido com relevância e deferência. Gregos e romanos já consideravam o texto poético um poderoso instrumento, capaz de auxiliar na formação do homem, desde sua mais tenra idade.

Tal modo de conceber educação diz muito a respeito da importância do texto poético para o processo de formação do indivíduo, uma vez que a poesia "é o grau mais alto do pensar." (BRASILEIRO, 2002, p. 151), provavelmente porque já enxergavam a potência (re)criadora da linguagem como característica intrínseca da poesia. Nesse sentido é fundamental pensarmos que o "poema é um ser de linguagem".

A vivacidade imanente ao texto poético torna-o assim imprescindível, para se dizer o mínimo, na formação do homem não apenas para aguçar sua sensibilidade acerca de si mesmo, mas também da sociedade, isso porque o "poema requer uma especificidade e mais trabalho para que se desvendam os seus códigos." (GREGORIN FILHO, 2009, p. 75). E é esse profundo exercício de análise, praticado desde cedo, que permitirá ao indivíduo conceber seu imaginário e, consequentemente, o mundo ao seu redor, de forma mais humana.

Em se tratando da questão dos gêneros literários, não seria incorreto pensar que a poesia extrapola todos os limites, é a expressão máxima da liberdade artística, invade o íntimo do leitor, transportando-o "através da loucura e da sabedoria, e para além delas" (MORIN, 2008, p. 09), fazendo-o transbordar, transcender a si mesmo, e, ainda que num átimo de segundo, ser tomado por sensações que o tornam capaz de experimentar um mundo inédito, onde prevalecem a beleza e o êxtase absolutos. 
Quanto ao poema, pensando estrutural e esteticamente, há uma sensação limítrofe que leva a acreditar em situações fronteiriças, principalmente quando se comparam formas fixas, pertencentes a uma pretensa Tradição, como o soneto, em relação aos poemas concretos, por exemplo, pois são vistas sem muito esforço diferenças claras, podendo ser pontuadas num primeiro olhar.

Entretanto, apesar das diferenças relacionadas à forma, é na presença da poeticidade, percebida por meio das metáforas, dos símbolos, das sinestesias, enfim, de todos os elementos que permitem à linguagem conceber o processo de (re)criação, ou ainda, de (trans)criação, que é possível aos poemas dialogarem entre si.

À medida que a palavra poética rompe com os limites do tempo, da tradição e de tudo aquilo que representa algum espaço fronteiriço, ela nos proporciona uma experiência humana única, a da revelação poética, revelação esta que "sempre desemboca numa criação: a de nós mesmos" (PAZ, 2012, p. 161). Eis o início da construção dos saberes e dos conhecimentos acerca do indivíduo e do mundo.

É na Arte, representada pela palavra poética, e não na Ciência, entendida aqui como conhecimento sistematizado e representada pela palavra organizada de forma lógica, que reside o cerne da construção do conhecimento cultural das civilizações.

A Arte sempre chega primeiro às reflexões mais profundas, àquelas guardadas a sete chaves nas entranhas do homem, ou seja, enquanto Freud, em pleno século XIX, sistematizava a existência do alter ego, Shakespeare, aproximadamente três séculos antes, já colocava Hamlet diante do espelho a questionar: "To be or not to be, that's the question...".

Sob esse aspecto, seja na Antiguidade clássica, seja na Idade Média, seja na contemporaneidade, "a encarnação humana da beleza é a arte; daí resulta que é pela prática das artes que os homens poderão ser educados" (TODOROV, 2011, p. 269). Educação e Arte devem caminhar juntas. Sob esse aspecto, embora se saiba que a literatura não mais se deixa definir por este ou aquele gênero, argumenta-se em favor da poesia, por coadunarmos com o pensamento de Octavio Paz, ao afirmar que

A prosa é um gênero tardio, filho da desconfiança do pensamento ante as tendências naturais do idioma. A poesia pertence a todas as épocas: é a forma natural de expressão dos homens. Não há povos sem poesia, mas 
existem os que não têm prosa. (...) A poesia ignora o progresso ou a evolução e suas origens e seu fim se confundem com os da linguagem. (PAZ, 2006, p. 12)

A relevância de tais aspectos da palavra poética reside no fato de que as crianças “(...) amam as palavras por sua própria sonoridade e ritmo, como se através desse convívio lúdico com elas, inconscientemente (...) estabelecesse uma ligação obscura com algo importante que (...) engloba e transcende." (Coelho, 1982, p. 148).

Por tais razões, acredita-se ser fundamental oferecer à criança e ao jovem uma poesia cuja literatura, cozida no fogo e lavrada na terra, possa servir como alimento, diversão, despertar das reminiscências de outrora, arrebatando-os e transcendendo-os através da palavra artesanal que proporciona o "Regresso à infância" mencionado por Octavio Paz.

Quando se pensa na dinâmica da educação formal na contemporaneidade, tem-se, no caso do Brasil, a Base Nacional Comum Curricular (BNCC) ${ }^{63}$, que é o documento responsável por definir o conjunto de aprendizagens essenciais. Nela, privilegiam-se aspectos lúdicos relacionados às palavras, desde a mais tenra idade.

$\mathrm{Na}$ "Introdução" da BNCC, por exemplo, no quadro que trata das "Competências Gerais da Educação Básica", o item número 9 explicita a importância de:

Exercitar a empatia, o diálogo, a resolução de conflitos e a cooperação, fazendo-se respeitar e promovendo o respeito ao outro e aos direitos humanos, com acolhimento e valorização da diversidade de indivíduos e de grupos sociais, seus saberes, identidades, culturas e potencialidades, sem preconceitos de qualquer natureza. ${ }^{64}$

E de modo mais específico, no item número 4 - Etapa do Ensino Fundamental -, mais especificamente, no subitem 4.1 - A Área de Linguagens -, ao

${ }^{63}$ A Base Nacional Comum Curricular (BNCC) é um documento de caráter normativo que define o conjunto orgânico e progressivo de aprendizagens essenciais que todos os alunos devem desenvolver ao longo das etapas e modalidades da Educação Básica, de modo que tenham assegurados seus direitos de aprendizagem e desenvolvimento, em conformidade com 0 que preceitua o Plano Nacional da Educação (PNE). Este documento normativo aplica-se exclusivamente à educação escolar, tal como a define $0 \S 1^{\circ}$ do Artigo $1^{\circ}$ da Lei de Diretrizes e Bases da Educação Nacional (LDB, Lei oํ 9.394/1996), e está orientado pelos princípios éticos, políticos e estéticos que visam à formação humana integral e à construção de uma sociedade justa, democrática e inclusiva, como fundamentado nas Diretrizes Curriculares Nacionais da Educação (DCN). (...). Introdução. Consultado no site www.basenacionalcomum.mec.gov.br, acesso no dia 17 de novembro de 2019, às 18h:00;

${ }^{64}$ Acessado no site http://basenacionalcomum.mec.gov.br/abase/\#introducao no dia 19/11/2019, às 13h:00. 
abordar as "Competências Específicas de Linguagens para o Ensino Fundamental", o documento esclarece a necessidade de desenvolver na criança o

(...) o senso estético para reconhecer, fruir e respeitar as diversas manifestações artísticas e culturais, das locais às mundiais, inclusive aquelas pertencentes ao patrimônio cultural da humanidade, bem como participar de práticas diversificadas, individuais e coletivas, da produção artístico-cultural, com respeito à diversidade de saberes, identidades e culturas. $^{65}$

Orienta-se, por exemplo, que os alunos, dos 4 aos 5 anos e 11 meses de idade sejam incentivados à habilidade de "Inventar brincadeiras cantadas, poemas e canções, criando rimas, aliterações e ritmos ${ }^{66 "}$.

Os exemplos de competências supracitados propostos pela BNCC dialogam profundamente com aspectos fulcrais sob os quais a poesia de Cora Coralina e Manoel de Barros são construídas, visto que o universo poético de ambos projeta a infância, acima de tudo, como espaço do brincar. Além disso, para finalizar a questão da aprendizagem do ponto de vista formal, vale ressaltar ainda que tanto a obra da rapsoda goiana quanto do poeta mato-grossense atendem grandemente à metodologia proposta por Tzvetan Todorov. Para ele, a

(...) análise feita na escola não deveria mais ter por objetivo ilustrar os conceitos recém-introduzidos por este ou aquele linguista, este ou aquele teórico da literatura, quando, então, os textos são apresentados como uma aplicação da língua e do discurso; sua tarefa deveria ser a de nos fazer ter acesso ao sentido dessas obras - pois postulamos que esse sentido, por sua vez, nos conduz a um conhecimento do humano, o qual importa a todos. (TODOROV, 2010, p. 89)

Dessa forma, tomando por base as questões supracitadas, embora se tenha afirmado no primeiro parágrafo que há circunstâncias impossíveis de serem abarcadas pelas palavras, entende-se que as que são possíveis, só são por meio da palavra poética, como sinalizava Paul Valèry. Segundo ele:

... entre todas as artes, a nossa é talvez a que coordena o máximo de partes ou de fatores independentes: o som, o sentido, o real, o imaginário, a

\footnotetext{
${ }^{65}$ Acessado no site http://basenacionalcomum.mec.gov.br/abase/\#fundamental/a-area-de-linguagens no dia 19/11/2019, às 13h:10.

${ }^{66}$ Consultado no site www.basenacionalcomum.mec.gov.br, acesso no dia 17 de novembro de 2019, às 18h:10; no item 3. A etapa da Educação Infantil, quadro de "Objetivos de aprendizagem e desenvolvimento"; coluna referente às Crianças pequenas (4 anos a 5 anos e 11 meses); Habilidade EI03EF02: Inventar brincadeiras cantadas, poemas e canções, criando rimas, aliterações e ritmos.
} 
lógica, a sintaxe e a dupla invenção do conteúdo e da forma... e tudo isso por intermédio desse meio essencialmente prático, perpetuamente alterado, profanado, desempenhando todos os ofícios, a linguagem comum, da qual devemos tirar uma Voz pura, ideal, capaz de comunicar sem fraquezas, sem aparente esforço, sem atentado ao ouvido e sem romper a esfera instantânea do universo poético, uma ideia de algum eu maravilhosamente superior a Mim. (VALÈRY, 1999, p. 210)

Nesse contexto, defende-se que das escrivaninhas de Cora Coralina e Manoel de Barros emerge uma linguagem poética cuja composição verbal desenha uma infância repleta de experiências que mesclam dificuldades e belezas de seu tempo, compondo poeticamente um Brasil profundo no qual, apesar da significativa escassez de recursos, tudo se metamorfoseava em brincadeira, preenchendo o imaginário do leitor com circunstâncias cujas

(...) experiências não se confundem entre si, porém todas conduzem a um estado de plenitude, nos dão um sentimento de realização interior. Sensação fugaz e ao mesmo tempo infinitamente desejável, pois graças a ela nossa existência não decorre em vão; graças a esses momentos preciosos, ela se torna mais bela e mais rica de sentidos. (TODOROV, 2011, p. 09)

Entende-se ainda que no dialogismo entre ambos é possível resgatar muito mais do que uma literatura memorialística, biográfica, esteticamente construída privilegiando a poesia - ainda que possua elementos da prosa. Há nela uma poeticidade imanente à linguagem capaz de remeter não apenas a uma experiência de infância subjacente aos interiores do país, mas, sobretudo, a uma experiência de infância poética única.

Entretanto sabe-se bem que, embora não possamos “(...) viver permanentemente nesse estado de realização e de plenitude do ser, que se trata mais de um horizonte do que de um território; sem ele, todavia, a vida não tem o mesmo valor." (TODOROV, 2011, p. 10). Daí considerar indispensáveis os elementos suscitados pelas obras poéticas de Cora Coralina e Manoel de Barros, especialmente numa sociedade contemporânea que parece, em função das questões voltadas para as tecnologias, dispersar elementos ligados à cultura.

Assim, a escrivaninha simboliza o lugar mágico de onde os poetas fazem ecoar uma infância cuja essência, repleta de ancestralidade, vai para além das questões que envolvem periferia e centro na concepção das dinâmicas sociológica, cultural e identitária brasileiras ao longo da história, proporcionando ao leitor 
percepções que independem de sua vivência, não apenas imersos num mundo de tecnologias e sem lugar para reflexão, pois:

A civilização dita tecnológica ou pós-industrial está em vias de sufocar em todo o mundo o que subsiste das outras culturas e de nos impor o modelo de uma brutal sociedade de consumo. (ZUMTHOR, 2014, p. 63)

Enfim, da dialógica entre a poesia de Cora Coralina e Manoel de Barros brota uma linguagem poética que, sem ignorar as agruras de uma infância típica dos interiores do país, privilegia a fantasia, a magia, as brincadeiras, compondo um universo poético em cuja infância, repleta de empatia e acolhimento, só tem espaço para o mais humano dos sentimentos: o amor.

Sabe-se que não é nova a relação entre poesia e amor, entende-se inclusive que o "(...) amor faz parte da poesia da vida. A poesia faz parte do amor da vida. Amor e poesia engendram-se mutuamente e podem identificar-se um com o outro" (MORIN, 2008, p. 09). No entanto, especialmente quando se trata da infância, infelizmente não é incomum se ver a ausência dessas duas instâncias, seja na relação com os adultos em casa, seja na escola, ou mesmo na sociedade.

Nesse cenário, é fundamental a presença da literatura, pois sendo "o objeto da literatura a própria condição humana, aquele que a lê e a compreende se tornará não um especialista em análise literária, mas um conhecedor do ser humano." (TODOROV, 2010, p. 92-93). A poesia de Cora Coralina e Manoel de Barros nos ensina que nada é mais humano para a criança do que a capacidade que ela tem de estar em comunhão com o mundo a sua volta, pois a despeito de quaisquer adversidades, o imaginário se configura como espaço de plenitude, liberdade e harmonia.

Sob tal aspecto é que se defende a necessidade absoluta da presença de uma literatura, cuja poeticidade seja capaz de proporcionar ao leitor a possibilidade de vislumbrar um mundo onde a criança possa ter, em suas próprias escrivaninhas, liberdade de leitura e criação. Liberdade do contato com aquilo que há de mais profundo na cultura brasileira, não apenas aquilo que foi burocratizado como cânone na escrivaninha de fazedores de leis pedagógicas que, muitas vezes, apenas reproduzem a arte e o fazer de culturas alheias e muito distantes da genuinamente brasileira. 
Não se está aqui levantando a bandeira de um nacionalismo desmedido ou de um ufanismo tardio; o que se pretende é dar voz à arte daqueles muitas vezes marginalizados pelo pensamento intelectual e pelos currículos escolares, marginalização essa que muitas vezes começa na educação infantil e continua até os bancos universitários. 


\section{BIBLIOGRAFIA}

AGAMBEN, Giorgio. O que é o contemporâneo? E outros ensaios. Trad. de Vinícius Nicastro Honesko. Chapecó, Argos, 2009.

ALMEIDA, Nilma Figueiredo de. "O imaginário na psicologia analítica de C.G. Jung". In Introdução aos Pensadores do Imaginário. Nyrma Souza Nunes de Azevedo e Reuber Gerbassi Scofano (Organizadores). Campinas, SP: Editora Alínea, 2018.

A vitória de Cora. Revista Análise, Goiânia, n. 6, maio de 1984.

BAKHTIN, Mikhail. Estética da Criação Verbal; Introdução e Trad. do russo Paulo Bezerra. - 5aㅡ edição. - São Paulo: Editora WMF Martins Fontes, 2010.

BARROS, Manoel de. O livro das ignorãças. - 5ª Edição - Rio de Janeiro: Record, 1998.

Livro sobre Nada. - 9ª Edição - Rio de Janeiro: Record, 2001.

Memórias Inventadas: as infâncias de Manoel de Barros. São Paulo: Editora Planeta do Brasil, 2008.

Menino do Mato. São Paulo: Leya, 2010.

BARTHES, Roland. O grau zero da escritura. Tradução de Anne Arnichand e Álvaro Lorencini. São Paulo: Editora Cultrix, 1971.

BÉDA, W. G. A construção poética de si mesmo: Manoel de Barros e a autobiografia. Assis, 2007. 153 p. Tese (Doutorado) - Faculdade de Ciências e Letras de Assis, Universidade Estadual Paulista.

BENJAMIM, Walter. Magia e técnica, arte e política: ensaios sobre literatura e história da cultura. Trad. Sergio Paulo Rouanet. São Paulo: Brasiliense, 1985. 
BERGSON, Henri. Memória e Vida; textos escolhidos por Gilles Deleuze. Trad. de Claudia Berliner. São Paulo: Martins Fontes, 2006.

BLANCHOT, Maurice. O espaço literário. Trad. de Álvaro Cabral. Rio de Janeiro. Editora: Rocco, 1987.

BRASILEIRO, Antonio. Da inutilidade da Poesia / Antonio Brasileiro. Salvador: EDUFBA, 2002.

BRITTO, Clóvis Carvalho. Sou Paraíba pra cá: literatura e sociedade em Cora Coralina. Dissertação de Mestrado. Goiânia, UFG, 2006, 190 p.

BRITTO, Clóvis Carvalho; SEDA, Rita Elisa. Cora Coralina: raízes de Aninha. 6 edição. Aparecida-SP: Ideias \& Letras, 2009.

BORDINI, Maria da Glória. "Pensando a poesia infantil de agora." In: ZILBERMANN, R.; RÖSING, T. M. K. (Orgs.). Escola e leitura: velha crise, novas alternativas. São Paulo: Global, 2009, p. 139-159. (Coleção Leitura e Formação).

BOSI, Alfredo, 1936 -. O ser e o tempo da poesia. São Paulo, Cultrix,. Ed. da Universidade de São Paulo, 1977.

BOTASSI, Miriam. Cora Coralina conta um pouco da sua história. Mulherio, jul. 1983.

CALVINO, Ítalo. Seis propostas para o próximo milênio. 1a edição. Trad. de Ivo Barroso. São Paulo: Companhia das Letras, 1990.

CAMARGO, Goiandira Ortiz de. Cora Coralina: uma poética para todas as vidas. In DENÓFRIO, Darcy França; CAMARGO, Goiandira Ortiz de (Orgs.). Cora Coralina: celebração de volta. Goiânia: Cânone, 2006.

CAMPOS, Haroldo de. Metalinguagem \& Outras Metas. São Paulo, Editora Perspectiva, 2006. 
CANDIDO, Antonio. Literatura e Sociedade: estudos de teoria e história literária / Antonio Cândido. 7ª edição. São Paulo: Editora Nacional, 1985.

Vários Escritos. São Paulo / Rio de Janeiro: Duas Cidades / Ouro sobre Azul, 2004.

O estudo analítico do poema. 5a edição - São Paulo: Associação Editorial Humanitas, 2006.

Cântico de Andradina: imortal herança de Cora Coralina. O Jornal da Região, Andradina, 12 de abril de 1985.

CHEVALIER, Jean / GHEERBRANT, Alain, 1906 - Dicionário de Símbolos: (mitos, sonhos, costumes, gestos, formas, figuras, cores, números) / Jean Chevalier, Alain Gheerbrant, com a colaboração de André Barbault... [et al.]; coord. de Carlos Sussekind; trad. de Vera da Costa e Silva... [et al.]. 21ํㅡㄹ ed. Rio de Janeiro: José Olympio, 2007.

COELHO, Nelly Novaes. A Literatura infantil: História - Teoria - Análise. São Paulo: Global, 1982.

COLOMER, Teresa. A formação do leitor literário: narrativa infantil e juvenil atual / Teresa Colomer; tradução Laura Sandroni. - São Paulo: Global, 2003.

CORALINA, Cora, 1889 - 1985. Melhores poemas / Cora Coralina; seleção e apresentação Darcy França Denófrio. $3^{\text {a }}$ edição revista e ampliada - São Paulo: Global, 2008. - (Coleção Melhores poemas / direção Edla van Steen)

. Poemas dos becos de Goiás e estórias mais / Cora Coralina. - 23a edição São Paulo: Global, 2014. 238 p. 
. O Prato-Azul Pombinho / Cora Coralina; ilustrações Lúcia Hiratsuka. - 4ª ed. - São Paulo: Global, 2011. 3ํㅡㄹ reimpressão, 2015.

Poema do Milho / Cora Coralina; ilustrações Lélis. - 3a ed. - São Paulo: Global, 2011. 2ª reimpressão, 2015.

Os meninos Verdes / Cora Coralina; ilustrações de Gepp e Maia. - 1ª ed. São Paulo: Global, 1986.

Os Meninos Verdes / Cora Coralina; ilustrações de Cláudia Scatamacchia. 12aㅡ ed. - São Paulo: Global 2007. 7ª reimpressão, 2017.

COUTINHO, Afrânio. Notas de Teoria Literária. Civilização Brasileira, Rio de Janeiro, 1976.

GRANATO, T. A. C. Educação em questão. Petrópolis: Vozes, 2000.

GREGORIN FILHO, José Nicolau. Literatura infantil: múltiplas linguagens na formação de leitores. São Paulo: Editora Melhoramentos, 2009.

. Literatura juvenil: adolescência, cultura e formação de leitores. São Paulo: Editora Melhoramentos, 2011.

HEIDEGGER, Martin. Conferências e escritos filosóficos. São Paulo: Abril, 1979. (Os pensadores)

JUNG, C. G. O homem à descoberta de sua alma. Porto, Portugal: Tavares Martins, 1962.

Os arquétipos e o inconsciente coletivo. Petrópolis, RJ: Vozes, 2000. (Obras completas de C. G. Jung; v. 9/1)

MAGNANI, Maria do Rosário Mortatti. Leitura, Literatura e Escola. 2ª Edição - São Paulo: Martins Fontes, 2001. 
MARTHA, Alice Áurea Penteado. "Pequena prosa sobre versos". In Poesia infantil e juvenil brasileira: uma ciranda sem fim / Vera Teixeira de Aguiar, João Luís Ceccantini, (organizadores). - São Paulo: Cultura Acadêmica, 2012.

MORIN, Edgar. Amor, poesia, sabedoria; tradução de Edgard de Assis Carvalho. 8a edição - Rio de Janeiro: Bertrand Brasil, 2008.

PALO, M. J. G.; OLIVEIRA, Maria Rosa Duarte de. Literatura Infantil: Voz de Criança. 4ª . ed. São Paulo: Ática, 1986.

PAZ, Octavio. O Arco e a Lira. Tradução Ari Roitman e Paulina Wacht. São Paulo: Cosac Naify, 2012.

A Outra Voz. Trad. de Wladir Dupont. São Paulo:Editora Siciliano, 1993.

Signos em rotação. Tradução Sebastião Uchôa Leite; organização e revisão Celso Lafer e Haroldo de Campos. São Paulo: Perspectiva, 2006.

PAZ, Ravel Giordano. D. Cora, a mucilagem e a herança das (outras) cores: infância e política em Os Meninos Verdes (e seus ilustradores). Revista Cerrados (Brasília. Online), v. 25, p. 356-380, 2016.

PIGNATARI, Décio. O que é comunicação poética / Décio Pignatari. - $8^{a}$ edição Coti, SP: Ateliê Editorial, 2005.

SCOFANO, Reuber Gerbassi. "A imaginação em Gaston Bachelard". In Introdução aos Pensadores do Imaginário. Nyrma Souza Nunes de Azevedo e Reuber Gerbassi Scofano (Organizadores). Campinas, SP: Editora Alínea, 2018.

SCOFANO, Reuber Gerbassi; MAIA, Maria Vitória Campos Mamede. "Gilbert Duran e a imaginação simbólica". In Introdução aos Pensadores do Imaginário. Nyrma Souza Nunes de Azevedo e Reuber Gerbassi Scofano (Organizadores). Campinas, SP: Editora Alínea, 2018. 
SILVA, Kelcilene Grácia da. A poética de Manoel de Barros: um jeito de olhar o mundo. 1998. 243f. Dissertação (Mestrado em Letras) - Faculdade de Ciências e Letras de Assis, Universidade Estadual Paulista Júlio de Mesquita Filho.

TODOROV, Tzvetan. A Literatura em perigo / Tzvetan Todorov; tradução Caio Meira. 3aㅡ edição. Rio de Janeiro: DIFEL, 2010.

A Beleza salvará o mundo: Wilde, Rilke e Tsvetaeva: os aventureiros do absoluto / Tzvetan Todorov; tradução Caio Meira. Rio de Janeiro: DIFEL, 2011. . Introdução à Literatura Fantástica. São Paulo: Perspectiva, 2007.

VALÉRY, Paul. Variedades. Trad. de Maiza Martins. Org. int. de João Alexandre Barbosa. São Paulo. Editora lluminuras, 1999.

ZUMTHOR, Paul. Performance, recepção, leitura. Tradução de Jerusa Pires Ferreira e Suely Fenerich. São Paulo: Cosac Naify, 2014. 
APÊNDICES 


\section{Apêndice A: \\ Dissertações e Teses sobre Cora Coralina}

BRITTO, Clovis Carvalho. "Sou Paranaíba pra cá": literatura e sociedade em Cora Coralina. Dissertação (Mestrado em Sociologia) - Faculdade de Ciências Sociais, Universidade Federal de Goiás, 2006.

CAETANO, Maria de Lourdes Jacinto. A Natureza na Literatura de Cora Coralina: a poética do contexto e lugar. Dissertação (Mestrado em Educação Ambiental) Unievangélica - Centro Universitário de Anápolis Programa de Pós-Graduação em Sociedade, Tecnologia e Meio Ambiente - Centro Universitário de Anápolis, Goiás, 2015.

DELGADO, Andrea Ferreira. A invenção de Cora Coralina na batalha das memórias. Tese (Doutorado) - Universidade Estadual de Campinas, Instituto de Filosofia e Ciências Humanas, Campinas, São Paulo, p. 498. 2003.

DIAS, Paula Pinho. Sociedade, cognição e discurso: desvendando Cora Coralina. Dissertação (Mestrado em Língua Portuguesa) - Programa de Estudos Pós-Graduados em Língua Portuguesa, Pontifícia Universidade Católica de São Paulo. São Paulo, p. 301. 2008.

FÉLIX, Pabrícia Abadia Pereira. A mulher no discurso de Cora Coralina: uma análise do sistema de Avaliatividade / Pabrícia Abadia Pereira Félix, Fabíola Aparecida Sartin Dutra Parreira Almeida. Dissertação (Mestrado) - Universidade Federal de Goiás, Unidade Acadêmica Especial de Letras e Linguística, Programa de Pós-Graduação em Estudos da Linguagem, Catalão, Goiás, p. 124. 2019.

GOMES, Melissa Carvalho. No rastro de Cora: da literatura ao desenvolvimento local, identidade e cultura com açúcar e literatura. Dissertação (Mestrado em Serviço Social) - Departamento de Serviço Social, Pontifícia Universidade Católica do Rio de Janeiro, 2004. 
GRANTS, Andréa Figueiredo Leão. (Des)arquivar biografemas: a biblioteca de Cora Coralina. Tese (Doutorado em Literatura) - Universidade Federal de Santa Catarina, Centro de Comunicação e Expressão. Programa de Pós-Graduação em Literatura. Florianópolis, Santa Catarina, p. 459. 2016.

MORAGAS, Rosana Alves Ribas. O (re)significar o lugar no ensino de geografia em Goiás: por meio da poesia de Cora Coralina. Tese (Doutorado em Geografia Humana) - Faculdade de Filosofia, Letras e Ciências Humanas, Universidade de São Paulo. São Paulo, p. 148. 2017.

OLIVEIRA, Márcia Batista de. Cora Coralina: cartografias da memória. Dissertação (Mestrado em Língua Portuguesa) - Universidade Estadual de Londrina, Programa de Pós-Graduação em Letras, Londrina, Paraná, p. 148. 2006.

PEREIRA, lêda Maria Vilas Bôas Pereira. A Mulher-Poeta e suas múltiplas vozes. Dissertação (Mestrado em Literatura) - Universidade de Brasília, Instituto de Letras - Departamento de Teoria Literária e Literaturas - Programa de Pós-graduação em Literatura, Brasília, Goiás, p. 130. 2009.

SANTOS, Jana Cândida Castro dos. Cidade e representação: a cidade de Goiás na obra de Cora Coralina. Dissertação (Mestrado em Arquitetura e Urbanismo) Universidade de Brasília, Brasília, p. 178. 2017.

VELLASCO, Marlene Gomes de. A poética da reminiscência: estudos sobre Cora Coralina. Dissertação (Mestrado em Literatura) - Faculdade de Letras, Universidade Federal de Goiás, 1990. 
Apêndice B:

Dissertações e Teses sobre Manoel de Barros ${ }^{67}$

BASEIO, Maria Auxiliadora Fontana. Entre a magia da voz e a artesania da letra: o sagrado em Manoel de Barros e Mia Couto. Tese (Doutorado em Estudos Comparados de Literaturas de Língua Portuguesa) - Faculdade de Filosofia, Letras e Ciências Humanas, Universidade de São Paulo, 2007.

CAMPOS, Maria Cristina de Aguiar. Manoel de Barros: o demiurgo das terras encharcadas - educação pela vivência do chão. Tese (Doutorado em Educação) Faculdade de Educação, Universidade de São Paulo, 2007.

CASTRO, Miraci Tamara. A canoa da escritura formativa: trajetórias do barro pelo rio ao mar. Dissertação (Mestrado em Educação) - Faculdade de Educação, Universidade de São Paulo. São Paulo, 2015.

GALHARTE, Julio Augusto Xavier. Despalavras de efeito: os silêncios na obra de Manoel de Barros. Tese (Doutorado em Teoria Literária e Literatura Comparada) Faculdade de Filosofia, Letras e Ciências Humanas, Universidade de São Paulo, 2007.

LIMA, Marinei Almeida. Entre vôos, pântanos e ilhas: um estudo comparado entre Manoel de Barros e Eduardo White. Tese (Doutorado em Estudos Comparados de Literaturas de Língua Portuguesa) - Faculdade de Filosofia, Letras e Ciências Humanas, Universidade de São Paulo, 2008.

MAIA, Mara Jane Sousa. Tecendo o estético e o sensível através do bordado na literatura infantil brasileira. Dissertação (Mestrado em Semiótica e Linguística Geral) - Faculdade de Filosofia, Letras e Ciências Humanas, Universidade de São Paulo, 2010.

\footnotetext{
${ }^{67}$ Ressalta-se que constam apenas pesquisas feitas na Universidade de São Paulo, porque o objetivo deste anexo é apenas ilustrar o quanto a pesquisa acerca da obra de Manoel de Barros é mais vasta do que a de Cora Coralina.
} 
PINHEIRO, Carlos Eduardo Brefore. Entre o ínfimo e o grandioso, entre o passado e o presente: o jogo dialético da poética de Manoel de Barros. Tese (Doutorado em Teoria Literária e Literatura Comparada) - Faculdade de Filosofia, Letras e Ciências Humanas, Universidade de São Paulo, 2011.

REINER, Nery Nice Biancalana. A poética de Manoel de Barros e a relação homem-vegetal. Tese (Doutorado em Estudos Comparados de Literaturas de Língua Portuguesa) - Faculdade de Filosofia, Letras e Ciências Humanas, Universidade de São Paulo, 2007.

SANTOS, Julia de Andrade Henrique dos. Quando a dança encontra a criança: um estudo acerca da criação em dança contemporânea para criança. Dissertação (Mestrado em Estética e História das Arte) - Interunidades em Estética e História da Arte, Universidade de São Paulo, 2017.

SOUZA, Jussara Brito de. A expressividade de prefixos e sufixos: uma proposta didática. Dissertação (Mestrado Profissional em Letras em Rede Nacional) Faculdade de Filosofia, Letras e Ciências Humanas, Universidade de São Paulo, 2016. 
ANEXOS 


\section{Anexo l:}

\section{Estória do Aparelho Azul-Pombinho}

Minha bisavó - que Deus a tenha em bom lugar inspirada no passado sempre tinha o que contar.

Velhas tradições. Casos de assombração.

Costumes antigos. Usanças de outros tempos.

Cenas da escravidão.

Cronologia superada

onde havia banguês.

Mucamas e cadeirinhas.

Rodas e teares. Ouro em profusão, posto a secar em couro de boi.

Crioulinho vigiando de vara na mão

pra galinha não ciscar.

Romanceiro. Estórias avoengas...

Por sinal que uma delas embalou minha infância.

Era a estória de um aparelho de jantar que tinha sido encomendado de Goiás através de uma rede de correspondentes como era norma, naquele tempo.

Encomenda levada numa carta em nobre estilo amistoso-comercial.

Bem notada. Fechada com obreia preta.

Carta que foi entregue de mão própria ao correspondente na Corte que tinha morada e loja de ferragem na Rua do Sabão.

O considerado lusitano - metódico e pontual -, o passou para Lisboa. Lisboa passou para Luanda. 
Luanda no usual

passou para Macau.

Macau se entendeu com mercadores chineses.

E um fabricante-loiceiro, artesão de Cantão, laborou o prodígio (no dizer de minha bisavó).

Um aparelho de jantar - 92 peças.

Enorme. Pesado, lendário.

Pintado, estoriado, versejado, de loiça azul-pombinho.

Encomenda de um senhor cônego de Goiás para o casamento de seu sobrinho e afilhado com uma filha de minha bisavó.

O cônego-tio e padrinho pelo visto, relatado, fazia gosto naquele matrimônio.

E o aparelho era para as bodas contratadas. Um carro de boi 15 juntas, 30 bois bem fornido e rejuntado para viagem longa, partiu de Goiás, no século passado, do meado, pouco mais. Levava seis escravos escolhidos e um feitor de confiança.

Mantimentos para a viagem.

E mais, oitavas de ouro, disfarçadas no fundo de um berrante, para os imprevistos da delonga. 
E o antigo carro

por ano e meio quase

rodou, sulcou, cantou e levantou poeira

rechinando

por caminhos e atalhos,

vilas e cidades, campos, sarobais.

Atravessou rios em balsas.

Vadeou lameiros, tremedais.

Varou Goiás - fim de mundo.

Cortou o sertão de Minas.

O planalto de São Paulo.

Foi receber o aparelho e mais sedas e xailes da índia em Caçapava ponta dos trilhos da Dão Pedro Segundo ali por volta de 1860 e tantos.

Durou essa viagem, ir e voltar, dezesseis meses e vinte e dois dias.

- As bodas em suspenso.

Enquanto se esperava, escravas de dentro fiavam na roda e urdiam no tear.

Mucamas compenetradas, mestreadas por rica-dona, sentadas nas esteiras, nos estrados de costura, desfiavam, bordavam, crivavam, repolegavam o bragal de minha avó.

Sinhazinha de catorze anos - fermosura.

Prendada. Faceira.

Muito certa na Doutrina.

Entendida do governo de uma casa

e analfabeta.

Diziam os antigos educadores:

"- Mulher saber ler e escrever não é virtude". 
Afinal, muito esperado,

chegou a Goiás, sem novidades ou peça quebrada,

o aparelho encomendado

através de uma rede de correspondentes.

Embarcado num veleiro,

no porto de Macau.

As bodas marcadas

se fizeram com aparato.

Fartas comezainas.

Vinho do Espinho - Portugal -

da parte do correspondente.

Aparelhos de loiça da China.

Faqueiros e salvas de prata

Compoteiras e copos de cristal.

Na sobremesa minha bisavó exultava...

Figurava uma pinha de iludição.

Toda ela de cartuchos de papel verde calandrado, cheios de confeitos de ouro em filigrana.

Mimo aos convidados graduados:

Governador da Província.

Cônegos, Monsenhores, Padres-Mestres,

Capitão-Mor.

Brigadeiros. Comendadores.

Juízes e Provedores.

Muita pompa e toda parentela.

Por amor e grandeza desse fasto

- casamento da sinhazinha Honória

com o sinhô-moço Joaquim Luís -

dois velhos escravos, já pintando,

receberam chorando

suas cartas de alforria. 
Ficou mais, assentado e prometido

em palavra de rei testemunhado,

que o crioulinho

que viesse ao mundo

com o primogênito do casal

seria forro sem tardança na pia batismal.

E se criaria em regalia

com o senhorzinho,

nato fosse ele, em hora e dia.

Um rebento do casal veio ao mundo

no fim de nove meses.

e na senzala do quintal

nascia de uma escrava

um crioulinho.

Conforme o prometido - libertado

alforriado

na pia batismal.

(Na pia batismal, era, naquele tempo,

forma legal e usual de se alforriar um escravo).

Toda essa estória

por via de um aparelho de loiça da China,

destinado a Goiás.

Laborado de um oleiro, loiceiro de Cantão.

Embarcado num veleiro

no porto de Macau.

Cartas com obreias.

Correspondentes antigos.

Cartuchos de confeitos de ouro.

Alforrias de escravos. 
Bodas de meu avô.

Bragal da minha avó.

Roda e tear, marafundas e repolegos.

Coisas do passado...

E - dizia minha bisavó -

tudo se deu como o contado.

Cora Coralina. Poemas dos Becos de Goiás e Estórias mais; - 23ª edição - São Paulo: Global, 2014 


\section{Anexo II: \\ NOTA \\ De como acabou, em Goiás, o castigo dos cacos quebrados no pescoço}

Foi com a morte da menina Jesuína. Era minha bisavó quem contava. Eu era pequena, ouvia e chorava. Me parecia eu mesma, a pequena da história.

Havia na cidade, contemporânea de minha bisavó, uma tal de dona Jesuína, senhora apatacada, dona de Teres-Haveres. Sempre encontrada nos velórios, muito solidária com a morte e com os vivos, ali permanecia invariavelmente até que os galos amiudassem. Tinha seus escravos de serviço e de aluguel, entre estes a escrava de dentro, de nome Prudência. Está no completo. Nas medidas exigentes do tempo. Sem preço. Deu a sua sinhá vários crioulos de valor que mais enricaram a velha dona. No fim veio aquela que tomaria o nome de Rola, afilhada e alforriada na Pia, o que era legal e usado no tempo. Rola teve casamento de capela fechada dizendo sua condição de moça-virgem.

Não tardou muito por essas e tais razões e sofismas, a se representar hética. Diziam: gálico do marido. Certo que depois de várias vomitações de sangue (hemoptises) que a levaram, deixou no mundo uma menina que a madrinha batizou também com seu próprio nome - Jesuína. A pequena, um fiapo de gente, veio para os braços da avó, trazida pela sinhá madrinha. Filha de mãe hética, débil, franzina, foi espigando devagarinho, imperceptivelmente, mamando no seio fecundo da negra avó que fez renascer o seu veio de leite por amor à neta. Certo, ia vivendo e crescendo dentro das regras do tempo velho. Nem escrava, nem forra. Meio a meio em boa disciplina.

Não era má, dona Jesuína, antes de boa justiça, madurona, severa, experiente.

Jesuína encostou-se afinal nos dez anos. Magrinha, grande olhos de espanto para a vida. Medrosa, obediente, agarrada a sua regalia uma boneca de pano que a madrinha teve a bondade de consentir.

Em qualquer pequena falta, a ameaça: "olha que eu tomo a boneca..." A menina apertava a bruxa no peito magro e se espiritava. 
Tinha algumas obrigações. Varria a casa, apanhava o cisco. Lavava umas tantas peças de louça e aprendia a ler. Tinha, nas vagas, sua carta de a-bê-cê, sentadinha no canto, tomando propósito.

Dormia numa esteirinha nos pés da grande marquesa de sobrecéu armado, da madrinha. Velhos pedaços de forro eram a coberta.

A obrigação: de pela manhã descerrar os tampos da janela, apagar a lamparina de azeite, chegar as chinelas nos pés reumáticos da madrinha, apresentar o urinol para os alívios da velha. Regra certa, imutável, consolidada, sem variação. Um chamado - Jesuína, a menina de pé, pedindo a bênção, praticando a obediência.

Aconteceu que um dia a tampa da terrina escapuliu das mãos da menina e escacou. Foi um escarcéu. Dona Jesuína estremeceu em severidades visíveis, e se conteve: "que não fizesse outra...".

Teria contudo de ser castigada, exemplada: um colar de cacos quebrados no pescoço e a bruxa consumida. Proibido chorar. Assim era e assim foi. Coisas do tempo velho. A cacaria serrilhada, amarrada a espaço num cordão encerado, ficava como humilhante castigo exemplar, de que todos se riam até que num longínquo dia-santo alguém se lembrasse de punir por aquela retirada.

No caso da menina continuava. Dormia e acordava com seu colar de pedaços desiguais e serrilhados de jeito a permanência. Tinha nas casas gente afeita a essas artes, elaboravam com simetria e gosto maldoso. Naqueles tempos refastados, qualquer castigo agradava e eram agravados com motes e aprovação convincentes.

Aconteceu que, naquela noite, dona Jesuína foi acordada com uns resmungos, gemidos, quase, vindos da esteirinha. Ralhou: "Aquieta, muleca, deixa a gente durmi..."

Tudo aquietou e a noite continuou seu giro no espaço e no tempo. Na alcova, o círculo amarelo da velha lamparina de azeite. Os quadros de santos imóveis nas paredes. Depois novo resmungo, uns gemidinhos, coisa de menor.

De novo, a velha da sua alta marquesa: "vira de banda, menina, isso é pisadeira, não vai mijá na esteira..."

O silêncio se fez. A velha voltou ao sono, acordou nas horas. "Jesuína, Jesuína." Nada de resposta. Comentou: "pois é, enche o bucho, vem pisadeira, não deixa durmi, e de manhã ferra no sono". 
A lamparina, sua luz escassa e amarelada em meia claridade. Dona Jesuína desceu as pernas, os pés deram um molhado visguento e frio. - "Pois é, enche a barriga e ainda suja na esteira..." Jesuína, gritou forte. No silêncio da alcova os santos veneráveis, frios, hieráticos. A velha abriu a janela num repelão.

Abaixou, sacudiu a menina. Recuou. A criança estava fria, endurecida e morta. A esteirinha encharcada. Durante a noite, no sono, uma aresta mais viva de um dos cacos serrilhados tinha cortado uma veiazinha do seu pescoço, e por ali tinha no correr da noite esvaído seu pouco sangue e ela estava enrodilhada, imobilizada para sempre.

A notícia correu. As amigas de dona Jesu vieram e deram pêsames, justificando: foi a mãe que veio buscar a filha.

Foi assim, com o sacrifício da menina Jesuína, desaparecendo em Goiás o castigo exemplar do colar de cacos quebrados no pescoço. Quando chegou a minha vez já era só um caco.

No meu sono de criança, tinha a sensação de uma sombra debruçada sobre mim. Era minha bisavó ajeitando o caco, tirando para fora da coberta.

Não fosse acontecer com Aninha, o que acontecera com a menina Jesuína, cria da dona Jesu.

Cora Coralina. O Prato Azul-Pombinho; Ilustrações Lúcia Hiratsuka. - 4ª edição - São Paulo: Global, 2011. 
Milho...

Punhado plantado nos quintais.

Talhões fechados pelas roças.

Entremeado nas lavouras,

Baliza marcante nas divisas.

Milho verde. Milho seco.

Bem granado, cor de ouro.

Alvo. Às vezes varia,

- espiga roxa, vermelha, salpintada.

Milho virado, maduro, onde o feijão enrama

Milho quebrado, debulhado

na festa das colheitas anuais.

Bandeira de milho levada para os montes, largada pelas roças.

Bandeiras esquecidas na fartura.

Respiga descuidada

dos pássaros e dos bichos.

Milho empaiolado...

abastança tranquila

do rato,

do caruncho,

do cupim.

Palha de milho para o colchão.

Jogada pelos pastos.

Mascada pelo gado.

Trançada em fundos de cadeiras.

Queimada nas coivaras.

Leve mortalha de cigarros.

Balaio de milho trocado com o vizinho

no tempo da planta.

"- Não se planta, nos sítios, semente da mesma terra".

Ventos rondando, redemoinhando.

Ventos de outubro.

Tempo mudado. Revoo de saúva.

Trovão surdo, tropeiro.

Na vazante do brejo, no lameiro,

o sapo-fole, o sapo-ferreiro, o sapo-cachorro.

Acauã de madrugada

marcando o tempo, chamando chuva.

Roça nova encoivarada,

começo de brotação. 
Roça velha destocada.

Palhada batida, riscada de arado.

Barrufo de chuva.

Cheiro de terra; cheiro de mato,

Terra molhada, Terra saroia.

Noite chuvada, relampeada.

Dia sombrio. Tempo mudado, dando sinais.

Observatório: lua virada. Lua pendida...

Circo amarelo, distanciado,

marcando chuva.

Calendário, Astronomia do lavrador.

Planta de milho na lua-nova.

Sistema velho colonial.

Planta de enxada.

Seis grãos na cova,

quatro na regra, dois de quebra.

Terra arrastada com o pé,

pisada, incalcada, mode os bichos.

Lanceado certo-cabo-da-enxada..

Vai, vem... sobe, desce...

terra molhada, terra saroia...

- Seis grãos na cova; quatro na regra, dois de quebra.

Sobe. Desce...

Camisa de riscado, calça de mescla

Vai, vem...

golpeando a terra, o plantador.

Na sombra da moita,

na volta do toco - o ancorote - d'água.

Cavador de milho, que está fazendo?

A que milênios vem você plantando.

Capanga de grãos dourados a tiracolo.

Crente da Terra, Sacerdote da terra.

Pai da Terra.

Filho da Terra.

Ascendente da Terra.

Descendente da Terra.

Ele, mesmo, Terra.

Planta com fé religiosa.

Planta sozinho, silencioso.

Cava e planta.

Gestos pretéritos, imemoriais.

Oferta remota; patriarcal.

Liturgia milenária.

Ritual de paz. 
Em qualquer parte da Terra

um homem estará sempre plantando,

recriando a Vida.

Recomeçando o Mundo.

Milho plantado; dormindo no chão, aconchegados

seis grãos na cova.

Quatro na regra, dois de quebra.

Vida inerte que a terra vai multiplicar

Evém a perseguição:

o bichinho anônimo que espia, pressente.

A formiga-cortadeira - quem-quem.

A ratinha do chão, exploradeira.

A rosca vigilante na rodilha,

O passo-preto vagabundo, galhofeiro,

vaiando, sorrindo ...

aos gritos arrancando, mal aponta.

O cupim clandestino

roendo, minando,

só de ruindade.

E o milho realiza o milagre genético de nascer.

Germina. Vence os inimigos.

Aponta aos milhares.

- Seis grãos na cova.

- Quatro na regra, dois de quebra,

Um canudinho enrolado.

Amarelo-pálido,

frágil, dourado, se levanta.

Cria sustância.

Passa a verde.

Liberta-se. Enraíza.

Abre folhas espaldeiradas.

Encorpa. Encana. Disciplina, com os poderes de Deus.

Jesus e São João

desceram de noite na roça,

botaram a bênção no milho.

$E$ veio com eles

uma chuva maneira, criadeira, fininha,

uma chuva velhinha,

de cabelos brancos,

abençoando

a infância do milho.

O mato vem vindo junto.

Sementeira. 
As pragas todas, conluiadas.

Carrapicho. Amargoso. Picão.

Marianinha. Caruru-de-espinho.

Pé-de-galinha. Colchão.

Alcança, não alcança.

Competição.

Pac... Pac... Pac...

a enxada canta.

Bota o mato abaixo.

arrasta uma terrinha para o pé da planta.

"- Carpa bem feita vale por duas..."

quando pode. Quando não... sarobeia.

Chega terra. O milho avoa.

Cresce na vista dos olhos.

Aumenta de dia. Pula de noite.

Verde. Entonado, disciplinado, sadio.

Agora...

A lagarta da folha, lagarta rendeira...

Quem é que vê?

Faz renda da folha no quieto da noite.

Dorme de dia no olho da planta.

Gorda. Barriguda. Cheia.

Expurgo... nada... força da lua...

Chovendo acaba - a Deus querê.

"O mio tá bonito..."

"Vai sê bão o tempo pras lavoras todas..."

"O mio tá marcando..."

Condicionando o futuro:

"O roçado de seu Féli tá qui fais gosto...

Um refrigério!"

"O mio lá tá verde qui chega a s’tar azur..."

Conversam vizinhos e compadres.

Milho crescendo, garfando,

esporando nas defesas.

Milho embandeirado.

Embalado pelo vento.

"Do chão ao pendão, 60 dias vão".

Passou aguaceiro, pé-de-vento.

"O milho acamou..."

"Perdido?"... "Nada...

Ele arriba com os poderes de Deus..."

E arribou mesmo, garboso, empertigado, vertical. 
No cenário vegetal

um engraçado boneco de frangalhos

sobre-eleva, vigilante.

Alegria verde dos periquitos gritadores...

Bandos em sequência... Evolução...

Pouso... retrocesso.

Manobras em conjunto.

Desfeita formação.

Roedores grazinando, se fartando,

foliando, vaiando

os ingênuos espantalhos.

"Jesus e São João

andaram de noite passeando na lavoura

e botaram a bênção no milho."

Fala assim gente de roça e fala certo.

Pois não está lá na taipa do rancho

o quadro deles, passeando dentro dos trigais?

Analogias... Coerências.

Milho embandeirado

bonecando em gestação.

- Senhor!... Como a roça cheira bem!

Flor de milho, travessa e festiva.

Flor feminina, esvoaçante, faceira.

Flor masculina - lúbrica, desgraciosa.

Bonecas de milho túrgidas,

negaceando, se mostrando vaidosas.

Túnicas, sobretúnicas...

saias, sobressaias...

Anáguas... camisas verdes.

Cabelos verdes...

Cabeleiras soltas, lavadas, despenteadas...

- O milharal é desfile de beleza vegetal.

Cabeleiras vermelhas, bastas, onduladas.

Cabelos prateados, verde-gaios.

Cabelos roxos, lisos, encrespados.

Destrançados.

Cabelos compridos, curtos,

queimados, despenteados...

Xampu de chuvas...

Flagrâncias novas no milharal.

- Senhor, como a roça cheira bem!...

As bandeiras altaneiras

vão-se abrindo em formação. 
Pendões ao vento.

Extravasão da libido vegetal.

procissão fálica, pagã.

Um sentido genésico domina o milharal.

Flor masculina erótica, libidinosa,

polinizando, fecundando

a florada adolescente das bonecas.

Boneca de milho, vestida de palha...

Sete cenários defendem o grão.

Gordas, esguias, delgadas, alongadas.

Cheias, fecundadas.

Cabelos soltos excitantes.

Vestidas de palha.

Sete cenários defendem o grão.

Bonecas verdes, vestidas de noiva.

Afrodisíacas, nupciais...

De permeio algumas virgens loucas...

Descuidadas. Desprovidas.

Espigas falhadas. Fanadas. Macheadas.

Cabelos verdes. Cabelos brancos.

Vermelhos-amarelos-roxos, requeimados...

E o pólen dos pendões fertilizando...

Uma fragrância quente, sexual

invade num espasmo o milharal.

A boneca fecundada vira espiga.

Amortece a grande exaltação.

Já não importam as verdes cabeleiras rebeladas.

A espiga cheia salta da haste.

O pendão fálico vira ressecado, esmorecido,

no sagrado rito da fecundação.

Tons maduros de amarelo.

Tudo se volta para a terra-mãe.

O tronco seco é um suporte, agora,

onde o feijão verde trança, enrama, enflora.

Montes de milho novo, esquecidos,

marcando claros no verde que domina a roça.

Bandeiras perdidas na fartura das colheitas.

Bandeiras largadas, restolhadas.

E os bandos de passo-pretos galhofeiros

gritam e cantam na respiga das palhadas.

"Não andeis a respigar" - diz o preceito bíblico.

O grão que cai é o direito da terra.

A espiga perdida - pertence às aves 
que têm seus ninhos e filhotes a cuidar.

Basta para ti, lavrador,

o monte alto e a tulha cheia.

Deixa a respiga para os que não plantam nem colhem.

- O pobrezinho que passa.

- Os bichos da terra e os pássaros do céu.

Cora Coralina. Poema do Milho; Ilustrações Lélis. - 3ª Edição - São Paulo: Global, 2011. 


\section{Anexo IV: \\ ORAÇÃO DO MILHO \\ Introdução ao Poema do Milho}

Senhor, nada valho.

Sou a planta humilde dos quintais pequenos e das lavouras pobres.

Meu grão, perdido por acaso, nasce e cresce na terra descuidada.

Ponho folhas e haste, e se me ajudares Senhor, mesmo planta de acaso, solitária, dou espigas e devolvo em muitos grãos, o grão perdido inicial, salvo por milagre, que a terra fecundou.

Sou a planta primária da lavoura.

Não me pertence a hierarquia tradicional do trigo e de mim, não se faz o pão alvo, universal.

O Justo não me consagrou Pão da Vida, nem lugar me foi dado nos altares.

Sou apenas o alimento forte e substancial dos que trabalham a terra, onde não vinga o trigo nobre. Sou de origem obscura e de ascendência pobre, alimento de rústicos e animais do jugo.

Quando os deuses da Hélade corriam pelos bosques, coroados de rosas e de espigas, quando os hebreus iam em longas caravanas buscar na terra do Egito o trigo dos faraós, quando Rute respigava cantando nas searas de Booz e Jesus abençoava os trigais maduros, eu era apenas o bró nativo das tabas ameríndias.

Fui o angu pesado e constante do escravo na exaustão do eito.

Sou a broa grosseira e modesta do pequeno sitiante.

Sou a farinha econômica do proletário.

Sou a polenta do imigrante e a miga dos que começam a vida em terra estranha.

Alimento dos porcos e do triste mu de carga.

O que me planta não levanta comércio, nem avantaja dinheiro.

Sou apenas a fartura generosa e despreocupada dos paióis.

Sou o cocho abastecido donde rumina o gado.

Sou o canto festivo dos galos na glória do dia que amanhece.

Sou o cacarejo alegre das poedeiras à volta dos seus ninhos.

Sou a pobreza vegetal, agradecida a Vós, Senhor, que me fizeste necessário e humilde

Sou o milho.

Cora Coralina. Poema do Milho; Ilustrações Lélis. - 3ㅡdição - São Paulo: Global, 2011. 


\section{Anexo V:}

\section{Escova}

Eu tinha vontade de fazer como os dois homens que vi sentados na terra escovando osso. No começo achei que aqueles homens não batiam bem. Porque ficavam sentados na terra o dia inteiro escovando osso. Depois aprendi que aqueles homens eram arqueólogos. Que eles faziam o serviço de escovar osso por amor. E que eles queriam encontrar nos ossos vestígios de antigas civilizações que estariam enterradas por séculos naquele chão. Logo pensei de escovar palavras. Porque eu havia lido em algum lugar que as palavras eram conchas de clamores antigos. Eu queria ir atrás dos clamores antigos que estariam guardados dentro das palavras. Eu já sabia também que as palavras possuem no corpo muitas oralidades remontadas e muitas significâncias remontadas. Eu queria então escovar as palavras para escutar o primeiro esgar de cada uma. Para escutar os primeiros sons, mesmo que ainda bígrafos. Comecei a fazer isso sentado em minha escrivaninha. Passava horas inteiras, dias inteiros fechado no quarto, trancado, a escovar palavras. Logo a turma perguntou: o que eu fazia o dia inteiro trancado naquele quarto? Eu respondi a eles, meio entresonhado, que eu estava escovando palavras. Eles achavam que eu não batia bem. Então eu joguei a escova fora.

Manoel de Barros. Memórias inventadas: as infâncias de Manoel de Barros. São Paulo: Editora Planeta do Brasil, página 19, 2008. 


\section{Anexo VI:}

\section{Desobjeto}

O menino que era esquerdo viu no meio do quintal um pente. O pente estava próximo de não ser mais um pente. Estaria mais perto de ser uma folha dentada. Dentada um tanto que já se havia incluído no chão que nem uma pedra um caramujo um sapo. Era alguma coisa nova o pente. O chão teria comido logo um pouco de seus dentes. Camadas de areia e formigas roeram seu organismo. Se é que um pente tem organismo.

O fato é que o pente estava sem costela. Não se poderia mais dizer se aquela coisa fora um pente ou um leque. As cores a chifre de que fora feito o pente deram lugar a um esverdeado a musgo. Acho que os bichos do lugar mijavam muito naquele desobjeto. $O$ fato é que o poente perdera a sua personalidade. Estava encostado às raízes de uma árvore e não servia mais nem para pentear macaco. O menino que era esquerdo e tinha cacoete pra poeta, justamente ele enxergara o pente naquele estado terminal. E o menino deu para imaginar que o pente, naquele estado, já estaria incorporado à natureza como um rio, um osso, um lagarto. Eu acho que as árvores colaboravam na solidão daquele pente.

Manoel de Barros. Memórias inventadas: as infâncias de Manoel de Barros. São Paulo: Editora Planeta do Brasil, página 25, 2008. 


\section{Anexo VII:}

\section{Latas}

Estas latas têm que perder, por primeiro, todos os ranços (e artifícios) da indústria que as produziu. Segundamente, elas têm que adoecer na terra. Adoecer de ferrugem e casca. Finalmente, só depois de trinta e quatro anos elas merecerão de ser chão. Esse desmanche em natureza é doloroso e necessário se elas quiserem fazer parte da sociedade dos vermes. Depois desse desmanche em natureza, as latas podem até namorar com as borboletas. Isso é muito comum. Diferentes de nós, as latas com o tempo rejuvenescem, se jogadas na terra. Chegam quase até de serem pousadas de caracóis. Elas sabem, as latas, que precisam chegar ao estágio de uma parede suja. Só assim serão procuradas pelos caracóis. Sabem muito bem, estas latas, que precisam da intimidade com o lodo obsceno das moscas. Ainda elas precisam de pensar em ter raízes. Para que possam obter estames e pistilos. A fim de que um dia elas possam se oferecer às abelhas. Elas precisam de ser um ensaio de árvore a fim de comungar a natureza. O destino das latas pode também ser pedra. Elas hão de ser cobertas de limo e musgo. As latas precisam ganhar o prêmio de dar flores. Elas têm de participar dos passarinhos. Eu sempre desejei que as minhas latas tivessem aptidão para passarinhos. Como os rios têm, como as árvores têm. Elas ficam muito orgulhosas quando passam do estágio de chutadas nas ruas para o estágio de poesia. Acho esse orgulho das latas muito justificável e até louvável.

Manoel de Barros. Memórias inventadas: as infâncias de Manoel de Barros. São Paulo: Editora Planeta do Brasil, página 55, 2008. 


\section{Anexo VIII:}

\section{Achadouros}

Acho que o quintal onde a gente brincou é maior do que a cidade. A gente só descobre depois de grande. A gente descobre que o tamanho das coisas há que ser medido pela intimidade que temos com as coisas. Há de ser como acontece com o amor. Assim, as pedrinhas do nosso quintal são sempre maiores do que as outras pedras do mundo. Justo pelo motivo da intimidade. Mas o que eu queria dizer sobre nosso quintal é outra coisa. Aquilo que a negra pombada, remanescente de escravos do Recife, nos contava. Pombada contava aos meninos de Corumbá sobre achadouros. Que eram buracos que os holandeses, na fuga apressada do Brasil, faziam nos seus quintais para esconder suas moedas de ouro, dentro de grandes baús de couro. Os baús ficavam cheios de moedas dentro daqueles buracos. Mas eu estava a pensar em achadouros de infâncias. Se a gente cavar um buraco ao pé da goiabeira do quintal, lá estará um guri ensaiando subir na goiabeira. Se a gente cavar um buraco ao pé do galinheiro, lá estará um guri tentando agarrar no rabo de uma lagartixa. Sou hoje um caçador de achadouros de infância. Vou meio dementado e enxada às costas a cavar no meu quintal vestígios dos meninos que fomos. Hoje encontrei um baú cheio de punhetas.

Manoel de Barros. Memórias inventadas: as infâncias de Manoel de Barros. São Paulo: Editora Planeta do Brasil, página 58, 2008. 


\section{Anexo IX:}

\section{Sobre sucatas}

Isto porque a gente foi criada em um lugar onde não tinha brinquedo fabricado. Isto porque a gente havia que fabricar os nossos brinquedos: eram boizinhos de osso, bolas de meia, automóveis de lata. Também a gente fazia de conta que sapo é boi de cela e viajava de sapo. Outra era ouvir nas conchas as origens do mundo. Estranhei muito quando, mais tarde, precisei de morar na cidade. Na cidade, um dia, contei para minha mãe que vira na Praça um homem montando no cavalo de pedra a mostrar uma faca comprida para o alto. Minha mãe corrigiu que não era uma faca, era uma espada. E que o homem era um herói da nossa história. Claro que eu não tinha educação de cidade para saber que herói era um homem sentado num cavalo de pedra. Eles eram pessoas antigas da história que algum dia defenderam a nossa Pátria. Para mim aqueles homens em cima da pedra eram sucata. Seriam sucata da história. Porque eu achava que uma vez no vento esses homens seriam como trastes, como qualquer pedaço de camisa nos ventos. Eu me lembrava dos espantalhos vestidos com as minhas camisas. O mundo era um pedaço complicado para o menino que viera da roça. Não vi nenhuma coisa mais bonita na cidade do que um passarinho. Vi que tudo que o homem fabrica vira sucata: bicicleta, avião, automóvel. Só o que não vira sucata é a ave, árvore, rã, pedra. Até nave espacial vira sucata. Agora eu penso uma garça branca de brejo ser mais linda que uma nave espacial. Peço desculpas por cometer essa verdade.

Manoel de Barros. Memórias inventadas: as infâncias de Manoel de Barros. São Paulo: Editora Planeta do Brasil, página 61, 2008. 


\section{Anexo X:}

\section{Pretexto}

O que eu gostaria de fazer é um livro sobre nada. Foi o que escreveu Flaubert a uma sua amiga em 1852. Li nas Cartas exemplares organizadas por Duda Machado. Ali se vê que o nada de Flaubert não seria o nada existencial, o nada metafísico. Ele queria o livro que não tem quase tema e se sustente só pelo estilo. Mas o nada de meu livro é nada mesmo. É coisa nenhuma por escrito: um alarme para o silêncio, um abridor de amanhecer, pessoa apropriada para pedras, o parafuso de veludo, etc etc. o que eu queria era fazer brinquedos com as palavras. Fazer coisas desúteis. $O$ nada mesmo. Tudo que use o abandono por dentro e por fora.

Manoel de Barros. Livro sobre Nada. - 9ª edição - Rio de Janeiro: Record, página 07, 2001. 


\section{Anexo XI:}

\section{Todas as Vidas}

Vive dentro de mim

uma cabocla velha

de mau-olhado,

acocorada ao pé do borralho,

olhando para o fogo.

Benze quebranto.

Bota feitiço...

Ogum. Orixá.

Macumba, terreiro.

Ogã, pai-de-santo...

Vive dentro de mim

a lavadeira do Rio Vermelho.

Seu cheiro gostoso

d'água e sabão.

Rodilha de pano.

Trouxa de roupa,

pedra de anil.

Sua coroa verde de são-caetano.

Vive dentro de mim

a mulher cozinheira.

Pimenta e cebola.

Quitute bem feito.

Panela de barro.

Taipa de lenha.

Cozinha antiga

toda pretinha.

Bem cacheada de picumã. 
Pedra pontuda.

Cumbuco de coco.

Pisando alho-sal.

Vive dentro de mim

a mulher do povo.

Bem proletária.

Bem linguaruda,

desabusada, sem preconceitos,

de casca-grossa,

de chinelinha,

e filharada.

Vive dentro de mim

a mulher roceira.

- Enxerto de terra,

meio casmurra.

Trabalhadeira.

Madrugadeira.

Analfabeta.

De pé no chão.

Bem parideira.

Bem criadeira.

Seus doze filhos,

Seus vinte netos.

Vive dentro de mim

a mulher da vida.

Minha irmãzinha...

tão desprezada,

tão murmurada...

Fingindo ser alegre seu triste fado.

Todas as vidas dentro de mim: 
Na minha vida -

a vida mera das obscuras.

Cora Coralina. Poemas dos becos de Goiás e estórias mais. - 23ª edição - São Paulo: Global, 2014, p. 31-33. 


\section{Anexo XII:}

\section{A Gleba me Transfigura}

Sinto que sou a abelha no seu artesanato.

Meus versos têm cheiro dos matos, dos bois e dos currais.

Eu vivo no terreiro dos sítios e das fazendas primitivas.

Amo a terra de um místico amor consagrado, num esponsal sublimado, procriador e fecundo.

Sinto seus trabalhadores rudes e obscuros,

suas aspirações inalcançadas, apreensões e desenganos.

Plantei e colhi pelas suas mãos calosas

e tão mal remuneradas.

Participamos receosos do sol e da chuva em desencontro, nas lavouras carecidas.

Acompanhamos atentos, trovões longínquos e o riscar

de relâmpagos no escuro da noite, irmanados no regozijo

das formações escuras e pejadas no espaço

e o refrigério da chuva nas roças plantadas, nos pastos maduros

e nas cabeceiras das aguadas.

Minha identificação profunda e amorosa

com a terra e com os que nela trabalham.

A gleba me transfigura. Dentro da gleba,

ouvindo o mugido da vacada, o mééé dos bezerros,

o roncar e focinhar dos porcos, o cantar dos galos,

o cacarejar das poedeiras, o latir dos cães,

eu me identifico.

Sou árvore, sou tronco, sou raiz, sou folha,

sou graveto, sou mato, sou paiol

e sou a velha trilha de barro.

Pela minha voz cantam todos os pássaros, piam as cobras

e coaxam as rãs, mugem todas as boiadas que vão pelas estradas. 
Sou a espiga e o grão que retornam à terra.

Minha pena (esferográfica) é a enxada que vai cavando,

é o arado milenário que sulca.

Meus versos têm relances de enxada, gume de foice

e peso de machado.

Cheiro de currais e gosto de terra.

Eu me procuro no passado.

Procuro a mulher sitiante, neta de sesmeiros.

Procuro Aninha, a inzoneira que conversava com as formigas,

e seu comadrio com o ninho das rolinhas.

Onde está Aninha, a inzoneira,

menina do banco das mais atrasadas da escola de Mestra Silvina...

Onde ficaram os bancos e as velhas cartilhas da minha escola primária?

Minha mestra... Minha mestra... beijo-Ihe as mãos,

tão pobre!...

Meus velhos colegas, um a um foram partindo, raleando a fileira...

Aninha, a sobrevivente, sua escrita pesada, assentada

nas pedras da nossa cidade...

Amo a terra de um velho amor consagrado

através de gerações de avós rústicos, encartados

nas minas e na terra latifundiária, sesmeiros.

A gleba está dentro de mim. Eu sou a terra.

Identificada com seus homens rudes e obscuros,

enxadeiros, machadeiros e boiadeiros, peões e moradores.

Seus trabalhos rotineiros, suas limitadas aspirações.

Partilhei com eles de esperança e desenganos.

Juntos, rezamos pela chuva e pelo sol.

Assuntamos de um trovão longínquo, de um fuzilar

de relâmpagos, de um sol fulgurante e desesperador,

abatendo as lavouras carecidas.

Festejamos a formação no espaço de grandes nuvens escuras 
e pejadas para a salvação das lavouras a se perderem.

Plantei pelas suas enxadas e suas mãos calosas.

Colhi pelo seu esforço e constância.

Minha identificação com a gleba e com sua gente.

Mulher da roça eu o sou. Mulher operária, doceira, abelha no seu artesanato, boa cozinheira, boa lavadeira.

A gleba me transfigura, sou semente, sou pedra.

Pela minha voz cantam todos os pássaros do mundo.

Sou a cigarra cantadeira de um longo estio que se chama Vida.

Sou a formiga incansável, diligente, compondo seus abastos.

Em mim a planta renasce e floresce, sementeia e sobrevive.

Sou a espiga e o grão fecundo que retornam à terra.

Minha pena é a enxada do plantador, é o arado que vai sulcando para a colheita das gerações.

Eu sou o velho paiol e a velha tulha roceira.

Eu sou a terra milenária, eu venho de milênios.

Eu sou a mulher mais antiga do mundo, plantada e fecundada no ventre escuro da terra.

Cora Coralina. Vintém de Cobre: meias confissões de Aninha. - 10ª edição - São Paulo: Global, 2013, p. 108-111. 


\section{Anexo XIII:}

\section{Sou Raiz}

Sou raiz, e vou caminhando

sobre as minhas raízes tribais.

Velhas jardineiras do passado ...

Condutores e cobradores, vós me levastes de mistura com os pequenos e iletrados, pobres e remendados ...

Destes-me o nível dos humildes em tantas lições de vida.

Passante das estradas rodageiras, boiadeiros e comissários, aqui fala a velha rapsoda.

Escuto na distância o sonido augusto do berrante que marca o compasso das manadas que vão pelas estradas.

O mugido, o berro, o chamado da querência, a aguada, o barreiro salitrado, a solta, o curral, a porteira, a tronqueira, o cocho, o moirão, a salga, o ferro de marcar, rubro, esbraseado. A castração impiedosa.

Eu sou a gleba e nada mais pretendo ser.

Mulher primária, roceira, operária, afeita à cozinha, ao curral, ao coalho, ao barreleiro, ao tacho.

Seguro sempre nas mãos cansadas a velha candeia de azeite veletudinária e vitalícia do passado.

Viajei nas velhas e valentes jardineiras do interior roceiro, suas estradas de terra, lameiros e atoleiros, seus heróicos e anônimos condutores e cobradores, práticos, sabidos daqueles motores desgastados, molas e lataria rangentes.

Santos milagreiros eram eles. Onde estarão?

Viajei de par com os humildes que tanto me ensinaram.

Viajantes das velhas jardineiras, meus vizinhos das estradas viajeiras ...

Meus trabalhadores: Manoel Rosa, José Dias, Paulo, Manoel, 
João, Mato Grosso, plantadores e enxadeiros, meus vizinhos sitiantes, onde andarão eles?

Andradina, Castilho, Jaboticabal, comissários e boiadeiros, tangerinos, esta página é toda de vocês.

Fala de longe a velha rapsoda.

Cora Coralina. Vintém de Cobre: meias confissões de Aninha. - 10ª edição - São Paulo: Global, 2013, p. 108-111. 


\section{Anexo XIV:}

\section{I - Protocolo Vegetal}

Trata de episódio que veio a possibilitar a descoberta de um caderno de poemas

Prenderam na rua um homem que entrara na prática do limo

lista dos objetos apreendidos no armário gavetas buracos de parede, pela ordem: 3 bobinas enferrujadas 1 rolo de barbante 8 armações de guarda-chuva 1 boi de pau 1 lavadeira renga de zinco (escultura inacabada) 1 rosto de boneca metade carbonizado - onde se achava pregado um caracol com a sua semente viva 3 correntes de latão 1 caixa de papelão contendo pregos ruelas zíperes e diversas cascas de cigarras estouradas no verão 1 caneco de beber água 1 boneco de pano de 50 centímetros de altura com inscrições nas costas "O FANTASMA DE OLHOS COSTURADOS" 2 senhoras da zona (esculturas em mangue) 29 folhas de caderno com escritos variados sob os títulos abaixo:

$$
\begin{aligned}
& \text { a - } 29 \text { escritos para conhecimento do chão através de } \\
& \text { São Francisco de Assis } \\
& \text { b - protocolo vegetal } \\
& \text { c - retrato do artista quando coisa } \\
& \text { d - a criatura sem o criador } \\
& \text { e - você é um homem ou um abridor de lata? }
\end{aligned}
$$

e mais os seguintes pertences de uso pessoal:

$$
\begin{aligned}
& \text { o pneu } \\
& \text { o pente }
\end{aligned}
$$


o chapéu

a muleta

o relógio de pulso

a caneta

o suspensório

o capote

a bicicleta

o garfo

a corda de enforcar

o livro maldito

a máquina

o amuleto

o bilboquê

o abridor de lata

o escapulário

0 anel

o travesseiro

o sapo seco

a bengala

o sabugo

o botão

o menino tocador de urubu

o retrato da esposa na jaula

e a tela

2.

Descrição da tela pelo Dr. Francisco Rodrigues de Miranda, amigo do preso

o artista recolhe neste quadro seus companheiros pobres do chão: a lata a corda a borra vestígios de árvores etc.

realiza uma colagem de estopa arame tampinha de 
cerveja pedaços de jornal pedras e acrescenta inscrições produzidas em muros - números truncados caretas pênis coxas (2) e 1 aranha febril

tudo muito manchado de pobreza e miséria que se não engana é da cor encardida entre amarelo

e gosma

3.

Seria o homem do Parque?

o homem tinha 40 anos de líquenes no Parque

era forte de ave

gafanhotos usavam sua boca

quase sempre nos intervalos para 0 almoço

era acometido de lodo

à noite seria carregado por formigas até as bordas de um lago

madrugada contraía orvalho nas escamas e na

marmita

4. 
São Paulo, compadre do preso, a título de esclarecimento à Polícia

para começar ninguém jamais garantiu que coisa era aquele bicho

o mal-traçado?

o tritão dorminhoco?

o irmão desaparecido de Chopin?

o homem de borracha?

conheci-o

em seu escritório

jogando bilboquê

era sempre arrastado para lugares com musgo

por meio de ser árvore podia adivinhar se a terra era fêmea e dava sapos

via o mundo como a pequena rã vê a manhã de dentro de uma pedra

pela delicadeza de muitos anos ter se agachado nas ruas para apanhar detritos - compreende o restolho

a esse tempo lê Marx

tem mil anos

tudo que vem da terra para ele sabe a lesma

é descoberto dentro de um beco

abraçado no esterco

que vão dinamitar 
antes de preso fora atacado por uma depressão mui peculiar que o fizera invadir-se pela indigência: uma depressão tão grande dentro dele como a ervinha rasteira que num terreno baldio cresce por cima de canecos emferrujados pedaços de porta arcos de barril...

era de profissão encantador de palavras

ninguém o reconheceria mais

resíduos de Raskolnikof encardiam sua boca de Pierrô muito comida de tristeza

e sujo

5.

Antissalmo por um desherói

a boca na pedra o levara a cacto

a praça o relvava de passarinhos cantando

ele tinha o dom da árvore

ele assumia o peixe em sua solidão

seu amor o levara a pedra

estava estropiado de árvore e sol

estropiado até a pedra

até o canto

estropiado no seu melhor azul

procurava-se na palavra rebotalho

por cima do lábio era só lenda

comia o ínfimo com farinha

o chão viçava no olho

cada pássaro governava sua árvore 
Deus ordenara nele a borra

o rosto e os livros com erva

andorinhas enferrujadas

Manoel de Barros. Gramática expositiva do chão. - $2^{\mathrm{a}}$ edição - São Paulo: Editora Civilização Brasileira, 1990, p. 08-20. 


\section{Anexo XV:}

\section{Obrar}

Naquele outono, de tarde, ao pé da roseira de minha

avó, eu obrei.

Minha avó não ralhou nem.

Obrar não era construir casa ou fazer obra de arte.

Esse verbo tinha um dom diferente.

Obrar seria o mesmo que cacarar.

Sei que o verbo cacarar se aplica mais a passarinhos

Os passarinhos cacaram nas folhas nos postes nas pedras do rio nas casas.

Eú só obrei no pé da roseira da minha avó.

Mas ela não ralhou nem.

Ela disse que as roseiras estavam carecendo de esterco orgânico.

E que as obras trazem força e beleza às flores.

Por isso, para ajudar, andei a fazer obra nos canteiros da horta.

Eu só queria dar força às beterrabas e aos tomates.

A vó então quis aproveitar o feito para ensinar que o cago não é uma coisa desprezível.

Eu tinha vontade de rir porque a vó contrariava os

ensinos do pai.

Minha avó, ela era transgressora.

No propósito ela me disse que até as mariposas gostavam de roçar nas obras verdes.

Entendi que obras verdes seriam aquelas feitas no dia.

Daí que também a vó me ensinou a não desprezar as coisas desprezíveis

E nem os seres desprezados.

Manoel de Barros. Memórias inventadas: as infâncias de Manoel de Barros. São Paulo: Editora Planeta do Brasil, página 22, 2008. 


\section{Anexo XVI:}

\section{O Lavador de Pedra}

A gente morava no patrimônio de Pedra Lisa. Pedra Lisa era um arruado de 13 casas e o rio por detrás. Pelo arruado passavam comitivas de boiadeiros e muitos andarilhos. Meu avô botou uma Venda no arruado. Vendia toucinho, freios, arroz, rapadura e tais. Os mantimentos que os boiadeiros compravam de passagem. Atrás da Venda estava o rio. E uma pedra que aflorava no meio do rio. Meu avô, de tardezinha, ia lavar a pedra onde as garças pousavam e cacaravam. Na pedra não crescia nem musgo. Porque o cuspe das garças tem um ácido que mata no nascedouro qualquer espécie de planta. Meu avô ganhou o desnome de Lavador de Pedra. Porque toda tarde ele ia lavar aquela pedra.

A Venda ficou no tempo abandonada. Que nem uma cama ficasse abandonada. É que os boiadeiros agora faziam atalhos por outras estradas. A Venda por isso ficou no abandono de morrer. Pelo arruado só passavam agora os andarilhos. E os andarilhos paravam sempre para uma prosa com o meu avô. E para dividir a vianda que a mãe mandava para ele. Agora o avô morava na porta da Venda, debaixo de um pé de jatobá. Dali ele via os meninos rodando arcos de barril ao modo que bicicleta. Via os meninos em cavalo de pau correndo ao modo que montados em ema. Via os meninos que jogavam bola de meia ao modo que de couro. E corriam velozes pelo arruado ao modo que tivessem comido canela de cachorro. Tudo isso mais os passarinhos e os andarilhos era a paisagem do meu avô. Chegou que ele disse uma vez: Os andarilhos, as crianças e os passarinhos têm o dom de ser poesia.

Dom de ser poesia é muito bom!

Manoel de Barros. Memórias inventadas: as infâncias de Manoel de Barros. São Paulo: Editora Planeta do Brasil, página 34, 2008. 
Anexo XVII:

\section{$O$ Menino que ganhou um rio}

Minha mãe me deu um rio.

Era dia de meu aniversário e ela não sabia

o que me presentear.

Fazia tempo que os mascates não passavam

naquele lugar esquecido.

Se o mascate passasse a minha mãe compraria

rapadura

Ou bolachinhas para me dar.

Mas como não passara o mascate, minha mãe me

deu um rio.

Era o mesmo rio que passava atrás de casa.

Eu estimei o presente mais do que fosse uma rapadura do mascate.

Meu irmão ficou magoado porque ele gostava

do rio igual aos outros.

A mãe prometeu que no aniversário do meu

irmão

Ela iria dar uma árvore para ele.

Uma que fosse coberta de pássaros.

Eu bem ouvi a promessa que a mãe fizera ao

meu irmão

E achei legal.

Os pássaros ficavam durante o dia nas margens

do meu rio

E de noite eles iriam dormir na árvore do

meu irmão.

Meu irmão me provocava assim: a minha árvore

deu flores lindas em setembro.

E o seu rio não dá flores!

Eu respondia que a árvore dele não dava

piraputanga. 
Era verdade, mas o que nos unia demais eram

os banhos nus no rio entre pássaros.

Nesse ponto nossa vida era um afago!

Manoel de Barros. Memórias inventadas: as infâncias de Manoel de Barros. São Paulo: Editora Planeta do Brasil, página 134, 2008. 


\section{Anexo XVIII:}

\section{Menina Mal-Amada}

No Passado

Tanta coisa me faltou.

Tanta coisa desejei sem alcançar.

Hoje, nada me falta,

me faltando sempre o que não tive.

Era eu uma pobre menina mal amada.

Frustrei as esperanças de minha mãe, desde o meu nascimento.

Ela esperava e desejava um filho homem, vendo meu pai doente irreversível.

Em vez, nasceu aquela que se chamaria Aninha.

Duas criaturas idosas me deram seus carinhos:

Minha bisavó e minha tia Nhorita.

Minha bisavó me acudia quando das chineladas cruéis da minha mãe.

No mais, eu devia ser, hoje reconheço, menina enjoada, enfadando as jovens da casa e elas se vingavam da minha presença aborrecida, me pirraçando, explorando meu atraso mental, me fazendo chorar e levar queixas doloridas para a mãe que perdida no seu mundo de leitura e negócios não dava atenção.

Quem punia por Aninha era mesmo minha bisavó.

Me ensinava as coisas, corrigia paciente meus mal feitos de criança e exortava minhas irmãs a me aceitarem.

Daí minha fuga para o enorme quintal onde meus sentidos foram se aguçando para as pequenas ocorrências de que não participavam minhas irmãs.

Minhas impressões foram se acumulando lentamente e eu passei a viver uma vida estranha de mentiras e realidades.

E fui marcada: menina inzoneira.

Sem saber o significado da palavra, acostumada ao tratamento ridicularizante, esta palavra me doía.

Certo foi que eu engenhava coisas, inventava convivência com cigarras, 
descia na casa das formigas, brincava de roda com elas, cantava "Senhora D. Sancha", trocava anelzinho.

Eu contava essas coisas lá dentro, ninguém compreendia.

Chamavam, mãe: vem ver Aninha...

Mãe vinha, ralhava forte.

Não queria que eu fosse para o quintal, passava a chave no portão.

Tinha medo, fosse um ramo de loucura, sendo eu filha de velho doente.

Era nesse tempo, amarela, de olhos empapuçados, lábios descorados.

Tinha boqueira, uma esfoliação entre os dedos das mãos, diziam: "Cieiro."

Minhas irmãs tinham medo que pegasse nelas.

Não me deixavam participar de seus brinquedos.

Aparecia na casa menina de fora, minha irmã mais velha passava o braço

no ombro e segredava: "Não brinca com Aninha não. Ela tem Cieiro

e pega na gente."

Eu ia atrás, batida, enxotada.

Infância... Daí meu repúdio invencível à palavra saudade, infância...

Infância... Hoje, será.

Cora Coralina. Vintém de Cobre: meias confissões de Aninha. - 10ªe edição - São Paulo: Global, 2013, p. 114-121. 